\title{
FAVORABILITY FOR URANIUM IN TERTIARY SEDIMENTARY ROCKS, SOUTHWESTERN MONTANA
}

\author{
BENDIX FIELD ENGINEERING CORPORATION \\ Grand Junction Operations \\ Grand Junction, Colorado 81501
}

October 1977

\section{BUREAU OF GEOLOGY AND MINERAL TECHNOLOGY}

\author{
PREPARED FOR THE U.S. DEPARTMENT OF ENERGY \\ GRAND JUNCTION OFFICE \\ UNDER CONTRACT NO. E(05-1)-1664
}


This report was prepared as an account of work sponsored by the United States Government. Neither the United States nor the United States Department of Energy, nor any of their employees, nor any of their contractors, subcontractors, or their employees, makes any warranty, expressed or implied, or assumes any legal liability or responsibility for the accuracy, completeness or usefulness of any information, apparatus, product or process disclosed, or represents that its use would not infringe privately owned rights. 
GJBX-56(77)

FAVORABILITY FOR URANIUM

IN TERTIARY SEDIMENTARY ROCKS, SOUTHWESTERN MONTANA

M. A. Wopat, W. E. Curry,

J. W. Robins, and D. K. Marjaniemi

\begin{abstract}
BENDIX FIELD ENGINEERING CORPORATION
Grand Junction Operations

Grand Junction, Colorado 81501
\end{abstract}

October 1977

PREPARED FOR THE U.S. DEPARTMENT OF ENERGY

GRAND JUNCTION OFFICE

UNDER CONTRACT NO. EY-76-C-13-1664 

Summary ........................... . 1

Introduction ... . . . . . . . . . . . . . . . . 2

Purpose and scope .................... . 2

Area studied . . . . . . . . . . . . . . . . . 2

General geology . . . . . . . . . . . . . . 2

Geologic setting . . . . . . . . . . . . . 2

Tertiary sedimentary rocks . . . . . . . . . . 4

Possible sources of uranium . . . . . . . . . . . 4

Methods of investigation .. . . . . . . . . . . 5

Field work .................. 5

Chemical analyses................. 5

Petrographic studies ... . . . . . . . . . 6

Subsurface studies ................ 6

Favorability evaluation ............. . 6

Acknowledgements ................... 8

Northeastern basins, by M. A. Wopat . . . . . . . . . . . 9

Western Three Forks basin . . . . . . . . . . . 9 9

Eocene and Oligocene rocks .............. 9

Favorability characteristics ........... 11

Conclusions . . . . . . . . . . . . 16

Undifferentiated Tertiary rocks . . . . . . . . . 16

Favorability characteristics .......... 16

Conclusions ................ 18 
CONTENTS (continued)

$\underline{\text { Page }}$

Northeastern basins (continued)

Eastern Three Forks basin . . . . . . . . . . . 18

Favorability characteristics . . . . . . . . . 18

Conclusions ................... 20

Boulder River basin . . . . . . . . . . . . . 20

Favorability characteristics ........... 21

Conclusions . . . . . . . . . . . . . . 21

Townsend and clarkston basins .. . . . . . . . . . 22

01igocene rocks.................. 22

Favorability characteristics .......... 22

Conclusions ................ . . 24

Miocene and Pliocene rocks ............ 25

Favorability characteristics ......... 25

Conclusions ............... 26

Helena basin.................. . . 26

Favorability characteristics .......... 26

Conclusions . . . . . . . . . . . . . . 27

Silver City basin . . . . . . . . . . . . . 28

Smith River basin . . . . . . . . . . . . . 28

Favorability characteristics . . . . . . . . 28

Conclusions . . . . . . . . . . . . . . 29

South-central basins, by J. W. Robins . . . . . . . . . . 30

Jefferson River, Beaverhead River, and

Lower Ruby River basins . . . . . . . . . . . . . . 30

Eocene and 0ligocene rocks . . . . . . . . . . 30 
CONTENTS (continued)

$\underline{\text { Page }}$

South-central basins (continued)

Favorability characteristics .......... 30

Conclusions ................ 32

Miocene and Pliocene rocks ............ 32

Favorability characteristics .......... 32

Conclusions ............... 34

Pliocene and Pleistocene rocks .......... 34

Divide Creek basin. . . . . . . . . . . . . 35

Favorability characteristics ............ 35

Conclusions ................... 35

Upper Ruby River basin . . . . . . . . . . . . 35

Eocene and oligocene rocks ............. . 36

Favorability characteristics .......... 36

Conclusions ............... 36

Miocene and Pliocene rocks . . . . . . . . . 38

Favorability characteristics .......... 38

Conclusions ................ 38

Sage Creek basin . . . . . . . . . . . . . . 38

Favorability characteristics ........... 39

Conclusions . . . . . . . . . . . . . 39

Red Rock and Centennial basins . . . . . . . . . . . 39

Grasshopper Creek, Horse Prairie, Medicine

Favorability characteristics ........... 40

Conclusions . . . . . . . . . . . . . . . 41 
CONTENTS (continued)

$\underline{\text { Page }}$

South-central basins (continued)

Muddy Creek basin . . . . . . . . . . . . . . 41

Madison River basin .................. 41

Western basins, by W. E. Curry ................ 43

Deer Lodge basin. . . . . . . . . . . . . . . 43

Favorability characteristics . . . . . . . . . 43

Conclusions . . . . . . . . . . . . . . 46

Flint Creek and Gold Creek basins . . . . . . . . . . 46

Favorability characteristics . . . . . . . . . 47

Conclusions .................. 4 47

Big Hole River and Bull Creek basins . . . . . . . . . . 48

Favorability characteristics ........... 48

Conclusions .................. . . 49

Deep Creek basin . . . . . . . . . . . . . . . 49

Wise River, Blackfoot, Douglas Creek,

Avon, Rock Creek, and Philipsburg basins . . . . . . . . . 51

Favorability characteristics . . . . . . . . 51

Conclusions . . . . . . . . . . . . . . . 51

Bitterroot basin................ 51

Favorability characteristics ............ 53

Conclusions . . . . . . . . . . . . . 55

References cited ..................... . 56

Appendix A. Descriptions of selected rock units . . . . . . . 65

Appendix B. Selected stratigraphic and lithologic data for

stratigraphic sections described in the literature . . . 117

Appendix C. Gamma-ray spectrometric analyses of rock samples . . . 121 
Appendix D. Chemical uranium analyses of selected rock samples . . 125

Appendix E. Semiquantitative emission spectroscopic analyses of selected rock samples ............. 127

Appendix F. Uranium analyses of water samples . . . . . . . . 129

Appendix G. List of petroleum test wells . . . . . . . . . . 131

Appendix H. List of water wells . . . . . . . . . . . . 133

Appendix I. Compilation of data from uranium exploration drilling projects in parts of the Three Forks, Townsend, and Upper Ruby River basins . . . . . . . . . . 135

Appendix J. Uranium occurrences described in published and open-filed reports ............. 147

Appendix K. Results of uranium disequilibrium studies . . . . . . 149 


\section{ILLUSTRATIONS}

$\underline{\text { Page }}$

Figure 1. Southwestern Montana project area and known uranium occurrences in

Tertiary basins . . . . . . . . . . . . . . . .

2. Locations and names of Tertiary basins

in the northeastern part of the study area . . . . . . 10

3. Distribution of equivalent uranium content of samples

from individual northeastern basins compared with

distributions for the south-central basins and the

western basins . . . . . . . . . . . . . . .

4. Locations and names of Tertiary basins

in the south-central part of the study area . . . . . . 31

5. Plot of equivalent uranium versus equivalent thorium

for samples from selected central basins . . . . . . .

6. Plot of equivalent uranium versus equivalent thorium

for samples from selected southern basins . . . . . . .

7. Locations and names of Tertiary basins

in the western part of the study area . . . . . . . . . . . 44

8. Plot of equivalent uranium versus equivalent thorium

for samples from the Deer Lodge, Flint Creek, and

Gold Creek basins... . . . . . . . . . . . . . .

9. Plot of equivalent uranium versus equivalent thorium

for samples from the Big Hole, Bull Creek, and Deep

Creek basins ................ 50

10. Plot of equivalent uranium versus equivalent thorium

for samples from the Wise River, Blackfoot, Douglas

Creek, Avon, and Rock Creek basins . . . . . . . . . . .

11. Plot of equivalent uranium versus equivalent thorium

for samples from the Bitterroot basin..........

Table 1. Relative favorability rating system . . . . . . . . 7

2. Summary of data from subsurface intervals of

Eocene and 01igocene rocks in the western

Three Forks basin... . . . . . . . . . . . . . .

3. Mean equivalent uranium and thorium contents

of all rock samples, by basin and age . . . . . . . . . 
ILLUSTRATIONS (continued)

Page

Plate 1. Generalized geologic map of southwestern Montana . . . . Pocket

2. Outlines of basins and location of study

localities, wells, and drill holes, southwestern In

Montana . . . . . . . . . . . . . . . . P Pocket

APPENDIX ILLUSTRATIONS

Figure I-1. Location map of uranium exploration drill

holes and study localities of part of the

Three Forks basin . . . . . . . . . . . . . . . 138

I-2. Location map of uranium exploration drill

holes, surface radioactivity anomalies, and

study localities of an area near Winston,

Townsend basin . . . . . . . . . . . . . 140

I-3. Location map of uranium exploration drill

holes, surface radioactivity anomalies, and

study localities of part of the Upper Ruby

River basin . . . . . . . . . . . . . . . 144

$\mathrm{K}-1$. Plot of chemical uranium versus equivalent

uranium for selected samples from south-

western Montana . . . . . . . . . . . . . 151

Table I-1. Uranium exploration drill holes . . . . . . . . . . 136

I-2. Subsurface radioactivity anomalies in part

of the Three Forks basin . . . . . . . . . . . . . 137

I-3. Subsurface radioactivity anomalies in an

area near Winston, Townsend basin . . . . . . . . . . . 142

I-4. Subsurface radioactivity anomalies in part

of the Upper Ruby River basin . . . . . . . . . . . . . . 143

$\mathrm{K}-1$. Distribution of samples analyzed for uranium

disequilibrium, by area and degree of

disequilibrium . . . . . . . . . . . . . 152 

Tertiary sedimentary rocks in the basins of southwestern Montana were studied to determine their favorability for potential uranium resources. Three major age groups of Tertiary rocks were studied: the Beaverhead Conglomerate, which was deposited during Late Cretaceous through early Eocene time as a result of Laramide tectonism, and two sedimentary sequences which filled the intermontane basins after the basins were formed. The older of these two basin-fill sequences is the lower Tertiary sequence, which contains rocks of late Eocene, Oligocene, and, locally, early Miocene age. The upper Tertiary sequence includes rocks of late Miocene and Pliocene age, and is separated from the lower sequence by an unconformity of middle Miocene age. of the three groups, the lower Tertiary sequence is the most favorable and the Beaverhead Conglomerate is the least favorable for potential uranium resources.

Uranium in the Tertiary sedimentary rocks was probably derived from the Boulder batholith and from silicic volcanic material. The batholith contains numerous uranium occurrences and is the most favorable plutonic source for uranium in the study area. Silicic volcanic material is incorporated in the Tertiary rocks as air-fall tuff. This tuffaceous material is abundant throughout both basin-fill sequences, and contains up to $17 \mathrm{ppm}$ equivalent uranium where it is not diluted by detrital sediments.

Subjective favorability categories of good, moderate, and poor, based on the number and type of favorable criteria present, were used to classify the rock sequences studied. Rocks judged to have good favorability for uranium deposits are (1) Eocene and Oligocene strata and undifferentiated Tertiary rocks in the western Three Forks basin and (2) Oligocene rocks in the Helena basin. Rocks having moderate favorability consist of ( 1 ) Eocene and Oligocene strata in the Jefferson River, Beaverhead River, and Lower Ruby River basins, (2) 01igocene rocks in the Townsend and Clarkston basins, (3) Miocene and Pliocene rocks in the Upper Ruby River basin, and (4) all Tertiary sedimentary formations in the eastern Three Forks basin, and in the Grasshopper Creek, Horse Prairie, Medicine Lodge Creek, Big Sheep Creek, Deer Lodge, Big Hole River, and Bull Creek basins. The following have poor favorability: (1) the Beaverhead Conglomerate in the Red Rock and Centennial basins, (2) Eocene and 01igocene rocks in the Upper Ruby River basin, (3) Miocene and Pliocene rocks in the Townsend, Clarkston, Smith River, and Divide Creek basins, (4) Miocene through Pleistocene rocks in the Jefferson River, Beaverhead River, and Lower Ruby River basins, and (5) all Tertiary sedimentary rocks in the Boulder River, Sage Creek, Muddy Creek, Madison River, Flint Creek, Gold Creek, and Bitterroot basins. No favorability rating was assigned to Tertiary rocks in the Silver City, Deep Creek, Blackfoot, Douglas Creek, Avon, Rock Creek, and Philipsburg basins because available data are insufficient to provide a basis for a meaningful evaluation. 


\section{INTRODUCTION}

This report presents results of a study of Tertiary and related sedimentary rocks in intermontane basins of southwestern Montana. The study was conducted by Bendix Field Engineering Corporation for the Grand Junction Office of the U.S. Energy Research and Development Administration (ERDA).

\section{PURPOSE AND SCOPE}

The objective of the study was to evaluate the favorability for potential uranium resources in Tertiary and related strata. Past studies indicate that the Tertiary basins in southwestern Montana are worthy of further investigation because (1) several basins contain a thick sequence of continental sedimentary rocks, (2) several basins are near possible granitic source rocks that have known uranium occurrences, and (3) some of the Montana basins are geologically similar to basins in Wyoming that are host to important sandstone-type deposits.

This study focuses on sedimentary rocks of Tertiary age, but includes some rocks of Late Cretaceous and Pleistocene ages. In some areas only a portion of the total Tertiary sedimentary section could be studied because of poor surface exposures and limited subsurface information.

\section{AREA STUDIED}

The area studied includes parts of 13 counties (Fig. 1) in southwestern Montana and contains 34 named basins which range in size from 50 to $800 \mathrm{sq} \mathrm{mi}$. The total area of the basins within the project area is about $5,000 \mathrm{sq} \mathrm{mi}$.

\section{GENERAL GEOLOGY}

\section{Geologic Setting}

The project area, which is part of the Northern Rocky Mountains, is characterized by subparallel mountain ranges and intermontane basins that trend generally northwestward. The area of Tertiary basins lies between the Idaho batholith on the west and the Montana disturbed belt on the east and north; the basins terminate to the south against flows and associated volcanic rocks of the Snake River Plain and Yellowstone-Absaroka volcanic region (P1. 1).

Floors of the intermontane basins (valleys) are 3,500 to 7,000 $\mathrm{ft}$ above sea level and range from a $\mathrm{few}$ to as much as $20 \mathrm{mi}$ in width. Although the basins are filled mostly with Tertiary sedimentary rocks, Holocene materials are widespread at the surface and mask much of the older basin fill. The mountain ranges that separate the basins rise to elevations of 6,500 to $10,000 \mathrm{ft}$ and are principally made up of metasedimentary rocks of Precambrian age; marine sandstones, shales, and carbonate rocks of Paleozoic and Mesozoic age; continental strata of Jurassic and Cretaceous age; and andesitic volcanic 


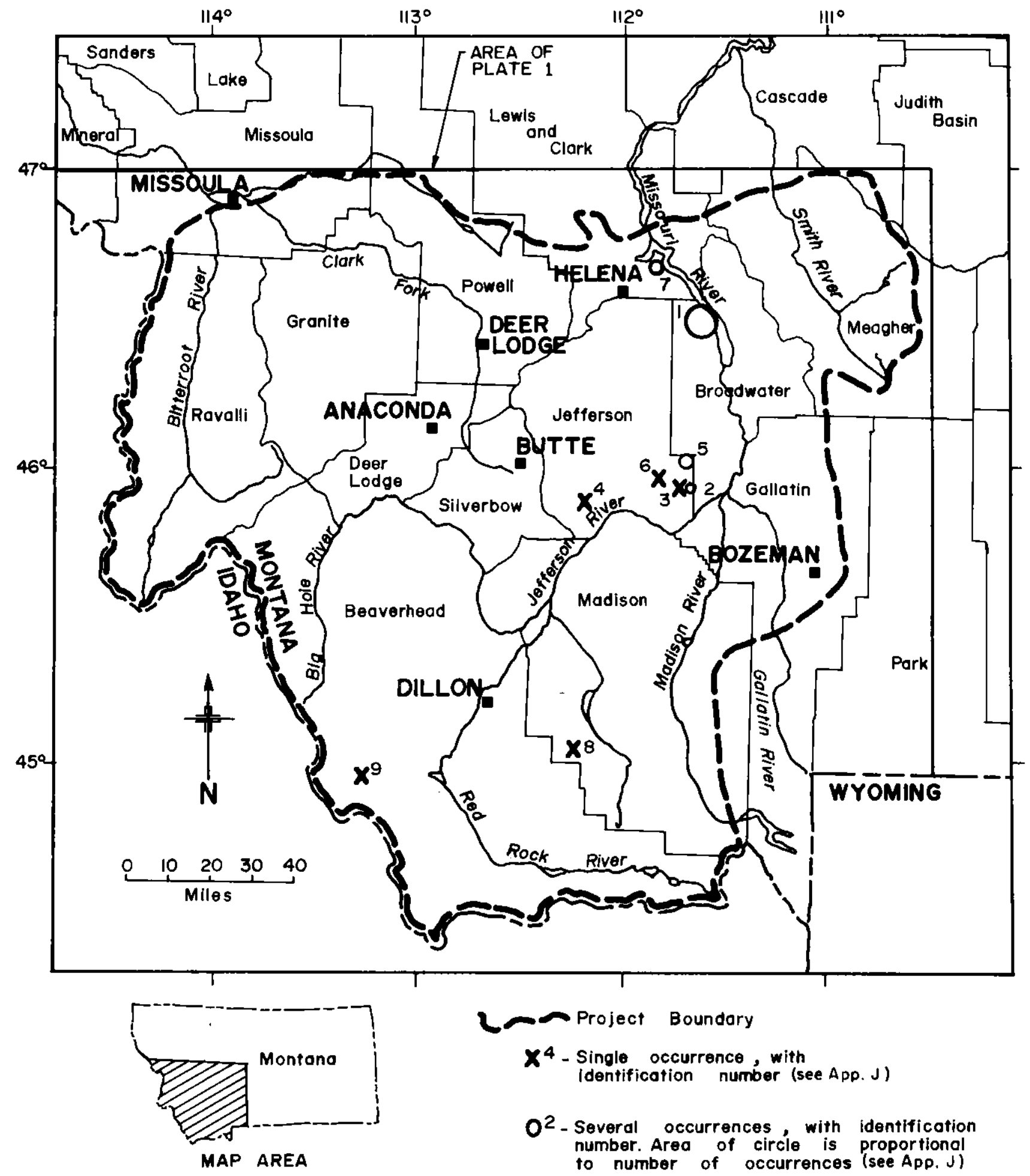

Figure 1. Southwestern Montana project area and known uranium occurrences in Tertiary basins. 
rocks of Late Cretaceous age. The Boulder batholith, which consists mostly of quartz monzonite of Cretaceous age, forms a prominent positive feature near the center of the study area and was an important provenance for sediment deposited in some of the adjacent intermontane basins during Tertiary time.

The geology is further complicated by folding, thrusting, and normal faulting. Major structural complexities are confined mostly to pre-Tertiary rocks. Tertiary strata in the intermontane basins are only mildly deformed.

\section{Tertiary Sedimentary Rocks}

The Tertiary sedimentary rocks within the project area comprise three unconformable groups: the Beaverhead Formation and two basin-fill depositional sequences called the "lower" and "upper" Tertiary sequences. The Beaverhead Formation ranges from Late Cretaceous to early Eocene in age, and was deposited as a synorogenic conglomerate in response to Laramide tectonism (Ryder and Scholten, 1973). In later orogenic phases, the Beaverhead was tilted, folded, and faulted.

Block faulting and erosion during Paleocene and Eocene time determined the configuration of the Tertiary basins and adjacent mountain ranges. During late Eocene through early Mlocene time, material that was eroded from the uplifted ranges was deposited in the basins along with silicic air-fall tuff and formed the lower Tertiary sequence. Deposition of this sequence was accompanied or, possibly, followed by eastward tilting of many of the basins. An episode of erosion in middle Miocene time removed an indeterminate thickness of previously deposited Tertiary sediments and resulted in the development of an extensive unconformity that now separates the lower Tertiary sequence from the upper Tertiary sequence. Recurrent movement along mountain-bordering faults during late Miocene to middle Pliocene time uplifted the ranges. The rejuvenated streams that drained the uplifted ranges deposited the thick upper Tertiary sequence of coarse sediments interbedded with pyroclastic material and some lacustrine beds upon the mid-Tertiary erosion surface. Varying quantities of the Tertiary sediments were removed from the basins during the present erosional episode, which was initiated in late Pliocene time.

As a result of the history described above, most of the mountain ranges and adjacent Tertiary basins are tilted to the east. The lower and upper Tertiary depositional sequences, separated by the mid-Tertiary unconformity, are lithologically distinct and can be identified in most of the Tertiary basins.

\section{Possible Sources of Uranium}

Uranium in the Tertiary sedimentary rocks was probably derived from the Boulder batholith and from silicic pyroclastic material. The Boulder batholith contains numerous uranium occurrences and is the most favorable source for uranium of any of the plutonic rocks in and near the study area. Arkosic and feldspathic sediments derived from the batholith were deposited in several 
basins adjacent to the batholith during late Eocene to P1iocene time. In some basins, uranium occurrences and radioactivity anomalies are associated with these sediments. Other nearby plutons, although less favorable, are also possible sources of uranium.

Silicic pyroclastic material is a prominent component of both the upper and lower Tertiary sequences and probably originated from eruptive centers throughout the region. These centers include those of the post-Lowland Creek volcanics, the Challis volcanics, the volcanics associated with the Yellowstone Plateau, and several local volcanic centers mapped within the project area. Some of the flows from these eruptive centers contain higherthan-average amounts of uranium. The rhyolitic post-Lowland Creek volcanics of post-early Eocene age, which crop out in and around the northern part of the Boulder batholith, contain an average of $6.1 \mathrm{ppm}$ uranium and, locally, contain as much as $18 \mathrm{ppm}$ uranium (Tilling and Gottfried, 1969, p. E11). In nearby parts of east-central Idaho, some silicic flows of the Challis volcanics of Eocene age are highly enriched in uranium. Tuffaceous beds throughout the basin-fill sequences in the project area are more radioactive than are the enclosing sedimentary beds and contain up to $17 \mathrm{ppm}$ equivalent uranium where not diluted by sediments.

\section{METHODS OF INVESTIGATION}

To facilitate field investigations, the 34 basins in the study area were arbitrarily divided into three groups: northeastern basins, south-central basins, and western basins (P1.2). Responsibility for field work, data interpretation, and report preparation was assigned to one geologist for each group of basins.

\section{Field Work}

Field work was conducted over a four-month period in 1975. Effort was concentrated on sedimentary rocks that were considered to be most favorable for potential uranium deposits on the basis of information collected from the literature and from field reconnaissance. Samples were collected from beds of potential host rocks and, wherever possible, from beds of fine-grained rocks adjacent to the potential host rocks. Stratigraphic and 1ithologic information based upon field and petrographic studies is recorded in Appendix A.

\section{Chemical Ana1yses}

All bulk rock samples were analyzed by gamma-ray spectrometry for equivalent uranium, thorium, and potassium (App. C), except for samples in which the uranium content was too high to be analyzed by this method. Thirty-nine rock samples with higher-than-average uranium values and (or) higher-thanaverage uranium-to-thorium ratios were chemically analyzed for uranium (App. D). Forty rock samples from sequences characterized by higher-than-average radioactivity and (or) favorable stratigraphic and lithologic characteristics 
were analyzed by emission spectroscopy (App. E). Six rock samples were analyzed for total and organic carbon (App. A). Fourteen water samples were analyzed for uranium by the fluorometric method (App. F).

\section{Petrographic Studies}

Fifty-eight rock samples were selected for petrographic study because of their high radioactivity or uncertain origin, classification, or composition. Petrographic studies included rock and mineral identifications, semiquantitative modal analyses, textural descriptions, and descriptions of alteration. Basic results from these studies are included in Appendix A.

\section{Subsurface Studies}

Numerous well logs were examined by the authors. The logs selected for use in this report were those which directly supplemented surface studies or which supplied information where no surface information was available.

We11 logs from 13 petroleum test wells (App. G; P1. 2) were obtained from the Montana $0 i 1$ and Gas Conservation Commission, Billings; the Rocky Mountain Well Log Service, Denver; and the American Stratigraphic Company, Denver. Lithologic logs were available for 8 wells, electric logs for 4 wells, and gamma-ray neutron logs for 3 wells.

Logs of 24 uranium exploration drill holes were obtained from Western Nuclear, Inc. (through ERDA), and from the Montana 0il and Gas Conservation Commission. Lithologic and gamma-ray logs were available for 23 drill holes, and electric logs were available for 20 drill holes. Drill cuttings from 4 holes were also used (App. I; P1. 2).

Lithologic logs for 42 water wells (App. H; P1. 2) were obtained from the Montana Bureau of Mines and Geology, Butte, and from Hackett and others (1960, Table 33). Most data available from these well logs were limited to rock type, color, and thickness. However, some logs, particularly those from Hackett and others, contained detailed lithologic descriptions.

\section{Favorability Evaluation}

Determination of the favorability for uranium was made by comparison of observed lithologic, stratigraphic, and structural characteristics of rocks in the Tertiary basins with characteristics in similar geologic settings where sandstone-type uranium deposits are known to occur. Favorability categories of good, moderate, and poor (Table 1) were subjectively selected to classify rock sequences that occupy the basins. Most of the criteria used to judge the favorability of the rock sequences are those given by Grutt (1972, Tables 2, 3). 
TABLE 1. RELATIVE FAVORABILITY RATING SYSTEM

\begin{tabular}{|c|c|c|c|c|}
\hline $\begin{array}{l}\text { Favorability } \\
\text { rating }\end{array}$ & $\begin{array}{l}\text { Favorable sedimentary } \\
\text { rock sequence } \frac{\text { a }}{}\end{array}$ & $\begin{array}{l}\text { Uranium occurrences } \\
\text { and (or) radioactivity } \\
\text { anomalies }\end{array}$ & $\begin{array}{c}\text { Samples with } \\
\text { anomalous } \\
\text { chemical composition } \text { / }\end{array}$ & $\begin{array}{l}\text { Evidence of } \\
\text { reducing } \\
\text { condition }\end{array}$ \\
\hline good & yes & numerous & numerous & yes \\
\hline moderate & yes & few & few & yes \\
\hline \multirow[t]{2}{*}{ poor } & $-\{$ yes & none & none & no \\
\hline & no & none & some or none & yes or no \\
\hline
\end{tabular}

a/ More than 1,000 ft thick, contains 30-80 percent sandstone and (or) conglomerate, contains one or more beds of medium- to coarse-grained sandstone or conglomerate between 20 and $200 \mathrm{ft}$ thick, and generally contains tuffaceous material.

b/ Surface and (or) subsurface.

c/ (1) Anomalously high equivalent uranium content relative to equivalent thorium or (2) above average equivalent uranium content relative to equivalent thorium accompanied by one or more other possible chemical indicators.

d/ Potential host rock and (or) adjacent fine-grained rocks contain direct (carbonaceous material, pyrite) or indirect (petrified wood) evidence of reducing conditions. 
Favorability is indicated by the following:

1. Thick (1,000 ft or more) sequence of Tertiary sedimentary rocks derived from granitic and silicic volcanic provenances;

2. 30-80 percent sandstone and (or) conglomerate, some beds of which are 20 to $200 \mathrm{ft}$ thick, light colored (where indicative of a reducing environment), feldspathic to arkosic, poorly sorted, medium to coarse grained, and (or) permeable;

3. Carbonaceous material or pyrite in or adjacent to potential host rocks and presence of a reducing fluid or gas in wells that penetrate such rocks;

4. Uranium occurrences, radioactivity anomalies, and favorable geochemical indicators ${ }^{a /}$ in Tertiary strata;

5. Pervasive postdepositional alteration (for example, iron staining) of potential host rocks;

6. Unconformities that bound or are within the rock sequence;

7. Siliceous, tuffaceous rocks superjacent to potential host rocks; and

8. Gentle dips $\left(1^{\circ}\right.$ to $\left.5^{\circ}\right)$ and presence of faults.

\section{ACKNOWLEDGEMENTS}

The authors are indebted to Western Nuclear, Incorporated, and to the Montana Power Company for providing subsurface logs and other information; to the Montana Bureau of Mines and Geology and the 0il and Gas Commission of the State of Montana for permission to make copies of pertinent subsurface logs and other information; to Dr. Robert Lankston, Gulf Research Laboratories, Houston, for providing geophysical data for the Bitterroot Basin; and to U.S. Geological Survey personnel of the Public Information office in Spokane for general assistance in literature research. Field assistance during the study was provided by Michael Berry, Deborah Highley, Peter Kurisoo, and Kevin Sylvester.

\footnotetext{
a/ Favorable geochemical indicators are high concentrations of the elements $\mathrm{U}$ (or eU), As, B, Cr, Cu, Ga, Li, $\mathrm{Mn}, \mathrm{Mo}, \mathrm{Nb}, \mathrm{P}, \mathrm{Se}, \mathrm{Sn}, \mathrm{V}$, and $\mathrm{Zn}$ (Marjaniemi and Robins, 1975a, 1975b; Grutt, 1972, p. 53) and high ratios of eU/eTh in potential host rocks, in argillaceous interbeds, and in waters that may have passed through these rocks. The significance of a high equivalent uranium content of an individual rock sample was determined by comparing the uranium content to both (1) the equivalent thorium content of the sample (using the ratio eU/eTh or a plot of eU versus eTh for a control group of samples) and (2) the mean equivalent uranium content of a control group of samples. The significance of a high uranium content in a specific water sample was determined by comparison of its uranium content with the mean uranium content of all water samples analyzed for the project.
} 
NORTHEASTERN BASINS

by

M. A. Wopat

The seven northeastern basins (Fig. 2) contain some of the best exposures and some of the most favorable rocks in the project area. These basins are discussed in an approximate south-to-north order. The large Three Forks basin has been divided into an eastern and a western part because the favorability characteristics significantly differ between the two parts.

WESTERN THREE FORKS BASIN

Eocene and Oligocene Rocks

Data were obtained from surface studies of 18 localities (301-306, $308-315,324-326,364, \mathrm{P} 1.2$ ); analyses of 53 rock samples and 1 water sample from these localities (App. A); logs of 4 water wells, 6 petroleum test wells, and 7 uranium exploration drill holes (P1. 2; Fig. I-1); 3 measured sections described in the literature (App. B); and cited references.

Eocene and 0ligocene rocks have been mapped as four lithologically distinct formations in the Three Forks quadrangle (Robinson, 1963) and in the northern part of the contiguous Norris quadrangle (Feichtinger, 1970). These formations, from oldest to youngest, are: (1) the Sphinx Conglomerate of Eocene age, (2) the Milligan Creek Formation of Eocene age, (3) the Climbing Arrow Formation of the late Eocene and early 0ligocene age, and (4) the Dunbar Creek Formation of Oligocene age.

The Sphinx Conglomerate is principally a limestone conglomerate with a porous earthy matrix. It crops out only near the basin edges, but it may occur in subsurface as a widespread basal unit in pre-Tertiary valleys in the western part of the basin. A few coal layers were penetrated in the upper part of the Sphinx by a petroleum test well (no. 1) in the Madison valley (Hackett and others, 1960, p. 35).

The Milligan Creek Formation is thin (0-300 ft), of limited areal extent, and composed of fine-grained tuffaceous lacustrine deposits, with minor zones of intertonguing fluvial conglomerate and sandstone. The formation crops out only in the Jefferson River valley.

The Climbing Arrow Formation is as much as $1,500 \mathrm{ft}$ thick, 35 percent of which is composed of fluvial sandstone and conglomerate. This formation is the most extensively exposed of the four that form the Eocene-01igocene sequence; for this reason, most of the data from which favorability of the western Three Forks basin is determined were derived from the Climbing Arrow Formation.

The Dunbar Creek Formation comprises 15 percent fluvial sandstone and conglomerate, 80 percent thick-bedded tuffaceous siltstone and sandstone, and 5 percent limestone and claystone. Much of the fine constituent is airborne volcanic ash (Robinson, 1963, p. 121), which could be a source of uranium. 


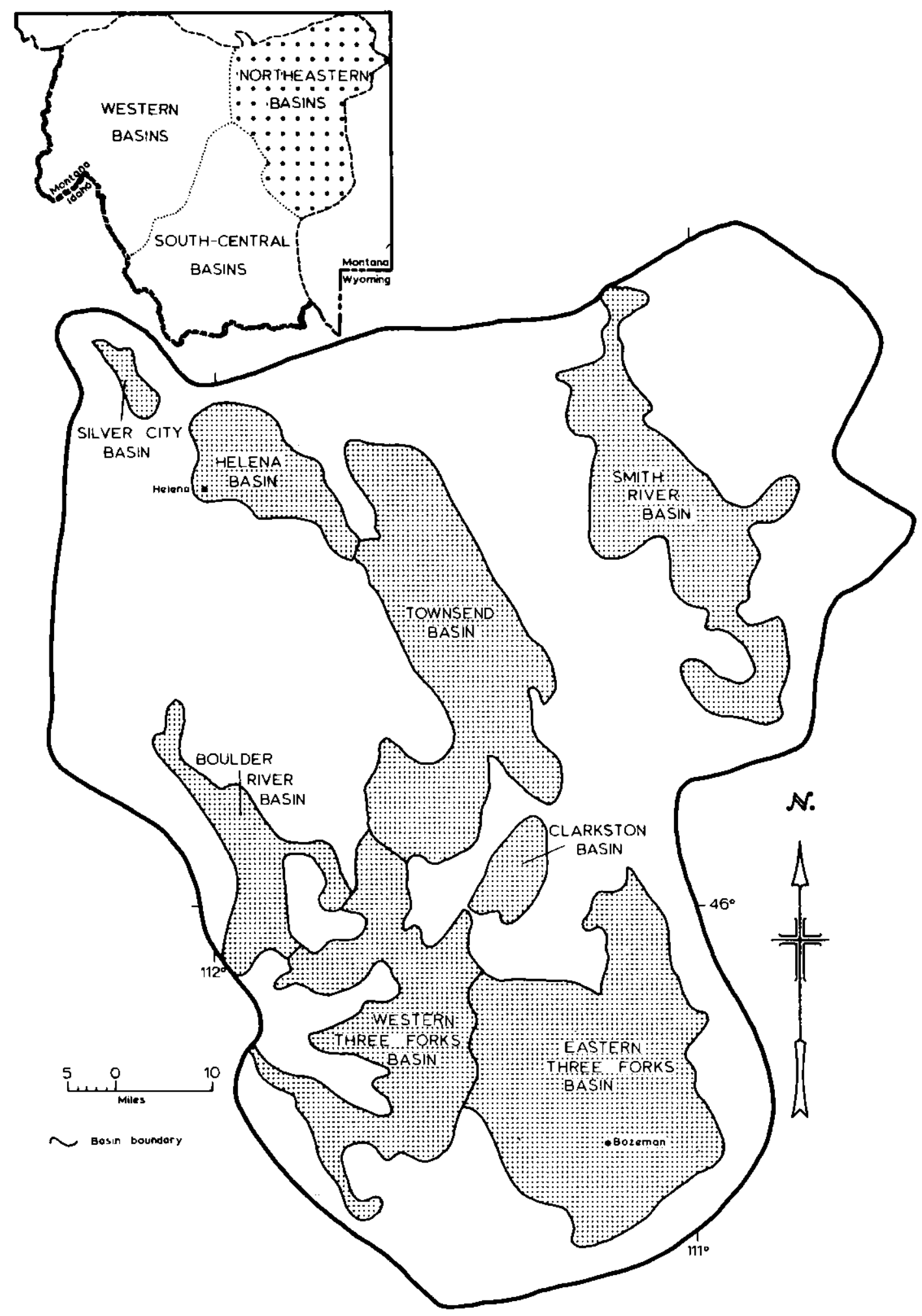

Figure 2. Locations and names of Tertiary basins in the northeastern part of the study area. 
Favorability Characteristics. Robinson (1963, p. 60) reported that the Tertiary sedimentary rocks in the Three Forks quadrangle are generally less than $1,000 \mathrm{ft}$ thick, but locally may be as much as 2,500 ft thick. In the contiguous Jefferson Island quadrangle to the west, these rocks probably have a maximum thickness of about $400 \mathrm{ft}$ (Richard, 1966, P1. 5). The thickness of the lower Tertiary rocks in six locations is shown by the wells and drill holes that bottom in the pre-Tertiary rocks (Table 2). Geophysical evidence (Davis and others, 1965b) indicates that the Tertiary basin deposits near the town of Three Forks may be as much as 3,000 ft thick on the west side of the Madison River valley, but are probably less than 1,000 ft thick within the Jefferson River valley. The rocks are bounded by an erosion surface of Late Cretaceous to early Eocene age below and an unconformity of middle 0ligocene to middle Miocene age above (Robinson, 1963, p. 61).

Sandstone and conglomerate average 25 percent of measured sections and 38 percent of subsurface intervals (Table 2). Between 35 and 45 percent may be a more representative estimate because most of the measured sections and wells for which sandstone percentages were calculated are in the fine-grained sedimentary facies away from the basin edges. Also, a thick basal conglomerate, which is believed to underlie most of the basin, was penetrated by only two deep petroleum test wells (nos. 1, 5) and was not measured during surface investigations; it is therefore poorly represented in the calculated sandstone percentages. Robinson's (1963, p. 60) value of 45 percent for the proportion of sandstone and conglomerate in early Tertiary rocks of the Three Forks quadrangle further indicates that the percentages measured are minimum ones.

Potential host rocks range from medium-grained sandstone to conglomerate. The sandstone is poorly sorted and is arkosic or feldspathic in most localities. Some of the beds penetrated by petroleum test well 5 are feldspathic. The potential host rocks generally are permeable, and iron staining is common. These rocks form beds which average less than $10 \mathrm{ft}$ in thickness, although beds as much as $25 \mathrm{ft}$ thick in outcrop (Apps. A, B) and as much as $120 \mathrm{ft}$ thick in the subsurface (Table 2) are known. The basal conglomerate, which is as much as $100 \mathrm{ft}$ thick in outcrop (Robinson, 1963, p. 1), is 300 to $400 \mathrm{ft}$ thick in the subsurface and contains beds that range from 5 to $105 \mathrm{ft}$ thick and average $51 \mathrm{ft}$ thick (petroleum test we11 5).

Except for localized concentrations of petrified wood and lesser amounts of petrified bone, organic material is present only in trace amounts in outcrop. A few layers and seams of coal and a trace of carbonaceous shale were intercepted in the subsurface (Table 2).

Tuffaceous material is common throughout the section (Robinson, 1963, p. 60). Most beds contain some Tertiary volcanic ash, and many strata are composed wholly of such material (for example, 1oc. 304, units 11 and 12, App. A). The Dunbar Creek Formation in the western part of the basin is formed mostly of airborne ash (Robinson, 1963, p. 121). 
TABLE 2. SUMIARY OF DATA FROM SUBSURFACE INTERVALS OF EOCENE AND OLIGOCENE ROCKS IN THE WESTERN THREE FORKS BASIN

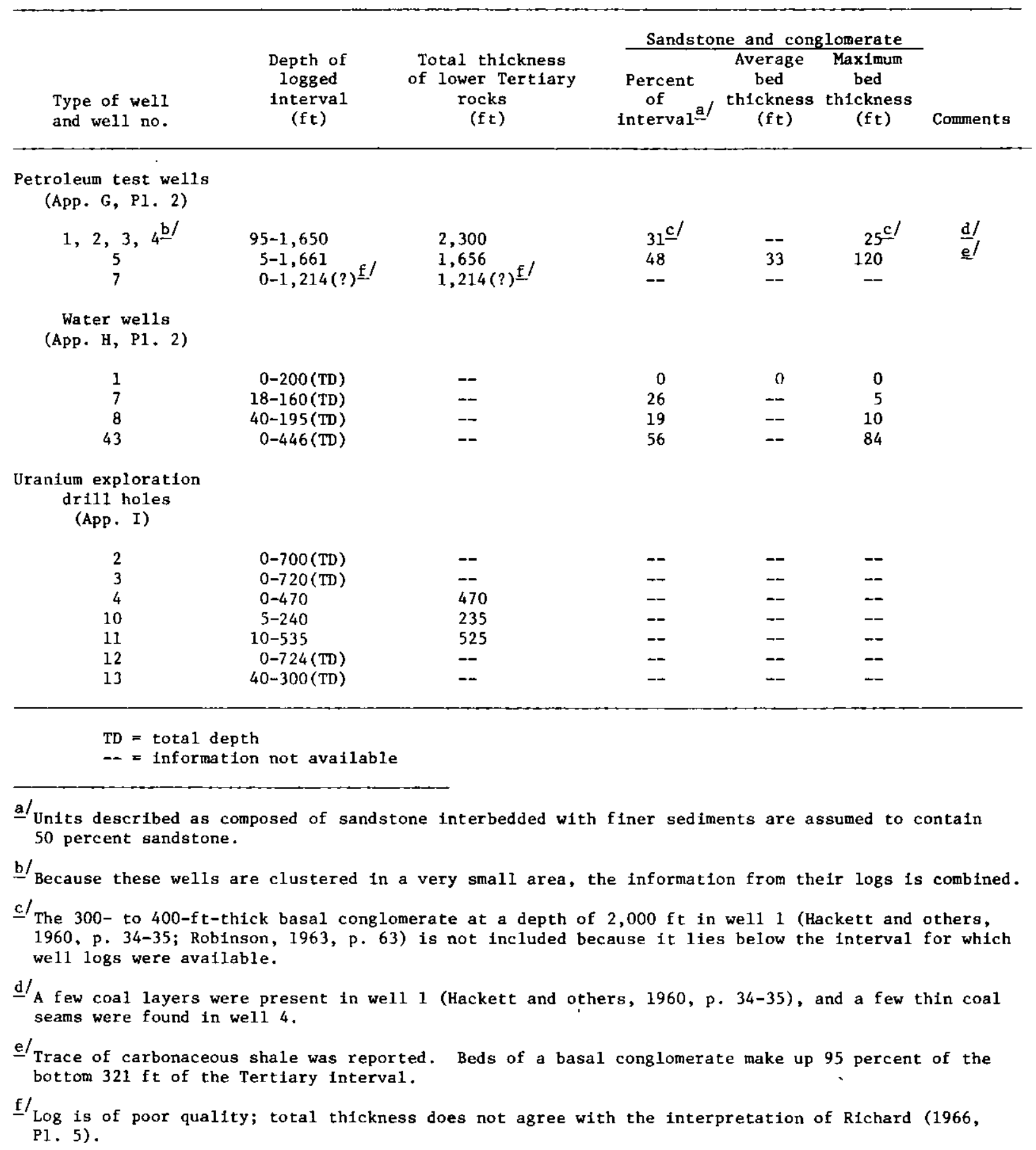


Several uranium occurrences (nos. 2, 3, 5, 6, Fig. 1, App. J) have been reported northwest of the town of Three Forks, and meta-autunite and coffinite were found nearby at locality 325. "Slight mineral" was reported on the log of uranium exploration drill hole 11, and numerous subsurface radioactivity anomalies (Table I-2) were recorded on gamma-ray logs from the uranium exploration drill holes that are also near the reported uranium occurrences. Petroleum test well 3, southeast of the town of Three Forks, penetrated a 6-ft-thick anomalously radioactive (2 to 3 times background) bed at a depth of $742 \mathrm{ft}$.

Rock sample 325-5 contains 0.94 percent uranium (App. D). Equivalent uranium values of the rest of the samples of these rocks are generally much higher than those of the western and south-central basins (Fig. 3). Furthermore, the mean equivalent uranium value and the mean eU/eTh ratio of these samples are higher than those from most other basins in this study (exceptions are the Townsend, Clarkston, and Helena basins) (Table 3). Sixteen rock samples $(301-2,301-6,302-1,302-6,305-2,312-1,312-2$, 314-2, $324-1,324-2,324-3,325-2,325-3,325-4,326-1,326-2$ ) from eight study localities are anomalously high in equivalent uranium (App. C). Three samples (301-6, 324-1, 326-1) also contain anomalously high concentrations of other favorable geochemical indicators (App. E). Of the sixteen rock samples for which both equivalent and chemical uranium analyses were available, four (302-6, 303-1, 324-1, 324-3) are in disequilibrium (Fig. K-1). One water sample $(308-I)$ is anomalously high in $\mathrm{U}_{3} \mathrm{O}_{8}(40 \mathrm{ppb}$, App. F).

These chemical characteristics do not indicate uniform favorability throughout the area underlain by these rocks, but rather reflect the favorability of each of the four lower Tertiary formations. The sample containing 0.94 percent $\mathrm{U}_{3} \mathrm{O}_{8}$ is from the Climbing Arrow Formation. The 39 other rock samples from this formation contain an average of $59 \mathrm{ppm}$ equivalent uranium, and the 1 water sample, taken from a spring that rises from the Climbing Arrow, contains $40 \mathrm{ppb} \mathrm{U}_{3} \mathrm{O}_{8}$. In contrast, the 2 rock samples collected from the most favorable outcrop of the Milligan Creek Formation contain an average of $32 \mathrm{ppm}$ equivalent uranium, and the 9 rock samples from the Dunbar Creek Formation have an average equivalent uranium content of 6 ppm. The Sphinx Conglomerate was not sampled.

Dips commonly are $5^{\circ}$ to $10^{\circ}$ and rarely are as much as $25^{\circ}$ (Robinson, 1963 , p. 61). Post-Tertiary faults have been mapped only near the southern margin of the western Three Forks basin, near the Madison River (Feichtinger, 1970 , p. 37, P1s. I, III). Evidence of late- or post-Tertiary movement on the eastern extension of the Willow Creek fault zone (Robinson, 1963,

a/ The equivalent uranium (eU) content of a rock sample from the northeastern basins is considered to be anomalously high if the eU/eTh ratio of the sample is 1.0 or more and the eU value is $8.7 \mathrm{ppm}$ or more. The $8.7 \mathrm{ppm}$ value is the mean (3.3 ppm eU) plus two standard deviations ( 1 std dev $=2.7 \mathrm{ppm}$ eU) of the eU values of the rock samples from the south-central and western basins. A meaningful cutoff value cannot be derived from the eU values of the rock samples from the northeastern basins because the distribution of these values is greatly skewed (Fig. 3). 


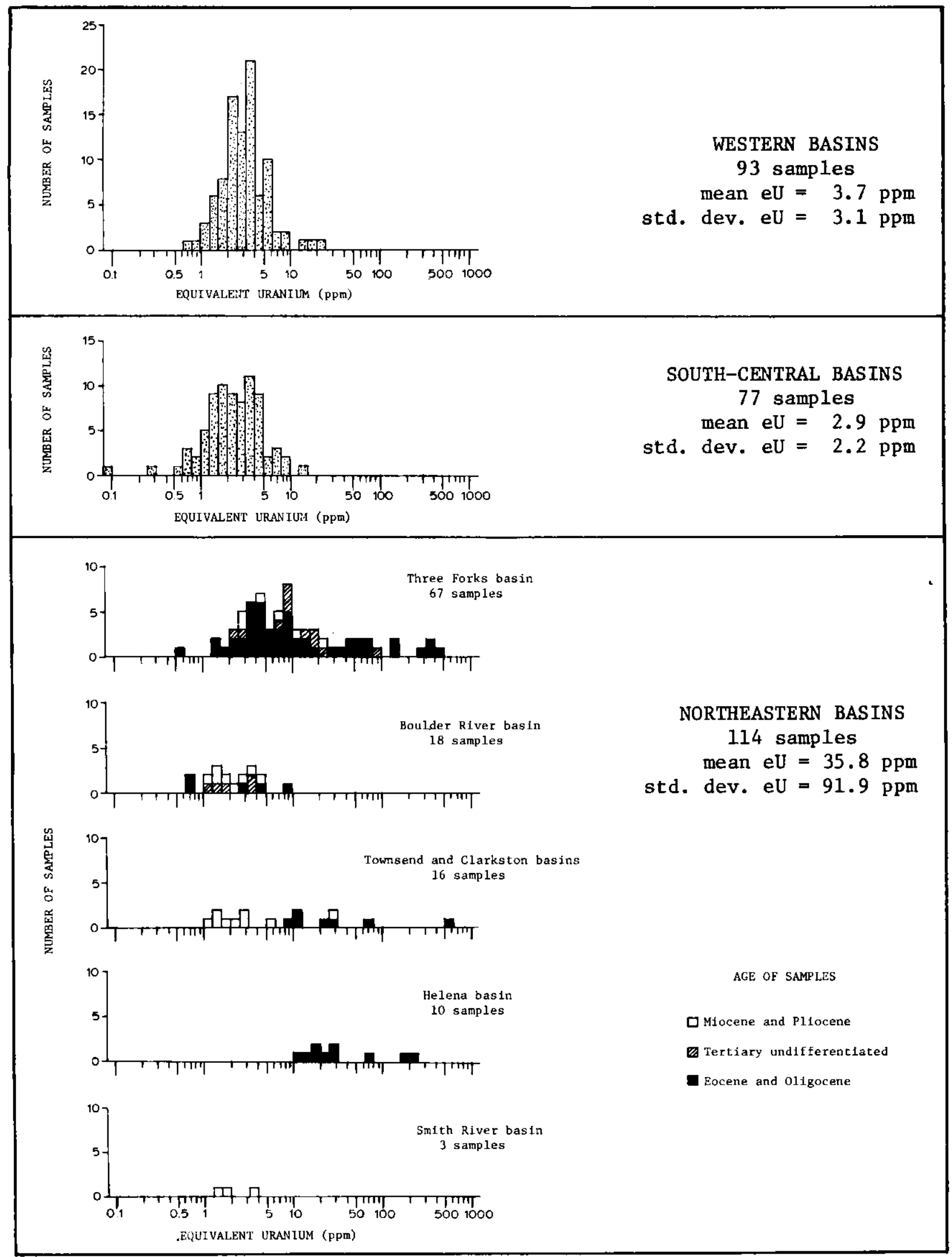

Figure 3. Distribution of equivalent uranium content of samples from individual northeastern basins compared with distributions for the southcentral basins and the western basins. (Includes all samples used in Table 3) 
TABLE 3. MEAN EQUIVALENT URANIUM AND THORIUM CONTENT OF ALL ROCK SAYPLES ${ }^{3}$, BY BASIN AND AGE

\begin{tabular}{|c|c|c|c|c|c|c|c|c|}
\hline & & Number of & el & $(\mathrm{ppm})$ & & $(\mathrm{ppm})$ & el & eeth \\
\hline & Sample Group & samples & mean & std dev & mean & std dev & mean & std dev \\
\hline & Undifferentiated Tertiary & 11 & 18.1 & 23.4 & 11.6 & 6.7 & 1.35 & 0.90 \\
\hline & Three Forks basin, western part Eocene and Oligocene & 50 & 48.0 & 103.4 & 16.3 & 11.9 & 3.00 & 6.00 \\
\hline & All samples & 61 & 42.6 & 94.7 & 15.5 & 11.2 & 2.71 & 5.47 \\
\hline q & Three Forks basin, eastern part - Miocene and Pliocene & 6 & 8.4 & 7.6 & 7.5 & 1.6 & 1.20 & 1.14 \\
\hline 点 & SMiocene and Pliocene & 8 & 2.3 & 1.1 & 10.4 & 3.6 & 0.22 & 0.06 \\
\hline$m$ & Undifferentiated Tertiary & 5 & 2.3 & 1.2 & 12.5 & 3.5 & 0.17 & 0.05 \\
\hline z & Boulder River basin Eocene and Oliogcene & 5 & 3.5 & 3,4 & 18.5 & 9.2 & 0.17 & 0.10 \\
\hline 㩄 & A11 samples & 18 & 2.6 & 2.0 & 13.3 & 6.4 & 0.19 & 0.07 \\
\hline 絰 & SMiocene and Pliocene & 9 & 5.0 & 7.7 & 11.6 & 6.2 & 0.98 & 2.32 \\
\hline 穿 & Townsend and Clarkston basins \{0ligocene & 7 & 107.7 & 220.0 & 34.9 & 15.2 & 3.05 & 5.20 \\
\hline & LAll samples & 16 & 49.9 & 148.9 & 21.8 & 16.0 & 1.89 & 3.85 \\
\hline & Helena basin - oligocene & 10 & 57.7 & 70.6 & 28.8 & 12.8 & 2.69 & 4.03 \\
\hline & Smith River basin - Miocene and Pliocene & 3 & 2.2 & 1.1 & 17.7 & 15.6 & 0.16 & 0.07 \\
\hline & Jefferson River, Beaverhead River, & & & & & & & \\
\hline $\begin{array}{l}3 \\
3 \\
0\end{array}$ & Lower Ruby River, and Divide Creek basins & 32 & 3.4 & 2.4 & 12.9 & 7.9 & 0.28 & 0.16 \\
\hline 我 & Upper Ruby River and Sage Creek basins & 24 & 2.8 & 1.5 & 12.7 & 8.2 & 0.23 & 0.07 \\
\hline$\underset{z}{\underline{\alpha}}$ & Red Rock and Centennial basins & 3 & 0.6 & 0.3 & 2.7 & 1.9 & 0.37 & 0.35 \\
\hline 岕 & $\begin{array}{l}\text { Grasshopper Creek, Horse Pra1rie, Muddy Creek, } \\
\text { Medicine Lodge Creek, and Big Sheep Creek basins }\end{array}$ & 12 & 3.1 & 2.9 & 7.9 & 8.3 & 0.59 & 0.58 \\
\hline n & Madison River basin & 6 & 1.9 & 1.2 & 7.6 & 4.9 & 0.26 & 0.08 \\
\hline$\infty$ & Deer Lodge, F1int Creek, and Gold Creek basins & 34 & 3.2 & 1.5 & 9.6 & 4.4 & 0.37 & 0.18 \\
\hline 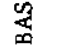 & Big Hole, Bull Creek, and Deep Creek basins & 30 & 4.4 & 4.7 & 9.6 & 4.1 & 0.47 & 0.41 \\
\hline 毞 & Wise River, Blackfoot, Douglas Creek, Avon, and & & & & & & & \\
\hline 罢 & Rock Creek basins & 13 & 3.0 & 1.5 & 9.5 & 4.8 & 0.35 & 0.17 \\
\hline 3 & Bitterroot River basin & 16 & 4.0 & 3.0 & 13.4 & 8.9 & 0.32 & 0.16 \\
\hline
\end{tabular}

a Includes all samples analyzed by gamma-ray spectrometry except those of probable pyroclastic origin and those which are hydrothernally altered $(140-1,140-2,222-1,224-1,230-1,231-1,238-1,239-1,245-1,250-1,254-1,304-3,304-4,333-1,335-2,336-1,30$ and $336-2)$. 
page 13, P1. 3) was observed just east of the Madison River (Schneider, 1970, p. 36; Hackett and others, 1960, p. 51-55). Although this movement most likely affected the Tertiary sedimentary rocks west of the Madison River, Robinson (1963, p. 61) did not map any faults that cut the Tertiary rocks in the Three Forks quadrangle.

The western part of the Three Forks basin is approximately $25 \mathrm{mi}$ from the Boulder batholith. Eastward drainage from the batholith in early Tertiary time transported batholithic detritus through, and perhaps across, the ancient Boulder River and northern Jefferson River valleys into the Three Forks basin. Most of the lower Tertiary sediments in the basin were deposited by eastward- and, perhaps, northeastward-flowing streams. The Climbing Arrow Formation, for example, comprises sediment derived from the ancestral Elkhorn, Madison, and Tobacco Root Mountains and from the Boulder batholith (Robinson, 1963, p. 95, 121).

Conclusions. Favorability for uranium in Eocene and 0ligocene rocks of the western Three Forks basin is judged to be good because of the presence of a favorable sedimentary rock sequence (Table 1), several uranium occurrences, numerous radioactivity anomalies, and high concentrations of uranium in 17 of the 53 rock samples and in 1 water sample. Abundant tuffaceous material, ample evidence of reductants, and proximity of the area to the Boulder batholith further enhance the favorability. In addition, the Eocene-0ligocene sequence is bounded by unconformities. The favorability rating is adequately supported by the large volume of data from the surface and subsurface geologic studies.

Although no specific attempt was made during the study to separately evaluate the four formations that make up the Eocene and Oligocene rocks, results indicate that the rocks are not uniformly favorable. The climbing Arrow Formation is the most favorable of the four formations; 15 of 17 rock samples that contain anomalously high uranium concentrations are from climbing Arrow beds. The Dunbar Creek Formation, although not as favorable as the subjacent Climbing Arrow Formation, contains units with anomalous uranium concentrations (sample 314-2) and warrants further evaluation. Because of its volcanic ash content, the Dunbar Creek could be a source of uranium for underlying rocks. The Sphinx Conglomerate is lithologically unfavorable as a uranium host rock, and no radioactivity anomalies were found to warrant sampling or further examination of the formation. The Milligan Creek Formation contains possible host rocks (1oc. 305), but the limited thickness, the limited areal extent, and the dominance of unfavorable lithology indicate generally poor favorability for potential uranium deposits.

\section{Undifferentiated Tertiary Rocks}

Data were obtained from surface studies of 7 localities $(318,319$, $340-342,377,378, P 1.2)$, analyses of 12 rock samples and 1 water sample from these localities (App. A), and cited references.

Favorability Characteristics. Maximum thickness of the undifferentiated Tertiary sequence is about 1,500 ft near the Willow Creek Reservoir, east of Harrison (Davis and others, 1965b); the sequence is at least $711 \mathrm{ft}$ thick in 
Antelope Creek valley, northwest of Harrison (Richard, 1966, p. 40). The sandstone percentage of the sequence is unknown, but small outcrops examined near Harrison and Norris contain a larger proportion of coarse sediments than the overlying limestone and tuffaceous siltstone unit mapped east of Harrison by Feichtinger (1970). Andretta and Alsup (1960, p. 185) indicate that the Tertiary sedimentary rocks in the valley between Harrison and Norris are mainly siltstone and sandstone.

Potential host rocks range from conglomerate to medium-grained sandstone and are feldspathic to arkosic. The sandstone is moderately to poorly sorted and is medium to very coarse grained. The potential host rocks form beds that average $12 \mathrm{ft}$ thick and.that attain a maximum thickness. of $25 \mathrm{ft}$. These rocks range from soft, where not cemented, to very hard, where cemented by silica; permeability varies inversely with hardness. The rocks are iron stained at three localities but are very light colored (reduced?) at localities 341 and 378. The pervasive hematitic staining of rocks at locality 318 may be due to hot-springs activity (Andretta and Alsup, 1960, p. 186). Traces of petrified wood were found in both the fine and coarse sedimentary rocks northwest of Harrison. Traces of petrified wood containing carnotite were found at localities 341 and 378 .

The siltstone beds at localities 318 and 342 are tuffaceous. The finer sedimentary rocks that are inferred to overlie the rocks of the study localities include the tuffaceous siltstone described by Feichtinger (1970, p. 21, 79-81). Glass shards are common in the Tertiary sedimentary rocks that underlie the valley between Harrison and Norris (Andretta and Alsup, 1960, p. 185).

Rock sample 341-1, which is petrified wood, contains the highest concentration of uranium (2.58 percent) of all samples collected for this study. Even discounting this sample, the equivalent uranium values of the remaining samples are generally higher than values recorded from the western and south-central basins (Fig. 3). Furthermore, the mean equivalent uranium value and the mean eU/eTh ratio are higher in the undifferentiated Tertiary sequence of the western Three Forks basin than in the western and south-central basins (Table 3). A total of five rock samples (318-1, 340-1, $341-4,341-5,342-4)$ from four localities are anomalously high in equivalent uranium content. The three samples (318-1, 342-2, 343-3) analyzed for other favorable geochemical indicators all contained anomalously high concentrations of one or more of the indicators (App. E). The high concentrations support the anomalously high uranium content of sample $318-1$, and are in agreement with other characteristics that suggest a high favorability rating for locality 342 .

The undifferentiated Tertiary rocks unconformably overlie all older rocks, which have experienced various degrees of deformation; however, no dips steeper than $10^{\circ}$ were found in the Tertiary rocks. Evidence of postTertiary faulting has been observed only east of the town of Norris, where shear and drag folds in the Tertiary sedimentary rocks indicate movement along the Warm Springs Fault Zone (Andretta and Alsup, 1960, p. 188). Although evidence of post-Tertiary movement on the northwest-trending Cherry Creek and Elk Creek faults has been observed only near the Madison River 
(Feichtinger, 1970, p. 37, P1s. I, III), this movement may have affected Tertiary sedimentary rocks that overlie the faults (Davis and others, 1965b) northwest of Harrison.

Eastward drainage from the Boulder batholith transported batholithic detritus to the western Three Forks basin in Tertiary time. The Tobacco Root batholith contributed detritus to Tertiary sedimentary rocks that underlie the valley between Norris and Harrison and was also the source of feldspathic sediments east of Norris (Andretta and Alsup, 1960, p. 185,186$)$.

Conclusions. Favorability for uranium deposits in the undifferentiated Tertiary rock sequence in the western Three Forks basin is rated good to moderate. The rating is based on the presence of feldspathic to arkosic potential host rocks, abundant tuffaceous material, anomalously high uranium content in six rock samples, and petrified wood with carnotite. Furthermore, an unconformity separates the sequence from subjacent older rocks; and the area is proximal to the uraniferous Boulder batholith, from which some of the sediment in the sequence was probably derived.

The available information is limited because outcrops are sparse and subsurface information is lacking. Most of the data were derived from surface studies of the best exposed outcrops, which are clustered in two smal1 areas (P1. 2). Therefore, the favorability rating is considered valid only for rocks in and near the areas of outcrop.

\section{EASTERN THREE FORKS BASIN}

Data were obtained from surface studies of four localities (P1. 2); analyses of six rock samples from the study localities (App. A); logs of nine water wells, one petroleum test well, and one uranium exploration drill hole (P1. 2); examination of the rocks in six measured sections described in the literature (App. B); published descriptions of two other sections not examined during this study; and cited references.

Tertiary rocks that underlie the eastern Three Forks basin are predom: inately of Miocene and Pliocene age (P1. 1). Also, rocks of 0ligocene age (Klemme, 1949, p. 68; Verrall, 1955, p. 172-173; loc. 362) and of undifferentiated Tertiary age (Hackett and others, 1960, p. 39) underlie part of the basin. These three age groups are distinguished on the map of the basin (P1. 1). However, they are not treated separately in the favorability discussion because (1) little information is available for rocks of oligocene and undifferentiated Tertiary age and (2) age subdivisions of the Tertiary section are not readily distinguishable on the well logs.

\section{Favorability Characteristics}

The maximum thickness of Tertiary rocks is $6,000 \mathrm{ft}$ in the southernmost of three bedrock depressions that underlie the Cenozoic sediments east of longitude $111^{\circ} 15^{\prime} \mathrm{W}$. (Davis and others, 1965a; Burfeind, 1967). In the central depression the rocks are about 5,000 ft thick, and in the northernmost 
depression the rocks are 3,000 ft thick or less. These thick sequences are separated from the 2,300-ft-thick Tertiary sequence near the Madison River by a north-trending bedrock high over which the Tertiary rocks thin to less than 1,000 ft. Tertiary strata unconformably overlie all older rocks throughout the basin.

Sandstone and conglomerate make up about 30 percent of the Tertiary section. The coarser sedimentary rocks average 40 percent in measured section and make up 22 percent of the Tertiary sedimentary rocks penetrated by the nine water wells.

The sandstone and conglomerate form beds that average 20 to $25 \mathrm{ft}$ thick; beds as thick as $40 \mathrm{ft}$ are common. Feldspar content is generally low; feldspathic sands were found only in measured sections 51 and 55 (App. B). Sandstones are medium to very coarse grained, very poorly to well sorted, and permeable where not cemented or claybound. All measured sections, wells, and study localities (except measured section 53 and locs. 317 and 361) contain some calcite-cemented rocks. In many places calcite appears to have been deposited penecontemporaneously as a caliche horizon (Mifflin, 1963, p. 22; Glancy, 1964, p. 21, 22); thus, some of the possible host rocks may have been relatively impermeable since the time of deposition. Iron staining generally is uncommon and was found only in locality 316 and in measured sections 48 and 51 (App. B).

Traces of carbonaceous dendrites, bone fragments, and petrified wood were found in outcrop (App. B). Beds containing petrified wood and (or) bone were penetrated by water wells 48 and 49 . Water wells 4,45 , and 48 penetrated beds of pyritic sand and clay. The pyritic rocks in these wells range in thickness from $39 \mathrm{ft}$ (well 48) to $191 \mathrm{ft}$ (well 45) and are found near the base of the Tertiary sequence just above Precambrian basement rocks in which all three wells bottom. Individual sand beds in the pyritic section are 20 to $26 \mathrm{ft}$ thick.

Pyroclastic material probably makes up more than half of the rock. Ash beds; 15 to $35 \mathrm{ft}$ thick, are found both near the Madison River valley (Schneider, 1970, p. 23) and near Bozeman (Glancy, 1964, p. 24; 1oc. 361, this report).

Although five of the six rock samples are from one locality (316) near the western part of the basin, the mean equivalent uranium content and mean eU/eTh ratio of the six samples are higher than those from most other basins in this study (exceptions are the Helena, Townsend, Clarkston, and western Three Forks basins) (Table 3). Rock samples 316-2 and 316-4 are anomalously high in equivalent uranium content.

Tertiary strata generally dip $1^{\circ}$ to $5^{\circ}$ to the east. However, local variations are numerous, and dips up to $35^{\circ}$ have been recorded. Evidence of post-Tertiary movement has been observed both along the trace of the Willow Creek fault (Schneider, 1970, p. 36; Hackett and others, 1960, p. 51-55), which extends eastward from the Jefferson River canyon (Robinson, 1963, p. 13, PI. 3) to the Bridger Range (Davis and others, 1965a), and along the trace of a small north-trending fault mapped in the bluffs just east of the Madison River and north of the Willow Creek fault (Schneider, 1970 , p. 38, P1s. I, II). Other evidence of possible faulting is presented by Robinson (1961, p. 1009-1010) and Hackett and others (1960, p. 50). 
Detrital sediments in the bluffs just east of the Madison River were deposited by northeastward-flowing streams and were derived from mountains to the west and southwest of the basin (Schneider, 1970, p. 14). Near the eastern edge of the basin, coarse sediments were derived from sources to the south and east (McMannis, 1955, p. 1413; Glancy, 1964, p. 30).

Eocene and 0ligocene rocks, which are rated as having good favorability for uranium deposits in the contiguous western part of the basin, dip under the younger Tertiary rocks in the eastern part of the basin. Although the easternmost subsurface extent of the favorable older Tertiary rocks is not known, these rocks may be present in deep bedrock depressions and may underlie much of the younger strata in the eastern part of the basin. The probable existence of older Tertiary rocks in the subsurface enhances the favorability of the eastern Three Forks basin.

\section{Conclusions}

Favorability for uranium deposits in Tertiary rocks of the eastern Three Forks basin is rated moderate. Favorability is not uniform across the eastern part of the basin, but increases from poor, east of the Gallatin River, to moderate, west of the river. West of the Gallatin River, the sandstone content increases westward, evidence of reductant is found both in outcrop and in the subsurface, the favorable lower Tertiary rocks dip under the less favorable upper Tertiary rocks, and anomalously high concentrations of uranium are found in two rock samples. East of the Gallatin River, the Tertiary sequence is very thick in bedrock depressions, the favorable lower Tertiary rocks may be present at depth, and evidence of reductant material was found in one well.

The conclusions are based upon data that vary in type and quality across the basin. Most of the surface data were obtained from excellent outcrops in the Madison Bluffs, near the western part of the basin. Five of the eight sections described in the literature are in the bluffs, and five of the six rock samples were collected from there. East of the bluffs, the basin has few outcrops and was evaluated mainly on the basis of data obtained from well logs and from previous geophysical investigations. Deep wells are evenly spaced in the eastern part of the basin and the quality of well logs is good. Geophysical investigations provided additional information about total thickness of the Cenozoic sedimentary sequence and topography of subjacent pre-Tertiary rocks.

\section{BOULDER RIVER BASIN}

Data were obtained from surface studies of 11 localities (P1. 2), analyses of 18 rock samples and 4 water samples from these localities (App. A), 2 published measured sections (App. B), and cited references. 


\section{Favorability Characteristics}

The maximum thickness of the Tertiary sequence, in the southern part of the Boulder River basin, is 1,100 ft (Richard, 1966, Table 1, P1s. 5, 6); the average thickness is less than $1,000 \mathrm{ft}$. The Tertiary rocks lie unconformably on all older rocks, and an unconformity of middle Tertiary age separates 01igocene rocks from Miocene rocks (Richard, 1966, p. 51-54).

Approximately 15 to 30 percent of the sequence is sandstone and conglomerate. Coarse-grained sedimentary rocks average 17 percent ( 30 percent maximum) of the upper Tertiary measured sections and appear to make up a larger percentage of lower Tertiary rocks. Individual sandstone and conglomerate beds are up to $8 \mathrm{ft}$ thick, but most beds are less than $5 \mathrm{ft}$ thick.

Most sandstones are poorly sorted, medium to very coarse grained, feldspathic to arkosic, and along with the conglomerates, generally permeable. The sandstones and conglomerates contain lithic fragments mainly derived from the Elkhorn Mountains Volcanics, assorted intrusive rocks, and to a lesser extent, quartzitic rocks (Weeks, 1974).

Fine-grained rocks in the sequence are composed mostly of glass shards, and thin beds of volcanic ash were found at locality 347. Iron staining was found in localities 346, 347, and 348; and traces of petrified wood and bones were found at locality 346 .

No rock samples from the Tertiary strata contained anomalous equivalent uranium, nor was anomalous radioactivity detected in the Boulder River basin. In addition, none of the water samples analyzed have above average uranium.

The dip of the Tertiary rocks ranges from $0^{\circ}$ to $40^{\circ}$. Dips of about $10^{\circ}$ are most common, but steeper dips are not unusual. Sedimentary rocks at locality 347 exhibit evidence of several feet of post-01igocene movement along one or more normal faults.

The Boulder River basin lies between the Boulder batholith and the highly favorable western Three Forks basin. It extends into and receives drainage from a part of the batholith that has many uranium occurrences. The basin was a conduit for eastward transportation of batholithic detritus during Tertiary time.

\section{Conclusions}

Favorability for uranium deposits in sedimentary rocks of the Boulder River basin is rated poor because the rocks average less than $1,000 \mathrm{ft}$ thick, sandstone percent is low, sandstone and conglomerate beds are thin, and none of the rock and water samples have anomalous uranium. Proximity of the basin to the Boulder batholith and to the highly favorable part of the Three Forks basin is deemed insufficient to justify a higher rating.

Unfortunately, data obtained from surface studies are representative of only a small part of the Tertiary sedimentary rocks. In the northern part of the basin, Tertiary rocks are not exposed (P1. 1) and the thickness of Cenozoic rocks is not known. 
In the southern part of the basin, only rocks of Miocene and Pliocene age are well exposed. 01der Tertiary rocks, which have good favorability in the adjacent Three Forks basin, are poorly exposed and not well represented in the data. The only available subsurface information are thicknesses obtained from geophysical investigations. Consequently, the favorability rating could be applied only to exposures of Tertiary rocks in the southern Boulder River basin.

\section{TOWNSEND AND CLARKSTON BASINS}

\section{Oligocene Rocks}

01der Tertiary rocks crop out in the western part of the Townsend basin, in the northern part of the Clarkston basin, and along the lower part of Sixmile Creek east of Toston. A small wedge of undifferentiated Tertiary rocks (P1. 1) contains some rocks of 01igocene age along its western edge (Nelson, 1963, p. J45). No Eocene rocks were identified in either the Townsend or the Clarkston basins.

Data were obtained from surface studies of seven localities (321, 323, $330,331,355,356,366, \mathrm{P} 1.2$ ), analyses of eight rock samples and one water sample from the study localities (App. A), logs of two water wells (P1. 2) and five uranium exploration drill holes (Fig. I-2), two measured sections described in the literature (APP. B), and cited references.

Favorability Characteristics. In the northern part of the Townsend basin near Winston, 01igocene rocks are more than 2,800 ft thick (Pardee, 1925, p. 27); and in the southeastern part of the basin east of Toston, the Oligocene section may be as much as 2,400 ft (Klemme, 1949, p. 64), or possibly 4,100 ft thick (combined maximum thicknesses of oligocene formation mapped by Robinson, 1967). In the Townsend basin southwest of Toston, Oligocene rocks have a maximum thickness of 1,000 ft (Freeman and others, 1958, p. 507), although the average thickness is much less. Rocks of equivalent age in the northern part of the Clarkston basin are probably less than $250 \mathrm{ft}$ thick (Robinson, 1967, cross section CC').

Geophysical data (Davis and others, 1963; Kinoshita and others, 1964, 1965) indicate that the Townsend basin is shallow southwest of Toston and deepens northward. Cenozoic sedimentary rocks are as much as 6,300 ft thick under the southern part of Canyon Ferry Lake (Lake Sewell) and have a maximum thickness of about $8,500 \mathrm{ft}$ northeast of Winston. The maximum thickness of rocks that are exclusively of oligocene age has not been ascertained.

Potential host rocks are mostly tuffaceous or pumiceous, contain less than 10 percent feldspar, range from medium-grained sandstone to conglomerate, and are poorly to moderately sorted. These rocks average approximately 23 percent of the 01igocene section and generally form beds less than $10 \mathrm{ft}$ thick, although beds exposed along Sixmile Creek east of Toston are 
as much as $70 \mathrm{ft}$ thick (App. B). Although most of the 01igocene beds are relatively impermeable because they are well cemented (loc. 321) or partly clogged with clay (possibly derived from devitrification of volcanic glass), a few beds are clean and permeable (Pardee, 1925, p. 48). Iron staining was found only in locality 330, near Winston.

Organic material is common in the lower part of the section. A few thin 1ignitic coal beds were found east of Toston near Sixmile Creek (Pardee, 1925, p. 23; Robinson, 1967; 1oc. 321). Carbonaceous claystone and siltstone were found near Sixmile Creek (Klemne, 1949, p. 193) and in the Clarkston basin (loc. 355). Northeast of Winston, 1ignites and carbonaceous shales constitute less than 1 percent of the oligocene section; nonetheless, they form beds up to 18 in. thick (Becraft, 1958, p. 154) and are associated with about 20 radioactivity anomalies (Becraft, 1958, p. 155; Fig. I-2; sample 330-2).

Tuffaceous material ranges from 0 to 100 percent and commonly accounts for more than 50 percent of individual beds. Most of the tuffaceous material is fine grained; a significant exception is a thick lens of coarse eruptive volcanic material near Winston (Pardee, 1925, p. 23). This lens is at least 2,700 ft thick (Pardee, 1925, p. 26) and is composed of tuff or tuffaceous material except for a few thin beds of carbonaceous shale and chert (Becraft, 1958, p. 153).

The 0ligocene section rests unconformably on all older rocks. Oligocene rocks are separated from Miocene and younger strata by a disconformity (Pardee, 1925, p. 41; Klemme, 1949, p. 62, 65; Freeman and others, 1958, p. 511, 531; and Robinson, 1967).

The area northeast of Winston contains numerous uranium occurrences (Becraft, 1958, p. 152-159, P1. 3), and secondary uranium minerals (carnotite and metatorbernite) were identified at five localities. According to Becraft (1958, p. 155-159), attempts were made to strip mine uranium from one of the occurrences. Subsurface occurrences may be indicated by 37 radioactivity anomalies recorded on gamma-ray logs from three nearby uranium exploration drill holes (Table I-3; Fig. I-2).

The equivalent uranium contents of the seven bulk rock samples from oligocene strata of the Townsend and Clarkston basins generally are much higher than those from the western and south-central basins (Fig. 3); both the mean equivalent uranium value and the mean eU/eTh ratio of these samples are higher than those of any other sample group in the project (Table 3). Two samples (321-1, 330-2), both lignites, contain anomalously high amounts of equivalent uranium. The other carbonaceous sample (355-1), a claystone, contains $12 \mathrm{ppm}$ equivalent uranium, but its eU/eTh ratio (0.97) is less than 1.0. One carbonaceous sample (321-1) is low in equivalent uranium relative to chemical uranium and may be in disequilibrium (Fig. K-1). The other four samples $(303-1,330-3,330-4,331-1$ ) are from tuffaceous and pumiceous sedimentary rocks. Three are samples of sandstone that is considered to be potential host rock. Although the equivalent uranium content of the four samples is high (mean eU $=17 \mathrm{ppm}$ ), the values 
are attributed to the large proportion of silicic volcanic material in these rocks. The high uranium contents are not believed to be evidence of secondary enrichment in uranium because the eU/eTh ratios of these samples are not correspondingly high. Sample 330-4 is high in equivalent uranium relative to chemical uranium and may be in disequilibrium (Fig. K-1).

Possible disequilibrium indicated by two samples and the obvious concentration of uranium in carbonaceous rocks are evidence of the mobility of uranium in the 01igocene rocks but do not indicate secondary concentration of uranium in the coarser sedimentary rocks which are generally considered to be potential host rocks for uranium deposits. Chemical data indicate that uranium was leached from tuffs and pyroclastic sedimentary rocks and was concentrated in carbonaceous rocks.

The 0ligocene sediments generally dip $15^{\circ}$ to $30^{\circ}$. Normal faults are common in the Tertiary section east of Toston (Pardee, 1925, p. 32, Fig. 4; Klemme, 1949, p. 111-114; Lorenz and McMurtrey, 1956, Fig. 35) and northeast of Winston, along the east side of the Spokane Hills (Mertie and others, 1951, p. 35; Becraft, 1958, p. 154; 1oc. 366).

The Elkhorn Mountains, which separate the Townsend basin from the Boulder batholith to the west, have formed a barrier to eastward drainage from the batholith since early Tertiary time. Detrital material found in outcrops of Tertiary rocks in the basin was not eroded from the batholith but was derived from sources within and immediately adjacent to the basin. For example, 0ligocene sedimentary rocks east of Toston are derived predominantly from Belt Series rocks (Klemme, 1949, p. 64; Robinson, 1967), and the nonvolcanic rocks east and north of Winston are composed of detritus from Elkhorn Mountain volcanics and from pre-Tertiary rocks of the Spokane Hills (Mertie and others, 1951, p. 32, 33; Freeman and others, 1958, p. 510). In most localities, evidence indicates that detritus in the oligocene sedimentary rocks was deposited by easterly-flowing streams.

Conclusions. Favorability for uranium deposits in 0ligocene rocks of the Townsend and Clarkston basins is rated moderate. A favorable sedimentary sequence (Table 1) was not found, and the sandstone and conglomerate show little evidence of secondary enrichment in uranium. Nevertheless, a moderate rating has been assigned because of many uranium occurrences, numerous radioactivity anomalies, and a few uranium minerals in and near the lignites and other carbonaceous beds. Uranium probably was leached from siliceous tuffs and tuffaceous and pumiceous sedimentary rocks and was concentrated in the lignites and other carbonaceous beds. Although permeability of near-surface sandstone and conglomerate is generally low, thick and permeable beds of potential host rocks may be downdip in the deeper parts of the Townsend basin. The possibility of permeable beds in the subsurface and the demonstrated mobility of uranium in 0ligocene rocks suggest that uranium deposits may occur at depth in coarse-textured strata even though no direct evidence of such deposits has been found. 
With the exception of thickness estimates based on geophysical investigations and subsurface radiometric information from uranium exploration drill holes northeast of Winston, little is known of oligocene rocks in the subsurface. These conclusions are, therefore, valid only for outcrops of Oligocene rocks in the Townsend and Clarkston basins.

\section{Miocene and Pliocene Rocks}

Rocks of Miocene and Pliocene age underlie the eastern two-thirds of the Clarkston basin and most of the Townsend basin east of the Missouri River. Rocks of undifferentiated Tertiary age that crop out between Winston and the Missouri River are probably of Miocene and Pliocene age (Freeman and others, 1958, p. 512).

Data were obtained from surface studies of seven localities $(320,322$, $327,328,329,354,381, P 1.2)$, analyses of nine rock samples from the study localities (App. A), two measured sections described in the literature (App. B), and cited references.

Favorability Characteristics. Miocene and Pliocene rocks are predominantly fanglomerate near the east edge of the basin and become finer basinward (Robinson, 1967; Nelson, 1963, p. J41). The rocks also seem to become finer grained downward, although gravel is abundant in the basal $200 \mathrm{ft}$ (Freeman and others, 1958, p. 531). The proportion of sandstone and conglomerate in measured sections ranges from 4 percent (1oc. 328) to 65 percent near the east edge of the basin (sec. 61, App. B). Coarser sedimentary rocks form beds that are generally less than $50 \mathrm{ft}$ thick except near the edge of the basin where the beds are as thick as $470 \mathrm{ft}$ (sec. 61).

Sandstones and gravels, although mostly calcareous, are generally open textured and permeable (Pardee, 1925, p. 48). The sandstones are medium to coarse grained and are moderately to well sorted. Feldspar generally makes up less than 10 percent of the detrital sedimentary rocks. Detrital material in these rocks was predominantly derived from nearby pre-Tertiary rocks in the Big Belt Mountains to the east (Pardee, 1925, p. 24, 26; Klemme, 1949, p. 65, 131; Mertie and others, 1951, p. 37; Ne1son, 1963, p. J42; Robinson, 1967).

The finer-grained rocks are tuffaceous throughout the Miocene and Pliocene section. Traces of fossilized bones were found in two localities and iron staining was found in one locality.

Miocene rocks are as much as $2,000 \mathrm{ft}$ thick in the Clarkston basin, 4,000 ft thick east of Toston, and farther north may be as much as $6,000 \mathrm{ft}$ thick (Robinson, 1967). Miocene and Pliocene sediments lie disconformably on a11 older formations (Pardee, 1925, p. 41; Klemme, 1949, p. 65; Freeman and others, 1958, p. 511; Robinson, 1967). 
of the nine rock samples, only sample 320-1 is anomalously high in equivalent uranium content. The mean equivalent uranium value and the mean eU/eTh ratio are slightly higher in these samples than in those from most of the basins (Table 3). If sample 320-1, which is from a vein of banded chalcedony in siltstone and which is not representative of potential host rocks, is excluded, the mean equivalent uranium value and the mean $\mathrm{eU} / \mathrm{eTh}$ ratio of the remaining samples are lower than those from most of the basins.

Younger Tertiary strata generally dip $10^{\circ}$ to $20^{\circ}$ (Pardee, 1925, p. 31, 32; Freeman and others, 1958, p. 527; Nelson, 1963, p. J49; Robinson, 1967). Normal faulting is common in the Tertiary section east of Toston and at locality 328 .

Conclusions. Favorability for uranium deposits in Miocene and Pliocene rocks in the Townsend and Clarkston basins is rated poor because the rocks contain no known uranium occurrences or radioactivity anomalies; only one sample contained anomalously high concentrations of uranium; and detrital feldspar, iron staining, and reductants are rare.

\section{HELENA BASIN}

The Helena basin (also known as the Prickly Pear basin) is underlain by Tertiary sedimentary rocks that form a benchland in the eastern onethird of the basin. Drilling indicates that these rocks underlie alluvium in the central and western parts of the basin (Pardee and Schrader, 1933).

Outcrops of Tertiary sedimentary rocks between Hauser Lake and Lake Helena are of 0ligocene age (Lorenz and Swenson, 1951, p. 16). The outcrop at locality 322 ( $\mathrm{P} 1.2$ ) is presumed to be of oligocene age because it is lithologically similar to lower Oligocene rocks near Winston.

Data were obtained from surface studies of four localities (P1. 2), analyses of ten rock samples from these localities (App. A), analysis of one water sample from a fifth locality (357), and published reports.

\section{Favorability Characteristics}

Sandstone and conglomerate, which constitute 56 percent of the rocks at locality 359 , form beds that average about $10 \mathrm{ft}$ thick and reach a maximum thickness of more than $40 \mathrm{ft}$. The sandstone ranges from medium to coarse grained and is poorly to very poorly sorted. Artesian and flowing wells indicate that permeability is high in the northern half of the basin where coarser sedimentary rocks commonly lie between impermeable beds. At the south margin of the valley, however, Tertiary beds yield only meager amounts of water (Lorenz and Swenson, 1951, p. 1, 28) and are probably relatively impermeable.

Where not pumiceous, the coarser sediments are feldspathic or arkosic. The finer sediments are tuffaceous throughout the Tertiary section (Lorenz and Swenson, 1951, p. 16; Becraft, 1958, p. 160-161). Petrified 
wood, carbonaceous shale, and lignite are found at localities 359 and 360 . Iron staining is found at all surface study localities, but unit 2 of locality 358 appears to be bleached (reduced?) where the radioactivity is highest.

Tertiary sedimentary rocks between Hauser Lake and Lake Helena are probably less than 1,000 ft thick (Davis and others, 1963, Sheet 1, cross section $\mathrm{AA}^{\prime}$; Burfeind, 1967, P1. 3, cross section KK'), but gradually thicken to the south and rapidly thicken to the west. The deepest part of the basin, 3 to $4 \mathrm{mi}$ north of East Helena, is filled with 4,000 ft (Burfeind, 1967, p. 69) to 6,000 ft (Davis and others, 1963, p. 3) of Cenozoic sediments, most of which are Tertiary in age.

Four uranium occurrences (no. 7, Fig. 1), reported by Becraft (1958, p. 160-161), are radioactivity anomalies in carbonaceous shales that crop out between Lake Helena and Hauser Lake. During this study, several radioactivity anomalies were found in sandstones that were sampled in the same general area.

Equivalent uranium contents of the ten rock samples from the Helena basin are high compared with those of the other basins in the project area (Fig. 3). The mean equivalent uranium content of these samples is the highest of any of the basins (Table 3). Four samples (358-1, 359-3, 359-4, 360-1) from three localities contain anomalously high amounts of uranium. Furthermore, three samples (359-1, 359-3, 360-3) from two localities contain anomalously high concentrations of one or more favorable geochemical indicators.

Oligocene sedimentary rocks generally dip basinward at $8^{\circ}$ to $15^{\circ}$. Between Hauser Lake and Lake Helena, the beds are gently folded along an axis which strikes slightly east of north and plunges gently to the south. Evidence of small-scale faulting in Tertiary beds was observed both at locality 332 and in outcrops between Lake Helena and Hauser Lake.

The Helena basin 1ies immediately north of the Boulder batholith. Prickly Pear and Tenmile Creeks, which flow north into the Helena basin, drain much of the northern third of the batholith where numerous uranium occurrences are located. This north-flowing drainage has probably transported batholithic detritus into the Helena basin since, perhaps, late Eocene time, when the streams unroofed the batholith. The batholithic detritus probably was an important source of the uranium found in 01igocene sedimentary rocks of the Helena basin.

\section{Conclusions}

Favorability for uranium deposits in 0ligocene rocks of the Helena basin is rated good because of the favorable character of the sedimentary rocks, proximity to and drainage from the Boulder batholith, and the presence of several radioactivity anomalies, ample reductant, abundant tuffaceous material, and anomalously high concentrations of uranium in four samples. 
The favorability rating is mainly based upon data collected from the study localities, four of which are clustered in the belt of outcrops between Lake Helena and Hauser Lake (P1. 2). Tertiary rocks are covered by Holocene alluvium in the western two-thirds of the basin and are poorly exposed in the eastern third of the basin. The only useful subsurface data were thickness estimates based upon geophysical investigations. Consequently, the favorability rating is applicable only to exposed or near-surface oligocene rocks.

\section{SILVER CITY BASIN}

The Silver City basin (also known as the Little Prickly Pear basin or the Silver basin) is presumably filled with Tertiary sedimentary rocks that are covered by Holocene alluvium (Pardee and Schrader, 1933, p. 14). No outcrops of Tertiary rocks and no radioactivity anomalies were found. The only available data were from the log of a single water well (P1. 2), which may or may not have penetrated Tertiary rocks. The 168-ft water well penetrated only $3 \mathrm{ft}$ of potential host rocks and bottomed in $4 \mathrm{ft}$ of ash. For these reasons a meaningful favorability rating cannot be assigned.

\section{SMITH RIVER BASIN}

Data were obtained from surface studies of 15 localities (P1. 2), analyses of 7 rock samples and 2 water samples (App. A), logs of 1 water well and 1 petroleum test we11 (P1, 2), and cited references.

\section{Favorability Characteristics}

The Tertiary rocks that underlie the Smith River basin are of Miocene age and are predominantly composed of buff-colored tuffaceous siltstone and vitric tuff. Rhyolitic glass shards, which make up 80 to 85 percent of the rock, appear to have been deposited as ash that was reworked locally by mud flows and streams. The ash was probably derived from volcanic vents in the basin and in the Castle Mountains east of the basin (Koerner, 1939; Tanner, 1949; Wolfe, 1964; Birkholz, 1967; Phelps, 1969).

A few ash-flow tuffs and stream deposits are interbedded with the tuffaceous siltstone and tuff. The ash-flow tuffs are pumiceous and contain high concentrations of uranium. However, the eU/eTh ratio is low and the uranium is believed to be of primary origin. These tuffs are permeable and form beds that average less than $8 \mathrm{ft}$ thick. Although the ash-flow tuffs could serve as potential host rocks, they make up less than $I$ percent of Miocene strata. No evidence of secondary enrichment in uranium was found.

Fluvial deposits are the only other possible host rocks of Tertiary age in the Smith River basin. These rocks, predominantly conglomerate and sandstone, make up less than 5 percent of the outcrops of Miocene age. The conglomerate generally is carbonate cemented in outcrop and forms resistant beds that range from 1 to $27 \mathrm{ft}$ in thickness but that average less than $5 \mathrm{ft}$ thick. Clasts in the conglomerate are derived from 
Precambrian and Paleozoic rocks that crop out in the surrounding mountains. The sandstones are poorly to well indurated, poorly to moderately sorted, medium to very fine grained, and locally calcareous. They form beds that range from 0.5 to $5 \mathrm{ft}$ in thickness.

The sandstones and conglomerates are generally permeable, contain little feldspar, and are not iron stained. No organic material or reductant was found in the coarse-grained rocks, but vertebrate fossils are common in impermeable tuffaceous siltstone and tuff, which make up most of the sequence.

The Miocene section is probably less than $500 \mathrm{ft}$ thick in most parts of the basin but is about $1,000 \mathrm{ft}$ thick in the broadest part of the basin west of the town of White Sulphur Springs (petroleum test wel1 6, App. G; Wolfe, 1964, p. 496; Groff, 1965, p. 13). The Tertiary rocks lie unconformably on all older rocks and are divided by an unconformity of middle Miocene age (Koerner, 1939, p. 1).

Samples 334-1 and 339-1, of potential host rocks, and sample 335-1, of tuffaceous siltstone, all have low equivalent uranium contents and eU/eTh ratios (Fig. 2; Table 3; App. C). Rock sample 335-1, however, contains an anomalously high concentration of niobium (App. E), a favorable geochemical indicator.

Miocene rocks generally dip $3^{\circ}$ to $10^{\circ}$, although Birkholz (1967, p. 28) recorded dips as much as $14^{\circ}$. A few post-Miocene faults are known to cut the Tertiary rocks (Klemme, 1949, p. 50; Birkholz, 1967, p. 46-48).

The Smith River basin contains no Tertiary rocks known to be older than early Miocene age and is far removed from intrusives known to contain significant amounts of uranium.

\section{Conclusions}

Favorability is poor for potential uranium deposits in Tertiary rocks of the Smith River basin. The sedimentary rock sequence is not favorable, no nearby plutonic source of uranium can be identified, and analyses of rock samples reveal low eU/eTh ratios.

Data upon which the rating is based are mostly derived from the northern part of the basin (P1. 2). Outcrops are rare and very small elsewhere in the basin. However, other geologic studies (McGrew, 1974a, 1974b, $1974 \mathrm{c}, 1974 \mathrm{~d}$ ) indicate that Miocene rocks in the southern part of the basin are thin and do not significantly differ in character from those in the northern part. 


\title{
SOUTH-CENTRAL BASINS
}

\author{
by
}

J. W. Robins

The south-central part of the project area has 14 basins (Fig. 4), which are discussed in an approximate north-to-south order. Some basins have been grouped together for discussion.

JEFFERSON RIVER, BEAVERHEAD RIVER, AND LOWER RUBY RIVER BASINS

Tertiary rocks in the Jefferson River, Beaverhead River, and Lower Ruby River basins are the best exposed and the most completely studied rocks of the south-central basins. In addition, the Tertiary section is thick; geophysical investigations indicate that the maximum thickness of Cenozoic basin deposits is about 4,000 ft in the Beaverhead River and Lower Ruby River basins, is between 4,000 and 5,500 ft in the Jefferson River basin, and increases to $7,800 \mathrm{ft}$ at the junction of the three basins south of Twin Bridges (Burfeind, 1967, p. 51-54). The following favorability discussions are organized on the basis of recently established age subdivisions for Tertiary rocks in these basins.

Eocene and O1igocene Rocks

Eocene and Oligocene sedimentary rocks in the Jefferson River, Beaverhead River, and Lower Ruby River basins were called the Renova Formation and mapped by Kuenzi and Fields (1971), Petkewich (1972), and Hoffman (1972). Data were obtained from surface studies of 8 localities (201, 203, 205, 206, 219, 224, 230, 231, P1. 2), analyses of 12 rock samples from these localities (App. A), a lithologic $\log$ of 1 petroleum test wel1 (no. 9, App. G, P1. 2), 15 measured sections described in the literature (App. B), and cited references.

Favorability Characteristics. Rocks of the lower Tertiary sequence have a maximum stratigraphic thickness of $3,500 \mathrm{ft}$ in the Jefferson River basin (Kuenzi and Fields, 1971, p. 3385) and 2,400 ft in the Lower Ruby River basin (Petkewich, 1972, p. 24). In the northern part of the Beaverhead River basin, a petroleum test we11 (no. 9, App. G) penetrated 1,725 ft of sedimentary rocks that are believed to be of Eocene and 0ligocene age. Angular unconformities bound the sequence above and below.

Estimations of sandstone percent for the rocks in this group of basins are: less than 30 percent in the Jefferson River basin (Kuenzi and Fields, 1971, p. 3379), 18 percent in the Lower Ruby River basin (Petkewich, 1972, p. 30), 25 percent in part of the Beaverhead River basin (Hoffman, 1972, p. 19), and 28 percent in petroleum test well 9. The lower Tertiary section also contains fine-grained permeable sandstones that are not represented in the estimated sandstone percent values.

Potential host rocks range from medium-grained sandstone to conglomerate. The rocks are generally arkosic or feldspathic, are poorly sorted, and form beds that average about $19 \mathrm{ft}$ in thickness and range from 0 to $47 \mathrm{ft}$ thick. 


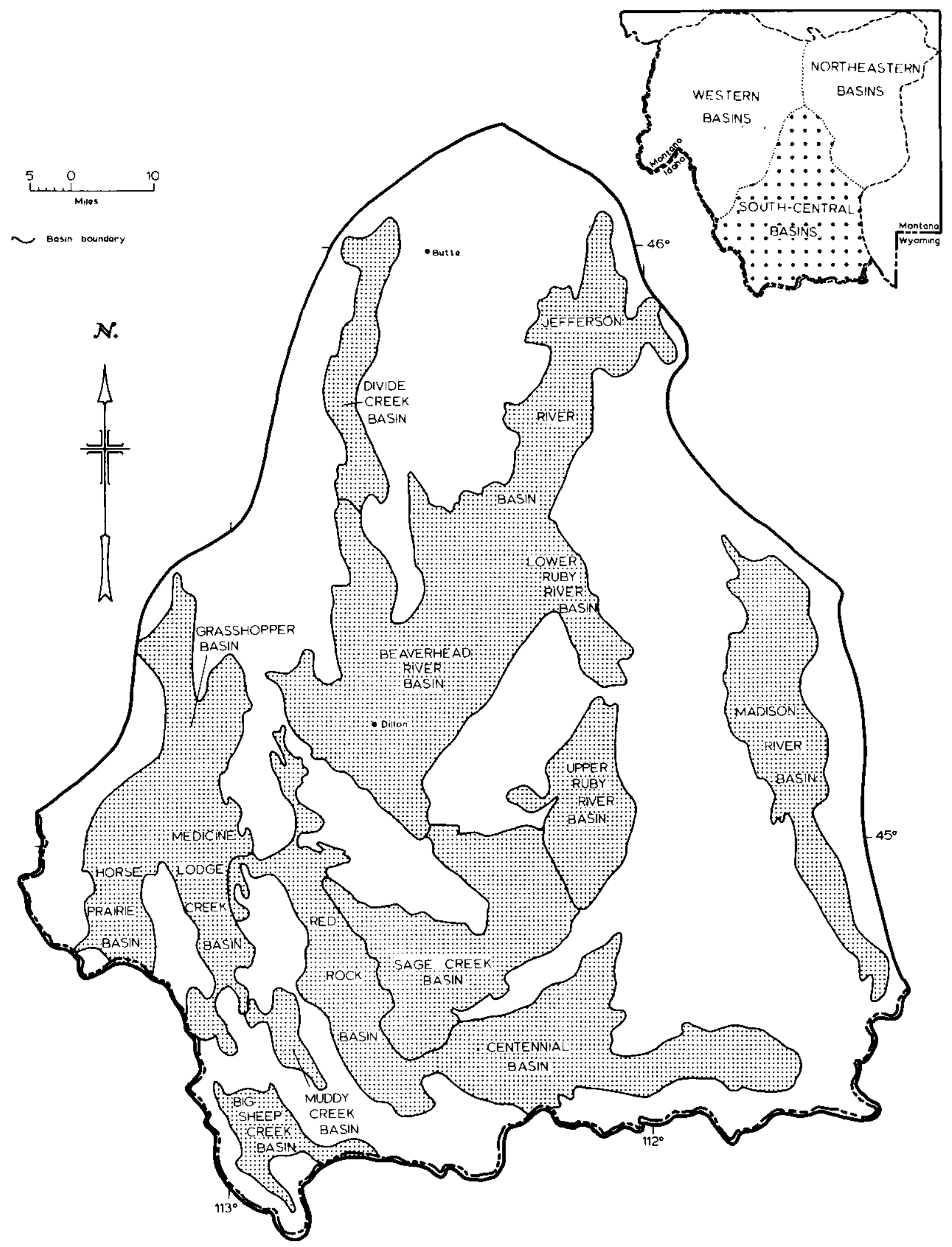

Figure 4. Locations and names of Tertiary basins in the south-central part of the study area. 
In some areas the beds are permeable and in most areas the beds are iron stained. Carbonaceous material was found in trace amounts at two localities. Tuffaceous rocks commonly overlie the potential host rocks.

One uranium occurrence (no. 4, Fig. 1; 1oc. 205, P1. 2) is known in this group of basins. No uranium minerals were identified at this occurrence.

The mean equivalent uranium content $(5.3 \mathrm{ppm})$ of the rock samples from the three basins (excluding volcanic samples 224, 250, 231, App. A) is more than one standard deviation higher than the mean content (2.9 ppm, Fig. 3) of all rock samples from the south-central basins. Two samples (205-2, 219-1, Fig. 5) contain anomalous equivalent uranium. These values are supported by higherthan-average (more than one standard deviation above mean) concentrations of gallium, lithium, and yttrium in sample 205-1, and an anomalous (more than two standard deviations above mean) amount of vanadium in sample 219-1 (App. E).

The uraniferous Boulder batholith is the major source of sediment for the Tertiary rocks in the northern part of the Jefferson River basin. Tertiary sedimentary rocks in the southern part of the Jefferson River basin and in the Lower Ruby River and Beaverhead River basins are derived mainly from gneisses and schists of Archean age which have a lower mean uranium content than the granitic rocks of the Boulder batholith.

Conclusions. The favorability for uranium deposits in Eocene and Oligocene rocks in the Jefferson River, Beaverhead River, and Lower Ruby River basins is rated moderate because the sandstone content is adequate, both the characteristics of the potential host rocks and the chemical characteristics are favorable, and carbonaceous material is present. The lower Tertiary rocks are more favorable in the northern Jefferson River basin than in the remainder of the southcentral basins. Paleodrainage in the northern part of the basin was from the Boulder batholith, which has an unusually high number of uranium occurrences. In the remainder of these basins, the paleodrainage was from Precambrian schists and gneisses, which are less favorable as source rocks than the batholith.

\section{Miocene and Pliocene Rocks}

Kuenzi and Fields (1971) named the Miocene and Pliocene rocks in the Jefferson River basin the Sixmile Creek Formation. Data were obtained from surface studies of 12 localities $(202,204,214-218,220,237,259-261$, P1. 2), analyses of 15 rock samples and 2 water samples from these localities (App. A), logs of 2 water wells and of 2 petroleum test wells (nos. 9, 10, P1. 2), 13 measured sections described in the literature (App. B), and cited references.

Favorability Characteristics. The maximum stratigraphic thickness of Miocene and Pliocene rocks is estimated to be 2,400 $\mathrm{ft}$ in the Jefferson River basin (Kuenzi and Fields, 1971, p. 3385) and 3,100 ft in the Lower Ruby basin (Petkewich, 1972, p. 59). Neither water wells nor petroleum test wells penetrated more than $558 \mathrm{ft}$ of these rocks.

Sandstone and conglomerate constitute approximately 79 percent of the Miocene and P1iocene sequence in the Jefferson River basin (Kuenzi and Fields, 1971, p. 3383) and 78 percent in the Lower Ruby River basin (Petkewich, 1972, p. 62-63). Tuffaceous material generally is present throughout the section. 


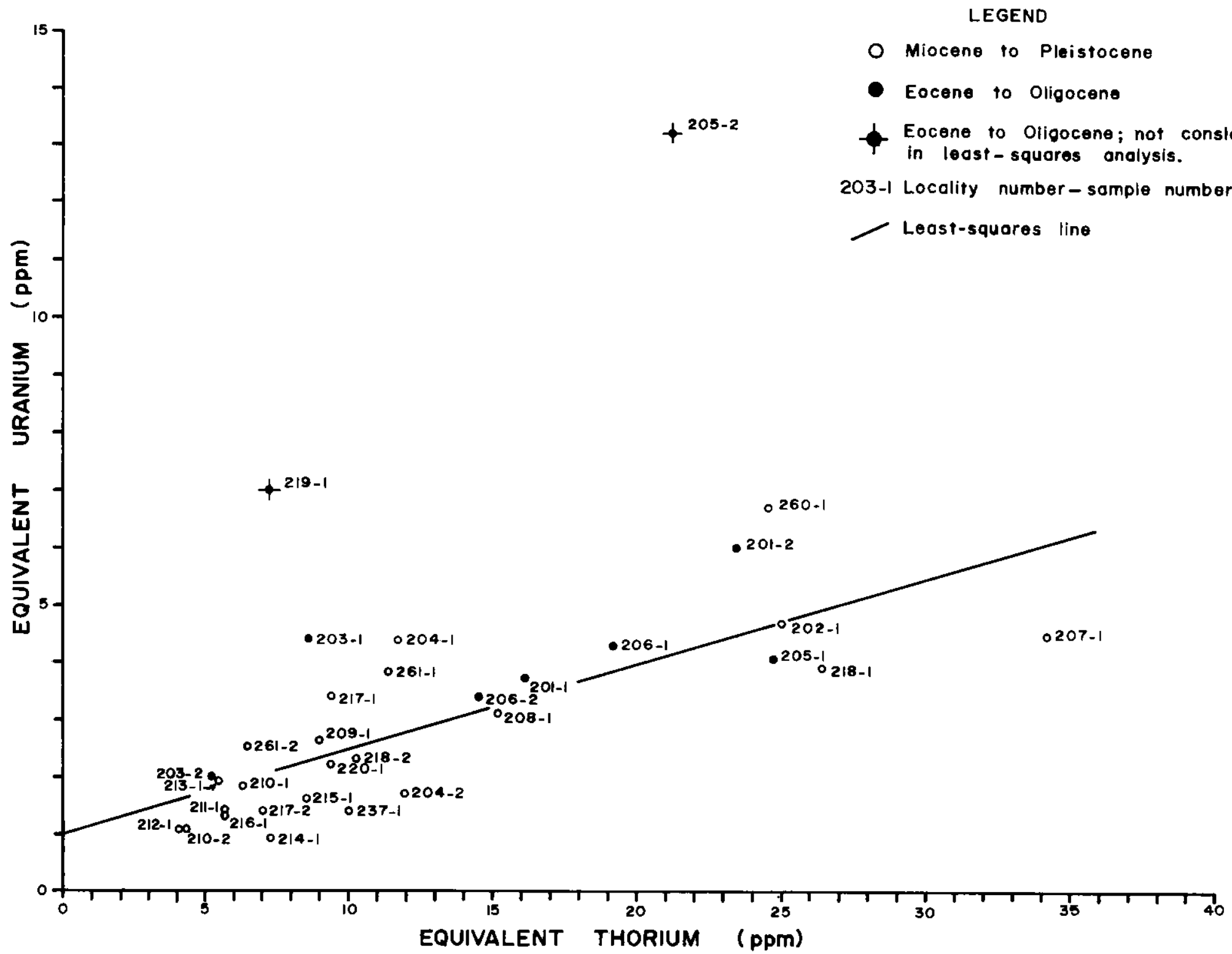

Figure 5. Plot of equivalent uranium versus equivalent thorium for samples from selected central basins. (Includes samples from Jefferson River, Beaverhead River, Lower Ruby River, and Divide Creek basins; excludes volcanic samples $224-1,230-1$, and 231-1) 
Potential host rocks are medium-grained sandstone to conglomerate, feldspathic or arkosic in most localities, predominantly poorly sorted, and very permeable. (In fact, the Sixmile Creek Formation may be too permeable to have impeded any fluids that may have moved through it, and few permeability barriers bound the potential host rocks.) The potential host rocks have relatively low dips, which average $10^{\circ}$ (Kuenzi and Fields, 1971, p. 3385).

Trace amounts of carbonaceous material were found in two localities and were reported in one published measured section.

Chemical data yield no positive indications of favorability. Equivalent uranium contents of two samples (204-1, 260-1) are slightly high relative to equivalent thorium, when compared to the contents of all other samples in the sample group (Fig. 5). Sample $260-1$ is high in equivalent uranium primar1ly because of abundant tuffaceous detritus. Water sample 259-1, from the same vicinity as sample 260-1, has a $\mathrm{U}_{3} \mathrm{O}_{8}$ value of $10 \mathrm{ppb}$. Although this is the highest value obtained from a water sample in the south-central basins, it is not considered anomalously high when compared to the mean (7 $\mathrm{ppb}$ ) of all samples (App. F).

The Boulder batholith supplied most of the detrital sediments deposited in the northern Jefferson River basin during Miocene and Pliocene time. The southern Jefferson River basin, the Lower Ruby River basin and the Beaverhead River basin, however, received detrital sediments from gneisses and schists of Archean age.

Conclusions. Favorability for uranium deposits in Miocene and Pliocene rocks in the Jefferson River, Beaverhead River, and Lower Ruby River basins is rated poor because the rocks are very permeable, are mostly sandstone, have no positive chemical indicators, and contain little carbonaceous material.

\section{Pliocene and Pleistocene Rocks}

Data were obtained from surface studies of four localities $(207,211$, 212 , 213, P1. 2), analyses of four rock samples from these localities (App. A), one petroleum test well $\log$ (no. 11, P1. 2), and cited references.

Because deposition was continuous from Miocene to Pleistocene time in the Jefferson River and contiguous basins, the Pliocene-Pleistocene boundary cannot be readily delineated; therefore Pliocene and Pleistocene rocks are treated here as one sequence. The Pliocene-Pleistocene sedimentary sequence is unconsolidated and very permeable; uranium-bearing solutions would have passed directly into underlying rocks. The average uranium values of samples from three localities is less than 2 ppm (1ocs. 211, 212, 213; App. C). A sample from locality 207 (P1. 2) has an equivalent uranium content of $4.5 \mathrm{ppm}$, but the unusually high equivalent thorium content ( $34.3 \mathrm{ppm}$ ) indicates a probable local concentration of heavy minerals. On the basis of these findings, the favorability for uranium deposits in these rocks is rated poor. 
Data were obtained from surface studies of three localitics (P1. 2), analyses of four rock samples from these localities (App. A), logs of two water wells (P1. 2), and cited references.

Tertiary sedimentary rocks in the Divide Creek basin are predominantly of Miocene and Pliocene age (Smedes, 1967). Oligocene rocks crop out locally along the western edge of the basin ( $R$. W. Fields, 1976, personal commun.) and may underlie most of the younger Tertiary sequence.

\section{Favorability Characteristics}

Basin-fill deposits are indicated by geophysical investigations to be at least 2,800 ft thick (Burfeind, 1967, P1s. 1, 2, cross section GG'). The $400 \mathrm{ft}$ of deposits penetrated by the two water wells contains about 25 percent sandstone and conglomerate. Potential host rocks at two localities range from medium-grained sandstone to conglomerate and are poorly sorted, feldspathic, permeable, and iron stained. Detrital material in a third locality (210) is primarily limestone and quartzite. Possible host rocks form beds that are generally 5 to $10 \mathrm{ft}$ thick and rarely more than $20 \mathrm{ft}$ thick. Tuffaceous material is interbedded with the potential host rocks. The Tertiary rocks examined contain no reductants and, because few impermeable barriers are above or below the beds of potential host rocks, are generally too permeable to have retained uraniferous fluids. The average equivalent uranium content $(2 \mathrm{ppm})$ of rock samples from the Divide Creek basin is below the mean $(2.9 \mathrm{ppm})$ for all rock samples from the southcentral basins. No anomalous uranium values were found (Fig. 5).

\section{Conclusions}

Favorability for uranium deposits in Tertiary rocks of the Divide Creek basin is rated poor because the rocks are too permeable, contain no reductants, and have no favorable chemical indicators. The data upon which the rating is based represent only the upper few hundred feet of Miocene and Pliocene rocks in the basin. In neighboring basins, Eocene and oligocene rocks are more favorable than younger Tertiary rocks. Although the presence of 01igocene sedimentary rocks in the basin and the proximity of the basin to the Boulder batholith both enhance the favorability rating, the available evidence is not adequate to warrant a rating of moderate.

\section{UPPER RUBY RIVER BASIN}

The Upper Ruby River basin contains Tertiary sedimentary rocks that range in age from Paleocene to $\mathrm{Pliocene.} \mathrm{The} \mathrm{rocks} \mathrm{have} \mathrm{a} \mathrm{maximum} \mathrm{total}$ thickness of $7,000 \mathrm{ft}$ (Burfeind, 1967, p. 71), are cut by post-Tertiary

a/ Locality 241 in this basin contains rocks of Upper Cretaceous and Paleocene age and is discussed with the rocks of this age range in the section on the Red Rock and Centennial basins. 
faults near the edges and the center of the basin, and dip $0^{\circ}$ to $15^{\circ}$. Although these rocks are subdivided on the basis of age for the following discussion, the maximum thickness of the rocks in each subdivision has not been determined.

Eocene and 01igocene Rocks

Sedimentary rocks of Eocene and Oligocene age were named the Passamari Formation by Dorr and Wheeler (1964). Data were obtained from surface studies of one locality (242, P1. 2), analyses of two rock samples from this locality (App. A), logs of two uranium exploration drill holes (nos. 19, 21, Fig. I-3), one measured section described in the literature (sec. 38, App. B), and published reports.

Favorability Characteristics. Exposures of the Passamari Formation are predominantly composed of lacustrine sediments. Sandstone content of these rocks is low. The few potential host rocks in outcrops of the formation are medium-grained sandstones that are moderately sorted, permeable, and commonly iron stained. They form beds that range from 2 to $13 \mathrm{ft}$ in thickness. Traces of carbonaceous material are found in both fine- and coarse-grained sedimentary rocks, and tuffaceous beds overlie beds of potential host rocks. Although no feldspar was found in outcrop, two beds of medium-grained feldspathic sandstone, each approximately $20 \mathrm{ft}$ thick, were identified from examination of drill cuttings from the interval between 300 and $450 \mathrm{ft}$ in uranium exploration test well 21 (Fig. I-3).

No anomalous chemical values were found in the two rock samples collected from locality 242 (samples 242-1, 242-2, Fig. 6), but a highly anomalous radioactive interval was detected in the gamma-ray $10 \mathrm{~g}$ of uranium exploration drill hole 21 (Table I-4). The anomalous interval may not be representative of the subsurface portions of the Passamari. Formation throughout the basin, however, because hole 21 is near a late Cenozoic rhyolite plug, which may have caused the alteration and secondary enrichment in uranium of the adjacent upper Tertiary sedimentary rocks.

The Passamari Formation was deposited unconformably on all older rocks. Detrital sediments in the formation were derived from Precambrian gneiss and schist, which surround the Upper Ruby River basin. These Precambrian rocks have a low uranium content (mean $\mathrm{eU}_{3} \mathrm{O}_{8}$ content $=2.1 \mathrm{ppm}$, Malan and Sterling, 1970, Table 6) and are not favorable sources for uranium.

Conclusions. Favorability for uranium deposits in outcrops of the Passamari Formation (Eocene and 01igocene) of the Upper Ruby River basin is rated poor because the sandstone content is low and no favorable chemical indicators were identified. An anomalously radioactive interval and some feldspathic beds, which are found in the subsurface and which normally indicate favorability, are not deemed sufficient to raise the favorability rating. 


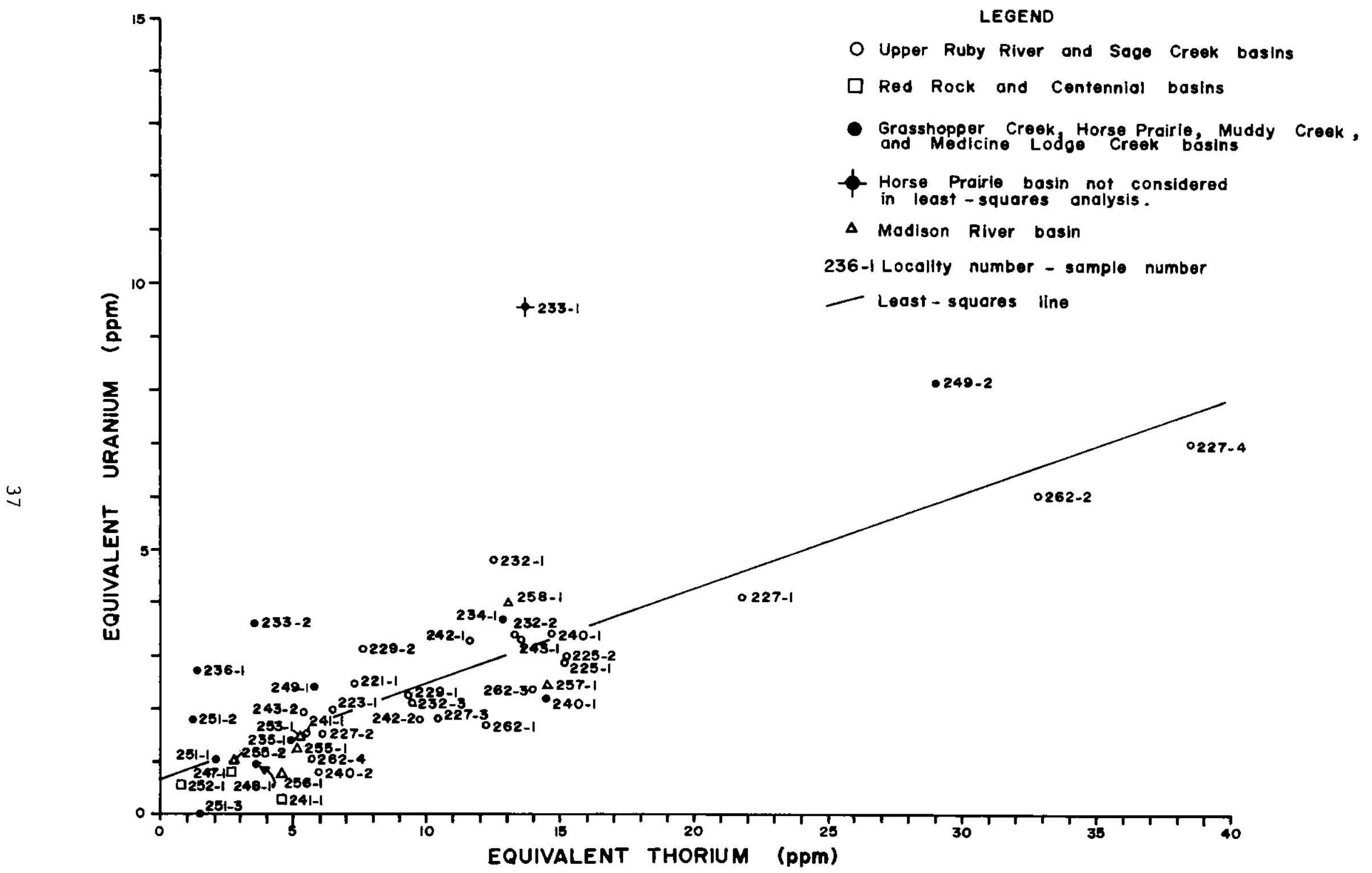

Figure 6. Plot of equivalent uranium versus equivalent thorium for samples from selected southern basins. (Includes samples from Upper Ruby River, Sage Creek, Red Rock, Centennial, Grasshopper Creek, Horse Prarie, Medicine Lodge Creek, Muddy Creek, and Madison River basins; excludes hydrothermally-altered samples and samples of probable volcaniclastic origin [222-1, 238-1, $239-1,245-1-250-1$, and 254-1]) 
Miocene and P1iocene Rocks

Miocene and Pliocene sedimentary rocks in the Upper Ruby River basin were called the "Madison Valley equivalent" by Dorr and Wheeler (1964, p. 308). Data were obtained from surface studies of six localities (221, 222, 223, $238,239,240, \mathrm{P} 1.2$ ), analyses of seven rock samples from these localities (App. A), logs of eight uranium exploration drill holes (nos. 15-18, 20, 22-24, Fig. I-3), four measured sections described in the literature (secs. 37, 39-41, App. B), and published reports.

Favorability Characteristics. Potential host rocks range from mediumgrained sandstone to conglomerate, which together make up 38 percent (lower member of the Madison Valley equivalent, sec. 39, App. B) to 83 percent of the Miocene and Pliocene sections. The sandstones contain little feldspar, are poorly sorted and permeable, and, along with the conglomerates, are iron stained in some places. Many potential host rock beds are more than $20 \mathrm{ft}$ thick. Impermeable barriers are present between some sandstone and conglomerate beds. Tuffaceous material is abundant in the upper member of the Madison Valley equivalent (Dorr and Wheeler, 1964, p. 305), and carbonaceous material was found between the depths of 600 and $635 \mathrm{ft}$ in uranium exploration drill hole 15.

One uranium occurrence (no. 8, Fig. 1) and four surface radioactivity anomalies (Fig. I-3) have been reported for these rocks. Four subsurface radioactivity anomalies were recorded on gamma-ray logs of uranium exploration drill holes 16,20 , and 23 (Table $I-4$ ).

Miocene and Pliocene sedimentary rocks are altered near their contact with rhyolite and basalt extrusives of post-early Pliocene age. The uranium occurrence, two study localities at the occurrence $(222,238)$, and one locality nearby (239) are within the zone of alteration. Although all three rock samples from these localities contain anomalously high amounts of uranium (up to $107 \mathrm{ppm} \mathrm{eU),} \mathrm{the} \mathrm{data} \mathrm{from} \mathrm{these} \mathrm{samples} \mathrm{are} \mathrm{not}$ considered representative of the Miocene and Pliocene rocks in the Upper Ruby River basin and were not used to evaluate favorability. Other samples from the Madison Valley equivalent contain no anomalous chemical values.

Conclusions. Favorability for uranium deposits in Miocene and Pliocene rocks in the Upper Ruby River basin is rated moderate because the sand percent is favorable, potential host rocks are present, and a few surface and subsurface radioactivity anomalies have been reported.

\section{SAGE CREEK BASIN}

Tertiary sedimentary rocks in the Sage Creek basin range from Eocene to Pliocene in age, but, because of their similarity, they are treated as a group in the following discussion. Data were obtained from studies of 7 localities ( $P 1.2$ ), analyses of 18 rock samples and 2 water samples from the study localities (App. A), logs of 2 water wells (P1. 2), 1 measured section described in the literature (sec. 42, App. B), and pub1ished reports. 


\section{Favorability Characteristics}

The maximum aggregate thickness of the three Tertiary formations mapped in the Sage Creek basin by Scholten and others (1955, P1. 1, p. 369) is $3,400 \mathrm{ft}$. The total thickness of these rocks in any single place within the basin is unknown. Neither of the two water wells completely penetrates the Tertiary section.

Potential host rocks are conglomerates and medium- to coarse-grained sandstones that make up 10 to 61 percent of the Tertiary section. Individual beds generally are more than $20 \mathrm{ft}$ thick and commonly are iron stained. Siltstones predominate in the lower Tertiary section.

Tuffaceous material was found above potential host rocks throughout the sequence and is most abundant in Miocene and Pliocene sedimentary rocks. Trace amounts of carbonaceous material were found at two localities. None of the sources of detrital sediments are granitic.

Four rock samples contain more than $4 \mathrm{ppm}$ equivalent uranium. Only sample 232-1 is high in equivalent uranium compared to equivalent thorium (Fig. 6). The sample was collected from a locality adjacent to the rhyolitic Cook Ranch volcanics of Oligocene age (Scholten and others, 1955, P1. 1) and may be slightly enriched in uranium but is not anomalous. Samples 227-1, 227-4, and 262-2 are tuffaceous sandstones and contain relatively high levels of both thorium and uranium (Fig. 6). The uranium and thorium contents of these three samples probably result from a high content of silicic volcanic detritus in the sandstones and are not evidence of secondary enrichment in uranium.

\section{Conclusions}

Favorability for uranium deposits in Tertiary rocks of the Sage Creek basin is rated poor. Although the sandstone percent is favorable and potential host rocks are present, the poor rating is assigned because granitic source rocks, anomalously high equivalent uranium values, and uranium occurrences are lacking in the basin and reductants are scarce.

\section{RED ROCK AND CENTENNIAL BASINS}

Data were obtained from surface studies of two localities (P1. 2), analyses of two rock samples from the study localities (App. A), and cited references.

The central parts of the Red Rock and Centennial basins are covered by a thick sequence of unconsolidated Quaternary sediments (P1. 1). The only Tertiary sedimentary rock known to crop out in the basins is the Beaverhead Conglomerate of Late Cretaceous to early Eocene age (Lowell and Klepper, 1953).

The Beaverhead Conglomerate has poor favorability for uranium deposits. This formation has an estimated thickness of 9,700 ft (Lowe11 and Klepper, 1953, p. 238). Seventy-three percent of the formation consists of quartzite and limestone conglomerates; the remainder is limestone, siltstone, and 
sandstone. The conglomerate, sandstone, and siltstone are all strongly cemented, generally dark red, and contain no known reductants. The bedding generally is massive, and the formation has undergone considerable deformation. The mean equivalent uranium content of two samples from these basins and one sample of the Beaverhead Conglomerate (the "Red Conglomerate" of Dorr and Wheeler, 1964, p. 302) from the Upper Ruby River basin was $0.6 \mathrm{ppm}$ (Table 3; Fig. 6). This is more than one standard deviation below the mean (2.9 ppm) for all samples from the south-central basins.

GRASSHOPPER CREEK, HORSE PRAIRIE, MEDICINE LODGE CREEK, AND BIG SHEEP CREEK BASINS

Rocks in the Grasshopper Creek, Horse Prairie, Medicine Lodge Creek, and Big Sheep Creek basins were named the "Medicine Lodge" beds by Scholten and others (1955). Data were obtained from surface studies of seven localities (P1. 2), analyses of nine rock samples from the study localities (App. A), logs of three water wells and one petroleum test well (P1. 2), two measured sections described in the literature (App. B), and cited references.

The favorability discussion and conclusions apply to most of the Miocene and Pliocene sedimentary section in the Horse Prairie and Medicine Lodge Creek basins. The conclusions are less applicable to the Grasshopper Creek and Big Sheep Creek basins because information is 1imited for these areas. The four basins, which are contiguous and contain rocks of similar age, are discussed as a group.

\section{Favorability Characteristics}

The estimated maximum thickness of the Tertiary rocks ranges from 4,130 to $6,700 \mathrm{ft}$ (M'Gonigle, 1965, p. 50; petroleum test wel1 12, App. G). The sandstone content in these rocks ranges from 4 to 10 percent overall (secs. 43, 44, App. B; petroleum test well 12, App. G). Lower portions of the sections may contain as much as 60 percent sandstone and conglomerate (loc. 233, App. A; water well 39, App. H). Nearby granitic rocks, such as the Dillon Granite Gneiss which underlies the upland between the Horse Prairie and Medicine Lodge Creek basins (M'Gonigle, 1965, P1. 1), and the quartz monzonitic pluton which underlies the Pioneer Mountains to the north (Myers, 1952, P1. 1), provided detritus for Tertiary sedimentary rocks in these basins.

Potential host rocks in beds greater than $20 \mathrm{ft}$ thick were found in several localities (App. A) and were described in published measured sections (App. B) and in water well logs (we1ls 38, 39, 40, App. H). These rocks are conglomerates and medium- to coarse-grained sandstones that are poorly sorted, permeable, and iron stained. Most of these rocks are arkosic or feldspathic. Medicine Lodge shale beds above the potential host rocks contain abundant carbonaceous material, and some carbonaceous material is present within the possible host beds. Tuffaceous rocks were mapped on the west side of Medicine Lodge Creek basin by M'Gonigle (1965, P1. 1) and were studied at locality 267. Tuffaceous detritus is a constituent of the potential host rocks. 
One uranium occurrence (no. 9, Fig. 1; 1oc. 250, P1. 2) is reported for the Horse Prairie basin. Sample 250-1, from this locality, is a volcanic tuff that contains anomalous equivalent uranium (26.6 ppm), although no uranium minerals were identified. Sample 233-1 is anomalously high in equivalent uranium (Fig. 6). (Sample 250-1 is excluded from consideration because of 1ts volcanic origin.) Samples $236-1$ and $249-2$ contain higher-than-average equivalent uranium accompanied by anomalous concentrations of other chemical indicators (lead and tin in sample 236-1, manganese in sample 249-2). One other sample (233-2) contains higher-than-average equivalent uranium.

Miocene and Pliocene rocks lie unconformably on the older Tertiary strata. The Tertiary section is cut by minor faults.

\section{Conclusions}

The Tertiary section as a whole has moderate favorability for uranium deposits because of the presence of potential host rocks, carbonaceous material, favorable chemical characteristics, and nearby favorable source rocks. The lower part of the section contains more potential host rocks than the upper and is, therefore, considered to be more favorable.

\section{MUDDY CREEK BASIN}

Data were obtained from surface studies at three localities (P1. 2), analyses of five rock samples collected from the study localities (App. A), and the cited references. Only the upper portion of the Tertiary sedimentary rocks in the basin were studied.

Rocks in the Muddy Creek basin are of Oligocene age and were called the "Muddy Creek" beds by Scholten and others (1955, p. 369). The rocks have a maximum thickness of more than 1,000 ft (Scholten and others, 1955, p. 369). Potential host rocks are conglomerates and medium- to coarsegrained sandstones that are permeable, iron stained, and form beds greater than $20 \mathrm{ft}$ thick in one locality (1oc. 251). The fine-grained sedimentary rocks contain some carbonaceous material (1oc. 246) and thick beds of tuff crop out in the basin (1oc. 245). Most of the section, however, consists of fine-grained sandstone, siltstone, and mudstone. The sandstones are neither feldspathic nor arkosic, no favorable chemical indicators were found in rock samples (except sample 245-1, which is excluded because of its volcanic origin), and no granitic source rocks are nearby.

Tertiary sedimentary rocks of the Muddy Creek basin have poor favorability for uranium deposits because sandstone content is low, chemical characteristics are unfavorable, and both granitic source rocks and known uranium occurrences are lacking.

\section{MADISON RIVER BASIN}

Data were obtained from surface studies of six localities (P1, 2), analyses of seven rock samples from the study localities (App. A), logs of three water wells (P1. 2), and the cited references. 
The Tertiary sedimentary sequence in the Madison River basin consists of a poorly exposed basal gravel of 0ligocene age overlain by a thick sequence of volcanic flows and tuffs, freshwater limestone of Miocene and Pliocene age, and a thick cover of Pleistocene gravel and sand (Hadley, 1969a; 1969b). Samples show no anomalous chemical characteristics.

The basin has a maximum depth of $5,000 \mathrm{ft}$, on the basis of geophysical data presented by Burfeind (1967, p. 66). Information from three water wells is available for only the upper few hundred feet of the total section. We11 300 penetrated $193 \mathrm{ft}$ of strata, we11 37 penetrated $105 \mathrm{ft}$ before bottoming in limestone, and well 50 penetrated material described as "ash" from 88 to $188 \mathrm{ft}$ and continued to $339 \mathrm{ft}$ in "clay" of unknown age.

On the basis of limited information, Tertiary sedimentary rocks of the Madison River basin have poor favorability for uranium deposits. None of the samples contain anomalously high equivalent uranium values, no uranium occurrences are known, and no reductants were seen in the exposed section. However, owing to the large size of the basin, the possible widespread existence of the lower Tertiary sequence in the subsurface, and regional geologic similarities to other favorable basins, the Madison River basin may be more favorable than the data indicate. Much more subsurface information is required to adequately evaluate the favorability. 
WESTERN BASINS

by

W. E. Curry

The 13 basins (Fig. 7) in the western part of the project area are discussed in an approximate east-to-west order. Several smaller basins are grouped for discussion.

DEER LODGE BASIN

Data were obtained from surface studies of 12 localities (P1. 2), analyses of 22 rock samples from these localities (App. A), the log of one petroleum test we11 (P1. 2), and the cited references. Tertiary sedimentary rocks in the Deer Lodge basin range from Eocene to Pliocene in age (Konizeski and others, 1968 , P1. 1) but, with few exceptions, are not subdivided by age for discussion of favorability.

\section{Favorability Characteristics}

According to gravity profiles, the maximum thickness of valley fill ranges from 2,300 ft near the town of Deer Lodge to more than 5,500 ft in the southern part of the basin (Konizeski and others, 1968, p. 29). Thickness in the centra1 part of the basin interpreted from gravity data is substantiated by petroleum test well 8 , which penetrated $2,516 \mathrm{ft}$ of Tertiary strata without reaching the underlying pre-Tertiary rocks. The section penetrated by petroleum test wel1 8 contains 23 percent sandstone and conglomerate; at locality 150 the section is entirely conglomerate.

Potential host rocks range from medium-grained sandstone to conglomerate. The rocks are feldspathic or arkosic, iron stained in many areas, and poorly sorted. They vary in permeability and form beds that average less than $20 \mathrm{ft}$ thick and have a maximum thickness of $81 \mathrm{ft}$ (loc. 106). Minor to trace amounts of carbonaceous material are present in the sandstones and conglomerates and in adjacent fine-grained beds.

Tertiary sedimentary rocks in the Deer Lodge basin contain volcanic detritus eroded from the Lowland Creek Volcanics and some interbedded volcanic ash (Konizeski and others, 1968, p. 14-16).

The mean equivalent uranium content $(3.2 \mathrm{ppm})$ for the samples from the Deer Lodge basin is close to the mean for all samples from the western basin sample group (Fig. 3). Sample 101-1 contains anomalous equivalent uranium relative to equivalent thorium (Fig. 8). Sample 106-1 contains a higher-than-average enrichment of equivalent uranium relative to equivalent thorium (Fig. 8) as well as anomalous concentrations of $\mathrm{Cu}, \mathrm{Mn}, \mathrm{Sn}, \mathrm{V}$, and $\mathrm{Zn}$ (App. E).

The Deer Lodge basin is fault-bounded (Konizeski and others, 1968, p. 27-29, P1. 2) and thus is similar to other large fault-bounded basins in which the favorable lower sequence has been preserved in the subsurface. Most of the 


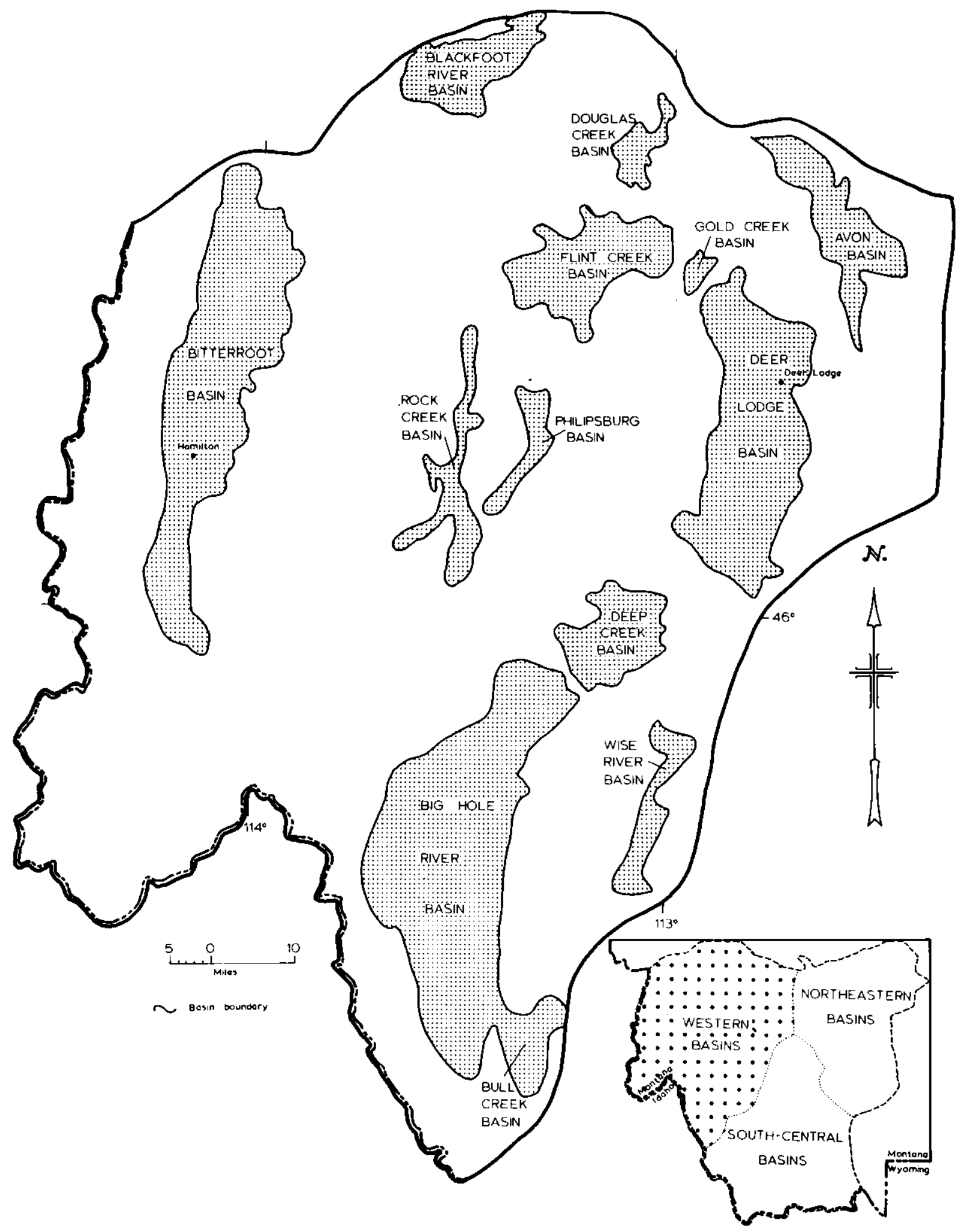

Figure 7. Locations and names of Tertiary basins in the western part of the study area. 


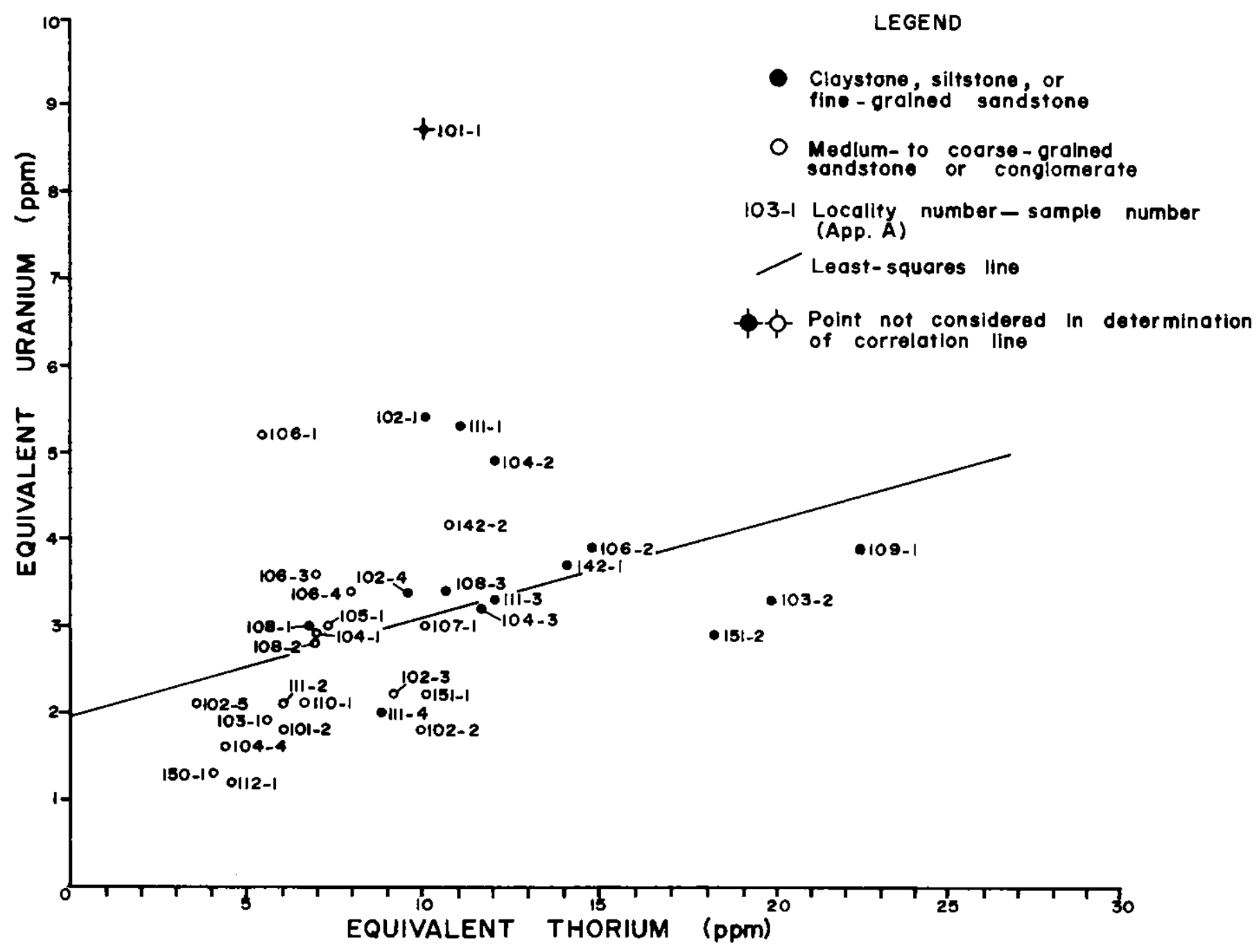

Figure 8. Plot of equivalent uranium versus equivalent thorium for samples from the Deer Lodge, Flint Creek, and Gold Creek basins. 
Tertiary sedimentary strata dip gently except in the western part of the basin where they are deformed by folding and faulting (Konizeski and others, 1968, p. 15-25).

The basin is adjacent to the uraniferous Boulder batholith. The batholith may have been a source of both sediment and uranium for Tertiary rocks in the Deer Lodge basin.

\section{Conclusions}

A rating of moderate favorability for uranium deposits is assigned to the Tertiary sedimentary sequence in the Deer Lodge basin. The sequence contains several beds of possible host rocks that are greater than $20 \mathrm{ft}$ thick. Favorable chemical indicators are present, and potential host rocks and adjacent fine-grained beds contain carbonaceous material. The rating is based on data collected from exposures of a small part of the total section. Most exposures are on the west side of the basin and consist of Miocene and Pliocene rocks.

Sedimentary rocks of early 0ligocene age have favorable lithologic and chemical characteristics but are poorly exposed; they may underlie a large part of this basin, however. These rocks are favorable in many other southwestern Montana basins where they are better exposed; therefore, this basin may be more favorable than the surface data indicate. The favorability of the basin is further enhanced by its proximity to the Boulder batholith.

\section{FLINT CREEK AND GOLD CREEK BASINS}

Data were obtained from surface studies of 11 localities (P1. 2), analyses of 9 rock samples from these localities (App. A), logs of 3 water wells (P1. 2), 6 measured sections described in the 1iterature (App. B), and the cited references.

Tertiary sedimentary rocks that underlie the Flint Creek and Gold Creek basins range from 01igocene to P1iocene in age. Basal Tertiary rocks constitute a pre-Miocene (probably Oligocene) paleoregolith which unconformably overlies older rocks and which ranges in thickness from 0 to $150 \mathrm{ft}$ (Gwinn, 1960, Table 1). These basal strata are overlain by the Cabbage Patch Formation of late 0ligocene to early Miocene age (Gwinn, 1960, p. 105), which has a maximum thickness of 2,200 ft (Rasmussen, 1969, p. 29). The Flint Creek Formation (Gwinn, 1960, p. 105) of late Miocene age (Rasmussen, 1969, p. 84) rests unconformably upon Cabbage Patch rocks and ranges from 0 to $600 \mathrm{ft}$ in thickness (Gwinn, 1960, Table 1). Rocks of Pliocene age lie disconformably on all older rocks and include the $0-$ to 250-ft-thick Barnes Creek Gravel (Rasmussen, 1960, Table 1) and the Bert Creek Formation. The Bert Creek Formation is mostly grave1, has a maximum known thickness of $46 \mathrm{ft}$, and is of early Pliocene age (Rasmussen, 1969, p. 86-91). Because the Cabbage Patch Formation represents most of the total Tertiary section exposed in these basins, the discussion of favorability mostly pertains to this formation. 


\section{Favorability Characteristics}

The maximum stratigraphic thickness of the Tertiary section is more than 3,000 ft, but the thickness of the rocks at any single place in these basins is not known. Sandstone makes up from 4 to 8 percent of the Cabbage Patch Formation (Rasmussen, 1969, p. 28) but is less in the overlying Flint Creek Formation (Gwinn, 1961). Sandstone percent, calculated from lithologic logs of three water wells, ranges from 0 to 27 percent and averages about 7 percent.

Possible host rocks range from medium-grained sandstone to conglomerate. They are arkosic to feldspathic, poorly to moderately sorted, and iron stained in some places. The sandstones generally are impermeable and form beds that average less than $10 \mathrm{ft}$ in thickness, although several sandstone beds greater than $25 \mathrm{ft}$ in thickness have been reported (Rasmussen, 1969, p. 39).

Mudstones, claystones, and siltstones, which separate the potential host rocks, are predominantly composed of volcanic ash. In places these strata contain minor amounts of carbonaceous woody material and several very thin coal beds (Rasmussen, 1969, p. 54).

Detritus for the Cabbage Patch Formation came from the Boulder batholith (Rasmussen, 1969, p. 75-77), which also may have been a source of sediments and possibly uranium for older Tertiary sedimentary rocks that underlie parts of the basins.

The Bert Creek and Barnes Creek gravels (locs. 157, 110) are poorly sorted and the Bert Creek gravel is feldspathic. The gravels are unconsolidated and have few characteristics favorable for uranium deposits. The oldest Tertiary sediments in this area are treated as undifferentiated Eocene and Oligocene sedimentary rocks in this report (P1. 1). They are composed of red pebbly clay and rhyolitic welded tuff that lie between the Cabbage Patch Formation and Cretaceous strata (Gwinn, 1961).

The Tertiary sedimentary sequence in the Flint Creek and Gold Creek basins is bounded and divided by unconformities (Rasmussen, 1969, p. 20, $21,23)$. In addition, the sequence is cut by several faults, along which uraniferous fluids may have had access to the Tertiary strata.

The mean equivalent uranium content ( $3.1 \mathrm{ppm}$ ) of samples from the Flint Creek and Gold Creek basins is slightly below that of the western basins sample group (Fig. 3). None of the samples have anomalous equivalent uranium contents (Fig. 8).

\section{Conclusions}

Tertiary sedimentary rocks of the Flint Creek and Gold Creek basins have poor favorability for uranium deposits. The sandstone percent of these rocks is low; potential host strata generally are thin; none of the samples contain anomalous equivalent uranium values; no uranium occurrences 
or radioactivity anomalies are known; and potential host rocks contain no known carbonaceous material. Although the Boulder batholith was the source of detritus for lower Miocene sediments, they are not enriched in uranium. older Tertiary sedimentary rocks, which are favorable in other basins, are poorly exposed in these basins but may be widespread in the subsurface.

Sandstones and conglomerates of the Cabbage Patch Formation were the only potentially favorable units exposed, and represent the majority of the units sampled.

\section{BIG HOLE RIVER AND BULL CREEK BASINS}

Data were obtained from surface studies of 11 localities (P1. 2), analyses of 24 rock samples from these localities (App. A), logs of 3 water wells and 1 uranium exploration drill hole (P1. 2), and the cited references. Sedimentary rocks in these basins are of undifferentiated Tertiary age.

\section{Favorability Characteristics}

Tertiary sedimentary rocks are at least $1,290 \mathrm{ft}$ thick in the east-central part of the Big Hole River basin (uranium exploration drill hole 14, App. I). The basin is large and probably contains a much thicker sequence of Tertiary sedimentary rocks. Detritus in these rocks probably was derived in part from granitic rocks in the Idaho batholith and Pioneer Mountains.

It was not possible to estimate the proportion of sandstone and conglomerate for Tertiary sedimentary rocks in the Big Hole River and Bull Creek basins because too little of the Tertiary section is exposed. Sand percentages of the limited surface exposures appear to be high, but percentages indicated in two of the three water wells conflict with outcrop data. The sandstone and conglomerate content of the rocks penetrated by the wells is 2 percent in wel1 36, 4 percent in well 32, and 99 percent in wel1 31 .

Potential host rocks range from medium-grained sandstone to comglomerate. They are poorly sorted, feldspathic or arkosic, and iron stained. Some of the beds penetrated by water well 36 are composed of granitic sand. Beds range from $2 \mathrm{ft}$ to $50 \mathrm{ft}$ in thickness, but most are less than $20 \mathrm{ft}$ thick. Outcrops of potential host rocks are well cemented and impermeable. Some of the conglomerate in water well 31 is cemented with lime and presumed to be impermeable. Trace amounts of carbonaceous material are in fine-grained beds adjacent to potential host rocks at localities 118 and 119 and are in potential host rocks at locality 119. Volcanic ash is interbedded with sandstones throughout much of the basin (Perry, 1934, p. 9).

No uranium occurrences or radioactivity anomalies were identified in this investigation; but the periodical Nuclear Canada reported in March 1971 that encouraging "roll front" uranium mineralization had been found on "both Montana prospects" of Denison Mines (Law, 1971, p. 8). This firm conducted drilling in the Big Hole basin in June 1970; and although no anomalies were noted on a gamma-ray $\log$ released by Denison (drill hole 14, Table I-1), the relatively close time relationship between the news release and the completion date of this 
drill hole may indicate that the Big Hole basin is more favorable for uranium than can be demonstrated by surface geology.

The mean equivalent uranium content $(4.5 \mathrm{ppm})$ for rock samples from the Big Hole and Bull Creek basins is slightly higher than the mean content for samples in the western basins group (Fig. 3). Equivalent uranium content for samples from locality 119 is anomalously high when compared with the mean concentrations in either (1) samples from the Big Hole and Bull Creek basins or (2) all samples from the western basins (Fig. 3). Samples $119-5$ and 119-8 have anomalous uranium, and samples 119-3 and 119-6 contain higher-than-average amounts of uranium (Fig. 9).

Dips in the Tertiary strata are mostly low. The Tertiary section is cut by normal and strike-slip faults on the east side of the Big Hole basin (Ruppe1, 1964, p. C14, C15).

\section{Conclusions}

Tertiary sedimentary rocks of the Big Hole River and Bull Creek basins have moderate favorability for uranium deposits because (1) the thick sedimentary sequence contains several beds of potential host rocks that are greater than $20 \mathrm{ft}$ thick; (2) samples from one locality in the Bull Creek basin contain anomalously high equivalent uranium relative to equivalent thorium; (3) the potential host rocks and the adjacent fine-grained strata contain carbonaceous material; and (4) the Big Hole basin may be the location of roll-front uranium mineralization reported in the literature.

Because of the paucity of outcrops and subsurface information, only a small part of the total Tertiary section was studied. More subsurface information is needed for an accurate and complete determination of favorability for uranium in these rocks.

\section{DEEP CREEK BASIN}

Data were obtained from surface studies of five localities (P1. 2), analyses of six rock samples from these localities (App. A), and the cited references. Sedimentary rocks studied in the Deep Creek basin are of undifferentiated Tertiary age.

Potential host rocks range from medium-grained sandstone to conglomerate and are arkosic, poorly sorted, moderately permeable, and iron stained. They contain minor amounts of carbonaceous material and are separated by tuffaceous fine-grained rocks that also are partly carbonaceous. The sandstone and conglomerate beds are less than $10 \mathrm{ft}$ thick, except for a 16-ft bed described at locality 149. The equivalent uranium contents of samples 148-2 and 149-1 (Fig. 9) are above average, but are not anomalously high.

The presumed sources of detrital material for the basin are nearby plutonic rocks and tuffs of Tertiary age. No uranium occurrences are known to be associated with these rocks. 


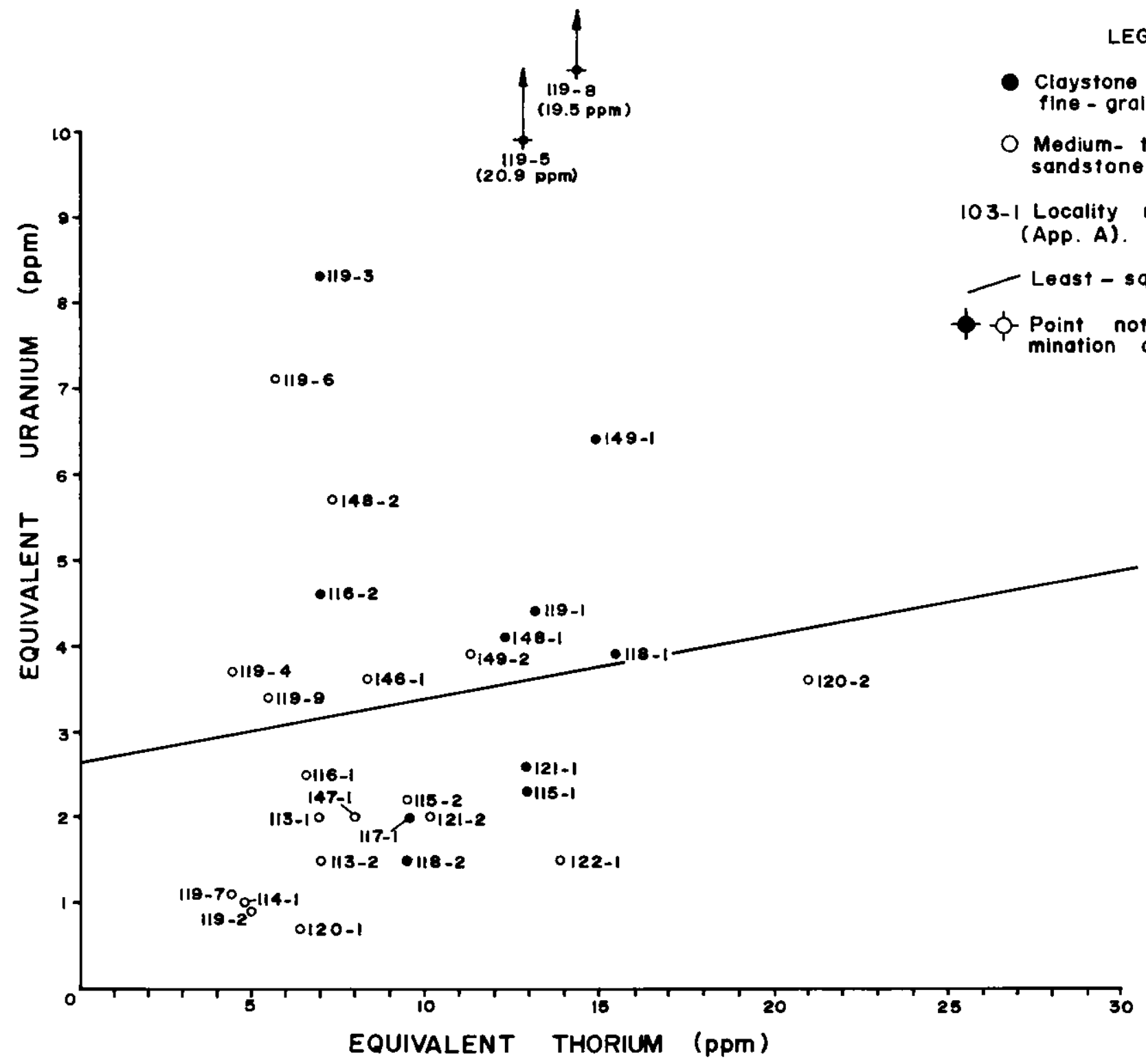

Figure 9. Plot of equivalent uranium versus equivalent thorium for samples from the Big Hole, Bull Creek, and Deep Creek basins. 
Stratigraphic and chemical characteristics of Tertiary rocks in the Deep Creek basin are unfavorable, and lithologic characteristics are only moderately favorable. Data were derived from exposures of only a small part of the Tertiary section and are insufficient to provide a meaningful favorability rating.

WISE RIVER, BLACKFOOT, DOUGLAS CREEK, AVON, ROCK CREEK, AND PHILIPSBURG BASINS

Data for evaluation of the Wise River, Blackfoot, Douglas Creek, Avon, Rock Creek, and Philipsburg basins were obtained from surface studies of 20 localities (P1. 2), analyses of 15 rock samples from these localities (App. A), logs of 4 water wells (P1. 2), and the cited references. The sedimentary rocks studied in these basins range from Eocene to Pliocene in age, but they are not subdivided by age for the following discussion.

\section{Favorability Characteristics}

The Tertiary section in the basins is poorly exposed. Its maximum thickness is unknown, and its sandstone content appears to be low. Potential host rocks are few and range from medium-grained sandstone to conglomerate that generally are poorly sorted. Sandstones and conglomerates are feldspathic in the Wise River basin, arkosic in the Blackfoot basin, and iron stained in the Blackfoot and Rock Creek basins. Both the potential host rocks and the fine-grained strata in the Blackfoot and Avon basins contain carbonaceous material. In the Douglas Creek basin only claystones and siltstones are carbonaceous. Tuffaceous material was observed in two basins; and faults, which may cut Tertiary rocks, have been reported for three basins (Pardee, 1950, p. 388-389, 396-397, P1. 1; Bierwagen, 1964, P1. 1). The Avon basin is the only basin from this group that is sufficiently close to uraniferous rocks of the Boulder batholith to have received drainage and, possibly, detritus from them. However, no uranium occurrences have been reported in these basins, and favorable chemical indicators are lacking in the rocks that were sampled (Fig. 10).

\section{Conclusions}

Lack of data precludes assigning a meaningful favorability rating to the Tertiary rocks of this basin group. The Avon basin may be the most favorable of these basins because it is the closest to the Boulder batholith. Much additional subsurface information is needed to adequately evaluate the Tertiary rocks of these basins.

\section{BITTERROOT BASIN}

Data for the Bitterroot basin were obtained from surface studies of 13 localities (P1. 2), analyses of 16 rock samples from these localities (App. A), logs of 2 water wells (P1.2), 2 measured sections described in 


\section{LEGEND}

- Claystone, siltstone, or fine - grained sandstone

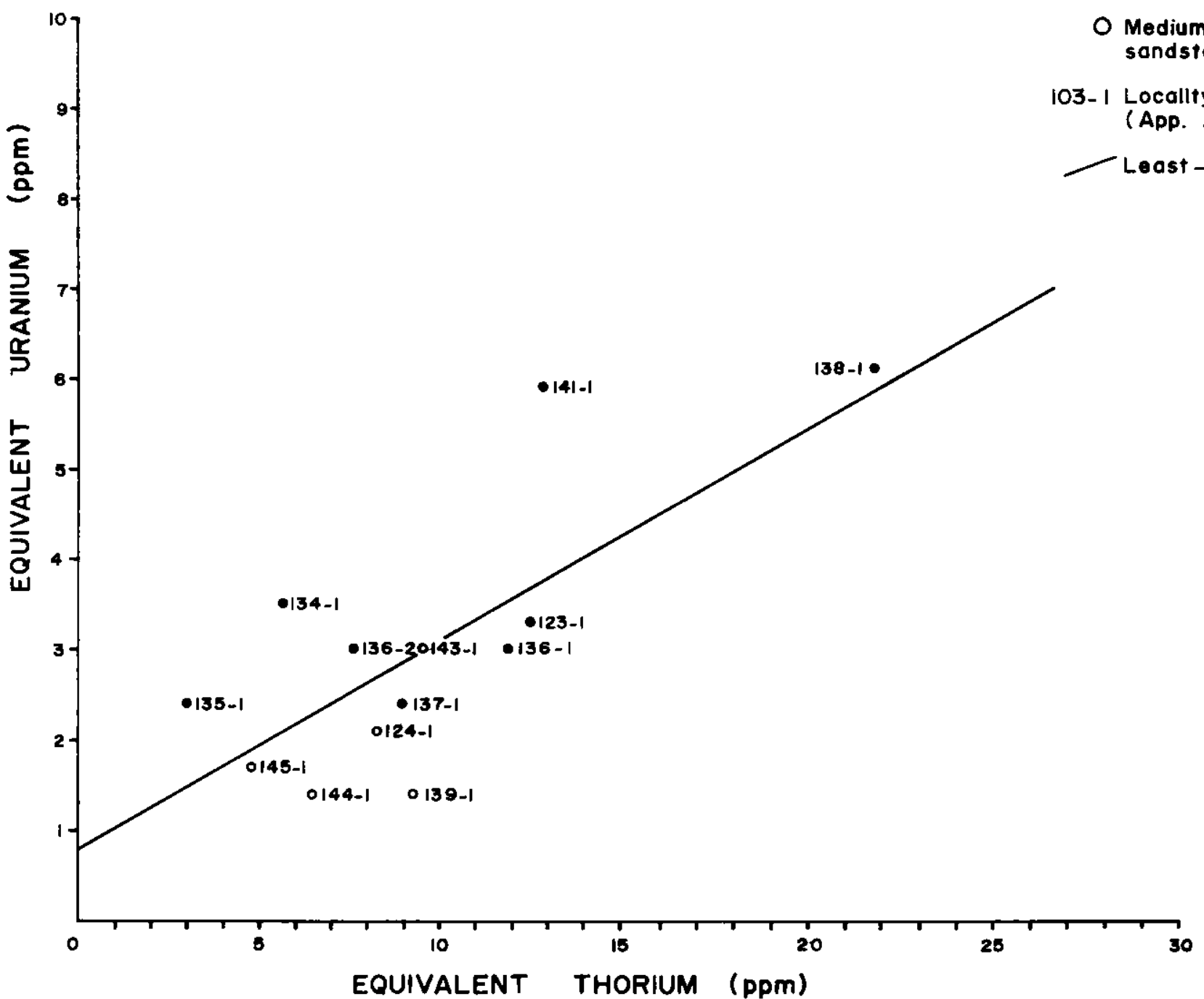

Figure 10. Plot of equivalent uranium versus equivalent thorium for samples from the Wise River, Blackfoot, Douglas Creek, Avon, and Rock Creek basins. 
the literature (App. B), and the cited references. The sedimentary rocks range from Miocene (or late 0ligocene) to early Pliocene in age (McMurtrey and others, 1972, p. 20, 21).

\section{Favorability Characteristics}

The Bitterroot basin is large and contains a relatively thick sequence of Tertiary sedimentary rocks. Although unexposed, sedimentary rocks of the favorable lower Tertiary sequence may be present at depth in the basin. The Idaho batholith was probably an important source of sediment and may have been a source of uranium for the basin.

Cenozoic sedimentary rocks along the axis of the basin have an average thickness of about 3,000 ft, and have a maximum thickness of 4,000 ft just north of Hamilton (Lankston, 1975, P1s. 1, 3a-3f). Less than $500 \mathrm{ft}$ of Quaternary alluvium overlies Tertiary sedimentary rocks (Lankston, 1975, p. 3). A petroleum test well in the southern part of the basin penetrated at least 1,410 ft of Tertiary sedimentary rocks (McMurtrey and others, 1972, p. 15). Gravity data indicate that the basin-fill rocks thin rapidly toward the margins of the basin. At the northwest margin of the basin, water well 28 (P1. 2) penetrated only $175 \mathrm{ft}$ of Cenozoic sediments before entering granitic basement.

Sandstone and conglomerate make up about 74 percent of the $405 \mathrm{ft}$ of Tertiary rocks penetrated by water well 17 . Sandstone percent of surface localities also is high. The Tertiary sequence contains abundant tuffaceous material, which might be a source of uranium.

Potential host rocks range from medium-grained sandstone to conglomerate and are arkosic or feldspathic, poorly sorted, permeable, and iron stained. Outcrops indicate that most potential host rock beds are less than $10 \mathrm{ft}$ thick, although a few are as much as $30 \mathrm{ft}$ thick. A sandstone interval $210 \mathrm{ft}$ thick was penetrated by water well 17 .

Minor amounts of carbonaceous material are in fine-grained tuffaceous rocks both above and below potential host rocks. McMurtrey and others (1972, p. 21) reported semi-indurated plant beds of Miocene or late 0ligocene age on the southwest side of the valley.

The mean equivalent uranium content for samples from the Bitterroot basin (Table 3) is close to the mean for samples of the western basins (Fig. 3). Sample 125-2, of carbonaceous claystone, contains an anomalously high amount of equivalent uranium (Fig. 11) and anomalous concentrations of $\mathrm{Cr}$ and Li (App. E).

Structural development of the Bitterroot basin may be interpreted as a result of either down-faulting (McMurtrey and others, 1972, p. 27-31) or gravity-sliding (Lankston, 1975, p. 3, 47; Hyndman and others, 1975, Fig. 2). High-angle faulting would improve the favorability of the rocks in this basin. 


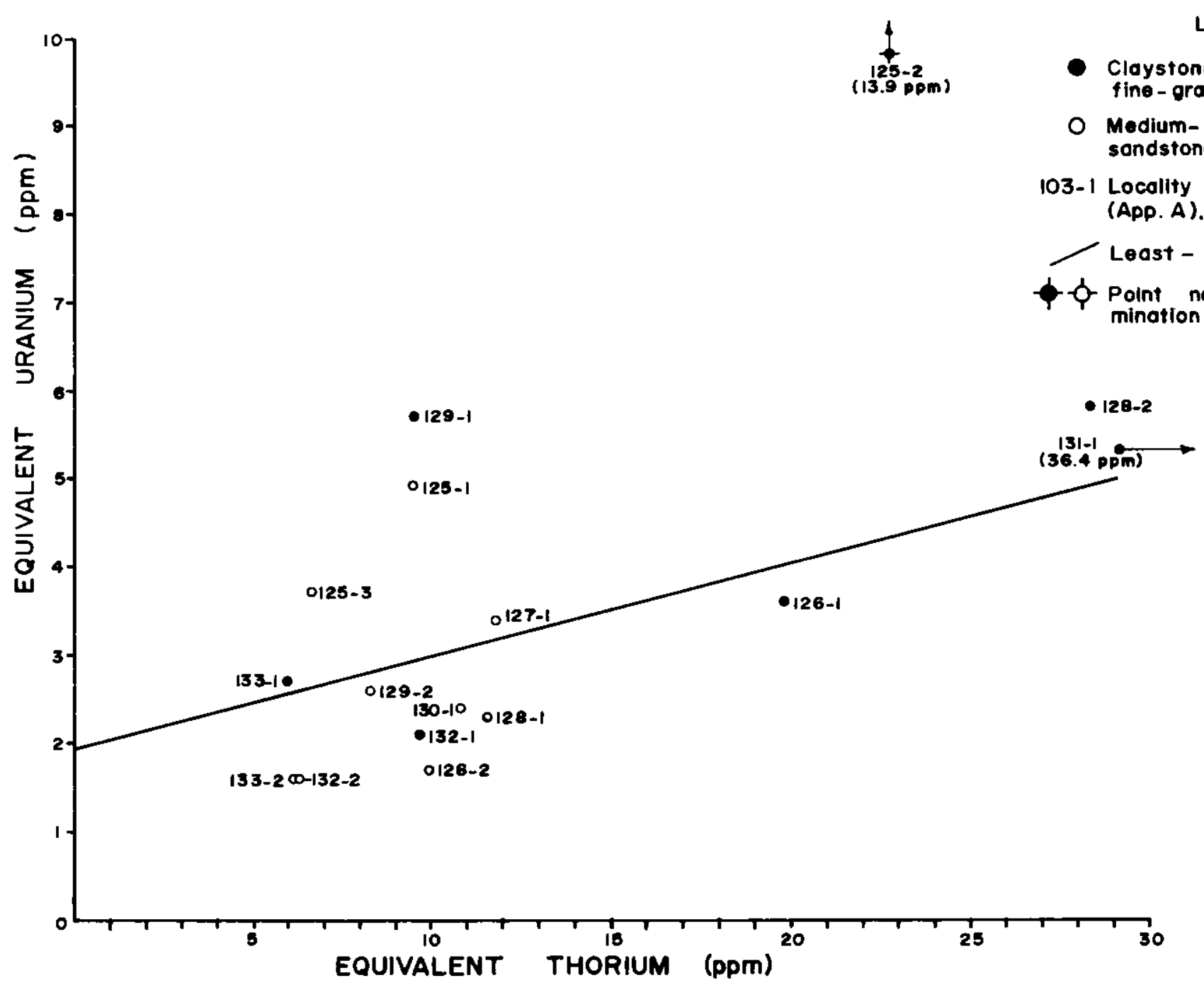

Figure 11. Plot of equivalent uranium versus equivalent thorium for samples from the Bitterroot basin. 


\section{Conclusions}

On the basis of 1imited stratigraphic, lithologic, chemical, structural, and geophysical data and other pertinent characteristics, the Tertiary sedimentary rocks in the Bitterroot basin have poor favorability for uranium deposits. Although a favorable sedimentary rock sequence is present, the strata lack uranium occurrences and radioactivity anomalies; and potential host rocks contain no known reductants or permeability barriers.

These conclusions are based on surface and subsurface data gathered mostly from the eastern side of the basin (P1. 2). However, these data may not be representative of the total Tertiary section because all the strata exposed on the eastern side are of early Pliocene age, whereas rocks as old as Miocene age (perhaps late oligocene) have been reported from another part of the basin (McMurtrey and others, 1972, p. 21). 
Alden, W. C., 1953, Physiography and glacial geology of western Montana and adjacent areas: U.S. Geo1. Survey Prof. Paper 231, 200 p.

Alexander, R. G., Jr., 1955, The Geology of the Whiteha11 area, Montana: Yellowstone-Bighorn Research Assoc., Inc., Proj. Contr. 195, 111 p.

Andretta, D. B., and Alsup, S. A., 1960, Geology and Cenozoic history of the Norris-E1k Creek area, southwest Montana, in Billings Geol. Soc. 1lth Ann. Field Conf., West Yellowstone-Earthquake area, 1960: p. 185-190.

Becraft, G. E., 1958, Uranium in carbonaceous rocks in the Townsend and Helena Valleys, Montana: U.S. Geol. Survey Bul1. 1046-G, p. 149-164.

Berry, G. W., 1943, Stratigraphy and structure at Three Forks, Montana: Geo1. Soc. America Bu11., v. 54, p. 1-30.

Bierwagen, E. E., 1964, Geology of the Black Mountain area, Lewis, Clark, and Powell Counties, Montana [Ph.D. thesis]: Princeton, New Jersey, Princeton Univ., 120 p.

Birkholz, D. 0., 1967, Geology of the Camas Creek area, Meagher County, Montana [M.S. thesis]: Butte, Montana Co11. Minera1 Sci. and Technology, $68 \mathrm{p}$.

Brenner, R. L., 1964, Geology of Lubrecht experimental forest, Missoula County, Montana [M.S. thesis]: Missoula, Univ. Montana, $63 \mathrm{p}$.

Burfeind, W. J., 1967, A gravity investigation of the Tobacco Root Mountains, Jefferson Basin, Boulder Batholith and adjacent areas of southwestern Montana [Ph.D. thesis]: Bloomington, Indiana Univ., 90 p.

Csejtey, Be'la, Jr., 1963, Geology of the southeast flank of the Flint Creek Range, western Montana [Ph.D. thesis]: Princeton, New Jersey, Princeton Univ., 75 p.

Dahl, G. G., Jr., 1971, General geology of the area drained by the north fork of the Smith River, Meagher County, Montana [M.S. thesis]: Butte, Montana Col1. Mineral Sci. and Technology, $58 \mathrm{p}$.

Davis, W. E., Kinoshita, W. T., and Smedes, H. W., 1963, Bouguer gravity, aeromagnetic, and generalized geologic map of East Helena and Canyon Ferry quadrangles and part of the Diamond City quadrangle, Lewis and Clark, Broadwater, and Jefferson Counties, Montana: U.S. Geol. Survey Geophys. Inv. Map GP-444, 6 p., 2 sheets.

Davis, W. E., Kinoshita, W. T., and Robinson, G. D., 1965a, Bouguer gravity, aeromagnetic, and generalized geologic map of the eastern part of the Three Forks Basin, Broadwater, Madison, and Gallatin Counties, Montana: U.S. Geol. Survey Geophys. Inv. Map GP-498, 5 p., 2 sheets. 


\section{REFERENCES CITED (continued)}

Davis, W. E., Kinoshita, W. T., and Robinson, G. D., 1965b, Bouguer gravity, aeromagnetic, and generalized geologic map of the western part of the Three Forks Basin, Jefferson, Broadwater, Madison, and Gallatin Counties, Montana: U.S. Geol. Survey Geophys. Inv. Map GP-497, 5 p., 2 sheets.

Dorr, J. A., Jr., and Wheeler, W. H., 1964, Cenozoic paleontology, stratigraphy, and reconnaissance geology of the Upper Ruby River basin, southwestern Montana: Michigan Univ. Mus. Paleontology Contr., v. 13, no. 12, p. 297-339.

Douglass, Ear1, 1902, Fossil Mammalia of the White River beds of Montana: Am. Philos. Soc. Trans., v. 20, p. 237-279.

Egbert, R. L., 1967, Geologic map of the Madison Valley-Hebgen Lake, southwestern Montana [field conference map], in Montana Geol. Soc. Guidebook 18th Ann. Field Conf., Centennia1 Basin of southwest Montana, 1967: scale $1: 226,286$.

Feichtinger, S. H., 1970, Geology of a portion of the Norris quadrangle with emphasis on Tertiary sediments, Madison and Gallatin Counties, Montana [M.S. thesis]: Bozeman, Montana State Univ., 85 p.

Fraser, G. D., and Waldrop, H. A., 1972, Geologic map of the Wise River quadrangle, Silver Bow and Beaverhead Counties, Montana: U.S. Geol. Survey Geol. Quad. Map GQ-988.

Freeman, V. I., Ruppe1, E. T., and Klepper, M. R., 1958, Geology of part of the Townsend Valley, Broadwater and Jefferson Counties, Montana: U.S. Geo1. Survey Bu11. 1042-N, p. 481-556.

Glancy, P. A., 1964, Cenozoic geology of the southeastern part of the Gallatin Valley, Montana [M.S. thesis]: Bozeman, Montana State Univ., 66 p.

Groff, S. L., 1965, Reconnaissance ground water and geological studies, western Meagher County, Montana: Montana Bur. Mines and Geology Spec. Pub. 35, 23 p.

Grutt, E. W., Jr., 1972, Prospecting criteria for sandstone-type uranium deposits, in Bowie, S.H.U., Davis, Michael, and Ostle, Dennis, eds., Uranium prospecting handbook: London, Inst. Mining and Metallurgy, p. $47-75$.

Gwinn, V. E., 1960, Cretaceous and Tertiary stratigraphy and structural geology of the Drummond area, Montana [Ph.D. thesis]: Princeton, New Jersey, Princeton Univ., $127 \mathrm{p}$.

1961, Geology of the Drummond area, central-western Montana: Montana Bur. Mines and Geology Spec. Pub. 21 (Geo1. Map 4), scale 1:62,118. 
Hackett, O. M., Visher, F. N., McMurtrey, R. G., and Steinhilber, W. L., 1960, Geology and ground-water resources of the Gallatin Valley, Gallatin County, Montana, with a section on Surface-water resources by Frank Stermitz and F. C. Boner, and a section on Chemical quality of the water by R. A. Krieger: U.S. Geol. Survey Water-Supply Paper 1482, 282 p.

Hadley, J. B., 1969a, Geologic map of the Cameron quadrangle, Madison County, Montana: U.S. Geo1. Survey Geol. Quad. Map GQ-813.

1969b, Geologic map of the Varney quadrangle, Madison County, Montana: U.S. Geol. Survey Geol. Quad. Map GQ-814.

Hibbard, C. W., and Keenmon, K. A., 1950, New evidence of the lower Miocene age of the Blacktail Deer Creek Formation in Montana: Michigan Univ. Mus. Paleontology Contr., v. 8, no. 7, p. 193-204.

Hoffman, D. S., 1972, Tertiary stratigraphy, vertebrate paleontology, and paleoecology of a portion of the lower Beaverhead River basin, Madison and Beaverhead Counties [Ph.D. thesis]: Missoula, Montana State Univ., $174 \mathrm{p}$.

Hough, Jean, 1955, An upper Eocene fauna from the Sage Creek area, Beaverhead County, Montana: Jour. Paleontology, v. 29, no. 1, p. 22-36.

Hruska, D. C., 1967, Geology of Dry Range area, Meagher County, Montana [M.S. thesis]: Butte, Montana Col1. Mineral Sci. and Technology, $89 \mathrm{p}$.

Hyndman, D. W., Talbot, J. L., and Chase, R. B., 1975, Boulder batholith: A result of emplacement of a block detached from the Idaho batholith infrastructure?: Geology, v. 3, p. 401-404.

Jarrard, L. D., 1955, Hi Boy Claims 1-2-3-4: U.S. Atomic Energy Comm. Prelim. Reconn. Rept. B-B-195, Open-File Rept.

Jarrard, L. D., and VanAlstine, C. L., 1954, Unnamed property near Alder, Montana: U.S. Atomic Energy Comm. Prelim. Reconn. Rept. B-B-186, Open-File Rept.

Jerome, N. H., 1968, Geology between Miller and Eightmile Creeks, Northern Sapphire Range, western Montana [M.S. thesis]: Missoula, Univ. Montana, $48 \mathrm{p}$.

Kay, J. L., and Fields, R. W., 1958, Second day of Eighth Field Conference (Pipestone, Anceney, Virginia City, and return), in Fields, R. W., ed., Guidebook of the 8th Field Conference of the Society of Vertebrate Paleontology: Missoula, Montana State Univ. Press, p. 13-15.

Kinoshita, W. T., Davis, W. E., Smedes, H. W., and Nelson, W. H., 1964, Bouguer gravity, aeromagnetic, and generalized geologic map of Townsend and Duck Creek Pass quadrangles, Broadwater County, Montana: U.S. Geol. Survey Geophys. Inv. Map GP $-439,6$ p., 2 sheets. 


\section{REFERENCES CITED (continued)}

Kinoshita, W. T., Davis, W. E., and Robinson, G. D., 1965, Aeromagnetic, Bouguer gravity, and generalized geologic map of Toston and Radersburg quadrangles and part of the Devils Fence quadrangle, Gallatin, Broadwater, and Jefferson Counties, Montana: U.S. Geo1. Survey Geophys. Inv. Map GP -496 , 6 p., 2 sheets.

Klemme, H.D., 1949, Geology of the Sixteen Mile Creek Area, Montana [Ph.D. thesis]: Princeton, New Jersey, Princeton Univ., 206 p.

Klepper, M. R., Ruppe1, E. T., and Weeks, R. A., 1957, Geology of the southern Elkhorn Mountains, Jefferson and Broadwater Counties, Montana: U.S. Geol. Survey Prof. Paper 292, 82 p. [1958].

Klepper, M. R., Ruppe1, E. T., Freeman, V. L., and Weeks, R. A., 1971, Geology and mineral deposits, east flank of the Elkhorn Mountains, Broadwater County, Montana: U.S. Geol. Survey Prof. Paper 665, 66 p.

Koerner, H. E., 1939, The geology and vertebrate paleontology of the Fort Logan and Deep River Formations of Montana [Ph.D. thesis]: New Haven, Connecticut, Yale Univ., 141 p.

Konizeski, R. L., 1961, Paleoecology of an ear1y 01igocene biota from Douglas Creek basin, Montana: Geol. Soc. America Bull., v. 72, p. 1633-1642.

Konizeski, R. L., McMurtrey, R. G., and Brietkrietz, Alex, 1962, Preliminary report on the geology and ground-water resources of the southern part of the Deer Lodge Valley, Montana: Montana Bur. Mines and Geology Bu11. 31,24 p. 1968, Geology and ground-water resources of the Deer Lodge Valley, Montana, with a section on Gravimetric survey by E. A. Cremer III: U.S. Geol. Survey Water-Supply Paper 1862, 55 p.

Kuenzi, W. D., 1966, Tertiary stratigraphy in the Jefferson River basin, Montana, [Ph.D. thesis]: Missoula, Univ. Montana, 293 p.

Kuenzi, W. D., and Fields, R. W., 1971, Tertiary stratigraphy, structure, and geologic history, Jefferson basin, Montana: Geol. Soc. America Bull., v. 82, p. $3373-3394$.

Lankston, R. W., 1975, A geophysical investigation in the Bitterroot Valley, western Montana [Ph.D. thesis]: Missoula, Univ. Montana., $112 \mathrm{p}$.

Law, C., ed., 1971, Denison Mines' exploration program smaller but wider spread: Nuclear Canada, v. 10, no. 3, p. 7-9.

Lorenz, H. W., and McMurtrey, R. G., 1956, Geology and occurrence of ground water in the Townsend Valley, Montana, with a section on Chemical quality of the ground water by H. A. Swenson: U.S. Geol. Survey Water-Supply Paper 1360-C, p. 171-290. 


\section{REFERENCES CITED (continued)}

Lorenz, H. W., and Swenson, F. A., 1951, Geology and ground-water resources of the Helena Valley, Montana, with a section on the Chemical quality of the water by H. A. Swenson: U.S. Geol. Survey Circ. 83, 68 p.

Lowel1, W. R., 1952, Preliminary geologic map of the SW/ Willis quadrangle, Beaverhead County, Montana: U.S. Geol. Survey Open-File Rept., scale $1: 31,680$.

Lowe11, W. R., and Klepper, M. R., 1953, Beaverhead Formation, a Larimide deposit in Beaverhead County, Montana: Geol. Soc. America Bull., v. 64, p. $235-243$.

Malan, R. C., and Sterling, D. A., 1970, Geologic study of uranium resources in Precambrian rocks of the western United States, distribution of uranium and thorium in the Precambrian of the west-central and northwest United States: U.S. Atomic Energy Comm., AEC-RD-11, Open-File Rept., 64 p.

Marjaniemi, D. K., and Robins, J. W., 1975a, Uranium favorability of Tertiary sedimentary rocks of the lower Spokane River Valley and of nor thern Spokane County, Washington: U.S. Energy Research and Deve1. Adm., GJBX-1(76), Open-File Rept., 48 p.

$1975 \mathrm{~b}$, Uranium favorability of Tertiary sedimentary rocks of the Pend Oreille River Valley, Washington: U.S. Energy Research and Devel. Adm., GJBX-3(76), Open-File Rept., 62 p.

McClernan, H. G., 1969, Geology of Sheep Creek area, Meagher County, Montana [M.S. thesis]: Butte, Montana Co11. Mineral Sci. and Technology, $51 \mathrm{p}$.

McGrew, L. W., 1974a, Geologic map of the Black Butte Mountain quadrangle, Meagher County, Montana: U.S. Geol. Survey Open-File Rept. 74-106, scale 1:24,000.

1974b, Geologic map of the Ringling quadrangle, Meagher County, Montana: U.S. Geol. Survey Open-File Rept. 74-107, scale 1:24,000.

$1974 \mathrm{c}$, Geologic map of the Sixteen quadrangle, Gallatin and Meagher Counties, Montana: U.S. Geol. Survey Open-File Rept. 74-108, scale $1: 24,000$.

1974d, Geologic map of the Sixteen NE quadrangle, Gallatin, Meagher, and Park Counties, Montana: U.S. Geol. Survey Open-File Rept. 74-109, scale $1: 24,000$.

McMannis, W. J., 1955, Geology of the Bridger Range, Montana: Geol. Soc. America Bu11., v. 66, p. 1385-1430.

MeMurtrey, R. G., Konizeski, R. L., Johnson, M. V., and Bartells, J. H., 1972, Geology and water resources of the Bitterroot Valley, southwestern Montana, with a section on Chemical quality of water by H. A. Swenson: U.S. Geol. Survey Water-Supply Paper 1889, 80 p. 
REFERENCES CITED (continued)

Mertic, J. B., Jr., Fischer, R. P., and Hobbs, S. W., 1951, Geology of the Canyon Ferry quadrangle, Montana: U.S. Geo1. Survey Bul1. 972, 97 p. [1952].

M'Gonigle, J. W., 1965, Structure of the Maiden Peak area, Beaverhead Range, Montana-Idaho [Ph.D. thesis]: University Park, Pennsylvania State Univ., $146 \mathrm{p}$.

Mifflin, M. D., 1963, Geology of a part of the southern margin of Gallatin Valley, southwest Montana [M.S. thesis]: Bozeman, Montana State Univ., 111 p.

Moen, W. S., and Hetland, D. L., 1953, Harrison property: U.S. Atomic Energy Comm. Prelim. Reconn. Rept. B-B-126, Open-File Rept.

Mutch, T. A., 1961, Geology of the northeast flank of the Flint Creek Range, western Montana: Montana Bur. Mines and Geology Spec. Pub. 22 (Geol. Map 5), scale $1: 63,360$.

Myers, W. B., 1952, Geology and mineral deposits of the northwest quarter Willis quadrangle and adjacent Browns Lake area, Beaverhead County, Montana: U.S. Geol. Survey Open-File Rept.

Nelson, W. H., 1963, Geology of the Duck Creek Pass quadrangle, Montana: U.S. Geol. Survey Bul1. 1121-J, P. J1-J56.

Noel, J. A., 1956, The Geology of the east end of the Anaconda Range and adjacent areas, Montana [Ph.D. thesis]: Bloomington, Indiana Univ., 74 p.

Pardee, J. T., 1925, Geology and ground water resources of Townsend Va1ley, Montana: U.S. Geo1. Survey Water-Supply Paper 539, $61 \mathrm{p}$. 1950, Late Cenozoic block faulting in western Montana: Geol. Soc. America Bul1., v. 61, p. 359-406.

Pardee, J. T., and Schrader, F. C., 1933, Metalliferous deposits of the greater Helena mining region, Montana: U.S. Geo1. Survey Bull. 842, 318 p.

Perry, E. S., 1934, Physiography and ground-water supply in the Big Hole basin, Montana: Montana Bur. Mines and Geology Mem. 12, $18 \mathrm{p}$.

Petkewich, R. M., 1972, Tertiary geology and paleontology of the Beaverhead east area, southwestern Montana [Ph.D. thesis]: Missoula, Univ. Montana, $365 \mathrm{p}$.

Phelps, G. B., 1969, Geology of the Newlan Creek area, Meagher County, Montana [M.S. thesis]: Butte, Montana Coll. Mineral Sc1. and Technology, $56 \mathrm{p}$.

Poulter, C. J., 1956, Geology of the Georgetown thrust area southwest of Philipsburg, Granite and Deer Lodge Counties, Montana: Montana Bur. Mines and Geology Geol. Map 1, scale 1:48,000. 
Pruitt, R. G., 1955a, Moida Claims: U.S. Atomic Energy Comm. Prelim. Reconn. Rept. B-16, Open-File Rept.

1955b, Leland Peterson farm: U.S. Atomic Energy Comm. Prelim. Reconn. Rept. B-27, Open-File Rept.

Rasmussen, D. L., 1969, Late Cenozoic geology of the Cabbage Patch area, Granite and Powell Counties, Montana [M.S. thesis]: Missoula, Univ. Montana, $188 \mathrm{p}$.

Richard, B. H., 1966, Geologic history of the intermontane basins of the Jefferson Island quadrangle, Montana [Ph.D. thesis]: Bloomington, Indiana Univ., $73 \mathrm{p}$.

Robinson, G. D., 1961, Origin and development of the Three Forks Basin, Montana: Geo1. Soc. America Bul1., v. 72, p. 1003-1014.

1963, Geology of the Three Forks quadrangle, Montana, with sections on Petrography of igneous rocks by H. F. Barnett: U.S. Geol. Survey Prof. Paper 370, $143 \mathrm{p}$.

1967, Geologic map of the Toston quadrangle, southwestern Montana: U.S. Geol. Survey Misc. Inv. Map I-486.

Ross, C. P., Andrews, D. A., and Witkind, I. J., comps., 1955, Geologic map of Montana: U.S. Geol. Survey, scale 1:500,000.

Ruppe1, E. T., 1964, Strike-slip faulting and broken basin-ranges in eastcentral Idaho and adjacent Montana: U.S. Geo1. Survey Prof. Paper 501-C, p. C14-C18.

Ryder, R. T., and Scholten, Robert, 1973, Syntectonic conglomerates in southwestern Montana: Their nature, origin, and tectonic significance: Geol. Soc. America Bul1., v. 84, p. 773-796.

Schneider, G. B., 1970, Cenozoic geology of the Madison Bluffs area, Gallatin County, Montana [M.S. thesis]: Bozeman, Montana State Univ., 61 p.

Scholten, Robert, Keenmon, K. A., and Kupsch, W. 0., 1955, Geology of the Lima region, southwestern Montana and adjacent Idaho: Geol. Soc. America Bull., v. 66, p. 345-404.

Scott, J. H., Dodd, P. H., Droullard, R. F., and Mudra, P. J., 1960, Quantitative interpretation of gamma-ray logs: U.S. Atomic Energy Comm., RME-136, Open-File Rept., 27 p.

Shea, T. K., 1947, Geology and mines of the Upper Blackfoot Valley, Montana [B.S. thesis]: Butte, Montana School Mines, $30 \mathrm{p}$.

Smedes, H. W., 1966, Geology and igneous petrology of the northern Elkhorn Mountains, Jefferson and Broadwater Counties, Montana: U.S. Geol. Survey Prof. Paper 510, 116 p. 
Smedes, H. W. 1967, Preliminary geologic map of the Butte South quadrangle, Montana: U.S. Geo1. Survey Open-File Rept., scale 1:24,000.

Tanner, J. J., 1949, Geology of the Castle Mountain area, Montana [Ph.D. thesis]: Princeton, New Jersey, Princeton Univ., 153 p.

Tilling, R. I., and Gottfried, David, 1969, Distribution of thorium, uranium, and potassium in igneous rocks of the Boulder batholith region, Montana, and its bearing on radiogenic heat production and heat flow: U.S. Geol. Survey Prof. Paper 614-E, p. 3-10.

Verral1, Peter, 1955, Geology of the Horseshoe Hills area, Montana [Ph.D. thesis]: Princeton, New Jersey, Princeton Univ. 263 p.

Wanek, A. A., and Barclay, C.S.V., 1966, Geology of the nor thwest quarter of the Anaconda quadrangle, Deer Lodge County, Montana: U.S. Geol. Survey Bu11. 1222-B, 28 p.

Weeks, R. A., 1974, Geologic map of the Bull Mountain area, Jefferson County, Montana: U.S. Geol. Survey Open-File Rept. 74-354, scale 1:48,000.

White, T. E., 1954, Preliminary analysis of the fossil vertebrates of the Canyon Ferry reservoir area, Montana: U.S. Nat1. Mus. Proc., v. 103, no. 3326, p. 395-438.

Wolfe, P. E., 1964, Late Cenozoic uplift and exhumed Rocky Mountains of centra1 western Montana: Geol. Soc. America Bull., v. 75, p. 493-502. 

APPENDIX A

DESCRIPTIONS OF SELECTED ROCK UNITS 


\section{LOCALITY 101. MODESTY CREEK}

NWh $\mathrm{SW}_{\frac{1}{4}} \mathrm{SE}_{\frac{1}{4}} \mathrm{sec} .19$, T. 6 N., R. 10 W.; Deer Lodge County; In roadcut on the south side of road. Mapped as Eocene to Olfgocene Heterogenous deposits by Konizeski and others (1968, P1. 1).

$\frac{\text { Unit }}{2 .}$ Conglomerate; light yellowish gray (weathers to light gray);

Est 1mated thick. (ft) with subrounded pebbles of quartzite $(60 \%)$, quartz $(20 \%)$ and other rock fragments $(20 \%)$, in a matrix of poorly sorted, medium grained, feldspathic, micaceous, sandstone; soft, friable (weathers to medium hard, compact); slope former; iron-stained; tabular uneven; internally massive. Lower contact sharp and irregular. Minor carbonaceous material. Contains a few lenticular beds of clay.

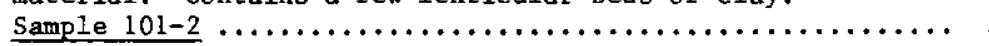

1. Claystone, sandy, micaceous; medium grayish black with brown iron streaks (weathers to mottled medium brown); soft, plastic; slope former; tabular uneven; with internal disturbed irregular, very thin bedding. Lower contact sharp and regular. Minor carbonaceous material. Sample 101-1 $\cdots 1$

Total estimated thickness $\ldots \ldots \ldots \ldots \ldots \ldots \ldots \ldots \ldots \ldots \ldots, 3$

\section{LOCALITY 102. BIELENBERG CANYON}

SWl $\frac{1}{4} \mathrm{NE}_{\frac{1}{4}}^{\frac{1}{4} \mathrm{SE}^{\frac{1}{4}}}$ sec. 7, T. 6 N., R. $10 \mathrm{~W}$.; Powell County; in gully on the north side of road. Mapped as Eocene to Oligocene Heterogeneous deposits by Kontzesk1 and others (1968, P1. 1).

andstone, feldspathic; dark yellowish orange; medium to fine grained, moderately sorted, with subangular grains; soft, loose; slope former; iron-stained; with internal parallel uneven medium bedding. Lower contact sharp and irregular. Sample 102-5 taken at the base .............. 39.7

11. Claystone, sandy, micaceous; medium yellowish brown; soft, plastic; slope former; internally massive. Sample 102-4

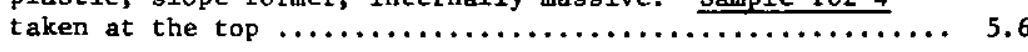

10. Sandstone; streaked light orange gray; medium grained; medium hard, friable; slope former; with internal very thin

lenticular bedding $\ldots \ldots \ldots \ldots \ldots \ldots \ldots \ldots \ldots \ldots \ldots \ldots \ldots \ldots \ldots \ldots, 21.4$

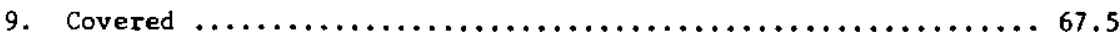

8. Sandstone (60\%); 11ght yellowish gray; fine grained; soft Claystone $(40 \%)$; medium purple brown; soft $\ldots \ldots \ldots \ldots \ldots \ldots \ldots$

7. Conglomerate; soft, friable; subrounded cobble and pebble

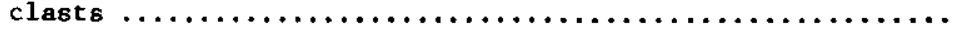

LOCALITY 102. (continued)

$\frac{\text { Unit }}{6 .}$

5. Conglomerate (60\%), micaceous; dark yellowish orange; with subrounded pebbles of quartzite (80\%) and granite (20\%), In a matrix of poorly sorted, coarse grained, feldspathic sandstone; medium hard, friable; slope former; lenticular; internal medium bedded. Lower contact sharp. Minor amount of heavy minerals (magnetite, sphene). Sample 102-2 ...... Sandstone (35\%), feldspathic, micaceous; streaked dark yellowish orange; medium to fine greined, poorly sorted; medium hard, friable; slope former; iron-stained; lenticular bedding. Minor amount of heavy minerals (biotite).

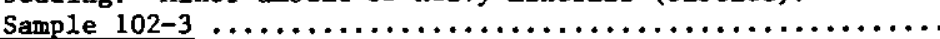
claystone $(5 \%)$ medium grayish brown; soft, plastic; slope former; internal very thin bedding. Trace of carbonaceous

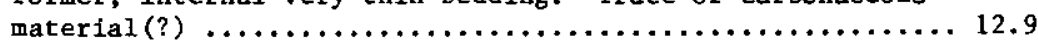

4. C1aystone, silty, micaceous; dark yellowish brown; soft, plast1c; slope former; internally massive. Sample 102-1 ... 5.4

3. Sandstone, feldspathic; medium yellowish gray; medium grained, poorly sorted; soft, loose. Trace of carbonaceous materlal. 2.0

2. Claystone; dark gray; soft, plastic; subordinate amount of

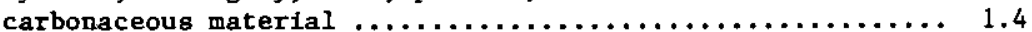

1. Conglomerate; soft, friable; with pebble clasts $\ldots \ldots \ldots \ldots \ldots, 3.4$

Total measured thickness

\section{LOCALITY 103. WILLIAMS RANCH ROAD}

NW/ $\mathrm{SE}_{\frac{1}{4}}^{\frac{1}{4} \mathrm{SE}} \frac{1}{4}$ sec. 8, T. 8 N., R. 9 W.; Powell County; in gravel pit, approximately $1 / 2$ mile south of Williams Ranch. Mapped as Mlocene lacustrine and fluvial deposits by Kontzeski and others (I968, P1. 1).

Estimated

2. Claystone; micaceous; yellowish gray; medium hard, compact lenticular bed. Lower contact sharp and regular. Lens

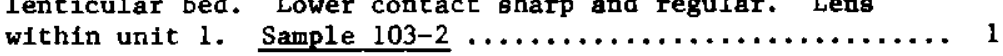

1. Sandstone, conglomeratic, feldspathic; banded gray; coarse to very coarse grained, poorly sorted, with subrounded pebbles of quartz, quartzite, and sandstone; medium hard, friable; slope former; manganese stained; lenticular channel; Internally thin bedded, with trough cross-bedding. Sample 103-1 taken fust above claystone lens (unit 2) $\ldots \ldots .20$

Total estimated thickness $\ldots \ldots \ldots \ldots \ldots \ldots \ldots \ldots \ldots \ldots \ldots, 21$ 


\section{LOCALITY 104. WEST SIDE CANAL PIT}

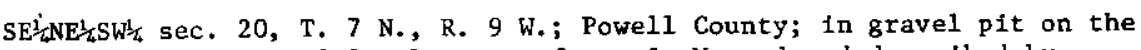
north side of road, 0.1 mile west of canal. Mapped and described by Konizeski and others (1968, p. 17, P1. 1), as P1iocene channel deposits. The section includes a sequence of intertonging conglomerate and sand fluvial channels with tan silty clay lenses. The beds vary in dip from $\left(6.5^{\circ}\right.$ N.W. and $6.5^{\circ}$ N.E.) to approximately horizontal and the strike varies from $\mathrm{N}, 15^{\circ} \mathrm{E}$. to $\mathrm{N}$. $40^{\circ} \mathrm{W}$.

$\frac{\text { Unit }}{5 .}$ Conglomerate; streaked light gray; with rounded pebbles in Conglomerate; streaked light gray; with rounded pebbles
a matrix of poorly sorted, subangular, coarse grained, feldspathic, micaceous, sandstone; soft, frlable; slope former; iron stained; lenticular channel; internally very thin bedded with planar and trough cross-bedding. Lower contact sharp and irregular. Minor amount of heavy minerals. Sample $104-4$ taken at the base ....................6 6

4. Claystone, sandy; dark yellowish gray; soft, loose; slope former; lenticular beds; with internal paralle1 uneven thin bedding. Sample $104-3$ taken at the top $\ldots \ldots \ldots \ldots \ldots 4.6$

3. Sandstone; light brownish gray; coarse gralned, poorly sorted; soft, friable; slope former; lenticular channel; with internal parallel even thin bedding. Lower contact sharp and irregular. .................................... 1.4 Comment: The width of the channel approximately 50 feet.

2. Claystone, sandy; yellowish gray; soft, loose; slope former; manganese stained; lenticular bed; internally masstve. Sand is very fine to coarse grained and poorly sorted.

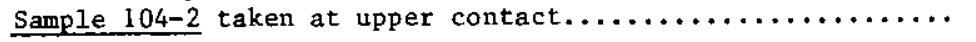

1. Conglomerate, sandy; dark yellowish orange; with rounded pebbles of quartzite $(50 \%)$, granite $(40 \%)$ and quartz; in a matrix of poorly sorted, subangular, coarse grained; feldspathic, micaceous, sands tone; soft, friable; slope former; fron-stained; lenticular channel; internally very thin bedded with planar cross-bedding. Trace of heavy minerals.

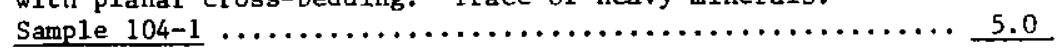

Total measured thickness $\ldots \ldots \ldots \ldots \ldots \ldots \ldots \ldots \ldots \ldots \ldots \ldots, 21.6$

\section{LOCALITY 105. BAILEY GRAVEL PIT}

$\mathrm{NE}_{4}^{\frac{1}{4} \mathrm{NW}} \frac{\mathrm{R}}{4} \mathrm{SE} \frac{1}{4}$ sec. 20, T. 7 N., R. 9 W.; Powell County; north of road, 0.2 miles east of the West Side Canal. Mapped as Alluvium by Konfzeski and others (1968, P1. 1), but is probably PIlocene.
LOCALITY 105. (contInued)

Unit sandstone, feldspathic, micaceous; light olive brown; mediuf thick. (ft) to coarse grained, moderately sorted; soft, friable; slope former; tabular even; internally massive. Minor amount of heavy minerals. Pebbly in places, and contains petriffed wood and bones. Sample 105-1 .............. 20

\section{LOCALITY 106. GI SPRING}

$\mathrm{NW}_{4} \mathrm{SW} / 4 \mathrm{NW}_{4} \mathrm{sec} .21$, T. 8 N., R. 9 W.; Powell County; in gully west of old ranch road, approximately $2 \frac{1}{2}$ miles northwest of Deer Lodge. Mapped as P1focene fluvial deposits by Konizeski and others (1968, P1. 1).

Measured

(1t) former; iron-stalned tabular even; internal parallel even medium bedding. Lower contact gradational. Contains several medium thick clay beds and a few very thin carbonaceous streaks................................. 22

4. Sandstone, feldspathic, conglomeratic; streaked dusky yellow (weathers to green); coarse grained, moderately sorted, with subangular grains; with subangular pebbles of predominantly quartzite; soft, friable; slope former; 1ron-stained tabular even; internally medium bedded with planar cross-bedding. Lower contact sharp and regular. Conglomeratic near base and contains silt rip-up clasts one to two inches in diameter, and several bands of green mineral staining; also contains several thin reddish sandy silt interbeds. Sample 106-4 taken from near the top $\ldots \ldots \ldots \ldots \ldots \ldots \ldots \ldots \ldots \ldots \ldots . \ldots .1$

3. Conglomerate (90\%) banded yellowish gray (weathers to brown) with pebbles of predominantly quartzite in a matrix of very poorly sorted, coarse grained, arkosic sandstone; medium hard, friable; slope former; manganese-stained; lenticular channel; internally thin bedded with planar and trough crossbedding. Lower contact covered. Minor amount of replaced carbonaceous material; minor amount of heavy minerals. Conta1ns many greenish yellow silt rip-up clasts.

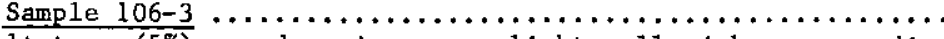
Siltstone (5\%), sandy, micaceous; light yellowish gray; medium hard, compact; slope former; lenticular channel; internally thin bedded with planar cross-bedding. Lower contact sharp and frregular. Stained a yellow green stain and contains a

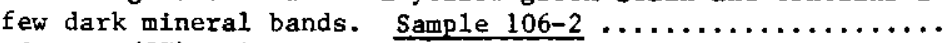

Sandstone (5\%), clayey, conglomeratic; banded 1ight gray; coarse to very coarse grained, poorly sorted; soft; thinly bedded;

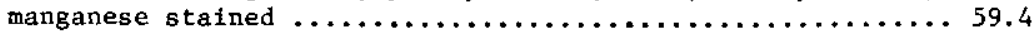

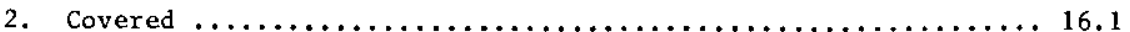


LOCALITY 106. (continued)

Unit

Conglomerate; dark bleckish gray (weathers to black); with subrounded to rounded pebbles of quartzite $(50 \%)$, granite $(25 \%)$, and volcanica (25\%); in a matrix of poorly sorted, very coarse gratoed, feldspathic sandstone; hard; compact; slope former; manganese-stained and cemented (Hollandite, $30 \%$ of the rock); lenticular channel; internally very thin bedded with planar cross-bedding. Sample $106-1 \ldots \ldots \ldots \ldots, 4.9$

Total measured thickness

\section{LOCALITY 107. ROBINSON CREEK}

SE $\frac{1}{4} \mathrm{NW}_{\frac{1}{2} \mathrm{NE}} \frac{1}{4}$ sec. 5, T. 7 N., R. 10 W.; Powell County; approximately 50 feet from top of the southern slope of Robinson R1dge, 1 mile northwest of Tin Cup Lake. Mapped as Eocene to Oligocene Heterogeneous deposits by Konizeski and others (1968, Pl. 1).

Unit Conglomerate, Iight brown; with rounded cobbles of sandstone
and siltstone $(60 \%)$, shale $(30 \%)$, and granitic conglomerate $(10 \%)$; In a matrix of red sandy silt; hard, compact; ledge former; calcareous cemented; iron-stained and oxidtzed; tabular even; internally massive. Minor carbonaceous

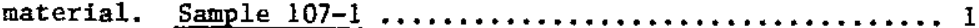

\section{LOCALITY 108. ANACONDA}

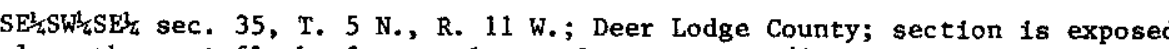
along the west flank of a gentle syncline, about $3 / 4$ mile northeast of the Anaconda Electric power substation. The beds strike northeast and dip approximately $10^{\circ}$ to the east. Mapped as Miocene (?) conglomerate by Wanek and Barclay (1966, P1. 1, p. 15-16), and as Miocene Anaconda beds by Csejtey (1963, P1, 1, p. 41, 47).

Measured Conglomerate $(85 \%)$. Same as unit $2 \ldots \ldots \ldots \ldots \ldots \ldots \ldots \ldots \ldots$
Sandstone $(15 \%)$; silty; tan; very fine grained moderately sorted; medium hard. Lower contact sharp and regular...... 21

3. Siltstone, clayey; streaked light olive gray; medium hard, loose; cliff former; iron-stained; tabular even; with internal parallel even, thin bedding. Lower contact sharp and regular. Minor carbonaceous material. Contains three inch carbonaceous interbeds with abundant wood fibers and plant impressions. Sample $108-3$ taken at the top of the unit $\ldots \ldots \ldots \ldots \ldots \ldots \ldots, 7.7$
LOCALITY 108. (continued)

$\frac{\text { Unit }}{2}$

2. Conglomerate; grayish thick. (ft) zite $(50 \%)$, shale $(30 \%)$, and other rock fragments $(20 \%)$ in a matrix of poorly sorted subangular to subrounded, medium grained, micaceous, sandstone; medium hard, compact; cliff former; calcareous cemented; Iron-stained; lenticular channel; with internal disturbed-irregular, thick bedding. Lower contact sharp and irregular. Thin silt interbeds.

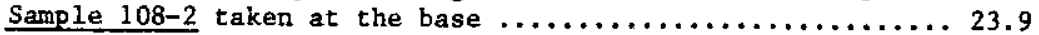

1. Sandstone, silty, micaceous; banded yellowish gray; fine to very fine grained, moderately sorted, with subangular grains; medium hard; compact; cliff former; calcareous cemented; iron-stained; tabular even, with internal parallel even thin bedding. Contains thin silty carbonaceous interbeds. Sample 108-1 from the top of the unit $\ldots \ldots \ldots \ldots \ldots \ldots \ldots \ldots \ldots \ldots \ldots \ldots$

Total measured thickness

\section{LOCALITY 109. MORSE RANCH CREEK}

$\mathrm{SE}^{\frac{1}{4} \mathrm{NW}} \frac{1}{4} \mathrm{SWW}_{4} / \mathrm{sec} .3$, T. $10 \mathrm{~N} .$, R. 12 W.; Granite County; on southeast side of stream drainage, approximately 1 mile east of Morris Creek and about 1 mile north of I-90. Mapped as early Miocene Cabbage Patch Formation by Gwinn (1961).

Unit

Estimated

Claystone, silty; streaked graytsh yellow; (weathers to thick. (ft) nodular surface); hat Internalis mase ;ve, Lower concact covered. internally massive. Lower contact covered. Minor carbonaceous material. Includes thin siltstone beds, Sample

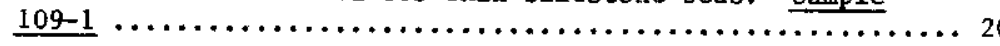

LOCALITY 110. BERT CREEK GRAVEL PIT

$\mathrm{SW}_{\frac{1}{4}} \mathrm{SE}_{\frac{1}{4}} \mathrm{SW} \frac{1}{4}$ sec. 11, T. $10 \mathrm{~N} .$, R. 12 W.; Granite County; on top of hill, approximately $1 / 4 \mathrm{mile}$ west of Bert Creek and approximately $1 / 4 \mathrm{mile}$ north of I-90. Measured section B of MV6549, locality 5 of Rasmussen (1969, p. 159). Type section of Bert Creek Formation (Pllocene) and also representative of the coarse grained part of the Pliocene in the Drummond area.

onglomerate, sandy, light olive gray; with subrounded pebbles of quartzite (50\%), volcanics $(30 \%)$ and granite $(20 \%)$; in a matrix of poorly sorted, very coarse grained, feldspathic sandstone; soft, friable; slope former; manganese stained; tabular even; internally massive. Sample 110-1 .........46

*Thickness from Rassmussen (1969, p. 159) 


\section{LOCALITY 111. BERT CREEK}

$\mathrm{SE}^{\frac{1}{4}} \mathrm{SW}_{\frac{1}{4}} \mathrm{SW}_{\frac{1}{4}}$ sec. $11, \mathrm{~T} .10 \mathrm{~N} .$, R. $12 \mathrm{~W} . ;$ Granite County; in small gulch, approximately $1 / 4 \mathrm{mile}$ northwest of the mouth of Bert Creek. Type section of Cabbage Patch Formation (Rassmussen, 1969, section MV6554, locality 8, p. 152-155).

Messured $\frac{\text { Unit }}{6 .}$ Not described. Unit 32 of Rassmussen, 1969, pp. 152-155.....

5. Sandstone, arkosic, clayey; 11ght olive brown; fine grained, moderately sorted, with subangular grains; soft, friable; slope former; Iron-stained; tabular even; internally massive. Lower contact gradational. Minor amount of heavy minerals. Grade to pebble conglomerate at top. Unit 31 of Rassmussen (1969, p. 152). Sample 111-4 taken at the base.. 9.5

4. Siltstone, micaceous, sandy; yellowish gray; medium hard, compact; slope former; 1ron-stained; tabular even; internally thin-bedded. Lower contact gradational. Minor amount of heavy minerals. Unit 30 of Rassmussen (1969, p. 152).

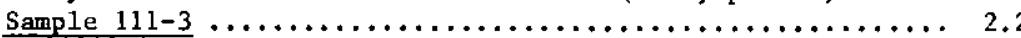

3. Sandstone, arkosic, micaceous; medium dusky yellow; coarse grained, moderately sorted; hard, compact; ledge former; iron-stained; tabular even; with internal parallel even, medium bedding. Lower contact sharp and regular. Contains a few subrounded pebble clasts. Unit 29 of Rassmussen $(1969$, p. 152). Minor amount of opalized wood. Sample 111-2

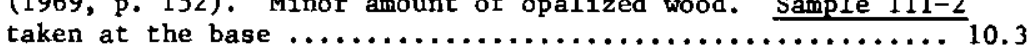

2. Siltstone, clayey, micaceous, tuffaceous; mottled medium yellowish gray; medium hard, compact; slope former; tabular even; internally massive. Unit 28 of Rassmussen (1969, p. 152). Lower contact sharp and regular. Sample 111-1 taken at the top $\ldots \ldots \ldots \ldots \ldots \ldots \ldots \ldots \ldots \ldots \ldots \ldots \ldots \ldots, 0.75$

1. Not described; units 1-27 of Rassmussen, 1969, pp. 152-155... 79.25

Total estimated thickness ............................... 102.0

\section{LOCALITY 112. GRIFFIN CREEK}

SW $\frac{1}{4} \mathrm{NE}_{\frac{1}{4}} \mathrm{NE}^{\frac{1}{4}} \mathrm{sec} .16$, T. 9 N., R. 11 W.; Powell County; unit described is the resistant caprock on many of the low hills in the area. Lithologically similar and time equivalent to units in the Cabbage Patch type section (see discussion of locality 111). Mapped as Miocene sandstone and conglomerate by Mutch (1961).

*Th1ckness from Rassmussen (1969, pp. 152-155).
LOCALITY 112. (cont1nued)

Unit

I. Sandstone, arkosic, ftcaceous; spotted yellowish brow; thfck. (ft) coarse grained, poorly sorted, with subrounded grains; hard, compact; ledge former; siliceous cement; tabular even; with internal parallel even, medium bedding. Contains minor subrounded pebble clasts and heavy minerals. Sample 112-1

\section{LOCALITY 113. NORTH FORK BIG HOLE RIVER}

$\mathrm{NE}_{4}^{\frac{1}{4}} \mathrm{SE}_{\frac{1}{4}} \mathrm{SW}_{\frac{1}{4}}$ sec. 4, T. 2 S., R. 16 W.; Beaverhead County; in gully 200 feet SW of road on the south side of rlver. Mapped as Tertiary sediments by Ross and others (1955). This unit is similar in hardness and lithology to rock units mapped as Pliocene-Pleistocene in other areas of southwest Montana.

$\frac{\text { Unit }}{1}$

Estimated thick. (ft)

Conglomerate $(95 \%)$, sandy; dark yellowish orange; with rounded pebbles of quartzite $(70 \%)$, granite $(30 \%)$, in a matrix of moderately sorted, subrounded, medium to coarse gralned arkosic sandstone; medium hard, compact; slope former; iron-stained and cemented; tabular even, internally thick bedded. Sample 113-2 taken at the base of 10-foot bed at the contact with silty sandstone (sample 113-1).

Sandstone $(5 \%)$, silty, arkosic; uniform dark yellowish orange; medium grained; moderately to well sorted; with subangular grains; medium hard, compact; slope former; iron-stained; medium thick lenticular bed; internally massive. Lower contact with conglomerate is sharp irregular. Iron-stained.

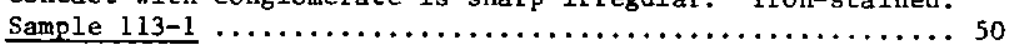

\section{LOCALITY 114. PLIMPTON CREEK}

$\mathrm{SE}_{4}^{1} \mathrm{NE}_{4}^{1} \mathrm{NW} \frac{1}{4} \mathrm{sec} .16$, T. 1 S., R. 15 W.; Beaverhead County; resistant caprock on low hill, 0.3 mile north of Plimpton Creek, in the central part of the Big Hole River valley. Dips within this unit are chaotic. llapped as Tertiary sedimentary rocks undifferentiated by Ross and others (1955).

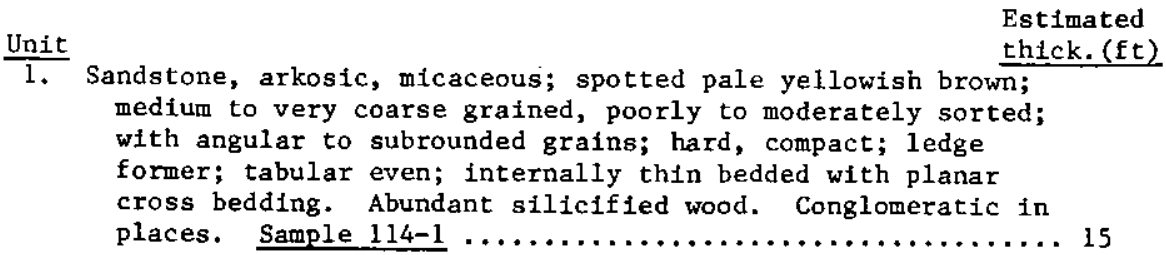




\section{LOCALITY 115. RUBY RANCH ROAD}

NWh of road, 0.2 mile south from Montana Highway 43. Mapped as Tertiary lake beds by Alden (1953, P1. 1)

Conglomerate (95\%); yellowish gray; with subrounded pebbles of Measured quartzite $(90 \%)$, and granite $(10 \%)$; in a matrix of poorly sorted, fine to very fine grained sandstone; hard, compact; ledge former; siliceous cement; tabular even; internally thick bedding. Sample 115-2 taken from middle of unit above silty sandstone lens (sample 115-1).

Sandstone $(5 \%)$, silty, micaceous; yellowish gray; fine to very fine grained, moderately sorted; hard, compact; slope

former; thin, lenticular beds. Sample 115-1 ..........47.0

\section{LOCALITY 116. SWAMP CREEK ROAD}

$\mathrm{NE}_{\frac{1}{4}} \mathrm{NE}_{\frac{1}{4}} \mathrm{NE}_{\frac{1}{4}} \mathrm{sec} .13$, T. 3 S., R. 17 w.; Beaverhead County; roadcut. Mapped as Tertiary lake beds by Alden (1953, P1. 1).

laystone, micaceous, conglomeratic; medium yellowish gray medium hard, compact; slope former; manganese-stained; lenticular bed; with internal parallel even, thin bedding. Lower contact sharp and regular. Trace of heavy minerals. Minor glass shards and fine to coarse grained sand. Sample 116-2 taken of the most carbonaceous part ......... 3

1. Sandstone, clayey, feldspathic, micaceous; streaked 11ght yellowish gray; coarse grained, poorly sorted, with subangular grains; medium hard, friable; slope former; ironstained; tabular even; internal medium bedding.

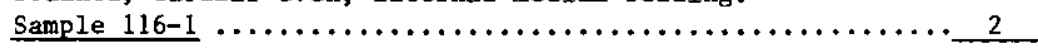

Total estimated thickness $\ldots \ldots \ldots \ldots \ldots \ldots \ldots \ldots \ldots \ldots \ldots, 5$

\section{LOCALITY 117. CHALK BLUFF}

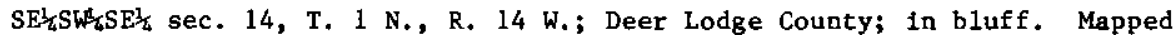
as Tertlary lake beds by Alden (1953, P1. 1).

$\begin{array}{ll}\text { Unit } & \text { Estimated } \\ \text { thick. (ft) }\end{array}$ Claystone (95\%), light tan to light gray; medium hard, compact
slope former; tabular even, internal very thick or massive(?) slope former; tabular even, Internal very thick or massive(?)
bedding. Iron and manganese-stained in manner which does not seem to conform to bedding or channeling.

Siltstone (5\%), clayey; medium grayish yellow; mediun hard; compact; slope former; iron-stalned; thin lenticular beds; internally massive. Subordinate carbonaceous material; minor amount of heavy minerals (?) or manganese oxide (?) Sample $117-1$ from near base $\ldots \ldots \ldots \ldots \ldots \ldots \ldots \ldots \ldots \ldots \ldots . \ldots \ldots$

\section{LOCALITY 118, WISDOM CEMETERY}

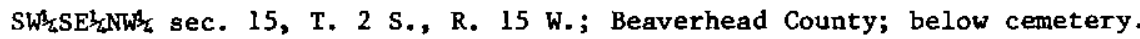
Mapped as Tertiary lake beds by Alden (1953, P1. 1).

$\frac{\text { Unit }}{4 .}$ Estimated

4. Claystone and siltstone, micaceous, sandy; medium hard, compact. (ft) slope and ledge former; tabular even; internally thick bedded.

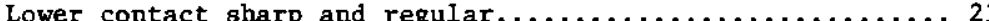

3. Sandstone, feldspathic, micaceous, conglomeratic; pale greenish yellow; fine grained, moderately sorted; with angular grains; soft, friable; slope former; tabular even; with internal parallel even, thin bedding. Lower contact sharp and regular. Contains angular to subangular pebbles and minor amount of glass shards. Sample 118-2 taken at the base ...2 20

2. Claystone, silty; very light gray; medium hard, compact; slope former; tabular even; Internally massive. Lower contact gradational. Trace of carbonaceous material. Sample 118-1 gradational. Trace of carbonaceous material. $\frac{\text { Sample } 118-1}{\text { taken at the top } \ldots \ldots \ldots \ldots \ldots \ldots \ldots \ldots \ldots \ldots \ldots \ldots \ldots \ldots \ldots \ldots \ldots \ldots \ldots}$

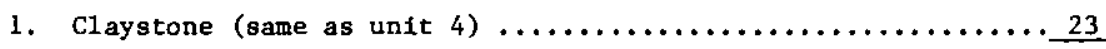

Total estimated thickness 70

\section{LOCALITY 119. MONTANA HIGHWAY 278 No. 1}

$\mathrm{NE}_{4} \frac{1}{4} \mathrm{SE}_{4}^{1} \mathrm{NEE}_{\frac{1}{4}}$ sec. 16, T. 6 S., R. 14 w.; Beaverhead County; in roadcut. Mapped as Tertiary Lake beds by Alden (1953, PI. 1).

Unit

thick. ( $\mathrm{ft}$ ) orange gray; very coarse grained, poorly sorted; very hard; ledge former; iron-stained; tabular even; internally thin-bedded; with cross-bedding. Minor amount of petrified wood...................... 7.0

13. Claystone; medium brownish gray; soft, plastic; slope former; thin to medium thick lenticular bed; with internal parallel even, very thin bedding. Lower contact sharp and regular.

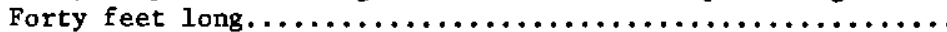

12. Sandstone, feldspathic; streaked light yellowish gray; medium to coarse grained, moderately sorted, with subangular grains; hard, compact; ledge former; 1ron-stained; tabular even; 1nternally medium bedded, with planar cross-bedding. Lower

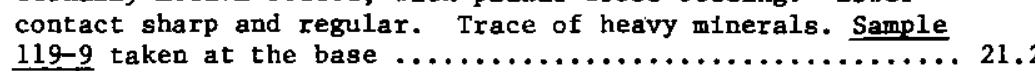

11. Claystone, bentonitic; streaked dark brown; soft, plastic; slope former; Iron-stained; tabular even; with internal parallel even, very thin bedding. Lower contact sharp and regular. 
Measured

Unit

thick. (ft)

11. (cont.) Subordinate carbonaceous material. Sample 119-8

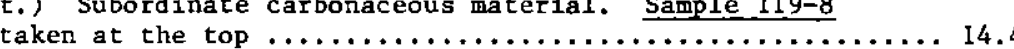

10. Sandstone (50\%), arkosic, micaceous; streaked yellowish orange; coarse to very coarse grained, moderately to poorly sorted, with subangular grains; hard, compact; slope former; tabular even; internally thin bedded, with planar cross-bedding. Contains interbeds of brown carbonaceous clay. Sample 119-7

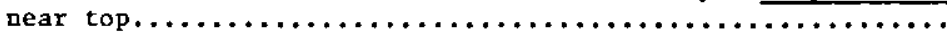

Sandstone $(50 \%)$, arkos $1 \mathrm{c}$, micaceous; streaked medium orange brown; very coarse grained; poorly sorted, with subangular grains; soft, friable; slope former; tabular even; with internal parallel uneven, medium bedding. Lower contact sharp and regular. Sample 119-6 taken at the base, in the

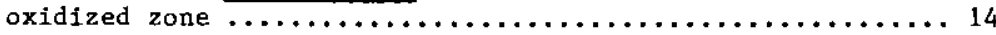

9. Claystone, bentonitic; grayish brown; soft, plastic; slope former; manganese-stained; tabular even; with internal parallel even, thin bedding. Lower contact sharp and regular. Trace of carbonaceous material. Sample 119-5 taken at the top.... 10.1

8. Sandstone, feldspathic, micaceous; dusky yellow; coarse grained, moderately sorted, with subangular grains; soft, frlable; slope former; fron and manganese-stained; tabular even; internally massive. Lower contact sharp and regular. Trace of heavy minerals. Sample 119-4 taken from strongly iron-

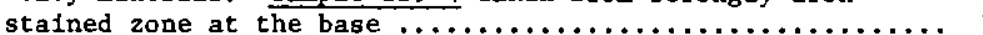

7. Claystone, bentonitic; dark yellowish brown; medium hard, compact; slope former; iron and manganese-stained; tabular even; with internal parallel even, thin bedding. Lower contact sharp and regular. Sample 119-3 taken at the top... 5.8

6. Sandstone, micaceous; streaked medium greenish brown; coarse grained, poorly sorted; soft, friable; slope former; iron and manganese-stained; tabular even; with internal parallel even, thin bedding. Lower contact sharp and regular.

Strongly iron-stained at base........................ 2.7

5. Claystone; streaked medtum greenish brown; medium hard, compact; slope former; iron and manganese-stained; tabular even; with internal parallel even, thin bedding. Lower contact sharp and regular. Trace of carbonaceous material............ 9.0

4. Sandstone; streaked medium greenish brown; coarse grained, poorly sorted; soft, friable; slope former; iron-stained; tabular even; internally massive. Lower contact sharp and regular. Trace of carbonaceous material. Strongly iron-stained at

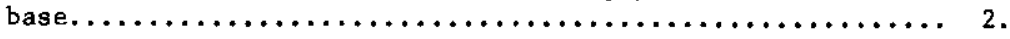

LOCALITY 119. (continued)

$\frac{\text { Unit }}{3+}$

1. former; lron-stained; tabular even; with internal parallel even, very thin bedding. Lower contact sharp and regular. Contalns very thin, greenish gray, medium hard siltstone and soft, coarse grained, poorly sorted, sandstone interbeds... 22.7

2. Sandstone, feldspathic, micaceous; orange brown; coarse to very coarse grained, poorly sorted, with subangular grains; soft, friable; slope former; deeply iron and manganese-stained; tabular even; with internal parallel even, medium bedding. Lower contact sharp and regular. Sample 119-2 taken from strongly 1ron-stained, clayey, and carbonaceous bed at base. 7.0

1. Claystone, micaceous, bentonitic; streaked moderate olive brown; medium hard, plastic; slope former; manganese-stained; tabular even; with internal parallel even, thin bedding.

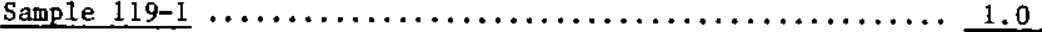

Total measured thickness $\ldots 124.25$

\section{LOCALITY 120. SOUTHEAST JACKSON}

$\mathrm{NE}_{\frac{1}{4} \mathrm{NE}} \frac{1}{4} \mathrm{NE}_{\frac{1}{4}}^{\frac{1}{4}}$ sec. 6, T. 6 S., R. 14 W.; Beaverhead County; on hilltop directly east of locality 121 , on the north side of Highway 278 . Outcrops form hard cap on second level terrace. Mapped as Tertiary lake beds by Alden (1953, PI. 1).

$\frac{\text { Unit }}{1 .}$

Estimated andstone (50\%), micaceous; pale yellowish brown; coarse to very coarse grained, poorly sorted, with angular grains; very hard, compact; ledge former; quartz cement; tabular even; internally thin bedded, with planar cross-bedding. Conglomeratic in places. Minor amount of heavy minerals.

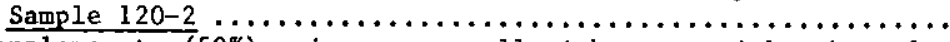

Conglomerate $(50 \%)$, micaceous; yellowish gray; with subangular cobbles of quartzite $(70 \%)$, quartz $(30 \%)$; in a matrix of moderately sorted, medium grained, feldspathic sandstone; hard, compact; ledge former; tabular even; internally thin bedded with planar cross-bedding. Trace of heavy minerals.

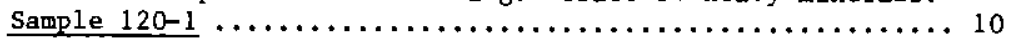

\section{LOCALITY 121. MONTANA HIGHWAY 278 No. 2}

$\mathrm{NW}_{\frac{1}{4} \mathrm{SE}} \frac{1}{4} \mathrm{NE}_{\frac{1}{4}}$ sec. 6, T. 6 S., R. 14 W.; Beaverhead County; in roadcut. Mapped as Tertiary lake beds by Alden (1953, P1. 1). 

gray; coarse to very, arkosic; very micaceous; yellowish gray; coarse to very coarse grained, poorly sorted, with subangular grains; and pebbles of predominantly quartzite and argillite; hard, compact; ledge former; Iron-stained; tabular even; Internally medium bedded, with planar crossbedding. Lower contact gradational. Contains many thin pebble conglomerate beds. Sample 121-2 taken at base.......20

1. Claystone, silty, micaceous; yellowish gray; medium hard, compact; slope former; iron-stained; tabular even; with Internal parallel even, thin bedding. Contains several lenses of medium hard, coarse grained sand. Sample 121-1

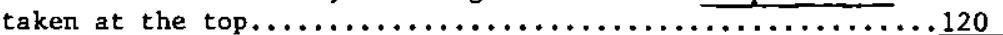

Total estimated thickness

\section{LOCALITY 122. BULL CREEK}

$\mathrm{SE}_{\frac{1}{4}} \mathrm{SW}_{4} \mathrm{SE}_{\frac{1}{2}}$ sec. 36, T. 5 S., R. 15 W.; Beaverhead County; south side of h1ghway 278. Mapped as Tertiary lake beds by Alden (1953, P1. 1).

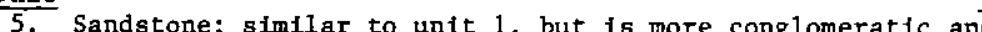
thick. (ft) contalns larger clasts ............................ 15

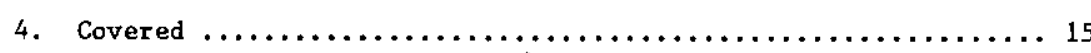

3. Sandstone; simflar to unft 1 , but more conglomeratic and contains larger clasts .............................

2. Covered

1. Sandstone, feldspathic, conglomeratic, micaceous; yellowish gray; coarse to very coarse grained, poorly sorted, with angular to subangular grains, and subangular pebbles of sandstone and quartzite and minor quartz, hard, compact; ledge former; silfceous cemented; tabular even; internally parallel even thin bedded with trough and planar cross-bedding. Trace of heavy minerals. Sample 122-1 ............... I5

Total estimated thickness $\ldots \ldots \ldots \ldots \ldots \ldots \ldots \ldots \ldots \ldots \ldots \ldots$

\section{LOCALITY 123. MEADOW CREEK}

$\mathrm{SE}_{\frac{1}{4}} \mathrm{SW}_{\frac{1}{4} \mathrm{SE}} \mathrm{SE}_{4}$ sec. 32, T. 1 N., R. 11 W.; Beaverhead County; in gulch. Mapped as Tertiary sediments by Fraser and Waldrop (1972).

LOCALITY 123. (cont1nued)

$\frac{\text { Unit }}{1 .}$ Siltstone, clayey; 1ight brownish gray; hard, compact; slopick. (ft)

former; clayey; 1ight brownish gray; hard, compact; slope \begin{tabular}{l} 
former; manganese stained; tabular even; internally massive. \\
Sample $123-1 . \ldots \ldots \ldots \ldots \ldots \ldots \ldots \ldots \ldots \ldots \ldots \ldots \ldots \ldots \ldots \ldots \ldots \ldots \ldots \ldots \ldots$ \\
\hline
\end{tabular}

\section{LOCALITY 124. HIGHWAY 43}

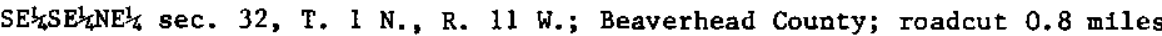
west of Wise River. Mapped as Tertiary sediments by Fraser and Waldrop (1972). 1ltstone, clayey; light brown; soft; Internal very thin Estimated bedding ..................................... 3

2. Conglomerate, very micaceous; medium dusky yellow; with rounded pebble and cobbles of quartzite $(70 \%)$, volcanic rocks (20\%) and granite $(10 \%)$; in a course matrix of poorly sorted, subangular, feldspathic sandstone; soft, friable; slope former; lenticular channel; internally massive. Lower contact sharp and regular. Trace of magnetic minerals. Sample

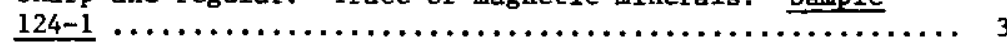

1. Claystone, sandy; greenish brown; soft, frlable; slope former;

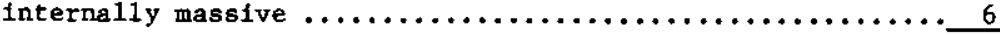

Total estimated thickness $\ldots \ldots \ldots \ldots \ldots \ldots \ldots \ldots \ldots \ldots \ldots \ldots 12$

\section{LOCALITY 125. BITTERROOT RIVER BLUFFS}

$\mathrm{NE}^{\frac{1}{4}} \mathrm{SE}_{\frac{1}{4}} \mathrm{NW} \frac{1}{4}$ sec. 6, T. 10 N., R. 19 W.; Rava111 County; west-facing bluffs between Woodchuck and E1ght Mile Creeks. Two of the thickest sandstone beds and one claystone bed were sampled. Tertiary sedimentary rocks measured and described by McMurtrey (McMurtrey and others, 1972, p. 19-20). (The units of McMurtrey's measured section are numbered, for purposes of this presentation, from the base to the top.)

Unit

described; units 11-17 of McMurtrey (Mclurtrey and others,

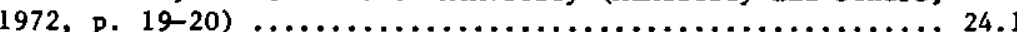

4. Sandstone (50\%); light gray; medium grained, poorly sorted; medium hard; slope former; internally thin bedded, with planar cross-bedding. Containg many thin pebbly channels... Sandstone (50\%), micaceous; streaked orange olive brown; coarae grained, poorly sorted, with subangular grains; Boft, frlable; slope former; 1ron-stained; tabular even; Internally thin bedded with planar cross-bedding. Lower contact sharp and irregular. Trace of heavy minerals. Contains many thin pebbly channels. Units $7,8,9$, and 10 of Mclurtrey (McMurtrey and others, 1972, p. 19-20). Sample 125-3 taken at base... 21.75 
LOCALITY 125. (cont1nued)

$\frac{\text { UnIt }}{3 .}$ Claystone; pale olfve; medium hard, compact; slope former; tabular even; Internally very thin bedded. Lower contact gradational. Carbonaceous. Untt 6 of McMurtrey (McMurtrey and others, 1972 , p. 19-20). Sample 125-2 ............ 8

2. Not described. Units 2-5 of McMurtrey (McMurtrey and others,

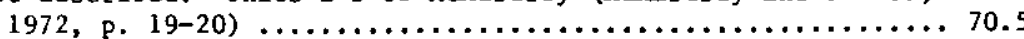

1. Sandstone, feldspathic, slightly micaceous; streaked dark yellowish orange; coarse grained, poorly sorted, with subrounded gra1ns; medium hard, friable; cliff former; 1ron-stained; tabular even; internally thin bedded, with planar crossbedding. Lower contact covered. Contains several thin pebbly channels. Unit 1 of McMurtrey (McMurtrey and others, 1972 , p. 19-20). Sample 125-1 taken at the base in beds with

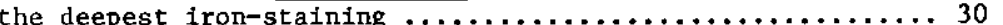

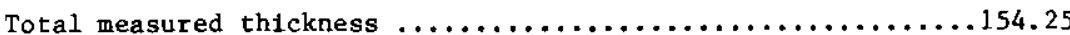

\section{LOCALITY 126. SCHROEDER RANCH}

NW $\frac{1}{4} N_{1} \frac{1}{4} N W / 4$ sec. 30, T. 11 N., R. 19 W.; Missoula County; west-facing river cut west of road. Mapped as Tertiary sedimentary rocks undifferentiated by Ross and others (1955). Mapped by Jerome (1968, P1. 1) as Quaternary sedfments.

$\frac{\text { Un1t }}{4 .}$ Siltstone, clayey; tan; soft to medium hard, friable, slope $\begin{gathered}\text { Estimated } \\ \text { thick. (ft) }\end{gathered}$

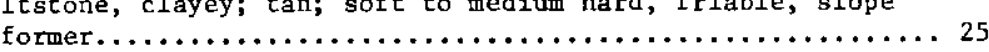

3. Conglomerate, granitic; streaked yellowish gray; with rounded pebbles to boulders of granite (80\%), metamorphic (10\%) and quartzite $(10 \%)$; in a matrix of moderately sorted, subangular, medium grained, arkosic sandstone; medium hard, compact; cliff former; iron-stained; lenticular channel; internally cliff former; iron-stained; lenticular channel; internally and irregular. Minor magnetite. Sample 126-2 taken at

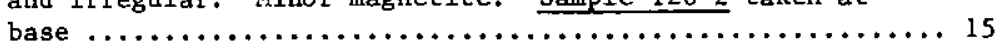

2. Sandstone, clayey, feldspathic, micaceous; medfum yellowish gray; fine grained, poorly sorted; medium hard, compact; ledge former; 1ron-stained; tabular even; internal parallel even, thin bedding. Lower contact covered. Trace heavy minerals. Sample 126-1 taken at top .................

1. Claystone; dark grayish green; medium hard, compact; ledge former $\ldots \ldots \ldots \ldots \ldots \ldots \ldots \ldots \ldots \ldots \ldots \ldots \ldots \ldots \ldots, 1$

Total estimated thickness $\ldots \ldots \ldots \ldots \ldots \ldots \ldots \ldots \ldots \ldots \ldots \ldots$

*Thicknesses from McMurtrey (McMurtrey and others, 1972, p. 19-20).

\section{LOCALITY 127. SPRING GULCH RAILROAD GRADE}

$\mathrm{SE}_{\frac{1}{4}} \mathrm{SW}_{\frac{1}{4}} \mathrm{SE}_{\frac{1}{4}} \mathrm{sec} .30$, T. $10 \mathrm{~N} .$, R. 18 W.; Ravalli County; roadcut on the north side of road. Mapped as Tertiary sedimentary rocks by McMurtrey and others (1972, P1. 1).

$\frac{\text { Unit }}{1 .}$ 1. Sands brown; medium brown; medium grained, poorly sorted, with angular grains; soft, friable; slope former; tabular even; internally massive. Trace of heavy minerals, Sample 127-1 .........

stimated hick. (ft)

\section{LOCALITY 128. SPRING GULCH}

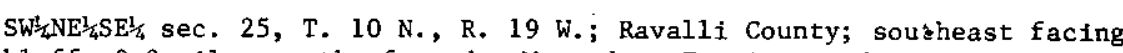
bluff, 0.2 miles north of road. Mapped as Tertlary sedimentary rocks, and measured by McMurtrey and others (1972, P1. 1, p. 15). The following units are the uppermost two units in McMurtrey's measured section which is a total of 227 feet thick.

Siltstone, conglomeratic, sandy, micaceous; yellowish gray with angular pebbles of grante, quartzite, and argilite; hard, compact; ledge former; silicious cemented; manganesestained; tabular even; internally massive. Lower contact gradational. Trace of heavy minerals. Sample 128-2 taken

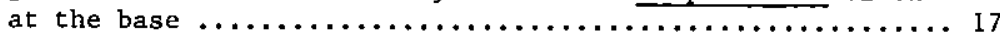

1. Sandstone, silty, feldspathic; yellowish gray; coarse to very coarse grained; poorly sorted; with subangular grains; hard, compact; ledge former; tabular even shape. Internally massive. Lover contact covered. Trace of heavy minerals. Pebbly in places. Sample 128-1 taken at the top ........ 10

Total estimated thickness $\ldots \ldots \ldots \ldots \ldots \ldots \ldots \ldots \ldots \ldots \ldots \ldots$

\section{LOCALITY 129. BITTERROOT CANAL}

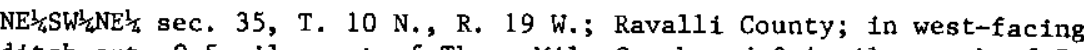
ditch cut, 0.5 mile east of Three Mile Creek and 0.4 mile south of Brown's ranch. Mapped as Tertlary sedimentary rocks by McMurtrey and others (1972, P1. 1).

$\frac{\text { Unit }}{1 .}$ Siltstone, feldspathic, sandy $(60 \%)$; dark grayish orange; thick. (ft) medium hard, compact; slope former; tabular even; internally massive. Minor carbonaceous materlal and heavy minerals.

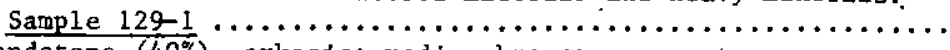
Sandstone (40\%), arkosic; medium brown; coarse to very coarse grained, poorly sorted, with subangular grains; medium hard, friable; slope former; iron-stained; tabular even; internally massive. Trace heavy minerals. Sample 129-2 ........... 15

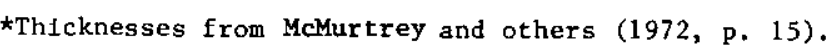




\section{LOCALITY 130, AMBROSE CREEK}

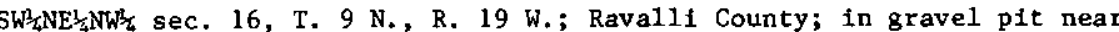
the intersection of two small creeks. Mapped as Tertiary sedimentary rocks by McMurtrey and others (1972, P1. 1).

Sandstone, clayey, micaceous; light olive brown; medium grained,

\section{Estimated}

moderately sorted, with subangular grains; soft, friable;

slope former; lenticular bed; internally very thin bedded,

with planar cross-bedding. Minor replaced carbonaceous

material. Contains many thin to medium conglomeratic channels

with abundant yellow mineralized woody materfal and pebbles

of granite $(50 \%)$, feldspar $(25 \%)$, quartz and volcanic rocks.

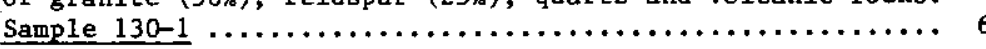

\section{LOCALITY 131. SOUTH FORK WILLOUGHBY CREEK No. 1}

SW $\frac{1}{2} S W^{1} \frac{1}{4} S W^{1} \frac{1}{4}$ sec. 16, T. 8 N., R. 19 W.; Ravalli County; hill slope on northeast side of road. Mapped as Tertiary sedimentary rocks by McMurtrey and others $(1972$, P1. 1).

$\frac{\text { Unit }}{1 .}$

Siltstone, tuffaceous; yellowish gray; hard, compact; cliff

Estimated former; tabular even; Internally massive. Minor carbonaceous material. Contains calcareous nodules, glass shards, some quartzite pebbles, and some pebbles of calcareous siltstone. Also contains several medium thick conglomerate channels.

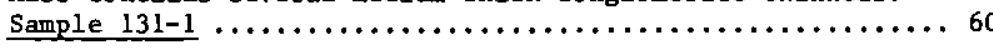

\section{LOCALITY 132. DRY GULCH}

SW $\frac{1}{4} \mathrm{SE}_{4}^{\frac{1}{4}} \mathrm{SW}_{4} \mathrm{sec} .36$, T. 8 N., R. 20 W.; Ravalli County; south-facting stream cut, about 30 feet north of road. Mapped as Tertiary sedimentary rocks by McMurtrey and others (1972, P1. 1) Conglomerate (70\%) clayey; very pale orange; with subrounded
pebbles of quartzite and argillite in a matrix of clay; hard, compact; ledge former; calcareous cement; lenticular channel; Internally massive in medium to thick beds. Lower contact sharp and irregular. Minor heavy minerals. Irregular knobby weathering surface; chaotic bedding attitudes.

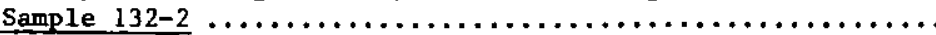

Sandstone $(30 \%)$, silty; yellowish gray; very fine grained. poorly sorted, with angular grains; soft, loose; slope former; calcareous cement; tabular even; internally massive in medium beds. Minor heavy minerals. Sample 132-1 ............ 20

\section{LOCALITY 133. BLODGETT CREEK}

SWL NW $\frac{1}{4} \mathrm{SE} \frac{1}{4}$ sec, 11, T. 6 N., R. 21 W.; Ravalli County; on north side of creek, 0.3 mile east of Blodgett Cemetery. Exposure 100 feet to the east of this location. Consists of 23 feet of tuffaceous, soft to medium hard, carbonaceous siltstone overlain by 15 feet of soft, poorly consolidated gravel. Mapped as Tertlary sedimentary rocks by Mclurtrey and others (1972, P1. 1).

$\frac{\text { Untt }}{2 .}$

Estimated

2. Conglomerate, granitic; dusky yellow; rounded pebbles of granite in a matrix of medium grained, subangular, poorly sorted, feldspathic, micaceous sand; medium hard, friable slope former; iron-stained; tabular even; internally massive. slope former; 1ron-stained; tabular even; internally massive.
Lower contact sharp and regular. Sample 133-2 ...........

1. Siltstone, sandy, micaceous; light gray; medium hard, compact; slope former; tabular even; Internally massive. Sample 133-1 taken at the top $\ldots \ldots \ldots \ldots \ldots \ldots \ldots \ldots \ldots \ldots \ldots \ldots, 3$

Total estimated thickness

\section{LOCALITY 134. ELK CREEK}

SW 3 SW W 3 NW $\frac{1}{4}$ sec. 5, T. 13 N., R. 14 W.; Missoula County; roadcut on southwest stde of road. Mapped as Tertiary basin deposits by Brenner (1964, PI. 1, p. 26-27).

Unit

\section{Estimated}

1. Sandstone, clayey, arkosic; dark yellowish orange; fine to coarse grained, poorly sorted, with subangular grains,

in a clay matrix; hard, compact; slope former; iron-stalned; tabular even; with internal parallel even, very thin bedding. Minor carbonaceous materia1. Sample 134-1 was taken from the upper iron-stained part of the unit..................6 6

LOCALITY 135. HIGHWAY 20 No. 1

$\mathrm{NW}_{2} \mathrm{NW} \frac{1}{4} \mathrm{SW} / \frac{3}{4}$ sec. 17, T. $13 \mathrm{~N} .$, R. 15 W.; Missoula County; in roadcut. Mapped as Tertfary basin deposits by Brenner (1964, P1. 1, p. 26-27).

Unit Estimated

I. Siltstone, clayey; streaked very pale orange to massive gray and brown; hard, compact; slope former; iron and manganesestained; tabular even; Internally massive. Minor carbonaceous material. Sample 135-1 taken from the most carbon-

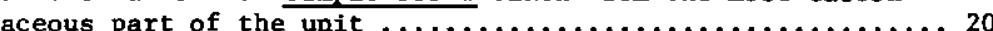




\section{LOCALITY 136. NUMBER FIVE DITCH}

$\mathrm{SW}_{4} \mathrm{NW}_{4} \mathrm{NW}_{1} / 4$ sec. 32, T. $13 \mathrm{~N} .$, R. 11 W.; Powell County; on southeast side of bluff, by an intermittent tributary to ditch. Mapped as Tertiary sediments by Ross and others (1955).

Unit

Siltstone (50\%), clayey, micaceous; streaked light olfve gray;

mediun hard, colpact; mlcaceous; streake even; internally massive. Minor carbonaceous material.

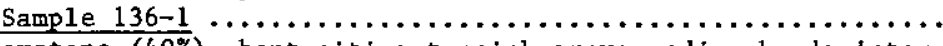

Claystone (40\%), bentonitic; tannish gray; medium hard; internally massive. Trace of carbonaceous materlal. Weathers to a soft, friable surface.

Sandstone (10\%); medium orange brown; fine grained; poorly sorted; with subangular grains; soft, friable; slope former; ironstained; tabular even; internally massive. Trace of heavy

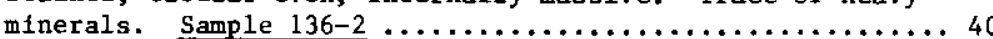

\section{LOCALITY 137. STATE HIGHWAY 271}

$\mathrm{SE}_{4}^{\frac{1}{4} \mathrm{SW}} \frac{1}{4} \mathrm{SW} \frac{1}{4}$ sec. 26 , T. 12 N., R. 12 W.; Powell County; in roadcut on east side of highway. Mapped as Tertiary sedimentary rocks undifferentiated by Ross and others (1955). Konzeski (1961, p. 1633-1641) reports an Early oligocene age for the sediments, from vertebrate fauna collected in the valley.

Unft

Claystone, silty; medium browntsh gray; medium hard, compact;
slope former; manganese stained; tabular even; internally

Estimated

massive. Sample $137-1 \ldots \ldots \ldots \ldots \ldots \ldots \ldots \ldots \ldots \ldots \ldots, 5$

\section{LOCALITY 138. TROUT CREEK}

$\mathrm{SW}^{\frac{1}{4}} \mathrm{SW}^{\frac{1}{4} \mathrm{SE}} \frac{1}{4}$ sec. 1, T. 9 N., R. 8 W.; Powell County; on south-facing hillside, 500 feet north of road. Mapped as Tertiary sediments by Ross and others (1955). Miocene-Pliocene according to paleontological work by Douglass (1902, p. 239) south of Avon.

Unit

aystone, sllty; medium reddish brown; medium hard, compact; slope former; tabular even; internaliy massive. Trace carbonaceous material. Contains minor volcanic sand grains.

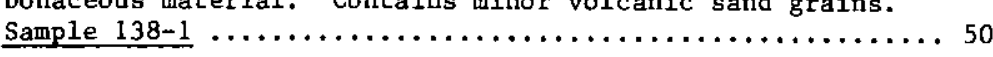

\section{LOCALITY 139. ILLINOIS GULCH}

SE $\frac{1}{4} N_{W} \frac{1}{4} S W \frac{1}{4}$ sec. 25, T. II N., R. 8 W.; Powell County; in canal cut on north slde of road, 0.8 mile southwest of Blackfoot City. Mapped as Tertiary sediments by Ross and others (1955).

\section{LOCALITY 139. (continued)}

Unit

Estimated

1. Sandstone, clayey, micaceous; light olfve gray; medium grained, poorly sorted with subangular grains, in a clay matrix; soft, frlable; slope former; tabular even; internally massive. Minor carbonaceous material and heavy minerals. Contains some granite pebbles. Sample 139-1 ............

\section{LOCALITY 140. AVON GRAVEL PIT}

NWh $\frac{1}{4} \mathrm{NWW}_{4} \mathrm{sec}$ se 15, T. 10 N., R. 8 W.; Powell County; at the contact of Tertiary sedimentary rock undifferentiated and Tertiary volcanics according to Ross and others (1955). Samples were taken from the most radioactive part of the altered volcanics (unit I) and from volcanic breccia (unit 2).

- Breccia volcanic; light brownish red; with angular cobbles of volcanic rock in a matrix of poorly sorted angular sandstone; medium hard, compact; slope former; 1rregular shape internally massive. Lower erosional contact sharp and

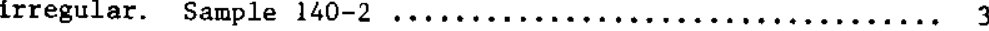

I. Volcanic rock, hydrothermally altered; streaked yellowish red; soft to medium hard; friable to compact. Sample 140-1 taken

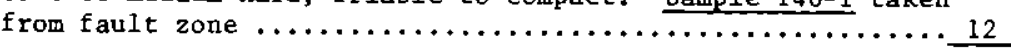

Total estimated thickness 15

\section{LOCALITY 141. SIX MILE CREEK}

NWh $\mathrm{NW}_{4} \mathrm{SW} \frac{\mathrm{L}}{4}$ sec. 32, T. 11 N., R. 8 W.; Powell County; in lower terrace on th. east side of the Avon Valley. Mapped as Tertiary sediments by Ross and others (1955). Oligocene according to paleontological work by Douglass (19C p. 239) in an area a few miles north of Avon.

Unit

Estimated

1. Claystone; light ollve brown (weathers to light brown); soft plastic; slope former; manganese stalned; tabular even; internally massive. Minor carbonaceous material. Sample

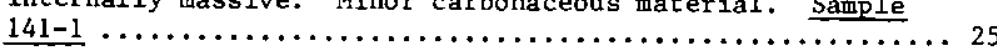

\section{LOCALITY 142. NEW CHICAGO}

$\mathrm{SE}_{4}^{1} \mathrm{NE}_{4}^{\frac{1}{4} \mathrm{NE}_{4}^{1}}$ sec. 17, T. 10 N., R. 12 W.; Granite County; west side of road. Mapped as Flint Creek beds (Miocene to Pliocene) by Gwinn (1960). Strike N. $55^{\circ}$ W. , $18^{\circ}$ to the south. 
Estimated

thick. ( $f t$ )

Unit

Siltstone (90\%), tuffaceous; dusky yellow; medium hard, compact
slope former; tron and manganese stained; tabular even; with internal parallel even thin bedding. Minor carbonaceous material and trace of heavy minerals. Contains load casts at contact with sandstone and manganese dendrites assoclated with carbonaceous material. Sample 142-1 ..............

Sandstone (10\%), tuffacous; 1ight ollve gray; very fine grained, moderately well sorted; soft, frlable; slope former; ironstained; tabular even; with internal parallel even, thin

bedding. Minor carbonaceous material and subordinate heavy

minerals. Sample 142-2 taken from contact with siltstone... 40

\section{LOCALITY 143. WILLOW CREEK}

NE $\xi_{4} \mathrm{SE}_{\frac{1}{4} \mathrm{NW} / 4}$ sec. 30, T. 7 N., R. 15 W.; Granite County; roadcut. Mapped as Tertiary sediments by Ross and others (1955).

Conglomerate, micaceous; yellowish orange; with subrounded cobbles of quartzite and argillite $(90 \%)$; siltstone, conglomerate and volcanics $(10 \%)$; in a silt matrix; medium hard, compact; ledge former; 1ron-stained; tabular even; internally

\section{LOCALITY 144. ANTELOPE CREEK}

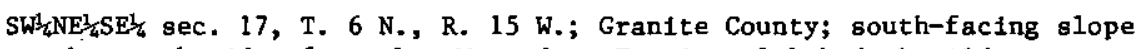
on the north side of creek. Mapped as Tertlary lakebeds by Alden (1953, P1. 1).

Unit

1. Conglomerate; pale yellow; with rounded pebbles of quartzlte and axgillite in a matrix of moderately sorted, subrounded, coarse to very coarse grained sandstone; hard, compact; cliff former; strongly iron-stained; lenticular channel; internally medium bedded, with planar cross-bedding. Contalns many medium thick lenticular conglomeratic sandstone beds.

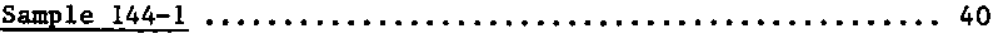

\section{LOCALITY 145. WEST FORK ROCK CREEK}

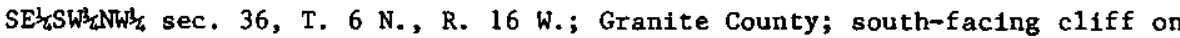
the north side of road. Mapped as Quaternary gravel by Ross and others (1955); this unit is considered by us to be Tertiary because of its hard well-cemented nature and 1ithologic similarity to sediments mapped as Tertiary to the south near the McDonald Mine.

\section{LOCALITY 145 . (continued)}

$\frac{\text { Unit }}{1 .}$ Conglomerate; streaked grayish red; with rounded cobbles of quartzite and argillite in a matrix of poorly sorted arkosic sandy claystone; very hard, compact; cliff former; silfca and chert cement; iron and manganese-stained; tabular even

internally massive. Sample $145-1$...................200

\section{LOCALITY 146. BACON DITCH}

$\mathrm{NE}_{4}^{\frac{1}{4} \mathrm{NW}} \frac{1}{4} \mathrm{NW} \frac{1}{4} \mathrm{sec} .26$, T. 2 N., R. 13 W.; Deer Lodge County; south-facing ditch cut, about 100 feet west of forest service road. Mapped as Tertiary sedimentary rocks undifferentiated by Ross and others (1955).

Unit

Conglomerate; pale olfve; with subrounded pebbles of pre-

Estimated thick. ( $\mathrm{ft}$ ) domtnantly quartatte and minor volcanics da a matrix of poorly sorted, subangular, medium grained sandy clay; medium hard, compact, slope former; tabular even; internally massive. Minor carbonaceous material. Sample 146-1 ..... 6

\section{LOCALITY 147. LA MARCHE CREEK}

$\mathrm{NW}_{4} \mathrm{SW}_{4} \mathrm{NW} \frac{\mathrm{d}}{4}$ sec. 26, T. 2 N., R. 13 W.; Deer Lodge County; next to the forest service road. Mapped as Tertiary sediments by Ross and others (1955).

$\frac{\text { Unit }}{1 .}$ Estimated

1. Interbedded silts and clays (60\%); soft; slope former, with

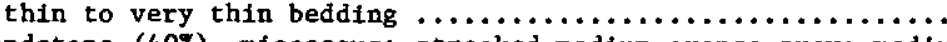
Sandstone $(40 \%)$, micaceous; streaked medium orange gray; medium

to coarse grained, poorly sorted; with subangular grains; soft, friable; slope former; 1ron-stained; tabular even;

internally massive. Sample $147-1 \ldots \ldots \ldots \ldots \ldots \ldots \ldots \ldots$

\section{LOCALITY 148. FRENCH CREEK}

$\mathrm{SW}_{4} \mathrm{SEE}_{4}^{\frac{1}{4} \mathrm{SE}^{\frac{1}{4}} \mathrm{sec} .}$ 3, T. 2 N., R. 12 W.; Deer Lodge County; steep stream cut west of French Creek. Mapped as Tertiary sediments by Ross and others (1955).

Unit

Estimated thick.( $\mathrm{Et})$

- Tuffaceous siltstone/vitric tuff (95\%); light to medium gray and brown; medium hard to hard, compact; cliff former; ironstained; tabular even; with internal parallel even, very thin to medium bedding. Lower contact sharp and regular. Minor heavy minerals. Large variation in amount of carbonaceous material. Contains claystone interbeds which are light gray, medium hard, medium to thick bedded, iron and manganesestained. Also contalns two medium thick tuff beds.

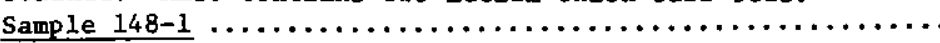


LOCALITY 148. (contInued)

Unit

1. (cont.) Sandstone (5\%), arkosic, micaceous; light ollve brown; medium to coarse grained, poorly sorted; with subangular grains; soft, friable; slope former; iron-stained; lenticular bed; with internal parallel even, medium bedding. Trace of

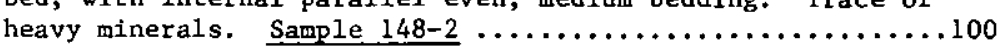

\section{LOCALITY 149. HOME RANCH}

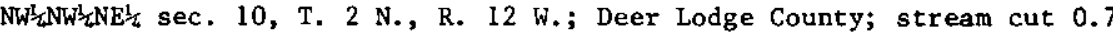
mile east of ranch and 0.2 mile southwest of locality 148. Mapped as Tertiary sedimentary rocks undifferentiated by Ross and others (1955). tstone, micaceous; streaked medium greenish brown; medium hard, compact; slope former; Iron-stained; tabular even; with internal parallel even thick bedding. Lower contact sharp and regular.................................. 15.6

4. Sandstone, volcanic, silty; 1ight brownish gray; very coarse grained, poorly sorted; with subrounded grains; medium hard, friable; ledge former; tabular even; internally thin bedded, with planar cross-bedding. Lower contact sharp and regular...................................... 4.0

3. Claystone, sandy; medium brownish gray; soft, plastic; slope former; tabular even; with internal parallel even, medium bedding. Lower contact gradational................... 9.3

2. Sandstone, micaceous, conglomeratic; banded moderate olive brown (weathers to uniform medium gray); medium to coarse grained, poorly sorted, with subangular grains and subrounded pebbles of quartzite; soft, friable; slope former; iron-stained; tabular uneven; with internal parallel even, thin bedding. Lower contact gradational. Trace of heavy minerals. Sample $149-2$ taken at the base $\ldots \ldots \ldots \ldots \ldots \ldots \ldots \ldots \ldots \ldots .2$

1. Siltstone, clayey; medium yellowlsh brown (weathers to medium brownish gray); medium hard, compact; ledge former; tabular even, with internal parallel even, medium bedding. Minor to trace carbonaceous material. Contains several medium thick beds of gray volcanic ash. Sample 149-1 taken at the top...35.3

\section{LOCALITY 150. PRAIRIE GULCH}

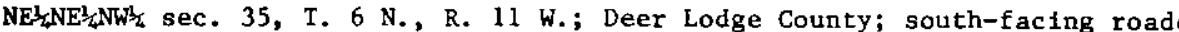
Strike N. $340^{\circ} \mathrm{W}$. and dip $21^{\circ}$ to the west. Mapped as Modesty Creek beds (Mlocene-Pliocene) by Csejtey (1963, P1. 1, p. 48 thru 51).

$\frac{\text { Unit }}{1 .}$

Conglomerate, metamorphic; grayish orange; with subrounded cobbles of quartzite and argillite (95\%) and volcanics $(5 \%)$; In a sandy silt matrix; hard, compact; ledge and pinnacle former; calcareous cemented; iron-stained; tabular even; with internal parallel uneven medium bedding. Contains several hard, iron-stained, siltstone interbeds. Sample

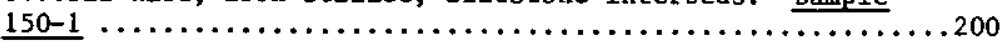

\section{LOCALITY 151. SAND HOLLOW}

$\mathrm{SE}_{4}^{1} \mathrm{NW}_{\frac{1}{4}} \mathrm{SE}_{\frac{1}{4}}$ sec. 21, T. 6 N., R. 9 W.; Deer Lodge County; west-facting bluff, on east side of Clark Fork River. Mapped as Pliocene fluvial deposits by Konlzeski and others (1962, Pl. 1).

Unit 1 tstone ( $80 \%)$, sandy, tuffaceous, micaceous, conglomeratic;
light grayish brown; with subangular pebbles of granite $(70 \%)$, and volcanic rocks $(30 \%)$; soft to medium hard, compact; slope former; tabular even; with internal parallel even, thin bedding. Lower contact sharp and irregular. Minor amount of heavy minerals. Contains glass shards.

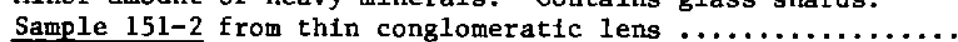
Sandstone (20\%), arkosic, micaceous; dark grayish orange; coarse grained, poorly sorted; with subangular grains; soft, friable; slope former; tabular even; medium thick; with internal parallel even, thin bedding. Lower contact with siltstone sharp and regular. Minor amount of heavy minerals

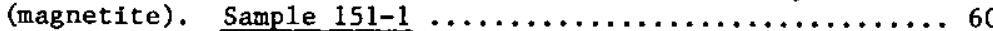

\section{LOCALITY 152. ROCK CREEK DITCH}

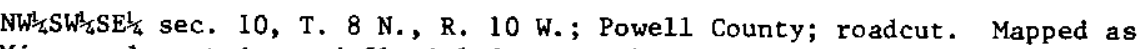
Miocene lacustrine and fluvial deposits by Konizeski and others (1962, P1. 1, Pp. 13-16).

1. Claystone (90\%), brown, pink and green; soft to medium hard Estimated plastic to frangible; slope former; with internal parallel even medium bedding.

Sandstone (10\%), medium brownish gray; fine to very fine grained, moderately sorted; hard; ledge former; internally very thin bedded with planar cross-bedding. Lower contact with claystone is sharp, regular ...................... 20 stimated ck. (ft) 
NE $\frac{1}{4} \mathrm{NE}_{4} \frac{1}{4} \mathrm{NE} \frac{1}{4} \mathrm{sec} .8$, T. 7 N., R. 8 W.; Powell County; roadcut. Mapped as Miocene lacustrine and fluvial deposfts by Konizeski and others (1962, PI. 1, Pp. 13-16).

Unit

Estimated

4.

laystone, silty, micaceous; greenish gray; with green and yellow streaks; soft; slope former; tabular even. Lower contact sharp and regular. Minor biotite $\ldots \ldots \ldots \ldots \ldots \ldots 30$

3. Sandstone, micaceous; greenish gray with yellowlsh green streaks; fine grained, moderately sorted; hard; slope former; tabular even; with internal, parallel even, thin bedding. Lower contact sharp, regular. Subordinate biotite. Contalns several very thin interbeds, of hard siltstone (fisgile) ... 3

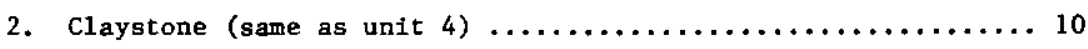

1. Conglomerate, volcanic, greenish brown; with subrounded cobbles of basalt and rhyolite in a matrix of silicic medium grained sandstone; hard; slope former; tabular even .............4

Total estimated thickness

\section{LOCALITY 154. GOLD CREEK}

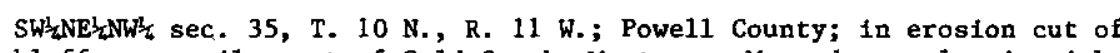
bluffs, one mile west of Gold Creek, Montana. Mapped as volcanic rich silts and clays by Mutch (1961).

Claystone and siltstone, conglomeratic; tan-light gray; with rounded to subrounded pebbles of volcanic rocks $(50 \%)$,

limestone $(40 \%)$, and quartzite $(10 \%)$; hard; slope former;

tabular even; internally masstve...................... 20

\section{LOCALITY 156. SHERRY TOP SWITCHING STATION}

NE $\frac{1}{2} \mathrm{NE}_{4}^{1} \mathrm{SE}_{2}^{1} \mathrm{sec}$. 19, T, $10 \mathrm{~N}, \mathrm{R}, 12 \mathrm{~W}$; Grantte County; in erosion cut under power lines in northwest-facing bluffs. Mapped as Flint Creek formation by Gower lines 1 in

\footnotetext{
$\begin{array}{ll}\text { Unit } & \text { Estimated } \\ \text { thick. (ft) }\end{array}$

1. Siltstone, and claystone; tan to light gray; soft to medium hard; slope former; internally massive. Siltstone contains $10-20 \%$ nodular silty 11mestone $\ldots \ldots \ldots \ldots \ldots \ldots \ldots \ldots \ldots, 50$
}

\section{LOCALITY 157. BARNES CREEK GRAVEL PIT}

WN $\frac{1}{2} \mathrm{NE}_{2}^{\frac{1}{2}} \mathrm{NE}_{\frac{1}{4}}^{\frac{1}{4}} \mathrm{sec}, 31$, T. 10 N., R. 12 W.; Gran1te County; Mapped as Baraes Creek gravel by Gwinn (1961). $\frac{\text { Unit }}{1 .}$ Sandstone (50\%), conglomeratic; tan; coarse grained, poorly sorted, with pebbles; soft, unconsolidated; slope former internally thin bedded, with planar cross-bedding.

Gravel (50\%); tan; with pebbles in a matrix of poorly sorted, coarse grained, sandstone; soft; slope former; internally thin bedded, with planar cross-bedding $\ldots \ldots \ldots \ldots \ldots \ldots \ldots, 8$

\section{LOCALITY 158. ALLENDALE DITCH}

$\mathrm{SW}_{3} \mathrm{NE} \frac{1}{4} \mathrm{SW} / \frac{1}{4}$ sec. 2, T. $10 \mathrm{~N} .$, R. $13 \mathrm{~W}$; Granite County; in stream cut, one mile west of the Drummond Radio Range Station. Mapped as Tertiary sedimentary rocks undifferentiated by Ross and others (1955). y fisile. Lowe contact sharp, regular. Trace of carbonaceous materfal

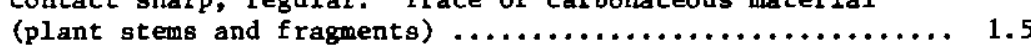

3. Claystone; brownish yellow, with dark gray and black speckles of manganese stain; medium hard; slope former; internally thin bedded. Lower contact sharp, regular ................ 1

2. Shale, (same as unit 4) $\ldots \ldots \ldots \ldots \ldots \ldots \ldots \ldots \ldots \ldots \ldots, 5$

1. Siltstone, sandy, conglomeratic, calcareous; tan; with angular pebbles of limestone; medium hard; internally massive. Contains a few thin planar cross-beds...................

Total estimated thickness

\section{LOCALITY 159. MORSE RANCH}

NWB $\mathrm{SE}_{\frac{1}{4}} \mathrm{SE}_{\frac{1}{4}}$ sec. 3, T. 10 N., R. 12 W.; Granite County; in gully. Mapped as Cabbage Patch formation by Gwinn (1961), and Rasmussen (1969, P1. I, pp. 21-79).

Unte

Estimated

1. Claystone; tan to light gray; medium hard; slope former; thick. (ft) 20

\section{LOCALITY 160. MORRIS CREEK}

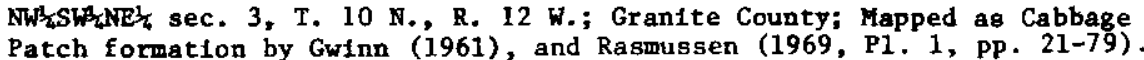


LOCALITY 160. (contInued)

$\underline{\text { Untt }}$

1. Claystone; tan to 11ght gray; medium hard; slope former

Estimated

thick. (f.t)

Internally massive............................ 15

\section{LOCALITY 165. PINTLAR CREEK}

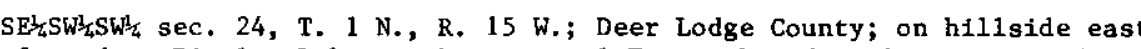
of road to Pintlar Lake at the National Forest boundary 1ine. Mapped as Tertiary sedimentary rock undifferentiated by Ross and others (1955).

Unit

Estimated

1.

Siltstone, reddish tan; hard; ledge former; manganese stained;

ick. $(f t)$ internally massive...........................

\section{LOCALITY 166. NORTH BENCH No. 1}

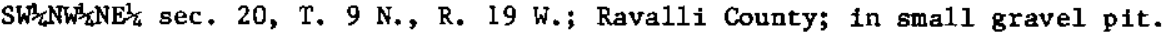
Mapped as Tertiary sedimentary rocks by McMurtrey and others (1972, P1. 1). Estimated thick. (ft) Unit

Sandstone, arkosic, conglomeratic; tan to gray; coarse-grained, moderately to poorly sorted, with subangular grains and pebble and cobble clasts of granite and sandstone; soft, internally medium bedded........................... 10

\section{LOCALITY 167, NORTH BENCH No. 2}

$\mathrm{NW}_{4} \mathrm{SW}_{\frac{1}{4} \mathrm{NW}} \mathrm{H}_{4}$ sec. 21, T. 9 N., R. 19 W.; Raval11 County; in garbage pit. Mapped as Tertiary sedimentary rocks by McMurtrey and others (1972, P1. 1).

Unit Estimated thick. (ft)

1. Vitric tuff (?), (tuffaceous sandstone); 1ight gray; very fine grained, well sorted; soft; very thin to thin bedding........

\section{LOCALITY 171. JOHNSON'S GULCH GRAVEL PIT}

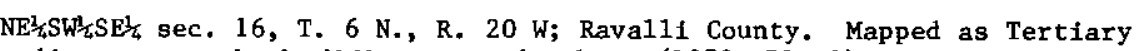
sedimentary rocks by McMurtrey and others (1972, P1. 1)

$\underline{\text { Unit }}$

Estimated

1. Sandstone (60\%), arkostc; light gray; coarse grained, poorly sorted, with angular to subangalar grains; soft, with internal medium planar, cross-bedding. Lower contact sharp,

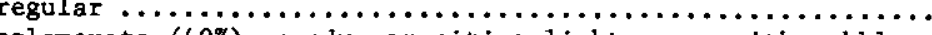
Conglomerate (40\%), sandy, granitic; light gray; with pebbles of granite (50\%), quartzite and argilite $(50 \%)$, in a matrix of poorly sorted, coarse grained, arkosic sandstone; soft; forms medium thick lenticular channels. Lower contact sharp,

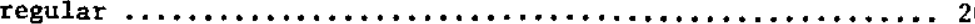

\section{LOCALITY 172. BITTERROOT IRRIGATION CANAL No. 2}

NE $\frac{1}{4} \mathrm{NE}_{4} \mathrm{SE}_{\frac{1}{4}}$ sec. 14, T. 6 N., R. 20 W.; Ravalli County. Mapped as Tertiary sedimentary rocks by McMurtrey and others (1972, PI. 1).

Unit

Siltstone $(90 \%)$ brown, med carbonaceous material.

Sandstone (10\%), conglomeratic, arkosic; 1ight gray; coarse

Estimated thick. (ft) grained, poorly sorted, with pebbles; soft; lenticular

channel. Lower contact with siltstone sharp, regular ...... 15

\section{LOCALITY 177. DOUGLAS CREEK}

$\mathrm{NE}^{\frac{1}{4}} \mathrm{SW}_{\frac{1}{4} \mathrm{NE}}^{\frac{1}{4}}$ sec. 20, T. 12 N., R. 12 W.; Powell County; roadcut near a small lake. Mapped as Tertiary sedimentary rocks undfferentiated by Ross and others (1955)

Unit

Estimated

1. Siltstone, tuffaceous, bentonitic; tan to gray with gray streaks; medium hard; slope former; tabular even with internally massive beds. Minor carbonaceous material in vugs and fractures associated with manganese staining. Weathers to nodules and knobby surface features ................., s

\section{LOCALITY 179 . HIGHWAY 271}

$\mathrm{NWB}_{4} \mathrm{NW}_{4} \mathrm{NWB} / 4$ sec. 26, T. 12 N., R. 12 W.; Powell County; roadcut on the eas sfde of highway. Mapped as Tertiary sedimentary rocks undifferentiated by Ross and others (1955) and Tertiary lake beds by Shea (1947, P1. 1).

Kon1zeski (1961, p. 1633-1641) gives an Early 0ligocene age from vertebrate Konizes

$\frac{\text { Unit }}{1 .}$ Estimated thick. $(f t)$

- Claystone; light gray to tan; medium hard; slope former; tabular even, and internally massive. Trace of carbonaceous material assoclated with manganese staining $\ldots \ldots \ldots \ldots \ldots 25$

\section{LOCALITY 180. SPOTTED DOG CREEK}

NW $\frac{1}{4} \mathrm{SE}_{\frac{1}{4}} \mathrm{SE}_{\frac{1}{4}}$ sec. 27 , T. 10 N., R. 8 W.; Powell County; stream cut, 1 mile southeast of Avon, Montana. Mapped as Tertiary sedimentary rocks undifferentiated by Ross and others (1955).

$\frac{\text { Unit }}{1 .}$

Siltstone, sandy; brownish gray; soft, frlable; slope former; internally massive. Sand grains are subrounded and volcanic

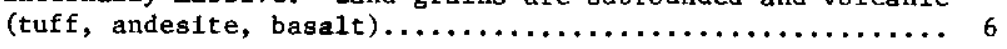




\section{LOCALITY 181. AVON}

NE $3_{4} \mathrm{NE}_{4}^{\frac{1}{4}} \mathrm{SE}_{\frac{1}{4}}$ sec. 21, T. 10 N., R. 8 W.; Powell County; roadcut on state h1ghway $271,0.4 \mathrm{mile}$ north of Avon, Montana. Mapped as Tertiary sedimentary rocks undifferentiated by Ross and others (1955).

Unit

Claystone (95\%), sandy, bentonitic; red, gray, and tan; sof to medium hard, plastic; slope former; tabular even with internal parallel even, thin beds. Minor carbonaceous materfal. Contains volcanic clasts which have weathered to

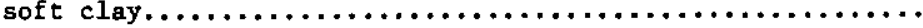
Sandstone (5\%); tan to gray; medium gralned, poorly sorted, soft; with clayey matrix; slope former; lenticular......... 15

\section{LOCALITY 183. HALFWAY CREEK}

NW $\frac{1}{4} \mathrm{SE}_{\frac{1}{4}} \mathrm{SEE}_{\frac{1}{4}}$ sec. 35, T. 12 N., R. 9 W.; Powell County; on bluff on the east side and adjacent to highway 271 . Mapped as Tertiary sedimentary rocks undifferentiated by Ross and others (1955).

\section{Estimated}

thick. (ft)

2. Siltstone (95\%); tan; soft; sticky; medium to thick bedding.

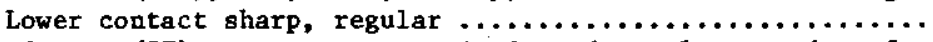

Sandstone (5\%); tan; coarse grained, moderately sorted; sof $t$,

lenticular; with internal very thin bedding $\ldots \ldots \ldots \ldots \ldots . .10$

1. Claystone (same 1fthologic description as locality 182, and locality 141) .................................. 30

Total estimated thickness

\section{LOCALITY 188. DEEP CREEK}

$\mathrm{SW}_{\frac{1}{4}} \mathrm{SE}_{\frac{1}{4} \mathrm{NE}^{\frac{1}{4}}} \mathrm{sec}$. 9, T. 2 N., R. 12 W.; Deer Lodge County; in small grave1 pit. Mapped as Tertiary sedimentary rocks undifferentiated by Ross and others (1955).

$\frac{\text { Unit }}{2}$ Sandstone, conglomeratic; orange to brown with rusty to orange

Estimated iron streaks and bands; very coarse grained; poorly sorted; with subrounded pebbles; medium hard; slope former; tabular even; with internal parallel even, thin to medium bedding. Lower contact sharp, regular $\ldots \ldots \ldots \ldots \ldots \ldots \ldots \ldots \ldots \ldots, 4$

1. Claystone; gray to brown; soft; slope former; tabular even; with internal parallel even, thin bedding .................. 2

\section{LOCALITY 189. TRAIL CREEK}

SWl $\mathrm{SE}_{4} \mathrm{NW} / 4 \mathrm{sec}$. 14, T. 5 N., R. 15 W.; Granite County; in stream cut on the south side of highway 28 . Mapped as Tertiary clays - chiefly montmorillonite by Poulter (1956).

Uni

Claystone, montmorillonitic; buff to reddish brown; soft,

Estimated thick. (ft) sticky, plastic, slope foraer; tabular even; internally massive. Contains a few very thin pebbly interbeds........ 10

LOCALITY 190. PORTERS CORNER

NWh $\mathrm{SE}_{4} \mathrm{SE}_{\frac{1}{4}}$ sec. 22, T. 6 N., R. 14 W.; Granite County; poorly exposed section in roadcut on the east side of U.S highway 10-A, 0.2 mile north of Porters Corner, Montana, but similar in lithology to Tertiary clays - chiefly montmorillonite of Poulter (1956).

$\frac{\text { Unit }}{1 .}$

Estimated

- Claystone (70\%), montmorillonitic; cream to reddish brown soft to medium hard, sticky, plastic; slope former.

Sandstone (30\%), micaceous; tan to gray; coarse grained, poorly sorted; soft; slope former; tabular even. Lower contact

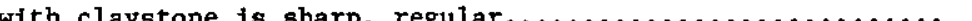

\section{LOCALITY 201. SUNLIGHT MINE}

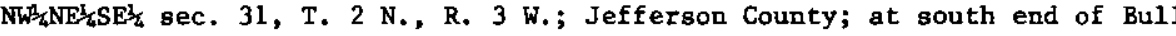
Mountain, south of Sunlight Mine. Units 1 and 2 described below correspond to units 2 and 3, respectively, of measured section number 6 of Kuenzi (1966, p. 269). Climbing Arrow Member of Renova Formation.

2. Conglomerate, granite; yellowish gray; with rounded pebbles in a matrix of moderately sorted, very coarse grained, arkosic sandstone; very hard, compact; ledge former; low permeability; tabular even; internal parallel even, thin bedding. Lower contact sharp, regular. Minor biotite and some smokey quartz. Sample $201-2 \ldots \ldots \ldots \ldots \ldots \ldots \ldots \ldots .4$

1. Claystone; light olive gray (weathers to light gray); soft, plastic; slope former; internal parallel even, medium thick bedding. Trace carbonaceous material. Sample 201-1.. .6

Total estimated thickness 


\section{LOCALITY 202. MAYFLOWER GULCH}

NWt $W^{2} W_{2}^{2}$ SW sec. 17, T. 1 N., R. 3 W.; Madison County; NE rim of Parrot Bench on west side of gulch. Unit described below appears to correspond to unit 266 of measured section number 2 of Kuenzi (1966, p. 221). Upper portion of Sixille Creek Formation.

Unit

Sandstone, tuffaceous, feldspathic; light gray; medium grained moderately sorted, with rounded grains; medium hard, compact (weathers soft and friable); ledge former; tabular uneven; internally very thin bedded, with graded trough cross-bedding. Contains up to $70 \%$ glass fragments. Sample 202-1 ........22

\section{LOCALITY 203. JEFFERSON RIVER}

$\mathrm{SE}_{\frac{1}{4}} \mathrm{SW}^{\frac{1}{4} \mathrm{NW}} \frac{\mathrm{L}}{4}$ sec. 28, T. 1 N., R. 4 W.; Madison County; cliff overlooking river at the west end of Parrot Bench. Unit 2 described below appears to correspond to unit 169 of measured section number I of Kuenzi (1966, p. 200). Bone Basin Member of the Renova Formation.

$\frac{\text { Unit }}{2 .}$

Estimated andstone, feldspathic; pale olive; coarse grained, well sorted very hard, compact; cliff former; calcareous cemented; tabular even; internal massive bedding. Lower contact
LOCALITY 204. (continued)

$\frac{\text { Unit }}{1}$

Claystone; grayish orange pink (weathers to medium brown); medium hard, compact (weathers to soft, loose); slope former tabular even; internal massive bedding. Trace of organic

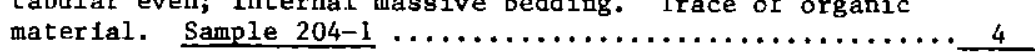

Total est1mated th1ckness $\ldots \ldots \ldots \ldots \ldots \ldots \ldots \ldots \ldots \ldots \ldots, 5$

\section{LOCALITY 205. PALISADE CLIFFS SOUTH}

$\mathrm{NW}_{2} \mathrm{SE}_{4} \mathrm{NW} \frac{1}{4}$ sec. 22, T. 2 N., R. 5 W.; Jefferson County; Mapped as Dunbar Creek Member of Renova Formation by Kuenzi and Fields (1971, Fig. 3). Strike $1^{\circ}$; dip $17^{\circ}$ to east.

$\frac{\text { Unit }}{3 \text {. }}$

Estimated thick. (ft)

2. Conglomerate, granite; yellowish gray (weathers to yellowish gray with grayish orange streaks); with rounded pebble clasts, in a matrix of poorly sorted, very coarse grained, arkosic sandstone; hard, compact (weathers to medium hard, compact) ledge former; strongly iron-stalned; lenticular bed; internally medium bedded with graded planar cross-bedding. Lower contact sharp, irregular. Minor biotite and some smokey quartz.

Lateral extent approximately 150 feet. Sample 205-2 ...... 10

1. Siltstone, sandy; yellowish gray (weathers to light greenish gray); medium hard, compact (weathers to soft, loose); slope former; calcareous cemented; tabular even; internal parallel even, thin bedding. Trace carbonaceous material. Sample even, thin bedding. Trace carbonaceous material. Sample

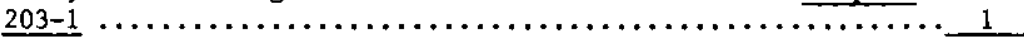

Total estimated thickness

\section{LOCALITY 204. PALISADE CLIFFS}

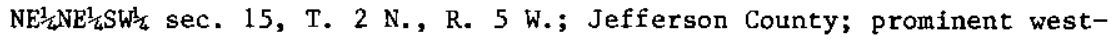
facing cliffs. Units 1 and 2 described below correspond to units 57 and 58 , respectively, of measured section number 9 of Kuenzi (1966, p. 277278). Sixmile Creek Formation.

stimated

Conglomerate, sandy; pale yellowish brown; with subrounded cobbles of volcanic rocks (70\%), and granite $(30 \%)$, in a matrix of poorly sorted, coarse grained, arkosic sandstone; medium hard, friable (weathers to soft, loose); slope former; tabular even; internal massive bedding. Lower contact sharp, regular. Minor biotite. Sample 204-2 $\ldots \ldots \ldots \ldots \ldots \ldots \ldots$. 1
- Siltstone, sandy; light olive gray; hard compact (weathers to soft, loose); slope former; iron-stained (primarily along contact); Internal thick parailel even bedding. Minor

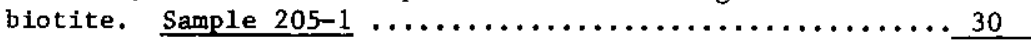

Total estimated thickness

\section{LOCALITY 206. LITTLE PIPESTONE}

SW $\frac{1}{4} \mathrm{NE}^{\frac{1}{4}} \mathrm{SW}^{\frac{1}{4}}$ sec. 9 T. 1 N., R. 5 W.; Jefferson County; stream cut on south side of creek along old highway 10. Units described below are within measured section number 5 of Kuenzi (1966, p. 267-268). Climbing Arrow Member of the Renova Formation.

$\frac{\text { Unit }}{3 .}$

stimated

tomerate, sandy; yellowish gray; with rounded cobbles of metamorphic rocks $(80 \%)$ and granite $(20 \%)$, in a matrix of poorly sorted, very coarse grained, feldspathic sandstone; hard, compact (weathers to medium hard, compact); ledge former; calcareous cemented; iron-stained; tabular uneven; internally thin bedded with graded planar cross-bedding. Lower contact sharp, irregular. Subordinate heavy minerals concentrated in bands parallel to bedding (blotite, magnetite,

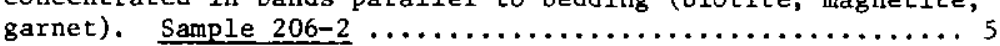


LOCALITY 206. (continued)

$\frac{\text { Unit }}{2 .}$ Siltstone, sandy; light olive; medium hard, compact; slope former; impermeable; tabular uneven; thin, parallel even bedding. Lower contact sharp, irregular. Sample 206-1 ... 5

1. Conglomerate (see description unit 3 ) $\ldots \ldots \ldots \ldots \ldots \ldots \ldots \ldots$

Total estimated thickness 13

\section{LOCALITY 207. LITTLE PIPESTONE EAST}

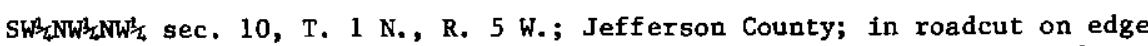
of bench south of Little Pipestone Creek. Mapped as Quaternary undifferentiated (includes some late Tertiary) by Kuenz1 and Fields (1971, Fig. $3)$. Beds approximately horizontal.

$\frac{\text { Unit }}{1 .}$

Estimated

onglomerate, metamorphic; medium orange gray; with rounded cobbles of metamorphic rocks $(90 \%)$, and grantte (10\%), in a matrix of poorly sorted, very coarse grained, feldspathic sand; soft, friable; slope former; permeable; iron-stalned; lenticular bed; internally medium bedded with graded parallel uneven bedding. Trace of carbonaceous material; minor heavy

irregular medium thick beds of conglomerate and sandstone.

Sample $207-1$.................................. 10

\section{LOCALITY 208. SAND CREEK}

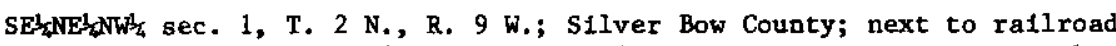
tracks west of highway 91 . Mapped as P11ocene-Miocene intermontane basin deposits by Smedes (1967).

Estimated

$\frac{\text { Unit }}{1 .}$ thick. (ft)

nglomerate, granite; yellowish gray (weathers to yellowish gray with grayish orange streaks); with rounded pebbles in a matrix pf poorly sorted, very coarse grained, feldspathic sand; soft, friable (weathers to soft, loose); slope former; iron-stained; lenticular bed; internally medium bedded with graded trough cross-bedding. Minor biotite. Sample 208-1.. 15

\section{LOCALITY 209. DIVIDE}

SW/ $\mathrm{SWS}_{4} \mathrm{NE}_{4}^{\frac{1}{4}}$ sec. 17, T. 1 S., R. 9 W.; Silver Bow County; in gravel pit east side of highway 91 . Mapped as Plfocene-Miocene intermontane basin deposits by Smedes (1967).

LOCALITY 209. (continued)

$\frac{\text { Unit }}{1 .}$ Conglomerate, well sorted, quartzite; light olive gray; with

Estimated rounded cobbles, in a matrix of poorly sorted, very coarse grained, feldspathic sand; soft, friable (weathers to soft, loose); slope former; permeable; iron-stalned; lenticular bed; internally medium bedded with graded trough crossbed; internally medium bedded with graded trough cross-
bedding. Sample $209-1 \ldots \ldots \ldots \ldots \ldots \ldots \ldots \ldots \ldots \ldots \ldots \ldots \ldots \ldots \ldots \ldots \ldots$

\section{LOCALITY 210. LIME GULCH}

$\mathrm{SE}_{\frac{1}{4} \mathrm{NE}^{\frac{1}{4}} \mathrm{SE} \frac{1}{4}}$ sec. 33, T. 1 N., R. 9 W.; Silver Bow County; along east side of highway 91. Mapped as P1focene-Miocene intermontane basin deposits by Smedes (1967). Average strike $45^{\circ}$; dip $9^{\circ}$ to east.

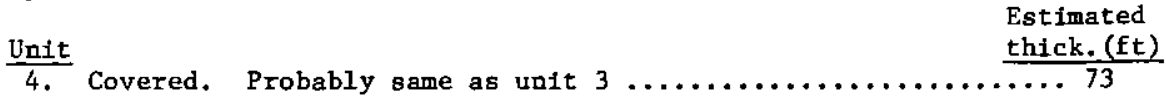

3. Conglomerate $(30 \%)$, limestone; very pale orange (weathers to yellowlsh gray); with subrounded cobbles of limestone (50\%), quartzite $(40 \%)$, and granite $(10 \%)$, in a matrix of poorly sorted, very coarse grained sandstone; hard, compact (weathers to medium hard, compact); cliff former; calcareous (weathers to medium hard, compact); cliff former; calcareous
cemented; lenticular bed; internal massive bedding. Lower contact sharp irregular. Trace heavy minerals. Sample

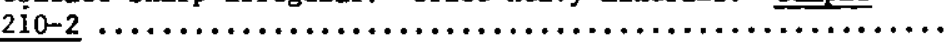
Siltstone (70\%), sandy; plnkish gray; poorly sorted, with subrounded grains; medium hard, compact (weathers to soft, friable); slope former; calcareous cemented; lenticular bed; internally thick bedded. Lower contact sharp irregular. Trace heavy minerals. Sample 210-1 ....................

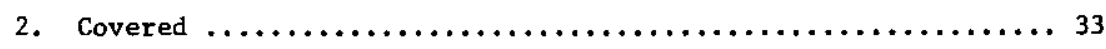

1. Conglomerate (20\%); (see description sample 210-2)........... Siltstone (80\%), sandy; (see description sample 210-1) .......

Total measured thickness

\section{LOCALITY 211. TWIN BRIDGES}

SE as Tertiary-Quaternary gravels and silts by Petkewich $(1972, \mathrm{P} 1.1)$

1. Conglomerate, well sorted, metamorphic; light gray with grayish orange streaks; with rounded cobbles of quartzite (80\%) and gneissic rocks (20\%), In a matrix of poorly sorted, coarse grained, feldspathic sand; soft, compact; slope former; permeable; iron-stained and black staining on clasts; lenticular bed; 1nternal masaive beds. Subordinate heavy minerals (garnet, magnetite and hastingsite). Contains minor sand lenses. Sample $211-1 \ldots \ldots \ldots \ldots \ldots \ldots \ldots \ldots \ldots \ldots \ldots 25$ 


\section{LOCALITY 212. WATERLOO}

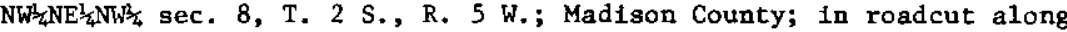
Riverside Drive. Unit described below is within 50 foot thick permeable fanglomerate bench deposits. Mapped as Tertiary-Quaternary gravels and silts by Petkewich (1972, P1. 1). Beds approximately horizontal.

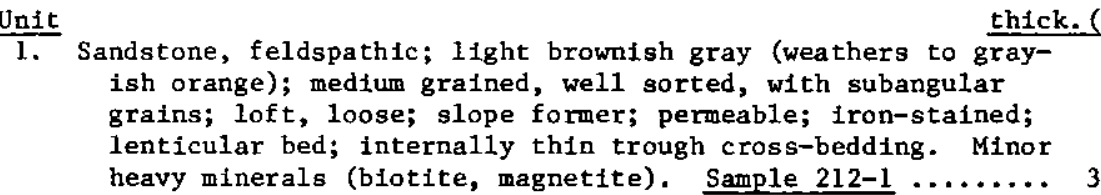

\section{LOCALITY 213. CURRANT CREEK}

$\mathrm{NE}_{2} \frac{1}{2} \mathrm{NW}_{3} \mathrm{NE}_{2} \frac{1}{4} \mathrm{sec} .2$, T. 3 S., R. 6 W.; Madison County; in pit on east of road. Unit described below overlain by 25 feet of fanglomerate bench deposits, and mapped as Tertiary-Quaternary gravels and silts by Petkewich (1972, P1, 1).

Unit Estimated

I. Siltstone, sandy; yellowish gray; soft, friable (weathers to soft, loose); slope former; permeable; tabular even; internal massive bedding. Trace of heavy minerals (magnetite). Sample 213-1 .

\section{LOCALITY 214. CALIFORNIA CREEK}

SW $\frac{1}{4} \mathrm{NE}_{1}^{\frac{1}{4}} \mathrm{SW}_{\frac{1}{4}}$ sec. 35, T. 5 S., R. 4 W.; Madison County; south side of quaking Aspen Creek valley. Mapped as late Tertiary-Quaternary conglomerate by Petkewich (1972, P1. 1). Strike $15^{\circ}$; dip $12^{\circ}$ to east.

thick. ( $f t$ )

1. Conglomerate, metamorphic; light gray; with subrounded cobbles of gniessic rocks, in a matrix of poorly sorted, subrounded, very coarse grained, feldspathic calcareous sandstone; hard, compact; ledge former; abundant calcareous cement; tabular even; internal thick, parallel even bedding. Sample 214-1. 30 Water sample taken from spring flowing from this unit. Water sample take
Sample $214-2$.

\section{LOCALITY 215. TAYLOR CEMETARY}

$\mathrm{NW}_{4} \mathrm{SW}_{4} \mathrm{NE}_{\frac{1}{4}}$ sec. 22, T. 6 S., R. 4 W.; Madison County; along county road. Mapped as basalt pebble conglomerate member of the Stxmile Creek Formation by Petkewich (1972, P1. 1).
LOCALITY 215. (continued)

Unit

stimated

1. Conglomerate, volcanic; light gray with medium gray streaks; with subrounded cobbles of volcantc rocks $(80 \%)$ and gnetssic rocks (20\%) in a matrix of poorly sorted, very coarse grained, sand; soft, loose; ledge former; tabular even; grained, sand; soft, loose; ledge former; tabular even;
internally very thick, parallel uneven bedded. Minor heavy minerals. Contains minor discontinuous silt beds. Sample

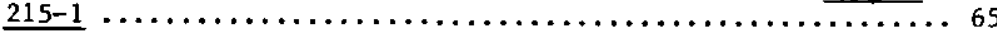

\section{LOCALITY 216. ROCHESTER CREEK}

$\mathrm{SE}_{\frac{1}{4}} \mathrm{SW}_{\frac{1}{4}} \mathrm{NE}_{\frac{1}{4}}^{\frac{1}{4}}$ sec. I5, T. 3 S., R. 7 W.; Madison County; on prominent cliff up creek. Unit has limited extent (about $1 / 2$ mile) and caps ridge underlain by Precambrian rocks. Mapped as Sixmile Creek Formation by Hoffman (1972, P1. 1).

Unit

Estimated

1. Conglomerate, metamorphic; yellowish gray (weathers to light olive gray); with subrounded cobbles of gneissic rocks, in a matrix of poorly sorted, very coarse grained feldspathic sandstone; hard, compact (weathers to medium hard, compact) cliff former; calcareous cemented; tabular even; internally cliff former; calcareous cemented; tabular even; internally Minor heavy minerals. Contains a few thin fine grained beds. Sample 216-1 ............................... 50

\section{LOCALITY 217. RATTLESNAKE BLUFF}

$\mathrm{NE}_{\frac{1}{4}} \mathrm{SW}_{4} / \mathrm{SW}_{4}^{2} \mathrm{sec} .7, \mathrm{~T} .5 \mathrm{~S}$, R. 5 W.; Madison County; on west side of canyon. Units described below are within measured section number 8 of Petkewich (1972, p. 334-336). Units 6, 7, 8 below correspond to Petkewich's units $24,25,26$, respectively, of the quartzite pebble conglomerate member of the Stxmile Creek Formation; units 1 thru 5 below correspond to Petkewich's units 1 thru 23 of the undifferentiated Sixmile Creek Formation. Strike $20^{\circ}$; dip $15^{\circ}$ to west.

$\frac{\text { Unit }}{8 .}$ Conglomerate (see description unit 6$) \ldots \ldots \ldots \ldots \ldots \ldots \ldots \ldots . .14 .2$

Measured

7. Sandstone, calcareous (see description unit 1) .......... 24.4

6. Conglomerate, metamorphic; yellowish gray; with rounded cobbles of quartzite $(80 \%)$ and gnelssic rocks $(20 \%)$, in a matrix of poorly sorted, very coarse grained, feldspathic calcareous sandstone; hard, compact; cliff former; abundant calcareous cement; tabular even; internal massive bedding. Lower contact sharp, regular. Minor heavy minerals in matrix. Sample

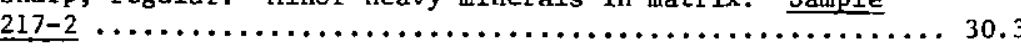

5. Sandstone, calcareous (see description unit 1) ............113.0 
3. Sandstone, calcareous (see description unit 1)

2. Siltstone, tuffaceous

1. Sandstone, calcareous; light gray; very fine grained, poorly sorted, with rounded grains; hard, compact; slope former; abundant calcareous cement; tabular even; internal parallel even, thick bedding. Less calcareous; with minor glassy

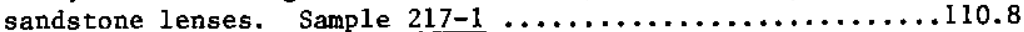

Total measured thickness

\section{LOCALITX 218. BENCH ROAD}

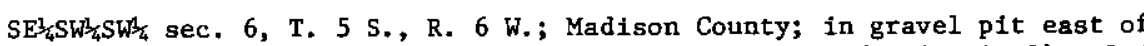
road. Mapped as Sixmile Creek Formation by Petkewich (1972, P1. I). Beds approximately horizontal.

$\frac{\text { Unit }}{4}$

Estimated thick. $(f t)$

3. Sandstone, arkostc; 1ight olive gray; medium grained, poorly sorted; soft, friable; slope former; tron-stained; lenticular channel; internal massive bedding. Lower contact sharp, regular. Subordinate blotite, with black coating on some gratns. Contains scattered rounded pebbles of quartzite and volcanic rocks. Lateral extent about 20 feet. Sample 218-2. 5

2. Siltstone, clayey; yellowish gray; moderately sorted; hard, compact; slope former; iron-stained; tabular even; internal parallel even, thin bedding. Lower contact sharp, irregular. Trace of heavy minerals. Sample 218-1 .............. 5

1. Sandstone $\ldots \ldots \ldots \ldots \ldots \ldots \ldots \ldots \ldots \ldots \ldots \ldots \ldots \ldots \ldots \ldots \ldots, 7$

Total estimated thickness

\section{LOCALITY 219. BEAVERHEAD ROCK}

NW $\frac{1}{4} \mathrm{NWF}_{\frac{1}{4}} \mathrm{NE}_{\frac{1}{4}}$ sec. 27, T. 5 S., R. 7 W.; Madison County; in gravel pit east of highway 41. Mapped as Climbing Arrow member of Renova Formation by Petkewich (1972, P1. 1), but due to proximity of younger sediments the placement of this unit within the formation is uncerta1n. Beds approxtmately horizontal.

\section{LOCALITY 219. (continued)}

Unit

1. Sandstone, arkosic; grayish orange; medium grained, well sorted, with rounded grains; soft, friable; slope former; strongly iron-stained; lenticular bed; internally thick bedded with trough cross-bedding. Lateral extent about 10 feet. Sample

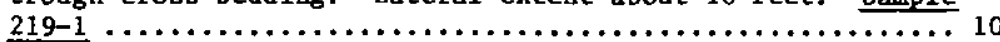

\section{LOCALITY 220. MCKINNEY DITCH}

$\mathrm{SW}_{\frac{1}{4}} \mathrm{SW}_{\frac{1}{4}} \mathrm{SE}_{\frac{1}{4}}^{\frac{1}{4}}$ sec. 26, T. 4 S., R. 7 W.; Madison County; in gravel pit. Mapped as Sixmile Creek Formation by Hoffman (1972, P1. 1)

Unit

Estimated thick. (ft)

1. Conglomerate, metamorphic; yellowish gray; with rounded, cobbles of quartzite $(80 \%)$ and gneissic rocks $(20 \%)$, in a matrix of moderately sorted, medium grained, arkosic sand; soft, friable; slope former; tabular even; Internal massive bedding. Minor petrified wood fragments (yellow staining); grains have black ofly coating; minor heavy minerals. Sample 220-1. 6

Total estimated thickness

\section{LOCALITY 221. BARTON CREEK}

$\mathrm{SE}_{\frac{1}{4}} \mathrm{SWH}_{4} \mathrm{SE}_{\frac{1}{4}}$ sec. 16, T. 7 S., R. 4 W.; Madison County; on north side of creek. Unit described below appears to correspond to unit 13 of measured section number 4 of Dorr and wheeler (1964, p. 317-319). This unit is in the upper portion of the Madison Valley equivalent (Dorr and wheeler, 1964, p. 317-318).

Unit

Estimated thick. (ft)

Conglomerate, metamorphic; light gray (weathers to light olive gray); with subrounded pebbles of quartzite (50\%) and gneissic rocks (50\%), In a matrix of poorly sorted, medium grained, tuffaceous sandstone; hard, compact; cliff former; tabular even; internal parallel even, medium bedding. Trace of silica replaced bone fragments. Sample 221-1 ........... 15

\section{LOCALITY 222. SPRING BROOK}

$\mathrm{SE}_{4}^{1} \mathrm{SEE}_{4}^{1} \mathrm{NW} / 4$ sec. 17, T. 9 S., R. 5 W.; Madison County; on hill sW side of brook. Untt described below is within the Madison Valley equivalent based on 1ithologic descriptions and geologic mapping done immediately to the north by Dorr and Wheeler (1964). 
1. Sandstone, conglomeratic; grayish yellow; coarse grained; poorly sorted; with subrounded pebbles of metamorph1c rocks (60\%), and tuff/siltstone (40\%); hard, compact; cliff former; 1ro stained; tabular even; internal massive bedding. Unit is altered due to close proximity to Tertiary volcanics.

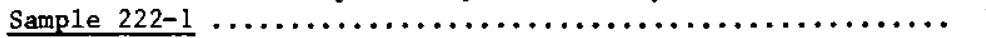

\section{LOCALITY 223. LEDFORD CREEK}

$\mathrm{SE}^{1} \mathrm{LSW} / \mathrm{NW} / \mathrm{s}$ sec. 20, T. 9 S., R. 4 W.; Madison County; on road between Robb Creek and Ledford Creek. Units described below are within the Madison Valley equivalent based on lithologic descriptions and geologic mapping nearby by Dorr and Wheeler (1964).

Estimated

2. Sandstone; medium grained; calcareous cemented thick. (ft)

1. Conglomerate, metamorphic; light gray; with rounded cobbles of quartzite (50\%) and gneissic rocks $(50 \%)$, in a matrix of moderately sorted, medium grained, sand; soft, loose; slope former; calcareous cemented; permeable; lenticular channel internal massive bedding. Lateral extent about 100 feet.

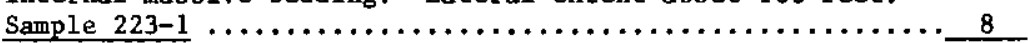

Total estimated thickness 10

\section{LOCALITY 224. FRYING PAN BASIN}

$\mathrm{SW}^{1} \mathrm{SEE}_{4}^{1} \mathrm{NE}^{\frac{1}{4}} \mathrm{sec}$. 20, T. 6 S., R. 9 W.; Beaverhead County; on cliff in the northeast corner of basin. Mapped as Tertiary sediments undifferentiated by Ross and others (1955).

$\frac{\text { Unit }}{1 .}$

Est1mated

Itstone, tuffaceous; light gray; medium grained, well sorted; medium hard, compact; cliff former; tabular uneven; internal massive bedding. Minor carbonaceous material (wood fragment composed of fusinite); trace of pyrite and calcite; (sample 224-2 taken of yellowish mineral (montmorillonite). Sample

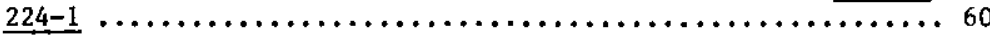

\section{LOCALITY 225. SAGE CREEK}

NE $\frac{1}{4} \mathrm{SW}_{\frac{1}{2} \mathrm{NE}}^{\frac{1}{2}} \mathrm{sec}$. 33, T. 12 S., R. 6 W.; Beaverhead County; in draw. Mapped as Sage Creek Formation by Scholten and others (1955, P1. 1). Conglomerate is within a 100-foot section of fine silty material.

Claystone, sandy (see unft 1)
Estimated thick. (ft)
2. Conglomerate, sandy; yellowish gray; with rounded cobbles of volcanic rocks $(40 \%)$, metamorphic rocks $(30 \%)$, and sedimentary rocks $(20 \%)$, in a matrix of moderately sorted, medium grained sandstone; hard, compact (weathers to medtum hard, compact); cliff former; calcareous cemented tabular even; internal parallel uneven, medium bedding. tower contact gradational. Trace of biotite. Sample 225-2. 8

1. Claystone, sandy; yellowish gray; fine grained, poorly sorted; hard, compact (weathers to medium hard, compact); slope former; tabular even; internal massive bedding. Sample

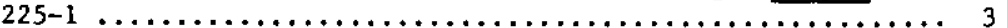

Total estimated thtckness

\section{LOCALITY 226. BIG SPRING GULCH}

$\mathrm{NE}_{4}^{1} \mathrm{NW}_{4} \mathrm{SW} / \mathrm{s}$ sec. 9, T. 12 S., R. 8 W.; Beaverhead County; water sample taken from spring on topographic map. Sample 226-1.

\section{LOCALITY 227. LITTLE SAGE CREEK}

$\mathrm{SE}_{\frac{1}{4}} \mathrm{NW}_{4} \mathrm{SW}_{\frac{1}{4}}$ sec. 28, T. $11 \mathrm{~S} .$, R. 7 W.; Beaverhead County; on northwest side of road. Mapped as Blacktail Deer Creek Formation by Scholten and others (1955, Pl. 1). $315^{\circ}$; d1p $7^{\circ}$ to west.

Conglomerate, volcanic; 1ight brownish gray; with subrounded cobbles of volcanic rocks $(70 \%)$ and quart 21 te $(30 \%)$, in a matrix of moderately sorted, medium grained sandstone; hard, compact; cliff former; calcareous cemented; tabular even; internal parallel uneven; medium bedded. Lower contact sharp, regular. Trace carbonaceous material. Possible channel.... 20

2. Sandstone, tuffaceous; yellowish gray; medium grained, moderately sorted, with rounded grains; hard, compact (weather to medium hard, compact); cliff former; slightly calcareous cemented; tron-stained; tabular even; internally medium bedded with planar cross-bedding. Lower contact sharp, regular. Trace carbonaceous material. Sample 227-4 …................ 67.5

1. Sandstone $(10 \%)$, conglomerat $1 c$, tuffaceous; very pale orange; medium grained, poorly sorted; with subrounded pebbles of volcanic rocks ( $80 \%)$ and quartzlte $(20 \%)$; hard, compact (weathers to medium hard, compact); cliff former; calcareous cemented; tabular even; internal irregularly thick bedding. Lower contact irregular. Sample taken near upper contact.

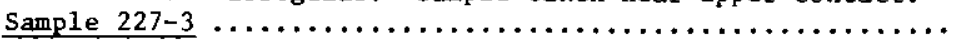


LOCALITY 227. (continued)

Unit

Conglomerate (30\%), well sorted, volcanic; light gray; with

rounded cobbles of volcanic rocks $(60 \%)$ and quartzite $(40 \%)$,

in a matrix of poorly sorted, very coarse grained sandstone; hard, compact; cliff former; calcareous cemented; lenticular channel; internally medium bedded with trough cross-bedding. Lower contact sharp, 1rregular. Sample 227-2 ............

Sandstone $(60 \%)$, silty, tuffaceous; pale yellowish brown; very fine gralned, well sorted; hard, compact. Bedding character-

istics same as in sample 227-3. Sample 227-1 ..........153.5

Total measured thickness

\section{LOCALITY 228. BOX SPRINGS}

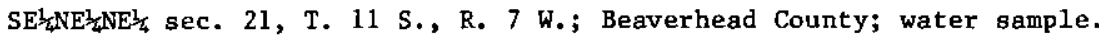
Sample 228-1.

\section{LOCALITY 229. BLACKTAIL DEER CREEK}

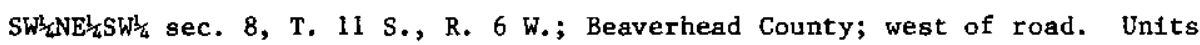
described below are within the type section of the Blacktail Deer Creek Formation as measured by Hibbard and Keenmon (1950, p. 195-198), and mapped by Scholten and others (1955, P1. 1). Samples are representative of the sand, clay interbeds with the section Strike $170^{\circ}$; dip $5^{\circ}$ to west.

$\frac{\text { Unit }}{2}$ Sandstone, thick. (ft)

andstone, conglomeratic, feldspathic; yellowish gray; coarse grained, poorly sorted, with subrounded grains; with sub-
rounded pebbles of quartzite $(60 \%)$ and volcanics $(40 \%)$; hard, compact; ledge former; slightly calcareous cemented; ironstained; tabular even; internally parallel even medium bedded. Lower contact sharp, regular. Sample 229-2 ........... 2

1. Siltstone, clayey; pale greenish yellow; moderately sorted; hard, compact; slope former; Iron-stained; tabular even; internally parallel even thick bedded. Sample 229-1 …..... 8

Total estimated thickness $\ldots \ldots \ldots \ldots \ldots \ldots \ldots \ldots \ldots \ldots \ldots$

\section{LOCALITY 230. BURNS MOUNTAIN}

$\mathrm{SE}_{\frac{1}{4}} \mathrm{SE}_{\frac{1}{4}} \mathrm{NW} \frac{1}{4} \mathrm{sec} .3$, T. 8 S., R. 10 W.; Beaverhead County; along creek. Mapped as later tuffs (Oligocene) by Lowel1 (1952).

$\begin{array}{ll}\text { Unit } & \text { Estimated } \\ \text { thick. (ft) }\end{array}$

Sandstone, tuffaceous; 1ight greenish gray; medium grained, well sorted, with subangular grains; hard, compact; cliff former; tron-stained; tabular uneven; internal massive bedding. Abrasion of grains and some cross-bedding indicates some reworking. Sample $230-1 \ldots \ldots \ldots \ldots \ldots \ldots \ldots \ldots \ldots \ldots$

\section{LOCALITY 231. FRYING PAN GULCH}

$\mathrm{NE}_{4} \mathrm{SE}_{4} \mathrm{SW}_{4}$ sec. 31, T. 6 S., R. 9 W.; Beaverhead County; along dirt road to Christensen Ranch. Mapped as Oligocene rhyolite tuff by Myers (1952, P1. 1).

Undt

stimated thick. ( $f t)$

Tuff; 1ight gray; medium grained, moderately sorted; hard, compact (weathers to medium hard, compact); slope former: compact (weathers to medium hard, compact); slope former; heavy minerals in some beds (primarily). Contains $80 \%$ glassy volcanic rock fragments. Sample 231-1 $\ldots \ldots \ldots \ldots$.

\section{LOCALITY 232. CROORED CREEK}

$\mathrm{NW}_{\frac{1}{4}} \mathrm{NW}_{4} \mathrm{NEE}_{\frac{1}{4}} \mathrm{sec}, 8$, T. $11 \mathrm{~s} .$, R. 8 W.; Beaverhead County; on the north side of road. Mapped within the Cook Ranch Volcanics of Scholten and others (1955, P1. 1), but the lithology indicates that they are probably in the Cook Ranch Formation, which is mapped just to the south across Sage Creek. Strike $265^{\circ}$; dip $18^{\circ}$ to south.

\section{Estimated} thick. ( $f t)$

3. Sandstone, conglomeratic, feldspathic; Iight yellowish gray; very coarse grained, poorly sorted; with subrounded pebbles of volcanic rocks (45\%), metamorphic rocks (45\%), and reworked claystone (10\%); hard, compact; ledge former; ironstained; tabular even; internal massive bedding. Lower contact sharp, regular. Sample $232-3 \ldots \ldots \ldots \ldots \ldots \ldots \ldots \ldots, 2$

2. Claystone, sandy; yellowish gray; medium hard, compact; slope former; tron-stained; tabulax even; internal massive bedding. Lower contact gradational. Sample $232-2 \ldots \ldots \ldots \ldots \ldots \ldots, 4$

1. Sandstone; yellowish gray; coarse grained, moderately sorted; medium hard, loose (weathers to soft, loose); slope former; Iron-stained; tabular even; internally parallel even, medium

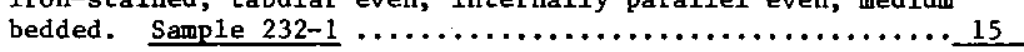

Total estimated thickness $\ldots \ldots \ldots \ldots \ldots \ldots \ldots \ldots \ldots \ldots \ldots \ldots, 21$

\section{LOCALITY 233. HORSE PRAIRIE CREER}

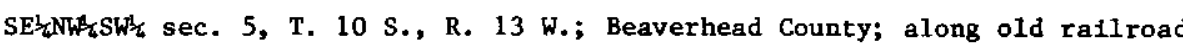
grade. Mapped as Tertiary sediments undifferentiated by Ross and others (1955). Minor faulting in section. Strike $10^{\circ}$; dip $30^{\circ}$ to east. Thickness of sub-units within unit 2 below become thinner in basal portions.

$\frac{\text { Unit }}{5}$

Measured

$\frac{\text { nit }}{5 .}$ Siltstone, clayey (see unit 2 description) ................. thick.

4. Sandstone, conglomeratic, granitic (see unit 2 description) ..141.1 
2. Sandstone (60\%), conglomeratic, granitic; moderate yellowish brown; with subrounded pebbles of granitic rocks, in a matrix of poorly sorted, coarse grained, arkosic sandstone; medium hard, friable; slope former; iron stained; tabular even, internal massive bedding. Lower contact sharp,

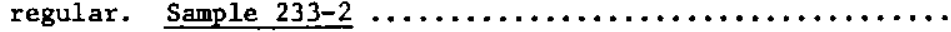
Siltstone (40\%), clayey; light olive gray; poorly sorted; medium hard, compact; slope former; tabular even; internal parallel uneven, medium bedding. Lower contact sharp, regular. Trace carbonaceous material. Scattered subangular pebbles of granitic rock $(80 \%)$ and volcanic rock $(20 \%)$ in

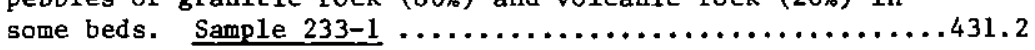

1. Siltstone, clayey (see unit 2 description) $\ldots \ldots \ldots \ldots \ldots \ldots, 58.6$

Total measured thickness $\ldots \ldots \ldots \ldots \ldots \ldots \ldots \ldots \ldots \ldots \ldots \ldots . \ldots \ldots 12.2$

\section{LOCALITY 234. KATE CREEK}

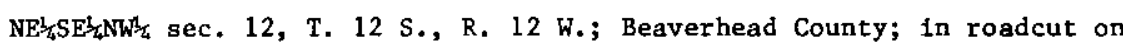
west side of road at Junction of Kate Creek and Medicine Lodge Creek.

1. Sandstone, conglomeratic, arkosic; yellowish gray, very coarse grafned, poorly sorted; with subrounded pebbles of granitic rock $(60 \%)$, quartzite $(30 \%)$, and siltstone $(10 \%)$; hard, compact; cliff former; iron-stained; tabular even; internal parallel even, medium bedding. Sample 236-1 $\ldots \ldots \ldots \ldots \ldots .5$

\section{LOCALITY 237. TIPPET PLACE}

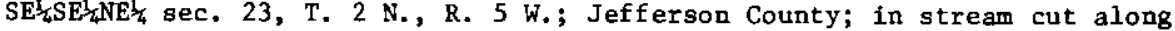
road about 20 feet from contact with Cretaceous volcanics. Mapped as

Sixmile Creek Formation by Kuenzi and Fields (1971, Fig. 3). Beds approximately horizontal.

Unit

Estimated

1.

Conglomerate, volcanic; dusky yellow; with subrounded pebbles of volcanic rocks $(95 \%)$ and granite $(5 \%)$, in a matrix of moderately sorted, coarse grained, granitic, arkosic sand; medium hard, friable (weathers to soft, loose); slope former: iron-stained (yellowish green to orange staining); lenticular channel; internally medium bedded with trough cross-bedding.

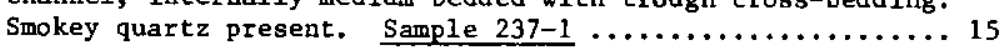

\section{LOCALITY 238. ANDERSON LEASE}

$\mathrm{NE}_{4}^{1} \mathrm{SW}_{4} \mathrm{NW} / 4$ sec. 17, T. 9 S., R. 5 W.; Madison County; prospect pit on lease. Unit described below is within the Madison Valley equivalent based on

lithologic descriptions and geologic mapping done immediately to the north by Dorr and Wheeler (1964). Strike $100^{\circ}$; dip $4^{\circ}$ to south.

onglomerate, well sorted, metamorphic; grayish orange; with rounded cobbles of metamorphic rocks $(60 \%)$ volcanic rocks $(30 \%)$, and granitic rocks $(10 \%)$, in a matrix of poorly sorted coarse gratned sandstone; hard, compact; cliff former calcareous cemented; iron-stained; tabular even; internal parallel even, thick bedding. Sample 234-1 $\ldots \ldots \ldots \ldots \ldots \ldots 12$

\section{LOCALITY 235. BACHELOR MOUNTAIN}

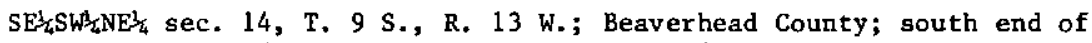
mountain. Mapped as Tertlary sediments undifferentiated by Ross and others (1955). Strike $85^{\circ}$; dip $22^{\circ}$ to south.

Estimated Unit thick. (ft)

1. Sandstone, feldspathic; yellowish gray; medium grained, well sorted; hard, compact; ledge former; Iron-stained; tabular even; internal massive bedding. Sample 235-1 .......... 20

\section{LOCALITY 236. COYOTE CREEK}

$\mathrm{NE}_{\frac{1}{4}} \mathrm{SE}_{\frac{1}{4}} \mathrm{SE}_{\frac{1}{4}}$ sec. 33, T. 9 S., R. 14 W.; Beaverhead County; up Horse Prairie Guard station road from Bloody Dick Creek turn off. Mapped as Tertiary sed1ments undifferentiated by Ross and others (1955).

coarse grained, poorly sorted; medium former; strongly iron-stained; tabular even; internal parallel uneven, medium bedding. Minor heavy minerals (primarily). Sample has abundant smokey quartz, and is

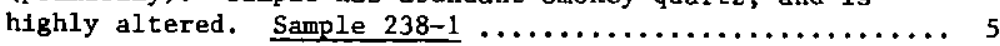

\section{LOCALITY 239. SWEETWATER ROAD}

$\mathrm{SW}_{\frac{1}{4}} \mathrm{SE}_{\frac{1}{4} \mathrm{SW}} \mathrm{s}$ sec. 34, T. 8 S., R. 5 W.; Madison County; on the north side of draw. Mapped as the Madison Valley equivalent by Dorr and Wheeler (1964, Fig. 1).

$\frac{\text { Unit }}{1}$

Estimated

1. Sandstone, clayey; pale greenish yellow; coarse gralned, thick. (ft) greenish yellow; coarse grained, poorly sorted; soft, friable; slope former; 1ron-stained; tabular uneven; internally parallel uneven, medium bedded. Trace of silica replaced wood. Contains gypsum. Sample 239-1 .....20 
$\mathrm{SE}_{\frac{1}{4}}^{\frac{1}{2}} \mathrm{SW}_{\frac{1}{4}} \mathrm{NE}_{\frac{1}{4}} \mathrm{sec} .12$, T. 8 S., R. 5 W.; Madison County; in cliffs along west side of Sweetwater Road west of Upper Ruby Cemetary. Units 1 and 2 described below correspond to units 2 and 3 , respectively, of measured section number 2 of Dorr and Wheeler $(1964, \mathrm{p}, 312-314)$. The units are in the lower portion of the Madison Valley equivalent (Dorr and Wheeler, 1964, p. 313).

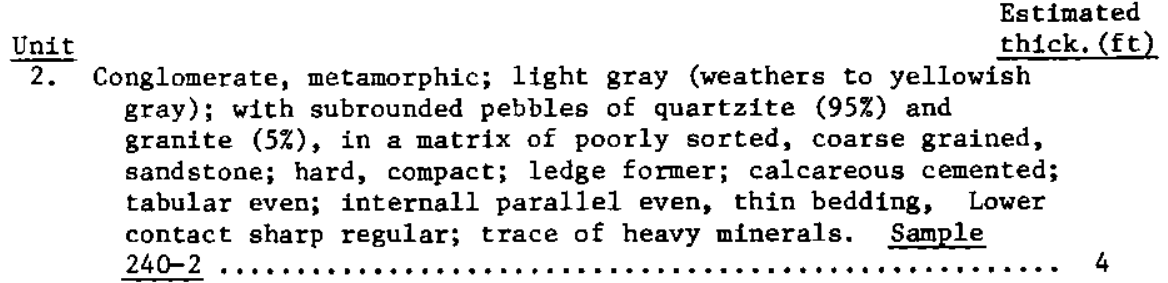

1. Siltstone; yellowish gray; medium hard, friable; cliff former; tabular even; internal massive bedding. Sample $240-1 \cdots \cdots 42$

Total estimated thickness 46

\section{LOCALITY 241. RUBY RIVER RESERVOIR}

SE $\frac{1}{4} \mathrm{SW}_{\frac{1}{4}} \mathrm{SW} \frac{1}{4}$ sec. 19, T. 7 S., R. 4 W.; Madison County; on hill along west side of reservolr. Mapped as "Red Conglomerate" by Dorr and Wheeler (1964, Figs. 1 and 2)

1. Conglomerate, limestone; well sorted; grayish orange (weathers to moderate reddish orange); with subrounded cobbles of limestone $(80 \%)$, and quartzite $(20 \%)$, in a matrix of poorly sorted, very coarse grained sandstone; very hard, compact (weathers to hard, compact); cliff former; calcareous cemented; impermeable; iron-stained; tabular uneven; internally

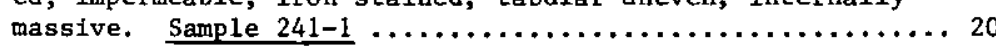

\section{LOCALITY 242. COTTONWOOD CREEK}

$\mathrm{SE}_{4} \mathrm{SW}_{\frac{1}{4}} \mathrm{SE}_{\frac{1}{4}}$ sec. 34, T. 7 S., R. $5 \mathrm{~W}$; Madison County; in roadcut along Cottonwood Creek road. Mapped as Passamari Formation by Dorr and Wheeler (1964, Fig. 1). Sandstones described below constitute a very minor portion of Passamari Formation.

$\frac{\text { Unit }}{3 .}$ Claystone (see description unit 1)

2. Sandstone; yellowish gray; medium grained, moderately sorted, with subrounded grains; medium hard, friable (weathers to soft, friable); slope former; iron-stained; lenticular bed; internally parallel even, thin bedding. Lower contact sharp, irregular. Minor carbonaceous material. Sample 242-2 .... 2
1. Claystone; pale olive; hard, compact; slope former; calcareous cemented; tabular even; internal massive bedding. Minor car-

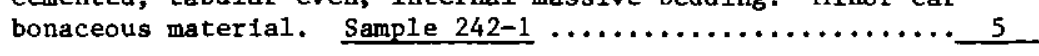

Total estimated thickness

\section{LOCALITY 243. COOK RANCH}

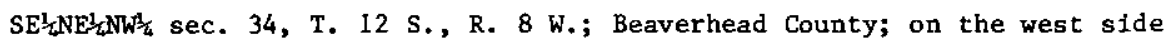
of Sage Creek Road. Cook Ranch and Sage Creek Formations of Scholten and others (1955, P1. 1), and proposed Sage Creek Formation of Hough (1955). Strike $165^{\circ}$; dip $13^{\circ}$ to west.

4. Conglomerate, well sorted, quartzite; 1ight gray; with rounded cobbles of quartzite $(60 \%)$ and volcanic rocks $(40 \%)$, in a toatrix of poorly sorted, very coarse grained sandstone; hard, compact; cliff former; iron-stained; tabular uneven; internal massive bedding. Lower contact sharp, Irregular. Sample

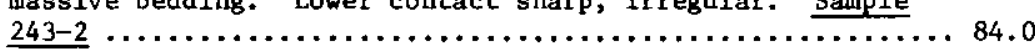

3. Siltstone; 1ight greenish gray; moderately sorted; hard, compact (weathers to medium hard, loose); slope former; calcareous cemented; tabular even; internal parallel even, thick beding. Lower contact sharp, regular. Differential cementation within unit forms resistant beds. Sample $243-1 \ldots \ldots .133 .0$

2. Sandstone; light gray; medium grained; hard, compact; ledge former; calcareous cemented; tabular even; internal parallel

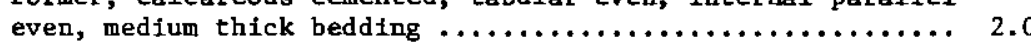

1. Siltstone; light greenish gray; moderately sorted; hard, compact (weathers to medium hard, loose); slope former; calcareous cemented; tabular even; internal parallel even, thick bedding. Differential cementation within unit forms resistant beds...147.3

Total measured thickness .366 .4

\section{LOCALITY 244. SAGE CREEK WEST}

$\mathrm{SE}_{2} \mathrm{SWW}_{2} \mathrm{SW} / \mathrm{s}$ sec. 33, T. 12 S., R. 8 W.; Beaverhead County; on north side of Sage Creek Road. Mapped as Sage Creek Formation by. Scholten and others (1955, P1. 1)

Sandstone, tuffaceous; yellowish gray; medium grained, moderate sorted; hard, compact (weathers medium hard, compact); cliff even, medium bedding. Minor biotite. Contains punice

fragments. Sample $244-1 \ldots \ldots \ldots \ldots \ldots \ldots \ldots \ldots \ldots \ldots \ldots 40$ 


\section{LOCALITY 245. ROCK CREEK}

$\mathrm{NW}_{4} \mathrm{NE}_{4} \mathrm{NWW}_{4}$ sec. 5, T. 14 S., R. 10 W.; Beaverhead County; in Rock Creek Canyon west of Muddy Creek. Mapped as "Muddy Creek" beds by Scholten and others $(1955, \mathrm{P1} .1)$. Unit lightly iron

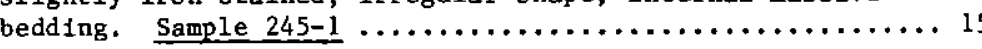

\section{LOCALITY 246. TRAIL HOLLOW}

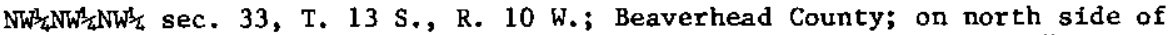
Muddy Creek road across from Trail Hollow. Mapped as "Muddy Creek" beds by Scholten and others $(1955, \mathrm{P} 1.1)$. Str1ke $141^{\circ}$; dip $16^{\circ}$ to NE. Approximately 100 feet of claystone and shale exposed; sample taken from basal portion.

$\frac{\text { Unit }}{3 \text {. }}$

Estimated

2. Shale, carbonaceous; moderate brown; medium hard, brittle (weathers to soft, brittle); slope former; tabular even; internal parallel even, laminar bedding. Abundant gypsum along some bedding planes. Sample 246-1 $\ldots \ldots \ldots \ldots \ldots \ldots \ldots \ldots$. 1

Total estimated thickness

\section{LOCALITY 247. BIG SHEEP CREEK}

NWh $\mathrm{SE}_{\frac{1}{2} \mathrm{SW}} \frac{1}{2}$ sec. 20 , T. 13 S., R. 9 W.; Beaverhead County; along west side of road at mouth of canyon. Mapped as Beaverhead Formation by Scholten and others $(1955, \mathrm{P} 1.1)$.

Unit

Estimated

1. Conglomerate; well sorted; 1imestone; moderate orange pink thick. (ft)

with subrounded cobbles of limestone $(60 \%)$ and quartzite $(40 \%)$ in a matrlx of poorly sorted, very coarse grained sandstone; very hard, compact; cliff former; calcareous cemented; impermeable; iron-stained; tabular even; internal massive

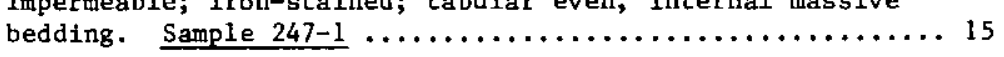

\section{LOCALITY 248. MEDICINE LODGE PEAK}

$\mathrm{NE}_{\frac{1}{4}}^{1} \mathrm{SE}_{\frac{1}{2} \mathrm{NE} \frac{1}{4}}$ sec. 14, T. 12 S., R. 12 W.; Beaverhead County; along west side of road. Lithologically similar to Medicine Lodge shales mapped by McGonigle (1965, P1. 1) to the north. Sample taken from tailings pile; unit not exposed at surface. Sample 248-1 is lignite, grayish black; medium hard, brittle; slope former, with minor gypsum.

\section{LOCALITY 249. KEYSTONE RESERVOIR}

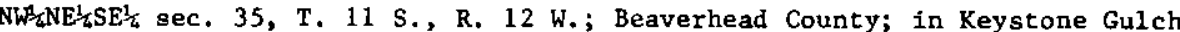
Mapped as Medicine Lodge Shales by M'Gonigle (1965, Pl. 1). Strike $150^{\circ}$; dip $26^{\circ}$ to east.

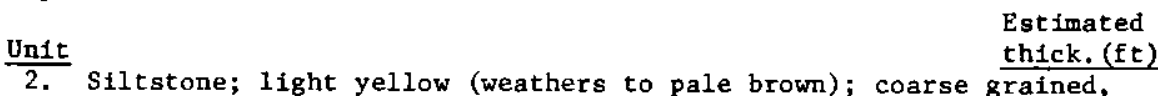
hard, compact; cliff former; iron-stained; tabular even; internal parallel even, very thin bedding. Lower contact sharp, regular. Minor carbonaceous material. Sample 249-2. 12

1. Ligntte; black (weathers to dark brown); medium hard, brittle; slope former; tabular even; internal parallel even; laminar bedding. Gypsum present along bedding plane. Sample 249-1.

Total estimated thickness $\ldots \ldots \ldots \ldots \ldots \ldots \ldots \ldots \ldots \ldots \ldots \ldots$

\section{LOCALITY 250. SHENON CREEK}

NWh $W_{1}^{1} \frac{1}{4} S_{1 / 4}^{\frac{1}{4}}$ sec. 18 , T. 10 S., R. 13 W.; Beaverhead County; sample taken from tailings of mine on east side of highway. Mapped as Tertiary sediments undifferentiated by Ross and others (1955) but close association with Tertiary volcanic rocks and lithology indicate volcanic origin.

Estimated

1. Tuff (?); light brown; fine grained; hard, compact; iron-stained; irregular shape; internal massive bedding. Extremely

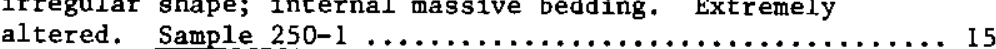

\section{LOCALITY 251. MUDDY CREEK}

$N^{3} \frac{1}{4} \mathrm{SW}_{\frac{1}{4} \mathrm{SE}} \frac{2}{2}$ sec. 3, T. 14 S., R. 10 W.; Beaverhead County; north side of creek. Mapped as Quaternary terrace gravels and alluvial fans by Scholten and others (1955, P1. 1) but 1ithologic similarities to the "Muddy Creek" beds Indicate that they should be considered "Muddy Creek" beds.

8. Sandstone; grayish yellow; medium grained, well sorted; medfum hard, compact (weathers to soft, friable); slope former; Iron-stained; tabular even; internal parallel even, medium bedding. Lower contact sharp, regular. Contains a few minor grave1 lenses. Sample $251-3 \ldots \ldots \ldots \ldots \ldots \ldots \ldots \ldots \ldots 2.2$

7. Thin bedded sequence of light gray, iron-stained sandstones light brown; carbonaceous siltstones; and purplish gray claystones and shales. Sandstones comprise bottom layers, claystones and shales form majority of upper portion $\ldots \ldots \ldots \ldots 221.2$

6. Sandstone; light gray; medium grained, well sorted; very hard, compact; ledge former; silica cemented; iron-stained; tabular even; internal parallel, thin bedding. Lower contact sharp, regular $\ldots \ldots \ldots \ldots \ldots \ldots \ldots \ldots \ldots \ldots \ldots \ldots \ldots \ldots \ldots \ldots \ldots \ldots \ldots \ldots \ldots \ldots, 3.5$ 
Unit $\begin{aligned} & \text { Measured } \\ & \text { thick. (ft) }\end{aligned}$

$\frac{\text { Unit }}{5 .}$

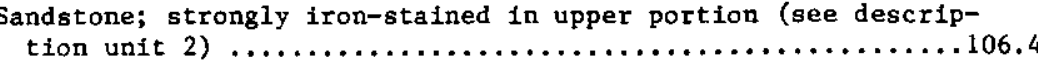

4. Conglomerate; (see description untt 2) ................ 3

3. Sandstone; light gray; fine grained, well sorted; medium hard, compact; slope former; slightly fron-stalned; tabular even; internal parallel even, medium bedding. Lower contact sharp,

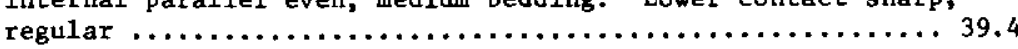

2. Conglomerate, sedimentary; pale yellowlsh orange (weathers to grayish orange); with subrounded cobbles of sandstones and siltstones $(80 \%)$, limestone $(10 \%)$, and quartzite $(10 \%)$, in a matrix of well sorted, medium grained sandstone; hard, compact; ledge former; calcareous cemented; iron-stained; tabular uneven; internal masoive bedding

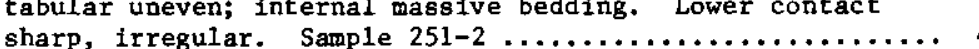

1. Siltstone, sandy; light gray; moderately sorted; medium hard, compact; slope former; calcareous cemented; iron-stained; tabular even; internal massive bedding. Sample 251-1 .....42.1

Total measured thickness

\section{LOCALITY 252. LIMA RESERVOIR}

SWla SWENW/4 sec. 32, T. 13 S., R. 6 W.; Beaverhead County; in cliff on the north side of Lima Dam. Mapped as Beaverhead Formation by Scholten and others $(1955, \mathrm{P1} .1)$.

Unit

1. Conglomerate; well sorted; pale red; with subrounded cobbles of limestone and quartzite in a matrix of poorly sorted, very coarse grained sandstone; very hard, compact; cliff former; calcareous cemented; impermeable; iron-stained; tabular even internal parallel even, very thick bedding. Sample 252-1 ..360

\section{LOCALITY 253. CEDAR CREEK}

SELNWRSWR sec, 2, T. 6 S., R. 1 W.; Madison County; on the northern tip of the bench located on the SW side of creek. Mapped as Quaternary and Tertiary sediments undifferentiated by Egbert (1967, P1. 1), but 1ithologic similarities to units mapped by Hadley (1969b) to the south indicate that the unit is lower Pleistocene in age.

Unit

Estimated

1. Sandstone, feldspathic; light gray; medium grained, well sorted; hard, compact; cliff former; calcareous cemented; tabular even; internally thin bedded with planar cross-bedding.

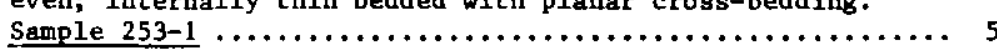

LOCALITY 254. SQUAW CREEK

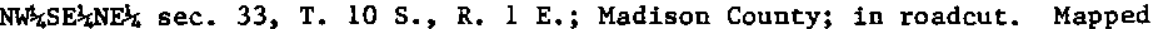
as Quaternary alluvium, pyroclastic rocks, landslides, glacial material and later Tertiary lake beds undifferentiated by Egbert (1967, P1. 1). Unit is closely associated with Tertiary volcanics. Un1t
1. Sandstone, tuffaceous; light gray; fine grained, moderately
sorted; soft, loose, slope former; tabular even; internal parallel uneven, medium bedding. Contains $90 \%$ glassy fragments. Beds folded. Sample 254-1 $\ldots \ldots \ldots \ldots \ldots \ldots \ldots \ldots, 30$

\section{LOCALITY 255. VARNEY}

$\mathrm{NW}_{4} \mathrm{NW}_{4} \mathrm{SW} \frac{1}{4}$ sec. 29, T. 7 S., R. I W.; Madison County; in stream bed. Mapped as lower P1lestocene cobble gravels by Hadley (1969b).

2. Conglomerate, well sorted; limestone; pale yellowish brown; w1th subrounded cobbles of Ifmestone (75\%) and quartz1te (25\%), in a matrix of poorly sorted, very coarse grained sandstone; hard, compact; ledge former; calcareous cemented; tabular even; internal msssive bedding. Lower contact sharp, regular. Trace carbonaceous material. Sample 255-2 ..............

1. Siltstone, sandy; pale yellow; poorly sorted; medium hard, compact (weathers to soft, loose); slope former; calcareous cemented; tabular even; internal massive bedding. Trace carbonaceous material. Scattered pebbles of quartzite. Sample $255-1, \ldots \ldots \ldots \ldots \ldots \ldots \ldots \ldots \ldots \ldots \ldots \ldots, 4$

Total estimated thickness $\ldots \ldots \ldots \ldots \ldots \ldots \ldots \ldots \ldots \ldots \ldots, 7$

\section{LOCALITY 256. SPRING CREEK DITCH}

NW $3 \mathrm{NEE}_{4}^{3} \mathrm{NW}$ sec. 20, T. 6 S., R. 1 W.; Madison County; in roadcut along county road on the west side of Madison River. Mapped as Quaternary and Tertiary sediments undifferentiated by Egbert (1967, P1, 1).

- Sandstone, conglomerat1c; yellowish gray; coarse grained, moderately sorted; with subrounded pebbles of volcanic rocks $(80 \%)$, quartzite $(10 \%)$, and claystone $(10 \%)$; very hard, compact; cliff former; calcareous cemented; tabular even; Internal parallel even, thick bedding. Sample 256-1 ......

\section{LOCALITY 257. BEAR CREEK}

$\mathrm{NE}_{4}^{\frac{1}{4} \mathrm{SW}_{4} \mathrm{~N} W \mathrm{l}_{4}}$ sec. 11, T. 6 S., R. 1 W.; Madison County; in gravel pit. Mapped as Quaternary and Tertiary sediments undifferentiated by Egbert (1967, P1. 1), but lithologic similarities to units mapped by Hadley (1969a, 1969b) to the south indicate that unit is lower Pleistocene in age. 
1. Conglomerate, well sorted, granite gneiss; medium gray; with rounded cobbles of granite gneiss (95\%), and sandstone $(5 \%)$, in a matrix of well sorted, medium grained sandstone; soft, loose; slope former; Iron-stalned; tabular even; internal parallel even, thick bedding. Some clasts have black coating of manganese oxide. Sample $257-1 \ldots \ldots \ldots \ldots 50$

\section{LOCALITY 258. NORTH MEADOW CREEK}

$\mathrm{NB}_{2} \mathrm{NW}_{2} \mathrm{SE}_{\frac{1}{4}}$ sec. 19, T. 4 S., R. 1 W.; Madison County; in gravel pit located on the east side of creek. Mapped as Quaternary and Tertiary sediments undifferentiated by Egbert (1967, P1. 1)

Untt

Estimated

1. Conglomerate, well sorted, granite gneiss; moderate brown thick. (ft) (weathers to graylsh orange); with rounded cobbles of granite gneiss, in a matrix of moderately sorted, medium grained sandstone; soft, loose; slope former; strongly iron-stained; tabular uneven; internal parallel even, thick bedding.

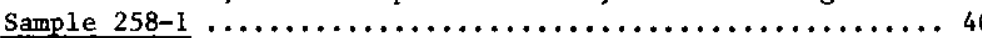

\section{LOCALITY 259. RIVERSIDE DRIVE}

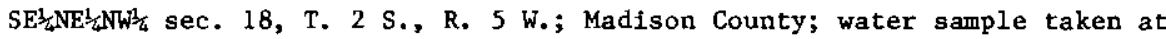
base of bench along Riverside Drive, from spring flowing out of unit mapped as Sixmile Creek Formation by Petkewich (1972, Pl. 1). Sample 259-1.

\section{LOCALITY 260. DRY BOULDER CREEK}

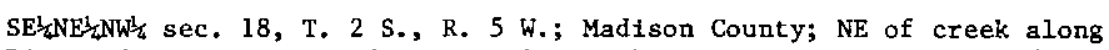
Riverside Drive. Mapped as Sixmile Creek Formation by Petkewich (1972, P1. 1). Strike $115^{\circ}$; dip $5^{\circ}$ to south.

Sandstone, tuffaceous; yellowish gray; medium grained, moderately sorted; medium hard, compact; slope former; tabular even; internally massive. Unit grades from $80 \%$ glass, $20 \%$ clay (decomposed glass) near bottom to $50 \%$ glass, $50 \%$ clay in upper portion. Sample $260-1 \ldots \ldots \ldots \ldots \ldots \ldots \ldots \ldots . \ldots$

\section{LOCALITY 261. STONE CREEK}

$\mathrm{NW}_{4} \mathrm{NWB}_{4} \mathrm{NE}_{\frac{1}{4}}$ sec. 13, T. 6 S., R. 8 W.; Beaverhead County; in roadcut along highway 41. Mapped as Tertiary sediments undifferentiated by Ross and highway 41 . Mapped as Tertiary sediments und
others (1955). Strike $175^{\circ}$; dip $1^{\circ}$ to west.

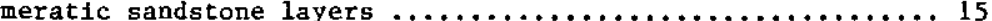

$\underline{\text { Unit }}$

2. Sandstone, conglomeratic; yellowish gray; medium grained, poorly sorted; with subrounded pebbles of metamorphic rock $(80 \%)$ and volcanic rock $(20 \%)$, very hard, compact; ledge former; calcareous cemented; tabular even; internal massive bedding. Lower contact sharp, regular. Sample 261-2 ..... 1

1. Sandstone, silty; pale yellowish brown; fine grained, poorly sorted; medlum hard, compact; cliff former; calcareous cemented; tabular even; internal massive bedding. Sample

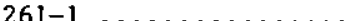

Total estimated thickness 5

\section{LOCALITY 262. EAST FORK}

SW $\frac{1}{4} S W \frac{1}{4} N W \frac{1}{4}$ sec. 6, T. 11 S., R. 5 W.; Beaverhead County; along the north side of the east fork of Blackta1l Deer Creek. Mapped as Blacktail Deer Creek Formation by Scholten and others (1955, P1. 1). Strike 30 ; dip $5^{\circ}$ to NW.

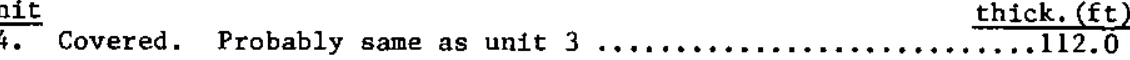

3. Conglomerate ( $40 \%)$, well sorted, metamorphic; yellowish gray with subrounded cobbles of metamorphic rocks (80\%) and limestone (20\%), in a matrix of poorly sorted, very coarse grained, sandstone; very hard, compact; cliff former; calcareous cemented; tabular even; thick bedded; internal massive bedding. Lower contact sharp, irregular.

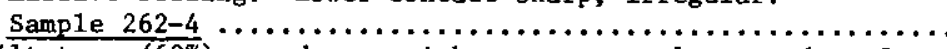
siltstone $(60 \%)$, sandy; grayish orange; poorly sorted; soft, compact; slope former; calcareous cemented; tabular even; thick bedded; internal massive bedding. Lower contact sharp, regular. Trace of heavy minerals (primarily).

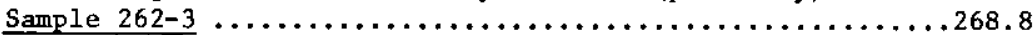

2. Sandstone, tuffaceous; light gray; medium grained, well sorted; medium hard, compact; cliff former; slightly iron-stained; tabular even; internally medium bedded with trough crossbedding. Lower contact sharp, regular. Trace of heavy minerals (primarily). Units grades from $90 \%$ glass fragments in lower portion to $50 \%$ glass fragments in upper portion.

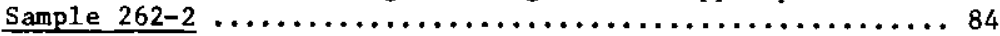

1. Stltstone, sandy; dull yellow orange; poorly sorted; medium hard, compact; slope former; calcareous cemented; tabular even; internally parallel even thick bedded. Minor carbonaceous material; trace of heavy minerals (magnetite). Unit contafins minor conglomeratic layers. Sample 262-1 ……145.6

Tota1 measured thickness .610 .4 


\section{LOCALITY 265. GRANT}

NW $\frac{1}{4} \mathrm{NW}^{\frac{1}{4}} \mathrm{SE} \frac{1}{4} \mathrm{sec} .31, \mathrm{~T} .9 \mathrm{~S} .$, R. 12 W.; Beaverhead County; in roadcut along Horse Prairie Creek. Mapped as Tertiary sediments undifferentiated by Ross and others (1955), but are 1tthologically similar to "Medicine Lodge" beds mapped to the southeast by Scholten and others (1955, P1. 1). Strike $240^{\circ}$; dip $6^{\circ}$ to north.

$\begin{array}{ll}\text { Unit } & \text { Estimated } \\ \text { thick. (ft) }\end{array}$ bedded. Subordinate carbonaceous material (leaf imprints).. 15

1. Sandstone; hard, compact; medium beds $\ldots \ldots \ldots \ldots \ldots \ldots \ldots \ldots, 2$

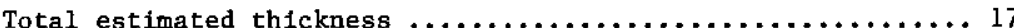

\section{LOCALITY 267. EVERSON CREEK}

$\mathrm{NE}_{4} \frac{1}{4} \mathrm{SE}_{4}^{\frac{1}{4} \mathrm{SW}_{\frac{1}{4}}}$ sec. 33 , T. 10 S., R. 14 W.; Beaverhead County; in cliffs west of Horse Prairie Creek. Approximately $350 \mathrm{feet}$ of section exposed. Consisting primarily of lacustrine volcanic siltstone composed of $50 \%$ glass, $25 \%$ basalt fragments and minor sands.

\section{LOCALITY 301. THREE FORKS AREA 1-A}

$\mathrm{SE}_{2} \mathrm{NE}_{\frac{1}{2}} \mathrm{SE}_{4} \frac{\mathrm{s}}{4}$ sec. 11, T. I N., R. I E.; Gallatin County; in small westerlydraining gully; in type area of Climbing Arrow Formation (Robinson, 1963, p. 70). This section, which contains a higher proportion of sand than average, is otherwise typical of the formation. Strike N. $35^{\circ}$ E., dip $4^{\circ}$ NW.

$\frac{\text { Unit }}{5}$

Measured

5. Sandstone, micaceous; pale olive; fine to very fine grained moderately sorted, with angular grains; soft, friable slope former; tabular even; internally massive. Lower contact gradational. Subordinate heavy minerals. Sample

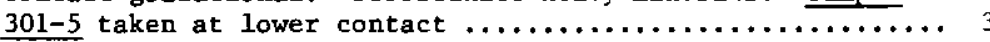

4. Sandstone; dusky yellow; fine grained (coarsens downward), moderately sorted, with subangular grains; soft, friable; slope former; tabular uneven; internally masstve. Lower contact sharp, regular. Subordinate biotite. Sample 301-4. 8.3

3. Claystone, bentonitic; light olive; medium hard, brittle; slope former; lentic, bed; internally massive. Lower contact gradational. Sample 301-3 taken at lower contact where the unit is more sandy.

2. Sandstone, feldspathic; dark yellowish orange; medium to coarse grained, moderately sorted, with subangular grains; medium hard, friable; slope former; lentic, channel; internally very thin bedded with cross-bedding. Contains clayballs and minor amount of biotite. Lower contact sharp and irregular. Stained with iron oxides in a pattern suggestive of a roll front. Sample 301-2. Sample 301-6 taken from black cemented (pyrolusite) layer about 25 feet south of the measured section near the middle of

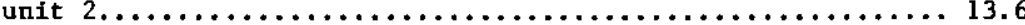

1. Sandstone, arkosic; dusky yellow and streaked; medium grained, moderately sorted, with subangular grains; soft, friable; slope former; lentic. Minor biotite. Sample 301-1 ….....

Total measured thickness $\ldots \ldots \ldots \ldots \ldots \ldots \ldots \ldots \ldots \ldots \ldots \ldots \ldots$ 28

\section{LOCALITY 302. THREE FORKS AREA 1-B}

SWh $\mathrm{SWR}_{\frac{1}{4} \mathrm{NW} / \frac{1}{4}}$ sec. 12, T. 1 N., R. 1 E.; Gallatin County; type area of the Climbing Arrow Formation (Robinson, 1963, p. 70). This section is characteristic of the formation in the Three Forks basin south of the Jefferson River. It contains $31 \%$ medium to coarse grained, poorly sorted sandstone in beds that range from 0.5 to 16.4 feet thick and average 5.3 feet thick. The upper third of the section duplicates the section of the climbing Arrow Formation measured by Robinson (ibid). Strike north $52^{\circ}$ east; dip $2.5^{\circ}$ east. 
Unit Sandstone, silty; medium brownish green; fine to very fin slope former; internally massive. Lower 2 feet micaceous with parallel uneven laminae. Lower contact sharp, ir-

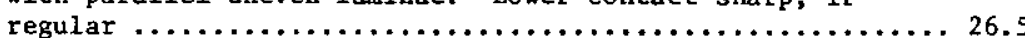

30. Sandstone, feldspathic; light greenish brown; medium grained, with subangular grains; soft, friable; slope former. Lowe contact sharp, irregular. Minor biotite.............. 3.4

29. Siltstone, sandy; poorly sorted; soft, friable; slope former Lower contact sharp, irregular and intensely iron-stained. M1nor biotite .................................. 11.2

28. Sandstone, subfeldspathic; light brownish gray; medium grained, poorly sorted; soft, friable. Lower contact sharp, irregular and Iron-stained. Minor blotite ................... 4.4

27. Claystone, silty; light olive; medium hard, compact; slope former; internally massive (laminated near base). Lower contact sharp, irregular. Minor biotite and, near the base, carbonaceous material. Sample 302-9 taken at base where unft is sandy $\ldots \ldots \ldots \ldots \ldots \ldots \ldots \ldots \ldots \ldots \ldots \ldots \ldots \ldots \ldots \ldots \ldots \ldots, 11.6$

26. Sandstone, arkosic; dusky yellow with yellowish brown mottles; medium grained (locally very coarse grained), moderately sorted with subangular grains; soft to hard, friable; cliff former; locally iron-stained; lentic, channel. Minor biotite and smokey quartz. Contains clay balls. Sample 302-8 cemented with iron oxides; Sample 302-7 without iron oxides. 13.4

25. Claystone, silty; medium brownish green; soft, brittle. Lower

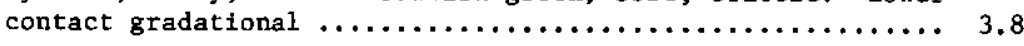

24. Sandstone, silty, subfeldspathic; dusky yellow; medium grained, poorly sorted with subrounded to subangular grains; soft, frlable; slope former. Lower contact sharp, irregular. Iron-8ta1ned at upper contact. Sample 302-6 includes black organic (?) material that locally coats sand grains ....... 7.8

23. Siltstone, clayey; medium brownish green; medium hard, friable; slope former; Internally massive. Lower contact sharp, trregular. .................................... 16.5

22. Sandstone, feldspathic; light grayish brown; medium grained, moderately sorted, with subangular grains; soft, friable. Lower contact sharp, irregular. Contains clay balls and

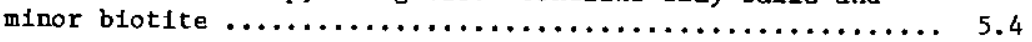
grained, poorly sorted, with subangular grains; medium hard,
compact; slope former; internally massive. Lower contact sharp, irregular. Minor biotite .................... 16.7

20. Claystone (89\%), silty; medium brownish green, medium hard, compact; slope former; internally massive. Lower contact gradational. Minor blotite. Unit coarsens downward to sandstone.

Sandstone (11\%), subfeldspathic; 11ght yellowish gray, medium to coarse grained, moderately sorted; soft, friable; slope former. Forms thin beds in upper $1 / 2$ of undt. Lower

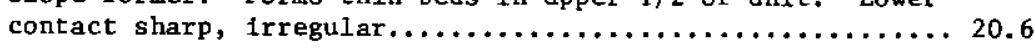

19. Sandstone, quartz; 11ght yellowish brown; medium grafned, poorly sorted, with subangular grains; soft, friable; slope former; fron-stained at upper and lower contacts; internally massive. Lower contact sharp, irregular. Minor biotite ... 2.4

18. Claystone, silty; medium brownish green; medium hard, compact; slope former; internally massive. Lower contact gradational. Minor biotite. Unit coarsens near base to sandstone ...... 26

17. Sandstone, quartz; 1ight brownish yellow; banded with iron-staining; medtum (near top) to coarse grained (at base), moderately sorted, with subangular grains; medium hard, friable; slope former; lentic, channel. Lower contact sharp, irregular. Trace of biotite....................... 7

16. Sandstone, silty; (fines upward to blocky claystone near top) medium brownish green and mottled with iron-staining; very fine grained, moderately sorted; soft, friable; slope

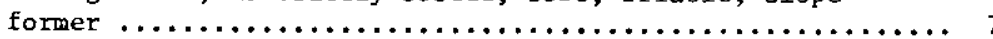

15. Sandstone, quartz; Iight yellowish brown and banded with ironstaining; medium to coarse grained, moderately sorted, with subangular grains; soft, friable; slope former; tabular uneven. Lower contact sharp, Irregular. Minor biotite.... 3.7

14. Claystone, silty; moderate olive brown; soft, plastic; slope former. Lower contact gradational. Sample 302-5; sample 302-4 of clay with purplish coating $\ldots \ldots \ldots \ldots \ldots \ldots \ldots \ldots \ldots \ldots \ldots \ldots \ldots .2$

13. Sandstone (90\%), feldspathic; yellowish gray; medium to coarse grained, moderately to poorly sorted, with subangular grains medium hard, friable; steep slope former; tabular uneven; internally cross-bedded. Lower contact gradational. Contains clay balls and minor biotite. Sample $302-3 \ldots \ldots \ldots$. ......

Claystone and siltstone (10\%); 1ight gray to orangish gray with some reddish brown Iron-stained layers. Very thin to thin forms beds and lenses................................ 10.4 .

Note: of $f$ set about 500 feet across covered interval. Correiation of this unit is based on (1) lateral continuity of sandstone beds in the unft and (2) lithologic characteristics. 
LOCALITY 302. (continued)

Unit 12 . Claystone; dark brownlsh green; medium hard, frlable; slope former. Contains thin bed of Iron-stained, coarse grained

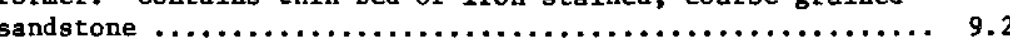

11. Sandstone, silty; medium greenish brown; very fine grained, medium hard, frangible; slope former; Iron-stained, in part. 10

10. Sandstone; medium yellowish gray; medium grained, poorly sorted, with subangular grains; medium hard, friable; slope former; lentic channel; Internally massive. Lower contact sharp, irregular. Contains very thin bed of coarse grained sandstone with subordinate clay pebbles ................... 3.

9. Sandstone, silty and clayey; dark brownish green with purplish bands; very fine grained; medium hard, compact; slope

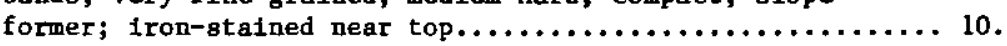

8. Sandstone, feldspathic; dusky yellow; fine to coarse grained, poorly sorted, with subangular grains (10-15\% granite clasts, very coarse-sand-sized, and subrounded); soft, friable; slope former; locally iron-stained; lentic channel. Minor slope former; locally iron-stained; lentic channel. Minor amount of biotite. Lower contact covered. Unit becomes Sample 302-1 is of the Iron-stained portion; Sample 302-2 1s of the non-stained portion.......................... 8.4

7. Sandstone; Iight yellowish gray, coarse grained, poorly sorted, with subangular grains; soft, friable; slope former; ironstaining at upper and lower contacts ................. 8

6. Claystone, sandy; medium greenish brown; medium hard, compact; slope former $\ldots \ldots \ldots \ldots \ldots \ldots \ldots \ldots \ldots \ldots \ldots \ldots \ldots \ldots \ldots, 4.3$

5. Sandstone; light yellowish gray; with coarse, angular grains; medium hard, friable; slope former; iron-stained at upper and lower contacts. Minor biotite ...................

4. Claystone, silty; dark greentsh brown; medium hard to hard, brittle; slope former; internally massive. Lower contact

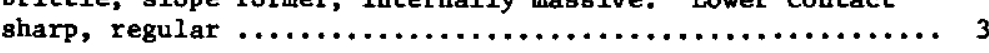

3. Sandstone, quartz; medium brownish yellow; medium grained moderately to well sorted, with subangular grains; medim hard, friable; slope former; 1ron-stalned at the top; lentic channel; internally cross-bedded. Minor heavy minerals .... 3.6

2. S1ltatone; medim yellowish brown; hard, frlable; slope former; Interfingers with sandstone to the west $\ldots \ldots \ldots \ldots \ldots \ldots \ldots \ldots \ldots \ldots \ldots \ldots$

1. Sandstone; 1ight grayish yellow; medium grained, poorly sorted, with subangular grains; soft, friable; slope former ....... 3.9

\section{LOCALITY 303. WEST MILLIGAN CANYON ROAD}

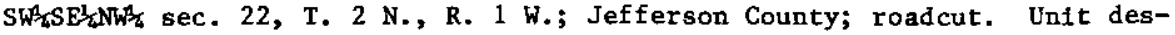
cribed 1s near the base of the more than 80 feet of Climbing Arrow Formation mapped by Robinson (1963, pp. 69-77, Pl, 1) at this location.

Unit

I. Sandstone, feldspathic to arkosic; yellowlsh gray, with dark yellowish orange streaks; medium to very coarse grained, poor1y sorted, with subangular grains; medlum hard, friable; cliff former; lower half calcareous and iron-stained; lentic channel; internally thin bedded with trough crossbeds. Contains clay balls and minor blotite and muscovite. Localized pebble lenses are composed of quartzite and volcanic rocks. Sample 303-2 representative of unit; sample 303-1 taken

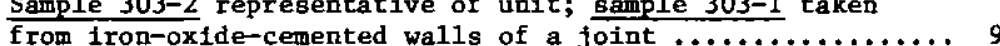

\section{LOCALITY 304. G. BALLARD RANCH 1}

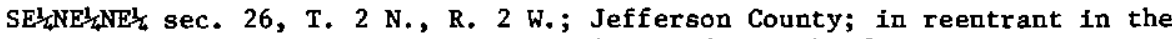
south side of an ENE trending ridge, 125 yards north of Cottonwood Canyon Road. Mapped as Tertiary Bozeman Group by Richard (1966, P1. 1). Correlated with the Climbing Arrow Formation of Robinson (1963, pp, 69-77, PI.

1) on the basis of 1ithologic characteristics and stratigraphic position. Strike north $15^{\circ}$ east, dip $4^{\circ}$ east.

Unit 13 . Claystone; dark brownish green; medium hard, friable; slope thick. (ft) former; tabular even; internally massive. Lower contact sharp, regular $\ldots \ldots \ldots \ldots \ldots, \ldots \ldots \ldots \ldots \ldots \ldots \ldots \ldots, 9.2$

12. Ash, vitric; 1ight gray; soft, loose; slope former; tabular even; internally parallel even, very thin bedded. Lower contact sharp, regular. Sample $304-4 \ldots \ldots \ldots \ldots \ldots \ldots \ldots \ldots \ldots \ldots \ldots \ldots .2$

11. Tuff, vitric; pale greenish yellow; medium hard, brittle; slope former; tabular even; Internal parallel even, very thin to laminated bedding. $35 \%$ glass shards. Lower contact sharp, regular. Sample $304-3 \ldots \ldots \ldots \ldots \ldots \ldots \ldots \ldots \ldots \ldots 1,2$

10. Claystone (coarsens upward into siltstone); medium greenish yellow at bottom to dark yellowish brown at top; medium hard, brittle; slope former; laternally massive. Lower contact sharp $\ldots \ldots \ldots \ldots \ldots \ldots \ldots \ldots \ldots \ldots \ldots \ldots \ldots \ldots \ldots . . .6$

9. Sandstone; light greenish yellow; fine grained, poorly sorted, with subangular grains; soft, friable; slope former. Lower contact sharp, regular. Minor blotite ............... 1.8

8. Tuff; light whitish green; medium hard, friable; slope former; internal parallel even laminae. Lower contact sharp, regular. Hackley surface on unweathered laminae .........4.8 
brittle; slope 85\%); medium yellowish green; medium hard,

Sandstone (lower 15\%)

with subangular grains; slope former. Lower contact sharp,

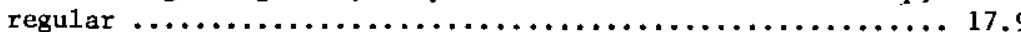

6. Claystone, bentonitic, tuffaceous, micaceous; medium grayish green; soft, franglble; slope former; internally massive. Lower contact sharp, irregular. Subordinate biotite ..... 4

5. Sandstone, subfeldspathic; medium brownish gray; medium grained, poorly sorted, with subangular grains. Lower contact sharp, regular. Minor biotite $. \ldots \ldots \ldots \ldots \ldots \ldots \ldots \ldots \ldots \ldots \ldots, 0.3$

4. Claystone; medium brownish green with brownish orange (ironstained) mottles; soft, compact; slope former; interna11y massive. Lower contact sharp, irregular ............... 9.1

3. Sandstone, feldspathic; yellowish brown; medium to coarse grained, poorly sorted, with subangular grains; soft, friable; slope former; locally calcareous cemented parallel to bedding; Iron-stained. Lower contact sharp, irregular. Trace of biotite; minor magnetite. Sample 304-2 ............. 4.4

2. Claystone, silty, bentonitic; grayish olive; soft, frangible; iron-stained. Lower contact sharp, irregular. Fines upward to plastic brownish green clay. Sample 304-1 …........ 7.8

1. Sandstone; medium orang1sh brown; fine to medium grained, moderately sorted, with subangular grains; medium hard, friable; slope former, iron-stained $\ldots \ldots \ldots \ldots \ldots \ldots \ldots \ldots, 0.2$

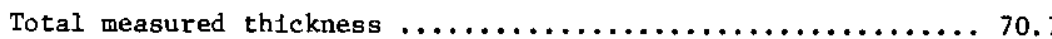

\section{LOCALITY 305. MILLIGAN CREEK CONGLOMERATE}

$\mathrm{SW}_{\frac{1}{4}} \mathrm{SE}_{\frac{1}{4} \mathrm{NW}}$ sec. 1, T. I N., R. 1 W.; Jefferson County; north side of gulch. Milligan Creek Formation of Robinson (1963, pp. 64-69, P1. 1).

$\frac{\text { Unit }}{3 .}$ Covered (1imestone and marlstone float) to top of hill ...... $\frac{\text { thick. (ft) }}{30.8}$

Measured

2. Conglomerate (55\%), sandy; light gray (weathers to grayish brown); with subangular to subrounded pebbles of volcanic rocks $(45 \%)$, quartzite $(40 \%)$ and granite (15\%), in a silicified matrix of poorly sorted, angular to subangular, medium to very coarse grained micaceous, arkosic sandstone; in medium thick beds; hard, friable; cliff former; locally calcareous; permeable. Trace of magnetite. Anomalously radio-

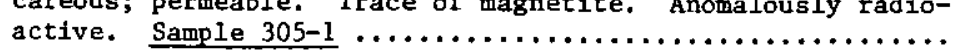

2. (cont.) Sandstone (45\%), conglomerat1c, arkosic; 11ght gray (weathers to pale yellowish brown; medium to very coarse grained, poorly sorted; with subangular pebbles of quartzite (50\%), porphyrit1c mafic rocks (30\%), and granite $(20 \%)$; hard, brittle; ledge former, cemented with a mixture of chalcedony and quartz (locally calcareous); slightly permeable; medium thick lentic channel; internally thin to medium bedded with planar cross-bedding. Lower contact medium bedded with planar cross-bedding. Lower contact
covered. Minor magnetite and biotite. Sample 305-2. More 11thified than the conglomerate. Radioactivity appears to correlate with degree of cementing within this unit $\ldots \ldots \ldots 11$

1. Covered (1imestone and marlstone float) $\ldots \ldots \ldots \ldots \ldots \ldots \ldots . \ldots \ldots .2$

Total measured thickness 97

\section{LOCALITY 306. G. BALLARD RANCH No. 2}

$\mathrm{SE}_{4}^{\frac{1}{4}} \mathrm{SE}_{\frac{1}{4} \mathrm{SW}}^{\frac{1}{4}} \mathrm{sec}$. 24, T. 2 N., R. 2 W.; Jefferson County; 265 feet ENE of two prominent tuff beds which crop out just north of the obtuse corner of Cottonwood Canyon Road. Strike north $18^{\circ}$ east and dip $6^{\circ}$ east. Section seems to stratigraphically overlie section 304. Mapped as the Tertiary Bozeman group by Richard (1966, P1. 1); correlated with the Climbing Arrow Formation of Robinson (1963, p. 69-77, P1. 1) on the basis of Iithologic characteristics and stratigraphic position.

Unit

Measured laystone; medium purp1ish brown; soft; slope former, internally massive. Lower contact gradational $\ldots \ldots \ldots \ldots \ldots \ldots \ldots \ldots 1.8$

9. Sandstone (2 inch beds interbedded with clayey siltstone similar to unit 8); medium brownish orange; medium grained, moderately sorted, with subangular grains; soft, loose; slope former;

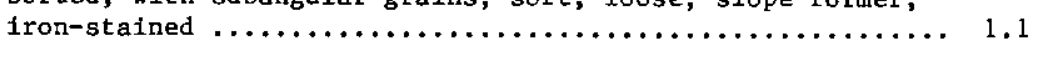

8. Siltstone, clayey (grades to silty claystone and back); medium greenish brown; soft, friable; slope former; internally massive. Lower contact gradational. Slight reddish stain-

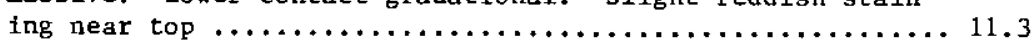

7. Sandstone, silty and clayey; medium brownish gray, fine to medium gralned, very poorly sorted, with subangular grains; soft, friable; slope former; internally massive; lower con-

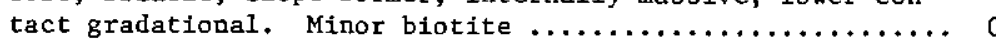

6. Claystone (85\%), silty, bentonitic; medium greenish brown to dark slightly reddish brown; slope former $\ldots \ldots \ldots \ldots \ldots \ldots$ Siltstone (15\%), grading to fine grained sandstone; medium yellowish brown, slope former ......................1

Comments: Lower contact of unit is sharp. Contacts within the unit are gradationa1. 
Sandstone, quartz; medium brownish gray; medium grained, moderately sorted, with angular grains; soft, loose; slope former. Lower contact gradational. Minor biotite ............... 1.1

4. Sandstone, feldspathic; iron-stained to grayish orange with unstained medium yellowish gray bands; fine to coarse grained, moderately sorted, with subangular to angular grains; hard to medium hard, friable (laterally soft, loose); ledge former; silica cemented (laterally uncemented; slope former); lentic channel; internally very thin bedded wh planar cross-bedchannel; internally very thin bedded whe planar cross-bedof silicifled wood. Iron-staining occurs in the coarser portions of unit and surrounds the silicified wood fragments. Higher radioactivity occurs adjacent to the silicified wood.

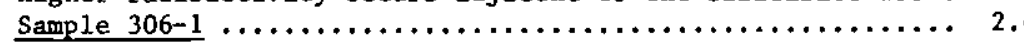

3. Sandstone, clayey, subfeldspathic; medium yellowish green; fine grained, moderately sorted, with subangular grains; soft, friable; slope former. Lower contact gradational. Trace to minor biotite $\ldots \ldots \ldots \ldots \ldots \ldots \ldots \ldots \ldots \ldots \ldots \ldots, 2.3$

2. Claystone, silty; 11ght to medium yellowish green; soft, plastic; slope former. Lower contact gradational ........... 2 .

1. Claystone, sandy and silty; medium brown; soft, franglble; slope former $\ldots \ldots \ldots \ldots \ldots \ldots \ldots \ldots \ldots \ldots \ldots \ldots \ldots \ldots \ldots, 2.5$

Total measured thickness

\section{LOCALITY 308. SHODDY SPRINGS}

SWh $\mathrm{NE}_{\frac{1}{4}} \mathrm{SW}_{\frac{1}{4}}$ sec. 3, T. 2 N., R. 1 W.; Jefferson County; water sample 308-1 from stream adjacent to the house on the Silver Sage Ranch. Water apaparently rises from Climbing Arrow Formation of Robinson (1963, pp. 69-77, P1. 1).

\section{LOCALITY 309. SILVER SAGE NO. I}

$\mathrm{St}_{2} \mathrm{SE}_{\frac{1}{4}} \mathrm{SE}_{\frac{1}{4}}$ sec. 2, T. 2 N., R. 1 W.; Jefferson County; 100 feet north of road to Silver Sage Ranch. Climbing Arrow Formation of Robinson (1963, pp. 69$77, \mathrm{P} 1.1$ ). Strike north $60^{\circ}$ west; dip $5^{\circ}$ northeast.

Unit 7. sratned, poorly sorted. with subangular grains; soft, loose; slope former. Lower

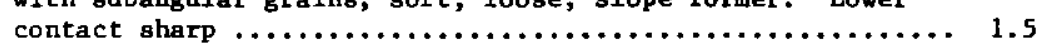

6. Claystone, silty, micaceous in middle; medium greenish brown to reddish brown; soft, frangible (plastlc at base); slope former; tabular even; Internally massive. Lower contact sharp, regular $\ldots \ldots \ldots \ldots \ldots \ldots \ldots \ldots \ldots \ldots \ldots \ldots \ldots, 1.5$

LOCALITY 309. (continued)

5. Sandstone, silty; medium brownish gray; medium grained at bottom, fining upwards to very fine grained at top, poorly sorted, with subangular graing; soft, friable; cliff forer. Lower contact sharp. Contalns clay balls and minor biotite. 1.7

4. Siltstone, clayey (micaceous at base); dark greenish gray (pinkish brown in middle); tabular uneven; internally massive. Lower contact sharp, regular ...................

3. Sandstone, subfeldspathic; 1ight gray; fine to coarse grained, poorly sorted, with subangular grains; medium hard, brittle; cliff former; iron-stained in lower portion; lentic channel; internally very thin bedded. Lower contact sharp, irregular. Contains some balls and laminae of light pink, translucent clay in lower portion. Minor heavy minerals (biotite and magnetite). Sample 309-2 of finer lower portion. The following sample was taken 175 feet ESE of the measured section in a 9-inch thick bed which probably is equivalent to this

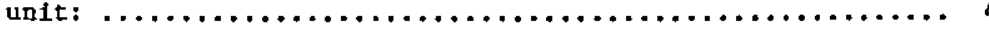

Sample 309-3. Sandstone; yellowish gray and banded; fine to medium grained, poorly sorted, with subangular grains; medium hard, frlable; ledge former; internally thin bedded with planar cross-bedding. Trace of biotite.

2. Claystone; pale yellowish brown to pale brown; soft, brittle; slope former. Lower contact sharp. Sample 309-1 ........ 1.7

1. Sandstone (75\%), medium yellowish gray; fine grained, moderately sorted, with subangular grains; soft, friable; slope

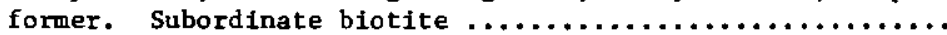
Claystone (25\%), silty; dark brownish gray; soft, frangible;

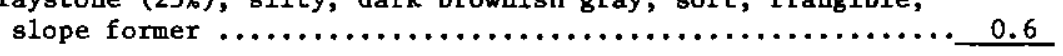

Total measured thickness 12.6

\section{LOCALITY 310. JOHNSTON FARM}

SE $\frac{1}{4}$ SW 3 NWt sec. 16, T. 2 N., R. 1 E.; Broadwater County; about 500 feet east of I1ne between sections 16 and 17. Climbing Arrow Formation of Robinson (1963, pp. 69-77, P1. 1). Strike north $62^{\circ}$ west; dfp $2^{\circ}$ northeast.

$\underline{\text { Unit }}$

Measured

11. Sandstone, clayey, tuffaceous; medium yellowish brown; medium grafned, poorly sorted, with subangular grains; soft. loose; slope former. Lower contact sharp .............. 1.8

10. Claystone (silty near base), bentonitic; medium greenish brown to reddish brown; soft, frangible; slope former; internally massive. Lower contact sharp, regular ................ 5 


\section{LOCALITY 310. (continued)}

Unit

portion); light gray; medium grained, moderately sorted, with subangular grains; soft, frlable; steep slope former; lentic channel. Lower contact sharp, regular. Contains clay ba1ls.

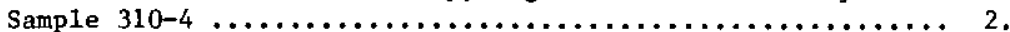

8. Claystone, coarsens to clayey siltstone in upper portion; medium greenlsh brown; soft, plastic; slope former; tabular even; Internally massive. Lower contact sharp, regular .... 1.8

7. Sandstone, (upper one third finer grained, clayey, tuffaceous and bentonitic); medium orangish gray; medium grained, poorly sorted, with subangular grains; soft, loose; steep slope former; moderately 1ron-stalned; lentic channel. Lower contact sharp. Contains some petrified bone fragments

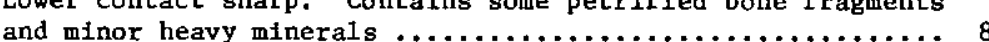

6. Sandstone, tuffaceous (fines upward to sandy claystone), bentonitic; grayish olive; fine to medium grained, poorly sorted, with subangular grains; soft, friable; steep slope former; locally iron-stained; lentic. Lower contact sharp. Trace of silicified wood and bone fragments. Minor magnetite, and 10-20\% pumice granules. Sample 310-3 taken from thear the bottom contact

5. Claystone, silty; dusky yellow; medium hard, brittle; slope former. Lower contact sharp. Sample 310-2 taken near the

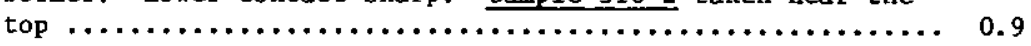

4. Sandstone, tuffaceous/vitric tuff; yellowish gray; fine grained, moderately sorted, with subangular grains; soft, friable; steep slope former. Lower contact covered. Minor biotite and petrified wood. Sample $310-1, \ldots \ldots \ldots \ldots \ldots \ldots \ldots \ldots, 0.7$

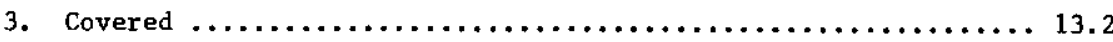

2. Claystone; medium grayish brown and mottled (weathers to light brownish gray); medium hard, brittle; slope former; 1ronstained; lentic bed; internal parallel very thin bedding. Interbedded with siltstone in lower part .............. 4.2

1. Sandstone; light yellowish gray; medium to very fine grained (fines upward), with subangular grains; medium hard, friable; steep slope former; lentic channel. Trace petrified wood; minor heavy minerals. Very thin black layer of manganese oxide or carbonaceous material near top $\ldots \ldots \ldots \ldots \ldots \ldots \ldots .6 .4$

Total measured thickness

\section{LOCALITY 311. DUNBAR CREEK TYPE AREA}

Elr sec. 7, T. 1 S., R. 2 E.; Gallatin County; rype area of Dunbar Creek Formation (Robinson, I963, pp. 77-81, Pl. 1). Unit described is probably unit 1 of Robinson's measured section $G$ (p. 78, PI. 2).

Estimated

$\frac{\text { Unit }}{1 .}$ Sandstone, feldspathic; yellowish gray; coarse grained, moderately sorted, with angular to subangular grains; very hard, brittle; cliff former; permeable; clay (?) cemented. Minor biotite. Sample $311-1 \ldots \ldots \ldots \ldots \ldots \ldots \ldots \ldots \ldots \ldots \ldots, 8,10$

\section{LOCALITY 312. SILVER SAGE No. 2}

Center SE $\frac{1}{4} \mathrm{SW}_{\frac{1}{4}}$ sec. 3, T. 2 N., R. 1 W.; Jefferson County; top of northern knob between east-west gravel road and eastern driveway to Silver Sage Ranch. Climbing Arrow Formation of Robinson(1963, pp. 69-77).

1. Limestone, aphanitic; grayish yellow and speckled (weathers to light gray); hard, brittle; surficially iron-stained. Manganese dendrites. Sample $312 \sim 2$ characteristic of unit. Sample 312-1 of anomalously radioactive part of unit with minor carbonized wood. Anomaly seems confined to a point source.

\section{LOCALITY 313. CHERRY CREEK FAULT SECTION}

Center $W_{2}$, sec. 26, T. 2 S., R. I E.; Madison County; Units 1 and 2 describe below probably correspond to units 21 and 22, respectively, of section I of Feichtinger (1970, pp. 65-68, P1. I and II). Dunbar Creek Formation of Robinson (1963, pp. 77-81). bles of volcantc rocks, granite and quartz, in a matrix of medium to very coarse grained, poorly sorted sand; hard, friable; ledge former; calcareous cemented; tabular uneven; channel; internally medium bedded with planar cross-bedding. Lower contact erosional with less than 1 foot of relief. Minor heavy minerals (amphibole, magnetite, and biotite).

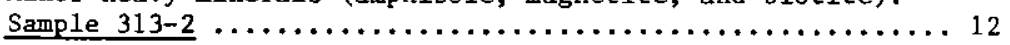

1. Siltstone, sandy; 1ight yellowish orange, with subangular, poorly sorted sand; soft, frlable; slope former; tabular uneven; internally massive. Minor amphibole. Contains peb-

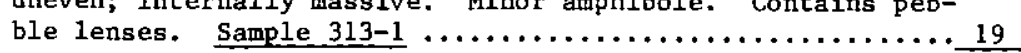

Total estimated thickness $\ldots \ldots \ldots \ldots \ldots \ldots \ldots \ldots \ldots \ldots \ldots \ldots, \ldots \ldots$ 
NW $\frac{1}{4} \mathrm{NE}_{4}^{\frac{1}{4}} \mathrm{SE}_{\frac{1}{4}} \mathrm{sec} .18$, T. 1 S., R. 2 E.; Gallatin County; north side of small east-trending draw adjacent to Madison River. Dunbar Creek Formation of Robinson (1963, pp. 77-81), as mapped by Feichtinger (1970, P1. 1).

Unit th1ck. (ft)

13. Conglomerate, pebble; poorly sorted; ledge former ........ 5

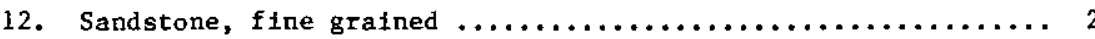

11. Sandstone; medium grafned to pebbley; channel (?); 1ight1y iron-stained, cross-bedded $. . \ldots \ldots \ldots \ldots \ldots \ldots \ldots \ldots, 6 \ldots \ldots, \ldots \ldots$

10. Sandstone; fine grained; ledge former $\ldots \ldots \ldots \ldots \ldots \ldots \ldots . . \ldots$

9. Sandstone, silty; fine grained; ledge former $\ldots \ldots \ldots \ldots \ldots \ldots 6$

8. Sandstone, feldspathic; dull yellowish brown and streaked (weathers to grayish brown); coarse grained, moderately sorted, with angular to subangular grains; hard, compact; ledge former; cemented with fron oxides; lentic channel; internal trough cross-bedding. Lower contact sharp, irregular.

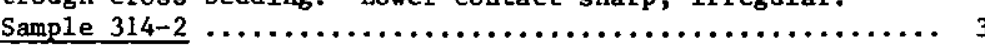

7. Siltstone; yellowish gray (weathers to light gray); medium hard, friable; slope former; tabular uneven; 1nternally massive. Lower contact sharp, irregular. Minor carbonaceous material.

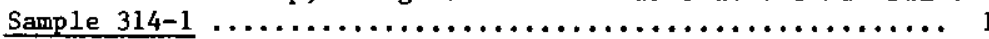

6. Siltstone $(50 \%)$

Sandstone $(50 \%)$, fine 8 rain

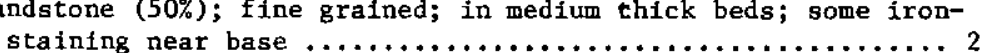

Sandstone (locally silty or conglomeratic); light gray; fine grained; tabular; internally medium bedded .............. 30

4. Sandstone, conglomeratic; coarse to medium grained; some ironstaining; internally cross-bedded . ....................

3. Sandstone (95\%); 1ight gray; both fine grained (74\%) and medium grained (26\%) beds, poorly sorted; ledge former;

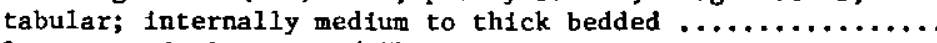

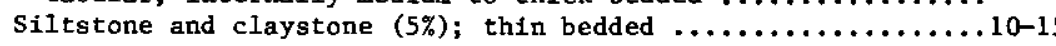

2. Sandstone, conglomeratic; dul1 yellow and streaked; medium gralned, poorly sorted, with subrounded pebbles; medium hard, compact; iron-stained; tabular uneven; internally trough cross-bedded. Lower contact sharp, irregular. Minor biotite and muscovite; trace of volcanic glass. Probably channel. Sample $314-4$ collected at bottom $\ldots \ldots \ldots \ldots \ldots \ldots \ldots \ldots \ldots$, ilt with fine grained, poorly sorted sand; medium hard, brittle; tabular even; interna1ly massive. Sample 314-3 collected at

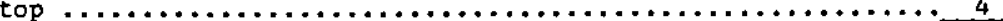

Total estimated thickness $.108-113$

\section{LOCALITY 315. NORTH JORGENSON DITCH}

$\mathrm{NE}_{\frac{1}{4}} \mathrm{SE}_{\frac{1}{4}} \mathrm{NW} \frac{1}{4}$ sec. 19, T. 1 S., R. 2 E.; Gallatin County; north side of broad draw trending east to the Madison River. Units 1 and 2 described below probably correspond to units 15 (upper portion) and 16, respectively, of stratigraphic section IV of Felchtinger (1970, pp. 74-78, P1. 2). Dunbar Creek Formation of Robinson (1963, pp. 77-81) as mapped by Feichtinger (1970, P1. 1).

Unit

Estimated

2. Sandstone, silty; dusky yellow and streaked; medium grained, poorly sorted (ranges from fine grafned to conglomeratic with subrounded pebbles of siltstone); medium hard, friable; iron-stained; lentic channel; internal trough cross-bedding. Lower contact sharp, irregular. Minor biotite and muscovite. $\frac{\text { Sample } 315-2}{\text { dish brown }}$. Lower contact is iron cemented and dark red-

1. Siltstone, tuffaceous; light yellowish gray (weathers to light gray); medium hard, compact; lentic channel; internally massive. Contains manganese (?) dendrites and probable root casts. Sample $315-1 \ldots \ldots \ldots \ldots \ldots \ldots \ldots \ldots \ldots \ldots \ldots \ldots \ldots \ldots \ldots \ldots \ldots, 0.3$

Total estimated thickness

\section{LOCALITY 316. REY CREEK}

Center $\mathrm{NE}_{4}^{\frac{1}{4} \mathrm{SE}_{\frac{1}{4}}}$ sec. 4, T. 1 N., R. 2 E.; Gallatin County; due east of Christlansan Ranch. Units 2, 4, 5, and 7 probably correspond to units 9 , 12,13 , and 21 , respectively, of stratigraphic section III of Schneider (1970, pp. 54-56). Un1t 2 is from Schneider's "Lower Unit", which is of Miocene age. Units 4 and 5 are from the lower portion of Schneider's "Middle Unit" which 18 also of Miocene age. Unit 7 is from basal portion of Schneider's "Upper Unit" which is of Pliocene age (p. 12).

Estimated

8. Not described thick. $(\mathrm{ft})$

7. Sandstone; yellowish gray and streaked; fine grained, well sorted; soft, frlable; locally calcareous; internal very thin to laminated cross-bedding. Minor muscovite; ironstained along laminae. Description and sample $316-1$ taken 
5. Sandstone, silty; yellowish gray; medtum grained, very poorly sorted, with subrounded grains; medium hard, friable; locally sorted, with subrounded grains: gedila hard, frtable cemented and streaked wh iron oxides (probably related to surface weathering). Contains clay balls and some very thin lenses of pebbly sandstone. Sample 316-4 from near base of

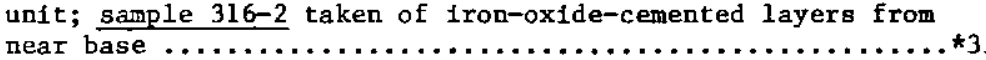

4. Sandstone, silty; light gray; very fine gralned, poorly sorted. Sample $316-3$ taken in upper part $\ldots \ldots \ldots \ldots \ldots \ldots \ldots \ldots \ldots \ldots * 20$

3. Not described .$* 10$

2. Conglomerate; dull yellowish brown; in a matrix of very poorly sorted, subangular to subrounded, very fine to very coarse silty sand; tabular uneven; iron-stafned. Lower contact erosional. Minor magnetite. Sample $316-5 \ldots \ldots \ldots \ldots \ldots \ldots * 3$

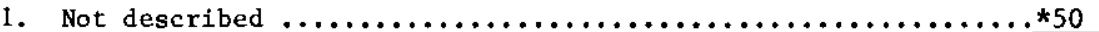

Total estimated thickness 289

*Thickness from Schneider (1970, p. 54-56).

\section{LOCALITY 317. SOUTHWEST SIDE HIGH FLAT}

$\mathrm{NWB}_{4} \mathrm{SW}_{4} \mathrm{R} W \frac{1}{4} \mathrm{sec} .6$, T. 3 S., R. 4 E.; Gallatin County; about 100 yards southwest of ranch road along ridge. Outcrop is of "the only lithologic unit constituting a marker horizon in the Mlocene section" (Mifflin, 1963, p. 20).

$\frac{\text { Unit }}{1 .}$ Estimated thick. (ft)

Sandstone, conglomeratic, subfeldspathic; light gray (weathers to grayish brown); coarse to very coarse grained, moderately sorted with angular grains and with pebbles of quartz (85\%), metamorphic rocks $(10 \%)$, and feldspar $(5 \%)$; very hard, brittle; ledge former; silica cemented; tabular even; interna1 parallel even medium beds. Subordinate hornblende. Sample 317-1. Unit apparently deposited unconformably against a hill composed of quartzites and other metamorphic

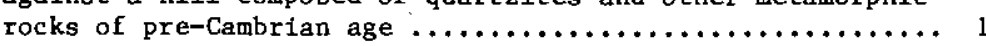

\section{LOCALITY 318. RED BLUFF GULCH}

NW $\frac{1}{4} \mathrm{NE}_{\frac{1}{4}} \mathrm{SW} \frac{1}{4}$ sec. 13, T. 3 S., R. 1 W.; Madison County; in north draining gulch. Red Bluff Formation of Andretta and Alsup (1960, p. 186). Strike north $74^{\circ}$ west; dip $6^{\circ}$ south. Bleaching and alteration may be hydrothermal in orig1n (Robert Levich, personal communication, 1975).

Unit

brittle; pebly; dark pink1sh brown; coarse grained, hard, brittle; cliff former; iron-stained at base; lentic bed; internally massive. Contains sand sized grains of pumice. Basal portion altered to soft, friable, iron-stained, yellow sandstone. Lower contact sharp, irregular. Sample 318-2 from the oxidized layer at base .................. 15.1

6. Siltstone, clayey, tuffaceous; 11ght gray; medium hard, brittle, bleached; tabular even; internally parallel even thin beds. Lower contact covered. Trace of organic material. Appears to be highly altered. Sample 318-1 $\ldots \ldots \ldots \ldots \ldots \ldots \ldots \ldots \ldots \ldots \ldots .8$

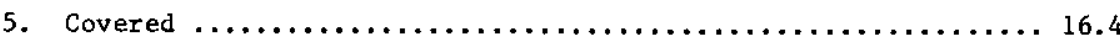

4. Conglomerate, arkosic; 1ight pinkish brown and mottled (weathers to medium orangish brown); with angular pebbles of feldspar; hard, brittle; ledge former; tabular uneven; internally medium bedded. Lower contact sharp, irregular. Contains some smoky quartz $\ldots \ldots \ldots \ldots \ldots \ldots \ldots \ldots \ldots \ldots \ldots \ldots \ldots, 5.2$

3. Sandstone, pebbly; light reddish gray; (weathers to purplish red); fine grained; hard, brittle; ledge former; siliceous or ferruginous cemented; iron-stalned; tabular uneven; internal parallel even very thin to thin beds. Lower contact gra-

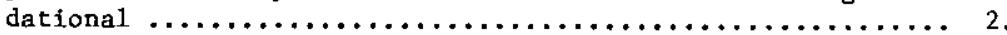

2. Conglomerate, sandy; light gray1sh purple (weathers to medium grayish purple); with angular pebbles of feldspar and quartz in a matrix of coarse grained, moderately sorted sandstone; medium hard, brittle; slope former; bleached; lentic channel; internally medium bedded. Lower contact sharp, regular.... 3

1. Conglomerate $(60 \%)$, sandy, arkosic; light whitish purple (weathers to dark grayish purple); w1th subangular pebbles of feldspar in a matrix of medium gratned, moderately sorted sandstone; hard, brittle; cliff former; possibly ferruginous cemented; iron-stained; medium thick lentic bed; internally cemented; iron-stained; medium thick lentic bed; internally parallel uneven, medium bedded $\ldots \ldots \ldots \ldots \ldots \ldots \ldots \ldots \ldots \ldots \ldots \ldots \ldots \ldots$
Sandstone $(40 \%)$, conglomeratic, subfeldspathic; medium grayish Sandstone ( $40 \%)$, conglomeratic, subfeldspathic; medfum gray
purple (weathers to dark purplish red); fine to medium grained, poorly sorted; hard, brittle; cliff former; medium thick lentic channel; internally medium bedded with crossbedding. Contains sand sized gratr

Total measured thickness $\ldots \ldots \ldots \ldots \ldots \ldots \ldots \ldots \ldots \ldots \ldots \ldots .9$

\section{LOCALITY 319. RED BLUFF WARM SPRING}

SW $\frac{1}{4} \mathrm{NW}^{1} \frac{1}{4} \mathrm{NE} \frac{1}{4} \mathrm{sec} .18$, T. 3 S., R. 1 E.; Madison County; Water sample 319-1 from spring on east side of road. Water is warm $\left(74^{\circ} \mathrm{F}.\right)$. 


\section{LOCALITY 320. CRANE SCHOOL}

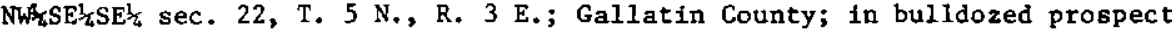
on low knoll, west side of south draining valley. Sixmile Creek Formation of Robinson (1967).

Unit

Siltstone; salmon pink; soft to hard; very calcareous where hard. Cut by veins of banded chalcedony which trend north $50^{\circ}$ east. Yellow powdery coating on siltsone pieces is identified as jarosite. Sample 320-1 taken of chalcedony and

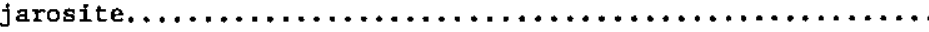

\section{LOCALITY 321. SLXMILE CREEK No. 1}

Center $W_{2} \mathrm{NE}_{\frac{1}{2}} \mathrm{sec}, 17$, T. 5 N., R. 3 E.; Broadwater County; at base, east side of low north-south ridge. Climbing Arrow Formation of Robinson (1967) Dip $25^{\circ}$ to $30^{\circ}$ to the east. The lower member of the formation is comprised of shales, lignites, bentonitic clays and conglomerates (ibid.). The conglomerates, which locally make up $10 \%$ to $20 \%$ of the member in this locality, are strongly cemented with carbonate or sllica, and are not permeab1e. The Ifgnites (unit 1 , below) are anomalously radioactive.

\section{Unit former; tabular even; internal parallel laminae. Contain jarosite along bedding plains. Sample 321-1 ...........}

\section{LOCALITY 322. DRY HOLLOW No. 1}

NEל,NEלNW/ sec. 6, T. 5 N., R. 3 E.; Broadwater County; on north side of hollow. Strike due north and dip $19^{\circ}$ west. Basal part of the Sixmile Creek Formation of Robinson (1967).

$\frac{\text { Unit }}{4 .}$ imilar to unit 2, but without pebbles thick. ( $f t)$

3. Sandstone, tuffaceous; fine grained. Predominately glass

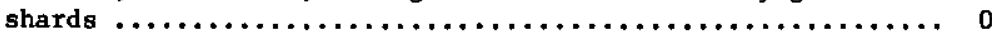

2. Sandstone, pebbly, tuffaceous; yellowish gray; fine to medium grained, moderately sorted, with angular grains and angular to subrounded pebbles; medium hard, friable; cliff former; calcareous cemented near base; tabular even; internally medium bedded. More than $50 \%$ glass shards; trace of magnetite. Lower contact gradational. Sample 322-1 .......

1. Conglomerate, pebble; calcareous cemented $\ldots \ldots \ldots \ldots \ldots \ldots \ldots 1$ Total estimated thickness $\ldots \ldots \ldots \ldots \ldots \ldots \ldots \ldots \ldots \ldots \ldots$

\section{LOCALITY 323. CROW CREEK}

$\mathrm{NE}_{4} \mathrm{NWW}_{\frac{1}{4} \mathrm{NE} \frac{1}{4}}$ sec. 32, T. 6 N., R. 1 E.; Broadwater County; west side of sma11 gully in bench on north side of creek. Oligocene sedimentary tuff unit of Klepper and others (1971, pp. 12-13, P1. 1). Strike north $70^{\circ}$ west and dip $20^{\circ}$ south.

Unit

Estimated

11tstone, clayey, tuffaceous/lithic tuff; pink1sh gray with white spots; medium hard, brittle; slope former. 2 foot thick layer 2 feet below top of unit contains 10\%-15\% white pumice granules up to $3 \mathrm{~mm}$ in diameter. Sample 323-1 .... 15

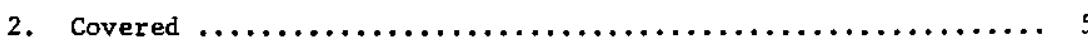

1. Siltstone, sandy; mottled pink and gray; medium hard to hard; ledge former $\ldots \ldots \ldots \ldots \ldots \ldots \ldots \ldots \ldots \ldots \ldots \ldots \ldots \ldots, 6$

Total estimated thickness

\section{LOCALITY 324. MILLIGAN CANYON ROAD EXIT NO. 1}

$\mathrm{SW}_{4} \mathrm{NE}_{\frac{1}{4}} \mathrm{NW}_{\frac{1}{4}}$ sec. 16, T. 2 N., R. 1 W.; Jefferson County; east side of reentrant. Climbing Arrow Formation of Robinson (1963, p. 69-77, P1. 1). Unit 5 is tentatively correlated with the uppermost units in localities 325 and 326 . Sandstone, pebbly; medium grained, poorly sorted; with sub-
rounded to subangular pebbles of 1gneous and metamorphic rocks. Locally characterfzed by anomalous radioactivity. Samples described below are from anomalously radioactive beds exposed in a prospect pit about 25 to 50 feet from the

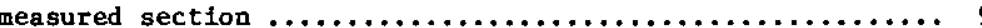

Sample 324-3. Sandstone, feldspathic to arkosic; moderate yellowlsh brown (weathers to medium brown); coarse grained, poorly sorted, with subangular grains; soft, friable (weathers to soft, loose); slope former; iron-stained; tabular even; Internally massive. Lower contact sharp, regular. Trace smokey quartz. Estimated thickness, 2 ft.

Sample 324-2. Iron oxide cemented contact between sandstone (sample 324-3) and claystone (324-1); moderate brown; medium hard, friable; ledge former; tabular even, internally parallel even, very thin to laminar bedding. Lower contact sharp, regular. Contains smokey quartz. Eatimated thickness $0.2 \mathrm{ft}$.

Sample 324-1. Claystone, silty; dusky yellow (weathers to light gray); medium hard, plastic (weathers to soft, loose); slope former; iron-stained along silty laminae; internally mostly massive. Not exposed in measured section. Estimated thickness, $3 \mathrm{ft}$.

\section{imated} hick. (ft) 
LOCALITY 324. (continued)

Claystone, sandy, micaceous; dark olive brown (less dark near top). Iron-stained at upper contact. Lower contact covered. 7

3. Sandstone, silty, pebbly; coarse grained, poorly sorted, with subrounded to angular pebbles. Lower contact covered ..... 27

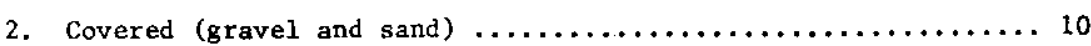

I. Sandstone, tuffaceous; white $\ldots \ldots \ldots \ldots \ldots \ldots \ldots \ldots \ldots \ldots \ldots$

Total estimated thickness

\section{LOCALITY 325. MILLIGAN CANYON ROAD EXIT No. 2}

$\mathrm{W}_{\frac{1}{2}} \mathrm{NW}^{1} / \mathrm{SE} \frac{1}{4} \mathrm{sec} .16$, T. 2 N., R. 1 W.; Jefferson County; near south end of prominent west-southwest-facing escarpment. Climbing Arrow Formation of Robinson (1963, pp. 69-77, Pl. 1). Strike north $6^{\circ}$ east and dip $4.5^{\circ}$ east. Unit 9 is tentatively correlated with the uppermost units of localities 324 and 326 .

Unit

Measured

thick. (ft) to light yellowish brown); coarse grained, poorly sorted, with subrounded to subangular grains; contains lenses of subrounded to angular pebbles; soft, loose; slope former; iron-stained, tabular even, channel; internally massive. Lower contact sharp, regular. Locally anomalously radio-

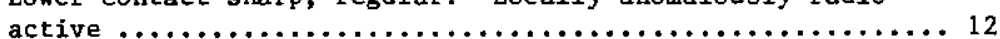

8. Claystone, sandy, pebbly, bentonitic; medium greenish brown (weathers to 1ight grayish brown); soft, frlable, (weathers to soft, loose); slope fortser; tabular even; internally massive. Lower contact sharp, regular. Anomalously radio-

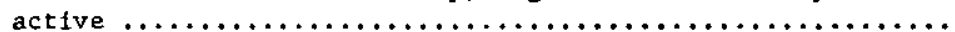

7. Sandstone, feldspathic; yellowish gray (weathers to light grayish brown); coarse to medium grained (fines upward), poorly sorted, with subrounded to subangular grains; soft, loose (weathers to soft, frtable); Iron-cemented at base; lentic channel. Lower contact sharp; irregular. Minor carbonaceous material and mica. Anomalously radioactive. Contalns meta-autunite and coffinite. Sample 325-4 representative of unit; Sample 325-5 from pale greenish yellow,

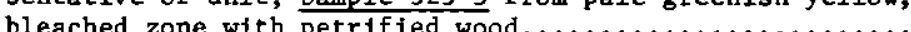

6. Claystone, sandy; moderate olive brown (weathers to medium reddish brown); soft, frangible (weathers to soft, loose): slope former; iron-stained near the top. Contains about $5 \%$ angular, medium to coarse-grained quartz sand; trace blotite. Anomalously radioactive. Sample 325-3 from near top ...... 3.7
LOCALITY 325. (continued)

$\frac{\text { Unit }}{5 .}$ Sandstone, silty, arkosic; dusky yellow (weathers to light orang1sh gray); medium grained, poorly sorted, with subrounded to subangular grains; soft, friable; (weathers to medium hard, friable); slope former; Iron-stained near top; medium hard, frlable); slope former; lronstalned near top; lentic chanel. Lower contact sharp, irregular. Minor blotite and smokey quartz. Sample 325-2 from near top, above

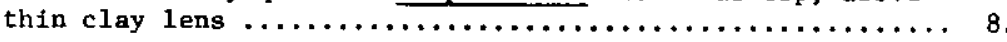

4. Claystone, sandy, bentonitic; moderate olive brown (weathers to medium gray) with $10-15 \%$ angular, medium to coarse grained quartz sand; soft, compact (weathers to soft, loose); slope former; lent1c; Internally massive. Lower contact sharp. Sample $325-1$ from near top ........................ 3.7

3. Sandstone, quartz; medium brown (weathers to light gray); medium to coarse grained, poorly sorted, with angular grains; soft, loose (weathers to medium hard, friable); slightly iron-stained near the top ; tabular even; internally massive. Lower contact sharp, regular. Minor biotite ................

2. Claystone, sandy; medium greenish brown (weathers to light gray); with less than $10 \%$ lenses of medium grained angular
quartz sand; medium hard, frangible (weathers to soft, loose); slope former; tabular even; internally massive .......... 13

1. Sandstone, pebbly and silty; medium brown (weathers to light brownish gray); medium grained, poorly sorted, with angular

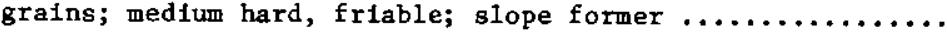

Total measured thickness

\section{LOCALITY 326. MILLIGAN CANYON ROAD EXIT No. 3}

$\mathrm{NW}_{\frac{1}{4}} \mathrm{SWl}_{4} \mathrm{SE}_{\frac{2}{4}}^{2} \mathrm{sec} .16$, T. 2 N., R. 1 W.; Jefferson County; 200 to 300 yards south of locality 325 . Hand level used to determine thickness. Climbing Arrow Formation of Robinson (1963, pp. 69-77, Pl. 1). Strike north 8.5 east; dip $4.5^{\circ}$ east. Unit 6 tentatively correlated with uppermost units of localities 324 and 325 . Units 2 thru 6 are anomalously radioactive.

Sandstone, feldspath1c; light gray (weathers to reddish gray); medtum to coarse grained, moderately sorted, with subangular grains; hard, brittle; ledge former; silica cemented; tabular even; Internal parallel thin beds; lower contact sharp, regular. Minor blotite and smokey quartz. Sample

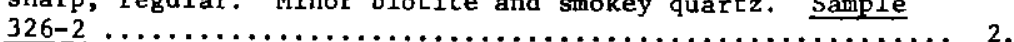


Estinated

Unit

Siltstone, sandy, tuffaceous; very pale orange; with poorly sorted, very fine to very coarse sand grains of quartz,
feldspar and pumice; soft, frlable; slope former; locally calcareous cemented; internally disturbed and irregular (exhibits penecontemporaneous drag folding induced by eastflowing current). Contains rounded pebbles of pumlce near base of exposure. Lower contact covered. Minor petrified

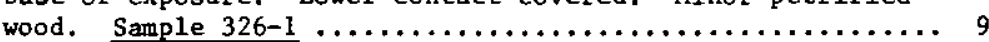

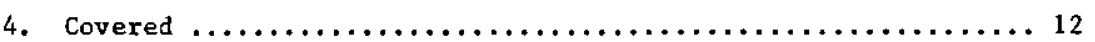

3. Sandstone, conglomeratic, volcanic (fines upward to tuffaceous siltstone); with pebbles of pumice .....................

2. Covered $\ldots \ldots \ldots \ldots \ldots \ldots \ldots \ldots \ldots \ldots \ldots \ldots \ldots \ldots \ldots \ldots, 2.5$

1. Sandstone, conglomerat1c, arkosic; yellowish gray (weathers to light gray); coarse to very coarse grained, moderately sorted, with rounded and subangular grains, with pebbles of volcanic rock $(75 \%+)$; medium hard, friable; cliff and ledge former; tabular even; internally very thin bedded with planar crossbedding. Sample $326-3 \ldots \ldots \ldots \ldots \ldots \ldots \ldots \ldots . . .6$

\section{LOCALITY 327. DEEP CREEK}

$\mathrm{N}_{2}^{1} \mathrm{SW}_{2} \mathrm{SE}_{\frac{1}{4}}$ sec. 30, T. 7 N., R. 3 E.; Broadwater County; on prominent nose, 200-300 yards east of residence on north side of U.S. HIghway 12 . Hand level used to determine thickness. Tertiary deposits mapped by Nelson (1963, PP. J41-J45, P1. I), whtch, according to Robinson (1967), are equivalent to the Miocene and Pliocene Sixmile Creek Formation. Strike north $37^{\circ}$ W.: dip $24.5^{\circ}$ E.

Unit

Estimated

Conglomerate, silty to sandy; very pale orange; calcareous cemented, degree of cementation variable. Most resistant near middle of unit; forms prominent ledges and cliffs. Upper 80-100 feet poorly cemented. Composition and shape of clasts similar to basal conglomerate of unit 2, but contains some clasts up to 6 Inches in diameter. Locally contains beds of massive claystone or siltstone up to 8 feet thick. Sample 327-2 taken from base of lowest cemented bed ........159.3

10. Claystone; grayish orange (weathers to light pinkish gray); soft, loose; slope former. Sample $327-1 \ldots \ldots \ldots \ldots \ldots \ldots 13.6$

9. Claystone, pebbly; slope former, but calcareous cemented near top to form isolated ledges and knobs. Pebbles simflar to those in unit $8 \ldots \ldots \ldots \ldots \ldots \ldots \ldots \ldots \ldots \ldots \ldots \ldots \ldots \ldots, 9$.

LOCALITY 327. (continued)

8. Conglomerate, flat pebble; ledge former; calcareous cemented. Similar to basal conglomerate of unit $2 \ldots \ldots \ldots \ldots \ldots \ldots .6$

7. Clay; medium reddish brown (weathers to 1 ight pinkish gray);

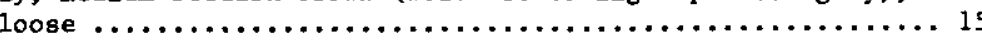

6. Conglomerate, flat pebble; calcareous cemented. Stmilar to basal conglomerate of unit 2 except pebbles are smaller .... 5.9

5. Siltstone, and claystone; light pinkish gray; soft; slope former; calcareous cemented. Contains medium thick ledge of former; calcareous cemented, Contains medium thick ledge of 63.7

4. Gravel, flat pebble; similar to basal conglomerate of unit 2,

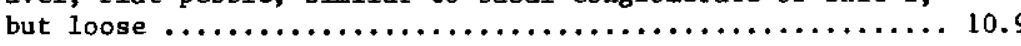

3. Claystone; fines upward from thin basal conglomerate similar to that of unit 2 thru 2.5 feet of siltstone to 14.3 feet of

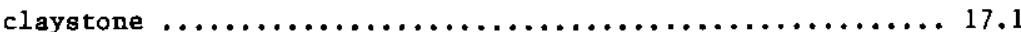

2. Siltstone and claystone (fines upward from medium thick basal flat pebble conglomerate which is calcareous cemented, claybound, and composed of Belt Series rocks thru thin bed of pebbly siltstone, to siltstone and claystone); 11ght pinkish gray; calcareous cemented $\ldots \ldots \ldots \ldots \ldots \ldots \ldots \ldots \ldots \ldots \ldots, 47.3$

1. Siltstone and claystone; light pink1sh gray; slope former; very calcareous; internally massive $\ldots \ldots \ldots \ldots \ldots \ldots \ldots \ldots . \ldots \ldots .7$

Total estimated thickness .369 .2

\section{LOCALITY 328. MAGPIE CREEK POINT}

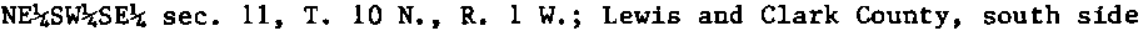
of prominent point which is on the southeast side of Magpie Creek. Section starts at a shear zone or fault at lake level and ends at the base of the older Quaternary gravels (Mertie and others, 1951, pp. 41 and 42, P1. 1). Hand-level used to estimate thickness. Tertiary unit 3 of Mertie and others (op. c1t., pp. 35-37, P1. 1). Tertiary rocks in the locality are of Lower Miocene age (Wh1te, 1954, p. 398, F1gs. 42 and 51). Unft thicknesses have been corrected, where appropriate, to compensate for net slip along a west-dipping normal fault that cuts the rocks of this section.

$\frac{\text { Untt }}{7 .}$

Estimated

Sandstone (fines upward to sandy siltgtone); light brown; fine grained, with angular grains; porous; unevenly bedded in lower 8 feet (cross-bedded channel scour in basal i foot), internally massive above lower $8 \mathrm{feet}$. Lower contact sharp,

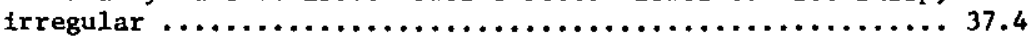




\section{LOCALITY 328. (continued)}

$\frac{\text { Unit }}{6 .}$

$\begin{array}{ll} & \text { Estimated } \\ \text { thick. (ft }\end{array}$ tigtone; light pinkish brown; very flne grained; ard, cliff former; porous; internally massive. Lower contact sharp, trregular. $85-95 \%$ glass shards $\ldots \ldots \ldots 14.8$

5. Siltstone or claystone, tuffaceous; white; soft, friable; Internally massive; composed of glass shards. Lower contact

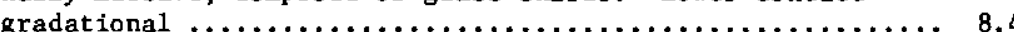

4. Siltstone, sandy (similar to unit 1); light brownish gray; internally massive; contalns trace of silicifled bones. Composed of reworked glass shards. Contains a 0.5 foot lens of very fine grained water laid ash. In upper 10-20 feet, unit coarsens, becomes lighter in color, and contain some lenses of medium and coarse grained sand ...........135

3. Claystone; light brown; soft to medium hard; slope former

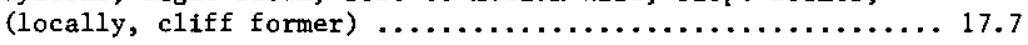

2. Sand, pebbly, ardosic; light ollve brown (weathers to medium brown); medium to coarse grained, moderately sorted, with subangular to angular grains; with pebbles of argillite $(80 \%+)$, welded tuffs, shales and quartzites; sof $t$, loose; slope former; iron-stained. Trace heavy minerals (biotite

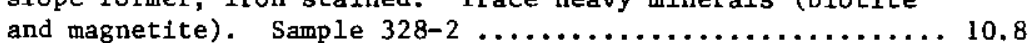

1. Siltstone, sandy; yellowish gray (weathers to medium reddish brown); with fine grained, poorly sorted, subangular to angular grains of sand; locally calcareous; cliff former; internally massive; contains glass shards. Sample 328-1. Unit coarsens near top to a slope-forming, poorly sorted, fine-grained quartz sandstone, with angular to subangular grains, that contains some glass shards and a minor amount of

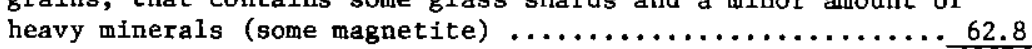

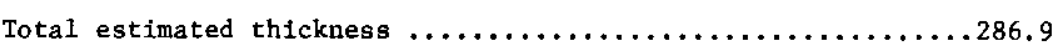

\section{LOCALITY 329. CAVE GULCH SOUTHEAST RIDGE}

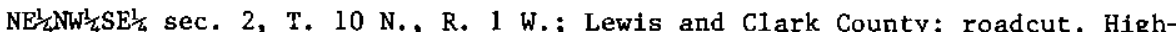
way 284, just northwest of top of ridge between Cave Gulch and Magpie Creek. Tertlary Unit 4 of Mertie and others (1951, pp. 37 and 38, P1. 1); Miocene or younger since it overlies Mertie's Unit 3 (see locality 328 ). or younger since it overlies Mertie's Unft 3 (see locality 328). Estimated

Conglomerate, silty shale; moderate brown (weathers to dark thick. (ft) pinkish brown); with angular flat pebbles of brown shale (70\%) and plink shale (25\%); medium hard, friable; cliff parallel even beds. Lower contact erosional (greater than

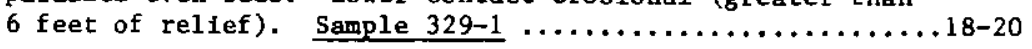

\section{LOCALITY 330. WINSTON BADLANDS No. 1}

$\mathrm{NE}_{4} \mathrm{SW}_{\frac{1}{4} \mathrm{NW} / \frac{1}{4}}$ sec. 20, T. 9 N., R. 1 E.; Broadwater County; Base of section located 400 feet at north $20^{\circ}$ east from break in slope at west end of inter fluve. Section ends at covered reentrant about $1 / 4$ mile northeast. Hand level used to est fmate thickness. Lower part of Tertiary unit 2 of oligocene age (Mertie and others, 1951, pp. 33-35, P1. 1 and 2) as mapped by Becraft (1958, pp. 153-159, Pl. 3). Average attitude: strike north $26^{\circ}$ west; dip of $28^{\circ}$ east. Although many anomalously radioactive localities in the Winston badlands were mapped and discussed by Becraft (ibid.), the on1y anomalous unit in this measured section is the lignite of unit 2 .

stimated

23. Clay, bentonitic; dark greenish brown $\frac{\text { thick. }(\mathrm{ft})}{7.3}$

22. Claystone, silic1fied $\ldots \ldots \ldots \ldots \ldots \ldots \ldots \ldots \ldots \ldots \ldots \ldots \ldots, 1.8$

21. Claystone, silty, bentonitic; dark greenish gray (weathers to

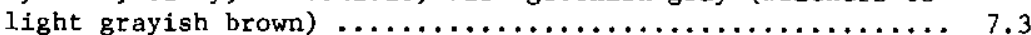

20. Siltstone; medium brown (whitish in top 2 feet); cliff former;

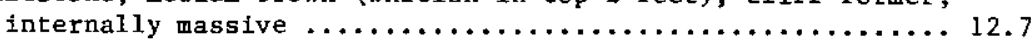

19. Claystone, bentonftic; slope former $\ldots \ldots \ldots \ldots \ldots \ldots \ldots \ldots 10.9$

18. Claystone; dark greenish brown; interbedded with 1 foot beds of silicified claystone. Cliff former. Basal 0.5 foot is medium gray siltstone $\ldots \ldots \ldots \ldots \ldots \ldots \ldots \ldots \ldots \ldots \ldots \ldots \ldots \ldots \ldots \ldots \ldots \ldots, 2$

17. Siltstone, conglomeratic, medium greenish brown (weathers to a yellowish gray). Pebbles of pumice in basal 3 feet ....... 9.1

16. Sandstone, tuffaceous; light gray; with medium to coarse grains

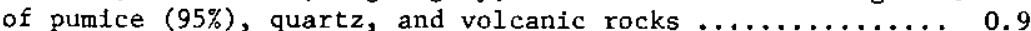

15. Siltstone and claystone, tuffaceous; medium brown, very slightly

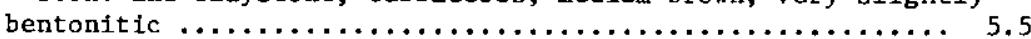

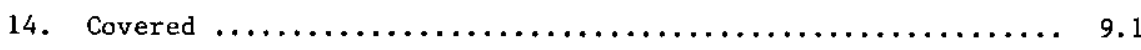

13. Siltstone, tuffaceous; medium yellowish brown. Capped by 2 inches of silicified siltstone that overlies 3 inches of coarse grained, white, resistant sandstone composed of

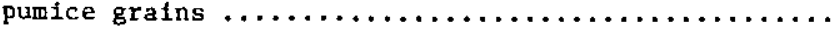

12. Claystone or siltstone, tuffaceous; hard; ridge former.

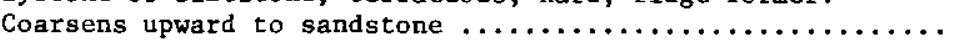

11. Sandstone, tuffaceous; light yellowish gray; fine to medium grained; medlum hard. Predominately composed of sand-slzed

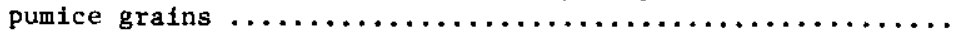

10. Siltstone, sandy; light yellowlsh gray; grades upward into a mediut greenish brown silicified claystone ............... 3.0 
Estimated thick. $(f t)$

$\frac{\text { Unit }}{9 .}$

Sandstone, conglomerate, claystone (all interbedded); light gray; internally very thin bedded; all composed of appropriate

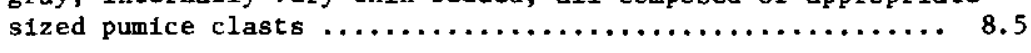

8. Clay, bentonitic; medium brown (weathers to medium gray) $\ldots . .6 .8$

7. Sandstone, conglomeratic; medium gray; medium to coarse grained, with angular grains of quartz $(50 \%)$, pumice $(25 \%)$ and lithic clasts $(25 \%)$, and pebbles of volcanic rocks and pumice; ledge former; permeable; cross bedded; fines upward to medium grained sandstone. Contains some very thin lenses of

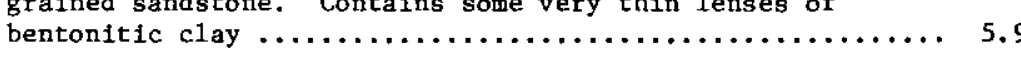

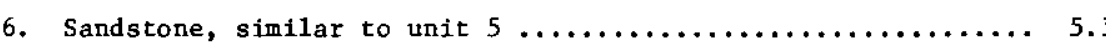

5. Sandstone; weathers medium yellowish gray; medium grained; some bentonitic clay lenses; pebbles of volcanic rock scattered throughout. Basal $0.7 \mathrm{feet}$ is white and is composed of

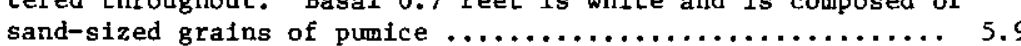

4. Sandstone, clayey, tuffaceous; medium brown to medium orangtsh brown; medium grained; composed of sand-sized punice grains. Varies from clayey sandstone to bentonitic sandy claystone.. 5.9

3. Sandstone, puniceous; grayish yellow; composed of well sorted, medium to coarse grained, subangular to subrounded grains of pumice $(90 \%)$, and medium grained, angular quartz, biotite and lithic clasts (10\%); medium hard, friable; ledge former; and Iithic clasts $(10 \%)$; medium hard, friable; ledge former;
porous; iron-stained. Sample 330-4. Unit overlies a very thin layer of banded chalcedony, which overlies a bentonitic

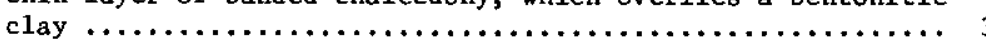

2. Sandstone (65\%), clayey (gradational with claystone), slightly bentonitic; medium yellowish green (weathers to light yellowish gray); composed of medium-sand-sized grains of pumice in ish gray); coposed of mediumsand sized grants of pumce a clay matrix; grades vertically within beds to claystone without pumice grains; soft; slope former. Lower contacts are sharp, regular. Becomes more bentonitic and contains larger proportion of clay in beds up-section in the unit. Bed thickness averages 7.5 feet and ranges from 2 to $15 \mathrm{feet}$.

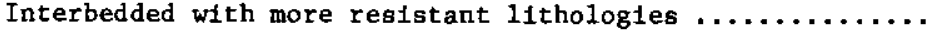

Sandstone $(30 \%)$, pebb1y, tuffaceous; white (weathers to very pale orange); medium to coarse gra1ned; composed of subrounded medium sand to pebble-sized clasts of pumice (locally contains grains of quartz and biotite) in a tuffaceous matrix; hard to medium hard; ledge former. Thickness averages 2 feet and ranges from 0.5 to 7 feet (thickest near base of unit).

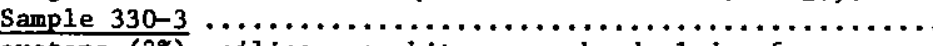

Claystone (2\%), siliceous; white; very hard; ledge former; silica cemented; locally lron-stafned; locally carbonaceous.

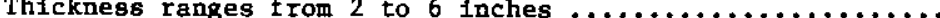

LOCALITY 330. (continued)

Unit

Sandstone (2\%), siliceous; medium sized grains of pumice

Estimated

(90\%) and quartz (10\%); very hard; ledge former; sillceous cemented, impermeable. Thickness ranges from 2 to 8 inches.

Lignite (1\%); moderate brown; anomalously radioactive; 1 to 3

inches thick, grades down into a 2 inch thick light tan carbonaceous shale. Persists about 300 feet laterally. One bed only, located 10 to 15 feet above base of unit. Sample

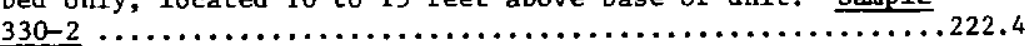

1. Clay, bentonitic; dark greenish brown (in. lower 70 feet) to medium reddish brown (appear 130 feet); medium hard, plastic (weathers to soft, loose); internally massive. Trace gypsum crystals, both as plates up to 3 inches in diameter and as needles. Lower $70 \mathrm{feet}$ contains rounded pebbles of pumfce. needles. Lower 70 feet contalns rounded pebbles of pumice. ledge-forming quartz sandstone. The lenses range from 0.5 to 1.5 feet thick, and are separated by 5 to 15 feet of claystone. The frequency and thickness of the sandstone lenses increase up section. Sample 330-1 taken of the acicular

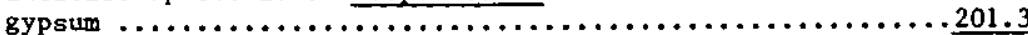

Total estimated thickness

\section{LOCALITY 331. EAST SIDE GOON HILL}

$\mathrm{N}_{2}^{2} \mathrm{NE}_{4} \mathrm{~J}_{4} \mathrm{SW} \frac{1}{4}$ sec. 3, T. $10 \mathrm{~N} .$, R. 1 W.; Lewis and Clark County; at water level next to Highway 284 at the south end of the inlet. Although Mertie and others (1951, P1. 1) map these rocks as their Tertiary Unit 3 (pp. 35-37), the outcrops appear lithologically similar to their Tertiary Unit 2 (pp. 33-35). A lower Oligocene age is assigned to this locality by white (1954, p. 396, Fig. 40 and 51).

\section{$\frac{\text { Unit }}{4 .}$}

stimated thick. $(\mathrm{ft})$

3. Sandstone (fines to sandy and clayey siltstone in upper 3.5 feet), tuffaceous; pale greenish yellow; composed of moderately sorted, medium to coarse grained, subangular to subrounded grains of pumice. Sample $331-1 \ldots \ldots \ldots \ldots \ldots \ldots .6 .5$

2. Sandstone (fines upward to siltstone), quartz; greenish brown, medium grained, with subangular grains $\ldots \ldots \ldots \ldots \ldots \ldots \ldots 6$

1. Claystone, slightly bentonitic; medium yellowish brown; with rounded pebbles of siltstone or claystone. Becomes increasIngly sandy in upper 2 feet. Lies unconformably on the preTertiary rocks that make up Goon Hill, and contains fragments of these rocks in the lower 2 feet of the unit $\ldots \ldots \ldots \ldots \ldots$

Total estimated thickness $\ldots \ldots \ldots \ldots \ldots \ldots \ldots \ldots \ldots \ldots \ldots . \ldots \ldots$ 


\section{LOCALITY 332. EAST HELENA SUBSTATION}

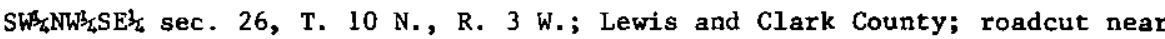
power substation on U.S. Highway 12. Oligocene "Lake Beds" of Lorenz and Swenson (1951, PP. 16-18, P1. 1). Strike north $66.5^{\circ}$ west; dip $8^{\circ}$ north.

Unit

Measured

6. Siltstone; (lower 1 foot is poorly sorted, medium grained, white, tuffaceous sandstone); medium yellowlsh brown (weathers to 1 ight gray); soft, loose; slope former; tabular uneven; Internally massive. Lower contact gradational........... 3

5. Sandstone, tuffaceous; light gray (weathers to light brownish gray); medium grained, moderately sorted, with angular grains; soft, friable; ledge former; permeable; tabular uneven; Internal parallel uneven thin beds. Lower contact

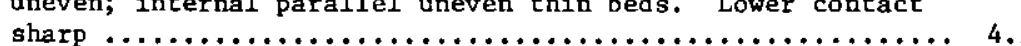

4. Siltstone, sandy, tuffaceous (top $1 / 2$ bentonitic); upper $1 / 2$ banded yellowish gray, lower $1 / 2$ banded light orangish brown; with subangular sand grains; soft, loose (weathers to medium hard, friable); iron-stained in lower one-half; tabular even; internally massive. Lower contact gradational. 9

3. Conglomerate, sandy, pumiceous; banded yellow and white (weathers to light yellowish gray); with angular pebbles of pumice $(90 \%)$ and volcanic rocks $(10 \%)$, in a matrix of poorly sorted, medium to very coarse grained, pumiceous sandstone; soft, frlable, very lightly iron-stained; tabular even; internal parallel uneven thin to very thin beds. Lower contact erosional (less than one foot relief). Sample 332-1 ..... 5.7

2. Siltstone, conglomeratic; dark orange; with subangular pebbles of unit 1 in lower 1/3; medium hard, compact; iron-stained tabular uneven; internally medium bedded. Lower contact

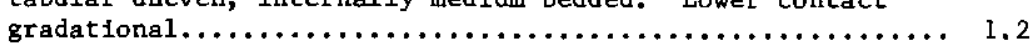

1. Sandstone, conglomeratic, tuffaceous; light greenish white (weathers to light gray); very fine to very coarse grained, very poorly sorted; with subangular pebbles of pumice (95\%) and dark volcanic rocks (5\%); medium hard, friable; upper 2 feet slightly iron-stained; tabular even; internally

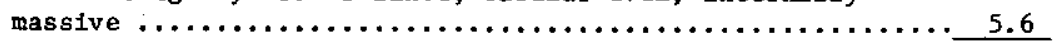

Total measured thickness 29

\section{LOCALITY 333. KETTLE HOLLOW}

SW $\frac{1}{4} \mathrm{SW}_{\frac{1}{4}} \mathrm{SE}_{\frac{1}{4}}$ sec. 17 , T. 11 N., R. 4 E.; Meagher County; just west of road, on barely perceptible, northeast-trending low ridge. Mapped as Miocene tuffs by Birkholtz (1967, pp. 26-28, P1. 1).

\section{LOCALITY 333. (continued)}

Unit

1. Tuff, lapillf, bentonitic; medium yellowish gray with pink spots (weathers to light yellowish gray); soft, friable; slope former; porous. Composed of bentonized pumfceous lapilli and ash (95\%) and subangular pebbles of a black volcanic rock $(5 \%)$.

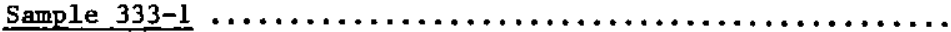

\section{LOCALITY 334. NORTH OF BEAVER CREEK}

SW $1 \mathrm{NWW}_{4} \mathrm{NWW} / 4$ sec. 25, T. 12 N., R. 4 E.; Meagher County; east of road in adjacent drainageway. Mapped as Tertiary sedimentary rocks by Hruska (1967, pp. 48-51, P.. 1); probably equivalent to the Fort Logan Formation of Koerr (1939, as per Hruska, p. 49). Lithology not characteristic of Tertiary sediments in the Smith River Valley.

stimated

1. Sandstone, conglomeratic feldspathic; (ft) to pinkish gray); medium grained; moderately sorted, with angular grains; contains subrounded pebbles of siltstone (50\%), Belt Series rocks (45\%), and felsic igneous rocks (5\%); hard, brittle; ledge former; channel; internally thin to very thin bedded with cross-bedding. Sample 334-1 ..... 4-5

\section{LOCALITY 335. SOUTH OF SHEEP CREEK No. 1}

$\mathrm{S}_{\frac{1}{2}} \mathrm{SW}_{\frac{1}{4}} \mathrm{SW}^{\frac{1}{4}} \mathrm{sec}, 18$, T. $12 \mathrm{~N}$., R. 5 E.; Meagher County; roadcut. Mapped as Tertiary alluvium of Mlocene age by McClernan (1969, pp. 26-27, P1. 1). Strike north $40^{\circ}$ west; dip $2.5^{\circ}$ east.

Measured

$\frac{1}{6 .}$ Siltstone; medium yellowish brown; slope former............... 9.2

5. Siltstone, tuffaceous; slope former. Contains pumice clasts ranging from coarse sand to pebble size............... 23

4. Sandstone, silty and conglomeratic; medium gray (weathers to medlum orangish brown; medium grained, very poorly sorted, with pebbles of pumice; ledge former; porous ........... 2

3. Siltstone, micaceous; medium brown; medium hard; slope former slightly calcareous. Subordinate mica in lower 2 feet..... 8

2. Lithic-vitric tuff/tuffaceous sandstone; grayish yellow (weathers to medtum gray); very coarse grained, poorly sorted, with subangular grains of pumice; medium hard, friable; slope former; porous; banded with iron-stalning 2 to 4 feet above base; tabular even; internal parallel even, medium beds. Lower contact sharp. Minor smokey bipyramidal quartz. Sample 335-2 


\section{LOCALITY 335. (continued)}

Siltstone, tuffaceous; grayish orange (weathers to light gray) soft, brittle; slope former; permeable; internally massive. Contains $<5 \%$ very coarse grained, subrounded grains of pumice

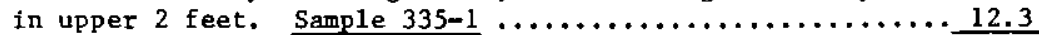

Total measured thickness $\ldots \ldots \ldots \ldots \ldots \ldots \ldots \ldots \ldots \ldots \ldots \ldots \ldots .8$

\section{LOCALITY 336. SOUTH OF SHEEP CREEK No. 2}

NE $\frac{1}{4} \mathrm{SE}_{\frac{1}{4} \mathrm{NE}} \frac{1}{4}$ sec. 24, T. $12 \mathrm{~N}$, , R. 4 E.; Meagher County; roadcut. Mapped as Tertiary allumium of Miocene age by McClernan (1969, Pp. 26-27, P1. 1). Strike north $65^{\circ}$ west; dip $4^{\circ}$ south. Lithologically similar to unit 2 of locality 335.

Estimated

Lithic-vitric tuff/pumice conglomerate; pale greenish yellow (weathers to medium grayish brown); with subrounded to subangular pebbles of pumice in a matrix of poorly sorted, very coarse grained, pumiceous sandstone; soft, friable; slope former; permeable; tabular even; internal parallel even medium to thick beds. Lower contact sharp. Containg localized 1ntergranular concentrations of soft, powdery, black, organic(?) material and a trace of smokey, bipyramidal quartz

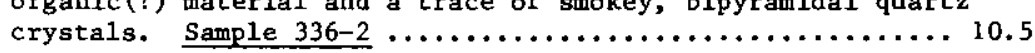

1. Lithic-vitric tuff/pumiceous sandstone; dark yellowish orange (weathers to moderate yellowish brown); coarse to very coarse grained, poorly sorted, with subangular to subrounded grains and pebbles of pumice; soft, friable; slope former; heavily 1ron-stained; tabular even; internally masalve. Trace smokey, bipyramidal quartz crystals. Sample 336-1 $\ldots \ldots \ldots 4$

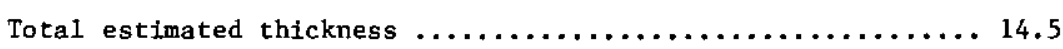

\section{LOCALITY 337. HIGHWAY 12 SPRING}

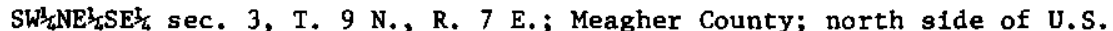
Highway 12. Water sample 337-1 from spring. Water probably rising from pre-Tertiary rocks.

\section{LOCALITY 338. HANSON'S SPRING}

$\mathrm{N}_{\frac{2}{2}} \mathrm{SW}_{\frac{1}{4}} \mathrm{NE}_{\frac{1}{4}} \mathrm{sec} .34, \mathrm{~T} .10 \mathrm{~N} ., \mathrm{R} .6 \mathrm{E}$.; Meagher County; spring (water sample 338-1) in the bottom of a drainageway cut in Tertiary sediments mapped by Groff (1965, p. 20, P1. 1) and Phelps (1969, pp. 27-28, P1. 1).

$\frac{\text { Unit }}{2 .}$ Siltstone, sandy and pebbly; light brown; calcareous ......... $\frac{\text { Estimated }}{6}$

\section{LOCALITY 338. (continued)}

Unit

1. Conglomerate, with angular to subangular pebbles and cobbles

Estimated

thick. ( $\mathrm{ft}$ )

of 1imestone (95\%) and Belt serles rocks (5\%); in a

calcareous cemented matrix; non-permeable $\ldots \ldots \ldots \ldots \ldots \ldots .8 .5$

Total estimated thickness

14.5

\section{LOCALITY 339. STOYONOFF LAKE}

$\mathrm{NE}_{\frac{1}{4}} \mathrm{SW}_{\frac{1}{4}} \mathrm{SW} / \frac{1}{4} \mathrm{sec} .20$, T. 11 N., R. 4 E.; Meagher County; low hill just north of lake. Mapped as Miocene tuffs by Birkholtz (1967, Pp. 26-28, P1. 1). Strike north $10^{\circ}$ west; dip $4^{\circ}$ east. Hand level used to estimate thickness.

$\frac{\text { Untt }}{4 .}$ Estimated thick. (ft)

4. Siltstone, similar to unit 2, but the pumice clasts are coarse sand-sized and make up less than $2 \%$ of the rock .......... 13

3. Conglomerate, sandy, limestone; yellowish gray; with angular to subangular pebbles (and some cobbles) of limestone (85\%), quartzite, sandstone, and siltstone, in a matrix of medium grained 1ithic sandstone; calcareous cemented; channel. Lower contact sharp, and erosional (15-20 feet relief). Locally contains thin lenses of sandstone. Sample 339-I ... 7

2. Siltstone; medium brown; slope former; locally calcareous cemented (1-2 foot thick beds); internally massive where not cemented. Slightly bentonitic. Locally conglomeratic with pebbles of pumice $\ldots \ldots \ldots \ldots \ldots \ldots \ldots \ldots \ldots \ldots \ldots \ldots \ldots$

1. Conglomerate $(50 \%)$, sandy; with angular to subangular pebbles of limestone $(90 \%+)$, siltstone, and sandstone; in a matrix of coarse to medium grained sandstone; ledge former; calcareous

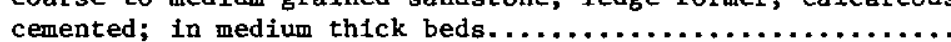

Siltstone (50\%), medium brown; in medium thick beds. In a few places, loose to well cemented, coarse sandstone is interbedded with the conglomerate, instead of siltstone......... 18

Total estimated thickness .121

\section{LOCALITY 340. LITTLE ANTELOPE CREEK}

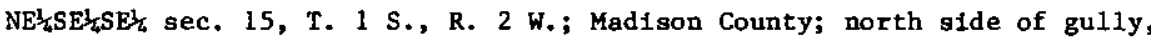
about 20-30 feet west of line between sections 14 and 15 . Mapped as Tert1ary "Lake Beds" by Berry (1943, p. 22, P1. 1).

Sandstone, pebbly, feldspathic; yellowish brown (weathers to thick. (ft) dark gray); medium to coarse grained, poorly sorted; soft, friable; ledge former: iron cemented and stained; tabular even; internal parallel even bedding. Sample $340-1 \ldots \ldots .5$ 
NWE 4 NE $\frac{1}{4}$ NE $\frac{1}{4}$ sec. 23, T. 1 S., R. 2 W.; Madison County; small barrow p1t just north of old road bed of Highway 359. Mapped as Tertiary "Lake Beds" by Berry (1943, p. 22, P1. 1); may be equivalent to the coarse, basin-edge facies of the Climbing Arrow Formation of Robinson (1963, pp. 69-77, P1. 1).

$\frac{\text { Unit }}{2 .}$

\section{Estimated}

thick. ( $\mathrm{ft}$ )

2. Sandstone, conglomeratic, feldspathic; pale greenish yellow (weathers to medium brown); very coarse grained, poorly sorted; with subrounded pebbles of felsic igneous rocks (65\%), smokey quartz (30\%), and feldspar; lower 2 feet soft, loose, slope former; upper 2 feet hard, brittle, ledge former; upper 2 feet silica cemented; lentic channel; internal trough cross-bedding. Lower contact erosional (greater than 1 foot relfef). Trace of magnetite, biotite, and pink garnet. Minor smokey quartz. Sample 341-4 of soft, loose material; sample $341-5$ of silicified material ....... 4

1. Sandstone, locally pebbly, feldspathic; light yellowish gray; medium to very coarse grained, moderately sorted, with angular grains, with pebbles of smokey quartz (95\%) and feldspa (5\%); soft, frtable; slope former (locally silica cemented; hard, brittle; ledge former); lentic channel; internally trough cross-bedded. Trace magnetite and pink garnet; trace of silfcified wood partially replaced with secondary urantum minerals (carnotite). Sample 341-1 of petrifled wood. Sample $341-2$ of soft, friable material; sample $341-3$ of siliclfled material $\ldots \ldots \ldots \ldots \ldots \ldots \ldots \ldots \ldots \ldots \ldots \ldots \ldots, 8,9$

Total estimated thickness $12-13$

\section{LOCALITY 342. BEALS SECTION}

NWl $\mathrm{NWW}_{4} \mathrm{NE}_{\frac{1}{2}}$ sec. 23, T. 1 s., R. 2 W.; Madison County; north side of old road bed of Highway 359 , in large reentrant about 200 yards east of the raflroad. Mapped as Tertiary "Lake Beds" by Berry (1943, p. 22, P1. I); may be equivalent to the coarse, basin-edge facies of the climbing Arrow Formation of Robinson (1963, pp. 69-77, PI. 1). Strike north $10^{\circ}$ west; dip $9^{\circ}$ west.

to light brown); with subrounded pebbles of quartz $(45 \%)$ feldspar (45\%), and granitic rocks (10\%), in a matrix of moderately to poorly sorted, medium to very coarse grained sandstone; hard, brittle (soft, friable where uncemented); ledge former (slope former where uncemented); silica cemented (25\%) uncemented); tabular uneven; internally thin bedded with planar cross-bedding. Lower contact sharp, irregular. Trace magnetite, biotite, and pink garnet. Silicified beds make up $75 \%$ of unit and range in thickness from 2 to 5 feet thick. Uncemented beds range in thickness from 0.5 to 1.5 feet thick. Unit becomes less conglomeratic upward. Sample

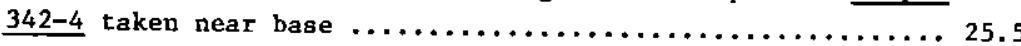

Unit

Siltstone (coarsens to fine sandstone in upper 5-10 feet), tuffaceous; light yellowish gray; soft, friable or loose slope former; tabular uneven; Internally massive. Contains some pebbly lenses. Lower contact covered. Minor biotite. Sample $342-3$ taken in fine sand near top ................. 33.2

Sample 342-5 taken of very hard, brittle, black to greenish yellow, radioactive silicified wood; probably from this unit. The greenish-yellow part consists of dominant copper and silican, subordinate aluminum and calcium, with minor tron.

3. Sandstone, feldspathic; medium to very coarse grained, poorly sorted, with subangular grains; internally cross-bedded. $75 \%$ light gray to 1ight greenlsh gray; soft, loose; slope former, permeable. 25\% Iight greenish gray (weathers to dark reddish gray); hard, brittle; ledge former; silica cemented.

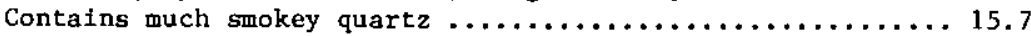

2. Siltstone, tuffaceous; light yellowish gray; soft, friable; slope former; porous; tabular uneven; Internally massive (except upper 2.5 feet which is very thin to thin bedded). Lower contact sharp, irregular. Predominantly silt-sized glass shards. Trace of plant remains. Sample 342-2 ...... 14.2

1. Sandstone, feldspathic; light gray and streaked with iron oxide; medium grained, moderately sorted, with subangular grains; soft, friable; slope former; permeable; 1ron-stained; lentic channe1, internally massive. Trace of magnetite, biotite,

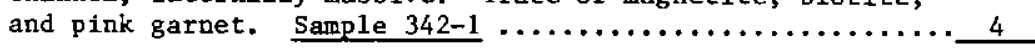

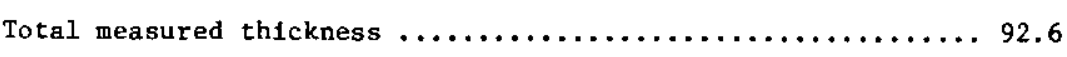

\section{LOCALITY 343. WILSON PARK ROAD}

$\mathrm{N}^{2} / 2$ sec. 26, T. $3 \mathrm{~N}$, , R. 3 W.; Jefferson County; $1 / 2$ mile south of wilson Park Road and $1 / 2$ mile north and northwest of buildings along east side of section 26. Units 2,3 , and 4 described below probably correspond to units 3,2 , and 1 , respectively, of measured section number 16 of Alexander (195: p. xxiii). Alexander constders the rocks in this section to be of Miocene age (pp. 74-79, xxi1t).

Siltstone (75\%), sandy, tuffaceous; very pale orange; with subangular, medium to coarse grained, lithic sand grains; medium hard, compact; slope former; locally calcareous cemented; tabular even; internally massive. Lower contact gradational. Predominately glass shards. Sample 343-2 from middle ..... Conglomerate (25\%), silty; medium light gray; with subrounded pebbles of dark gray volcanic rocks in a brown matrix of silt or poorly sorted very fine sand; soft, loose; slope former; lentic channel; internally thin bedded with trough cross-bedding. Lower contact sharp, irregular. Minor magnetite. occurs in lenses up to $6 \mathrm{ft}$ thick. Sample 343-3 from middle. $\star 100$ 
LOCALITY 343. (cont1nued)

Unit

Not described

2. Siltstone $(90 \%+)$, sandy; medium pinkish brown; medium hard

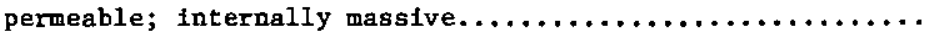

Sandstone (10\%-), arkosic; pale yellowish brown; coarse grained, moderately to well sorted, with subangular grains; soft, loose; slope former; medium thick; tabular even; internally massive. Lower contact sharp. Trace magnet1te, and amphi-

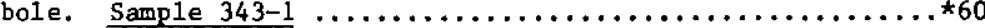

1. Sandstone (75\%); 1ight gray to very light salmon pink; very

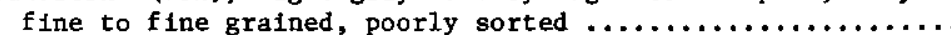
siltstone (15\%); light pinkish brown. Slightly bentonitic.

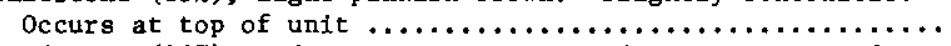
Sandstone $(10 \%)$; medium to coarse grained. Occurs as medium

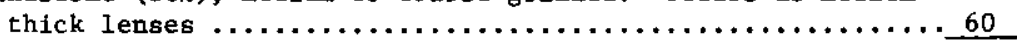

Total estimated thickness $\ldots \ldots \ldots \ldots \ldots \ldots \ldots \ldots \ldots \ldots \ldots \ldots$. . . . . .

*Thickness from Alexander (1955, p. xxiif).

\section{LOCALITY 344. DRY COTTONWOOD CREEK}

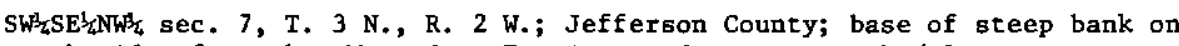
north side of creek. Mapped as Tertlary sedimentary rock (0ligocene or younger) by Weeks (1974). Unconformably overlain by 10 to 15 feet of late Tertiary or Quaternary gravel.

Unit

Conglomerate, pebble; soft, loose; slope former; Internally thin bedded with trough cross-bedding. Lower contact erostonal with about 1 foot rellef $\ldots \ldots \ldots \ldots \ldots \ldots \ldots \ldots \ldots, 6,7$

1. Sandstone, feldspathic; light grayish orange; medium to very coarse grafned, poorly sorted, with subangular grains; soft, loose; slope former; lentic bed; internally trougb cross-bedded. Minor magnetite and biotite. Contains clay balls up to 2 inches in diameter. Sample 344-1 $\ldots \ldots \ldots \ldots .8$

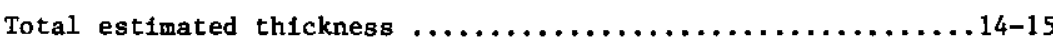

\section{LOCALITY 345. WILLOW SPRINGS WATER SAMPLE}

$\mathrm{NW}_{4} \mathrm{NWW}_{4} \mathrm{SE}_{\frac{1}{4}}$ sec. 16, T. 4 N., R. 2 W.; Jef ferson County; water sample 345-1. Water rises from sediments mapped as Oligocene and Mlocene tuff and grave by Rlepper and others (1957, p. 42, P1. 3).

\section{LOCALITY 346. NEW NEGRO HOLLOW ROAD}

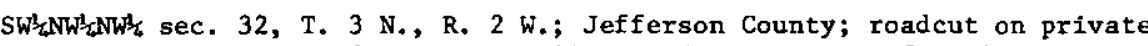
road which runs south from Negro Hollow Road, fust east of Boulder River. Mapped by Richard $(1966$, P1. 1) as the Bozeman group of Tertiary age.

$\frac{\text { Unit }}{2}$

Estimated thick. (f,t)

Siltstone, pebbly; yellowish gray (weathers to light brownish gray); soft, brittle; slope former; permeable; internally massive. Lower contact covered. Trace of silicified bone massive. Lower contact covered. Trace of silicified bone

1. Sandstone, conglomeratic, arkosic; grayish orange and streaked with iron-staining; very coarse grained, poorly sorted, with subangular pebbles; soft, friable; slope former; permeable; lentic channel; internally laminated to very thin bedded with trough cross-bedding. Trace of petrified wood and a few clay balls. Minor magnetite. Trace of biotite and horn-

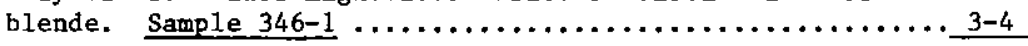

Total estimated thickness .9-12

\section{LOCALITY 347. DOHERTY MOUNTAIN}

SW $\frac{1}{2} \mathrm{NE}_{\frac{1}{2}}^{\frac{1}{4} S E \frac{1}{4}}$ sec. 7, T. 2 N., R. 2 W.; Jefferson County; at head of northwest draining valley. Bozeman group of Richard (1966, P1. 1); early Oligocene age (Alexander, 1955, p. 76). Strike north $54^{\circ}$ west; dip $11^{\circ}$ north.

Unit

Measured

8. Siltstone; medium yellowish brown; soft, loose; slope former; ick. $(\mathrm{ft})$ tabular even. Lower contact sharp $\ldots \ldots \ldots \ldots \ldots \ldots \ldots \ldots, 8.6$

7. Sandstone (50\%); medium gray; fine to medium grained, moderately sorted; soft, loose; slope former; tabular even. Lower contact sharp. Parallel even very thin beds of sandstone are interbedded with very thin beds of ash. Sand predomin-

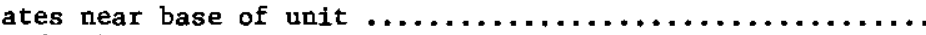
Ash (50\%); light yellowish gray; soft, loose; slope former. Interbedded with sandstone. Ash predominates near top of

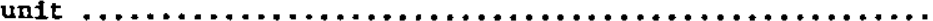

6. Claystone, sandy; yellowish white; soft, frangible; slope former; tabular even. Lower contact sharp ............. 3.7

5. Claystone, bentonitic; medium yellowish brown; with pebbles of pumice and volcanic rocks; soft, brittle; slope former ..... 1

4. Sandstone, conglomeratic; medium gray; medium to very coarse grained, poorly sorted; with angular pebbles of volcanic rocks (95\%), soft; slope former (lower 2 feet locally silica cemented; ledge former); tabular even; internal parallel even beds. Lower contact sharp ...................... 
Measured

Unit andstone (pebbly near base, fines in upper 2 feet to claystone); medium gray; coarse gralned; soft, loose; slope former; clay matrix; tabular even; Internal parallel even beds. Lower

contact gradational .............................6.

2. Sandstone (70\%), conglomeratic, tuffaceous; very light gray; fine grained, very poorly sorted, with rounded pebbles and sand grains of pumice in a tuffaceous matrix; medium hard, frlable; cliff former; porous; tabular even; internal thin to laminated, parallel even beds. Lower contact gradational.

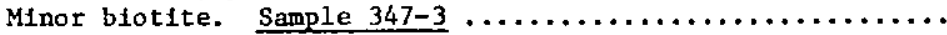

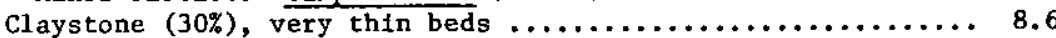

1. Claystone (55\%); varous beds are dark gray, medium greenish brown, dark brownish green, medium green, or pink; locally sandy, micaceous, or tuffaceous. Beds range from 0.5 to 5.7 feet thick. Sample 347-1 of claystone, sandy; grayish olive (weathers to light gray); with medium-size, angular grains of volcanic glass, quartz, feldspar and biotite; medium hard, brittle (weathers to soft, loose); slope former; tabular even; internally massive; from near contact with sandstone of

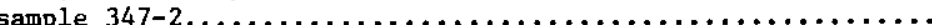

andotone (45\%); light yellowish brown, light gray, or medium greenish yellow; medium to very coarse grained, poorly sorted, with angular grains. Locally silty, pebbly, iron-stalned. with angular grains. Locally stlty, pebbly, lron-stanged from 0.5 to 5.1 feet. Sample $347-2$ of sandstone, subfeldspathic; dusky yellow (weathers to light gray); medium grained, poorly sorted, with angular grains; soft, loose; slope former; very slightly iron-stained; tabular even; internally massive; lower contact sharp; contains sand-sized grains of pumice and some clay balls; minor biotite .............. 39.6

Total measured thickness ........................ 83.4

\section{LOCALITY 348. SOUTHWEST NEGRO HOLLOW}

$\mathrm{SE}_{4} \mathrm{NWW}_{4} \mathrm{NE}_{\frac{1}{4}} \mathrm{sec} .5$, T. 2 N., R. 2 W.; Jefferson County, north wall of guIly. Hand-level used to estimate thickness. Mapped as Bozeman group of Tertiary age by Richard (1966, Pl. 1); probably of Miocene age (Kay and Fie1ds, 1958, p. 14 , see Stop 2 ). Strike N. $17^{\circ}$ west; dip $10^{\circ}$ east.

Siltstone (97\%), sandy (1ocally pebbly), tuffaceous; pale orange (weathers to light orangish brown); with medium to very coarse grained sand; medium hard, frlable; cliff former; porous; locally very lightly iron-stalned; tabular even; internal parallel even thick beds. Lower contact covered. Predominantly silt-sized glass shards. Sample $348-1 \ldots \ldots$.

\section{LOCALITY 348. (continued)}

Untt

Sandstone (3\%), silty, feldspathfc; pale yellowish brown with medium orangiah brown bands of iron-staining; coarse to very coarse grained, poorly sorted, with subangular grains; medium hard, frlable; slope former; porous; iron-stained; lentic channel; internal parallel even very thin beds. Lower contact sharp; upper contact gradational with sandy siltstone. Trace of magnetite and blotite. Contains zones wherein the sand grains are coated with black iron or manganese oxides. Sandstone typically occurs as lenses 2 to 3 feet thick and 20 to 40 feet wide. Sample $348-2 \ldots \ldots 20$

\section{LOCALITY 349. OLD NEGRO HOLLOW ROAD}

SE $\frac{1}{2} \mathrm{NW}_{4} \mathrm{SE} / \frac{1}{4}$ sec. 28, T. 3 N., R. 2 W.; Jefferson County; in reentrant on south side of bench north of road. Mapped as Bozeman group of Tertiary age by Richard (1966, P1. 1); Miocene age (Kay and Fields, 1958, p. 14, see stop 2). Strike N. $45^{\circ}$ east; dip $13^{\circ}$ W.

$\frac{\text { Unit }}{2}$

Estimated

2. Siltstone (55\%), conglomeratic; similar to conglomeratic siltstone of unit 1 , but contains more sand and pebbles; thin to medium bedded; slightly calcareous. Thickness ranges from 10 to 20 feet.

Sandstone (25\%), conglomeratic; similar to conglomeratic sandstone of unit 1 , but is more tabular. Occurs most frequently in lower half of unit. Up to 6 feet thick.

Sandstone (15\%), silty; similar to silty sandstone in unit 1 .

Conglomerate (5\%); with cobbles of limestone $(95 \%)$; hard, brittle; ledge former; calcareous cemented. 0ccurs as two 3 to 4 foot thick beds in upper 40 feet of unit ...........150-200

1. Siltstone $(90 \%)$, conglomeratic; light grayish orange; with angular pebbles of quartz (50\%), and granite (40\%); medium hard, frlable; slope former (locally more resistant; cliff former) tabular even; internally massive. Lower contact sharp. Contains some clay balls and minor mica. Sample 349-1.

Sandstone (8-9\%), silty, feldspathic; light grayish orange; very fine to very coarse grained, very poorly sorted, with subangular grains; soft, loose; slope former; lentic bed; internally massive. Lower contact sharp. Occurs as lenses of undetermined width, 1 to 6 feet thick. Trace magnetite and blotite; minor green hornblende. Sample 349-3 ........ Sandstone $(1-2 \%)$, conglomeratic, subfeldspathic to feidspathic; yellowish gray (weathers to light gray); very coarse grained, poorly sorted, with angular pebbles; very hard, brittle; ledge former; calcareous cemented; lentic channe1; internally thin bedded with planar cross-bedding. Lower contact sharp, irregular. Occurs as small lenses 15 to $20 \mathrm{feet}$ wide and

2 to 7 feet thick. Trace of magnetite. Sample 349-2 …150-200

Total estimated thickness ........................ 


\section{LOCALITY 350, RED HILL RED BEDS}

$\mathrm{NW}_{4} \frac{1}{4} \mathrm{SE}_{4} \frac{1}{4} \mathrm{SE}_{4}^{\frac{1}{4}}$ sec. 22, T. 2 N., R. $3 \mathrm{~W}$; Jefferson County; behind residence on southeast side of hill. Mapped by Richard (1966, P1. 1) as Bozeman group; early 0ligocene age (Alexander, 1955, p. 76). Water sample 350-3 taken from spring that rises about 150 feet east of the outcrop.

Unit

Sandstone (60\%), feldspathic to arkosic; light orange pink Estimated thick. (ft)

weathers to ina coarse to very coars grafned, moderate to poorly sorted, with angular grains of quartz and feldspar; hard, brittle; ledge former; calcareous quartz and feldspar; hard, brittle; ledge former; calcare thin beds. Lower contact sharp. Contains 10-15\% sand-sized grains of devitrified pumice. Thick beds. Sample 350-2 ...

Siltstone (40\%), micaceous; pale reddish brown; hard, brittle; slope former; porous; tabular uneven; internally massive.

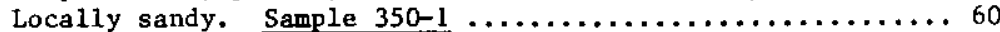

\section{LOCALITY 351. UPPER WILLOW SPRINGS ROAD SPRING}

CenterSWlisw/4 sec. 23, T. 4 N., R. 2 W.; Jefferson County; water sample 351-1 from spring about 100 feet south of road. Water rises from sediments mapped as 01igocene and Miocene tuff and gravel by Klepper and others (1957, p. 42, P1. 3).

\section{LOCALITY 352. LOWER WILLOW SPRINGS ROAD SPRING}

NWh $\mathrm{SW}^{1} \mathrm{~N} \mathrm{NE}^{\frac{1}{4}}$ sec. 21, T. 4 N., R. 2 W.; Jefferson County; water sample 352-1 taken from pond below spring on the south side of road. Water rises from sediments mapped as 0ligocene and Miocene tuff and gravel by Klepper and others $(1957$, p. 42, P1. 3).

\section{LOCALITY 353. NORTHEAST OF RED HILL}

$\mathrm{NE}^{\frac{1}{2}} \mathrm{NW}^{1} \frac{1}{4} \mathrm{NE}^{\frac{1}{4}}$ sec. 23, T. 2 N., R. 3 W.; Jefferson County; southeast side of knob. Mapped as the Bozeman group by Richard (1966, P1. 1).

$\begin{aligned} \text { Unit } & \begin{array}{c}\text { Measured } \\ \text { thick. (ft) }\end{array}\end{aligned}$

$\frac{\text { Und }}{3 .}$ Siltstone; light brown; medium hard, brittle; (weathers to soft, loose); slope former; tabular even; internally massive. Lower contact gradational $\ldots \ldots \ldots \ldots \ldots \ldots \ldots \ldots \ldots \ldots . . .6 \ldots$

2. Sandstone, feldspathic; moderate yellowish brown; medium to very coarse grained, very poorly sorted, with subangular to subrounded grafns; soft, loose; slope former; lentlc channel; internally massive. Lower contact sharp. Sample $353-2 \ldots 3.9$

1. Siltstone, sandy, tuffaceous; pinkish gray; with angular, coarse to very coarse sand grains; medium hard, brittle (weathers to medium hard to soft, frlable to loose); slope to cliff former; more resistant beds carbonate cemented; tabular even; internal parallel even thick beds. Predominately glass

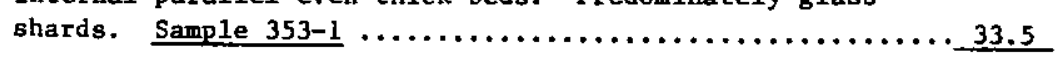

LOCALITY 353. (continued)

Unit

Measured

tal measured thickness

thick. (ft)

\section{LOCALITY 354. LOWER GARDEN GULCH}

$\mathrm{SE}_{\frac{1}{2}} \mathrm{SW}_{\frac{1}{2}} \mathrm{NE}_{\frac{1}{4}} \mathrm{sec}$. 20 , T. 4 N., R. 3 E.; Gallatin County; in reentrant on north side of gulch. Sixmlle Creek Formation of Robinson (1967).

$\frac{\text { Unit }}{3 \text {. }}$

Conglomerate, sandy; yellowish gray; with angular pebbles

stimated

thick. (ft)

Belt Series rocks and angular cobbles of limestone in a matrix

of calcareous-cemented, angular, very coarse-grained lithic sandstone; hard; ledge former. Lower contact erosional

(greater than one foot relief). Sample 354-1 ......... 25

2. Sandstone; very pale orange; medfum grained, well sorted, with subrounded grains of quartz $(60 \%)$ and rock fragments (40\%), in a carbonate cement matrix; slope former; poorly exposed. Lower contact sharp. Sample $354-2 \ldots \ldots \ldots \ldots \ldots \ldots \ldots \ldots 10$

1. Conglomerate; with subangular pebbles and cobbles of quartzite, shale, limestone, sandstone, and porphyritic volcanic rocks; hard; ledge former; carbonate cemented.................. 15

Total estimated thickness 50

\section{LOCALITY 355. CRANE SCHOOL FAULT BLOCK}

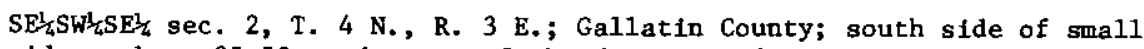
ridge, about 25-50 yards west of the dead-end of private road that connects with Roy Gulch. Lower member of Oligocene Climbing Arrow Formation of Robinson (1967). The Climbing Arrow Formation in this locality underlies an area of approximately 1 square mile. The size of the outcrop area, the sinuous depositional contacts with the older rocks (excepting the fault contacts), and the inliers of older rocks all suggest that the climbing Arrow Formation is relatively thin in the area. Dips $30^{\circ}$ or more to both east and west. Carbonaceous beds such as described below are relatively few in the area.

$\frac{\text { Unit }}{1 .}$

Estimated

laystone, silty, carbonaceous; 11ght brown; soft, friable; slope former; locally iron-stained; tabular even; internal parallel even laminae. Subordinate carbonaceous material.

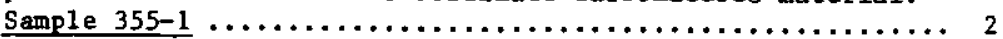

\section{LOCALITY 356. CRANE SCHOOL FAULT BLOCK SPRING}

Center sec. 11, T. 4 N., R. 3 E.; Gallatin County; water sample 356-1 from spring in sediments of the lower member of the Climbing Arrow Formation (Robinson, 1967); about 100 yards west of private road that connects with 


\section{LOCALITY 357. LAKE HELENA-HAUSER SPRING}

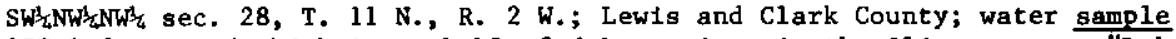
357-1 from pond which is probably fed by springs in the Oligocene age "Lake Beds" mapped by Lorenz and Swenson (1951, Pp. 16-18, P1. 1).

\section{LOCALITY 358. LAKE HELENA-HAUSER B}

SW $\frac{1}{2} \mathrm{SW}_{2}^{1} \mathrm{NW} \frac{\mathrm{L}}{4}$ sec. 28, T. $11 \mathrm{~N}$., R. 2 W.; Lewis and Clark County; 35 feet south of center of road that runs along irrigation ditch, and 160 feet east of line between sections 28 and 29 . Hand-level used to estimate thickness. Mapped as Oligocene "Lake Beds" by Lorenz and Swenson (1951, pp. 16-18, P1. 1). Strike north $40^{\circ}$ east; dip $12^{\circ}$ east.

$\frac{\text { Unit }}{6 .}$ Sandstone, pebbly; medium to coarse grained; slope former.

Estimated One foot thick, dark red iron-stained layer in middle .....20

5. Claystone, bentonitic; slope former; iron-stained to dark brownish red in center ........................... 10

4. Sandstone, locally pebbly; medium to coarse gralned, w1th angular grains; medium hard; ledge former; internally crossbedded. Contains laminae of bentonitic clay ( $10 \%$ of unit).. 3.5

3. Claystone and siltstone; medium gray to grayish brown (weathers to medium brownish gray); lentic bed. Lower contact

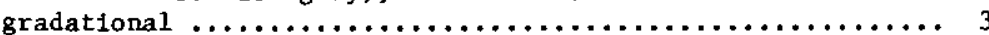

2. Sandstone, pebbly, feldspathic, tuffaceous; yellowish gray (weathers to light gray); medium grained, very poorly sorted, with subangular to angular grains; medium hard to soft; with subangular to angular grains; medium hard to soft; near base, lentic bed; internally very thin bedded, with trough cross-bedding. Lower contact sharp. Minor biotite; anomalously radioactive. Sample 358-1 of bleached center

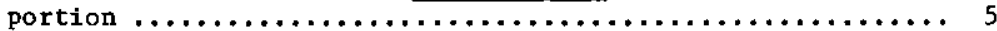

1. Claystone, sandy; pale olive (weathers to light greenish gray); soft, frangible; slope former; tabular uneven; internally

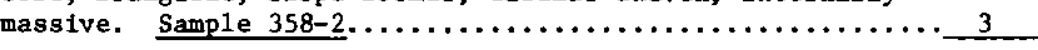

Total estimated thickness 44.5

\section{LOCALITY 359. LAKE HELENA-HAUSER C}

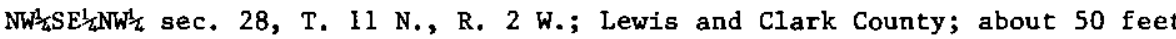
south of irrigation ditch, just east of drainageway. Mapped as Oligocene "Lake Beds" by Lorenz and Swenson (1951, pp. 16-18, Pl. 1). Strike about due east; dip 8 to $10^{\circ}$ south. Possible host rocks, ranging in thickness from 0.6 to 44.3 feet, make up $56 \%$ of the section.

Unit

Measured thick. (ft)
LOCALITY 359. (continued)

Unit

Measured

16. Claystone, sandy, bentonitic; dark brownish gra Contains a 3 foot thick lens of sandstone (similar to unit

15) about 10 feet below the upper contact $\ldots \ldots \ldots \ldots \ldots \ldots 42.8$

15. Sandstone; light orangish gray (weathers to very light gray); medium to coarse grained, moderately sorted, with angular grains; soft, loose; slope former .................... 1.5

14. Claystone, bentonitic; dark greenish gray (weathers to light gray); slope former $\ldots \ldots \ldots \ldots \ldots \ldots \ldots \ldots \ldots \ldots \ldots \ldots \ldots, 1.5$

13. Sandstone (upper 1/3), conglomeratic. Similar to lower $1 / 3$,

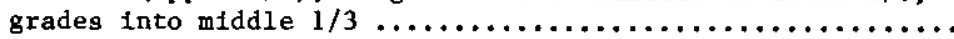
Conglomerate (m1ddle $1 / 3$ ), sandy; dark pinkish brown (weathers to light pinkish gray); with pebbles of volcanic rocks $(50 \%)$, quartz, and sedimentary rocks, in a matrix of poorly sorted, silty sand. Grades into lower $1 / 3 \ldots \ldots \ldots \ldots \ldots \ldots \ldots$. Sandstone (lower $1 / 3$ ), conglomeratic; 1 ight orangish brown (weathers to light gray); very coarse grained, moderately

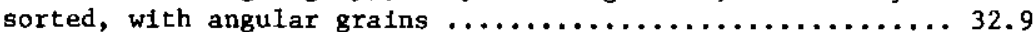

12. Claystone, sandy; medium orangish brown (weathers to medium graytsh brown); locally iron-stained. Contains some sandsized gratns of pumice $\ldots \ldots \ldots \ldots \ldots \ldots \ldots \ldots \ldots \ldots \ldots \ldots, 8$.

11. Sandstone (upper 1/3), pebbly; medium yellowish gray (weathers to light gray); medium to coarse grained, poorly sorted, with angular grains. Grades into middle $1 / 3 \ldots \ldots \ldots \ldots \ldots$ Claystone (middle 1/3), sandy; dark grayish green (weathers to medium gray). Grades into lower $1 / 3 \ldots \ldots \ldots \ldots \ldots \ldots \ldots$ Claystone (lower $1 / 3$ ), silty, bentonitic; medium yellowish

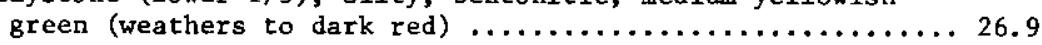

10. Sandstone, pebbly, arkosic; yellowish gray (weathers to light gray); medium to very coarse grained, poorly sorted, with angular grains, with subangular pebbles of volcanic rocks (95\%); soft, loose; slope former; porous; locally iron-stalned; tabular even. Lower contact sharp. Trace of petrified wood. Anomalously radioactive. 3 foot clay lens $11 \mathrm{feet}$ above base. Sample 359-4 taken below clay lens .............. 47.2

9. Claystone, bentonitic; dark yellowish brown (weathers to medium brown); soft, plastic (weathers to soft, loose); slope former; Iron-stained near top; tabular even. Lowe contact sharp. Very thin pinkish-brown carbonaceous layer at the top. Anomalously radioactive. Sample 359-3 ...... 3.5

8. Sandstone, pebbly, arkosic; yellowish gray and streaked'with iron-staining (weathers to light yellowish gray); coarse grafned, poorly sorted, with angular grains and pebbles; medium hard, friable; cliff former; porous; Iron-stained along upper contact; lentic bed; internally thin to medium bedded with planar cross-bedding. Lower contact sharp. Contains 
7. Claystone, silty, bentonitic; grayish olive; soft to medium hard, plastic (weathers to soft, loose); slope former; lentic bed; internally massive. Lower contact sharp. Sample 359-1.10.2

6. Sandstone, conglomeratic; medium orangish brown (weathers to Ifght yellowish gray); medium to coarse grained, poorly sorted, with angular grains; with pebbles of red, green, and gray volcanic rocks; iron-stalned. Minor reworked petrified

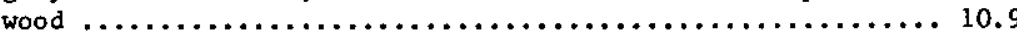

5. Claystone; dark greenish gray

4. Claystone (70\%), sandy; dark graylsh green (weathers to dark

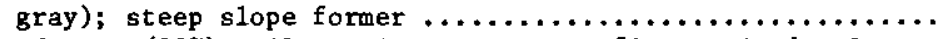
Sandstone (30\%), silty, micaceous; very fine grafned. Occurs as three thin lenses in the claystone $\ldots \ldots \ldots \ldots \ldots \ldots \ldots, 4.8$

3. Sandstone, conglomeratic; medium to very coarse grained, moderately sorted, with angular grains, with pebbles of gray, green, and red volcanic rocks; minor clay lenses .......... 12.3

2. Claystone, medium greenish gray; steep slope former $\ldots \ldots \ldots .7 .4$

1. Sandstone, quartz; 11ght yellow (weathers to 1ight gray); medium grained, with angular grains; soft, friable; slope former. Minor heavy minerals........................ 1.5

Total measured thickness 234.1

\section{LOCALITY 360. LAKE HELENA-HAUSER D}

NWh $\mathrm{NE}_{\frac{1}{4} \mathrm{SE}} \frac{1}{4}$ sec. 28, T. 11 N., R. 2 W.; Lewis and Clark County; east of Irrigation ditch. Mapped by Lorenz and Swenson (1951, pp. 16-18, P1. 1), as Oligocene age "Lake Beds". Strike north $66^{\circ}$ west; dip 12 to $15^{\circ}$ south (Becraft, 1958, Fig. 17, has the dips reversed for this outcrop).

$\frac{\text { Unit }}{13 .}$

Measured

laystone, bentonitic; dark green at base; yellowish green and silty in middle; yellowish tan and pebbly near top ........ 14.3

12. Siltstone, sandy, pebbly; grayish yellow (weathers to medium gray); with very poorly sorted, medium to very coarse grained sand; medium hard, brittle; slope former; locally iron-stained, tabular even; Internally massive. Lower contact gradational. Upper $1 / 2$ bentonitic. Unit capped by a tabular even 1.5 foot thick bed of very hard, brittle, white to medium gray chalcedony or silicified siltstone.

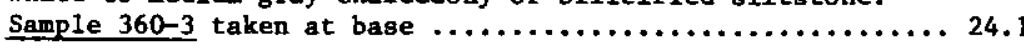

11. Sandstone, sllty, tuffaceous; yellowish gray; coarse grained, poorly sorted, with angular grains; medium hard, friable; slope former; porous; tabular even. Lower contact sharp.

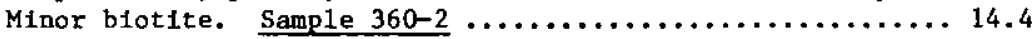

10. Siltstone, sandy, pebbly; medium purplish gray (weathers to medium greenish gray); with angular pebbles of greenish-gray volcanic rocks. slightly bentonitic. Contains minor carbonaceous plant stems and some medium to coarse sand-gized

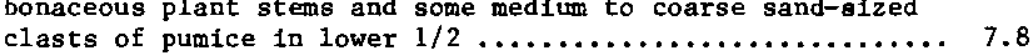

9. Shale, carbonaceous, clayey; ledge former; tabular even; internal very thin to laminated parallel even beds. Lower contact sharp. Subordinate carbonaceous material ............ 10

8. Claystone, tuffaceous; medium brownish gray; iron-stained in middle. Contains smokey quartz and sand-sized clasts of pumice. Upper $1 / 2$ contains subordinate non-tuffaceous claystone interbedded with the tuffaceous claystone and is locally pebbly. Lower $1 / 2$ contains a trace of silicified

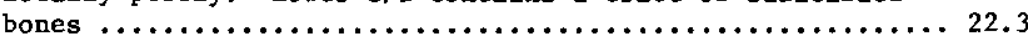

7. Claystone, sandy; medium yellowlsh gray (weathers to light gray); with coarse sand-sized grains of pumfe. Slightly

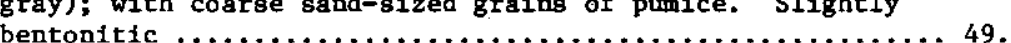

6. Claystone, silty to sandy; weathers to light.yellowish gray with grains of pumice. Upper $25 \%$ banded with partially

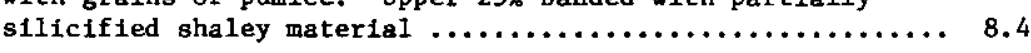

5. Shale (becomes very carbonaceous at top); medium orangish brown at base to grayish pink at top (weathers to light whitish yellow); hard, brittle; ledge former; tabular even; internally laminated. Lower contact sharp. Anomalously radioactive. Sample $360-1$ of carbonaceous upper portion .............. 1.2

4. Claystone, sandy; dark brownish orange (dark purplish brown where locally carbonaceous); slope former ............. 3.8

3. Shale; light purplish white; hard, brittle. Probably car-

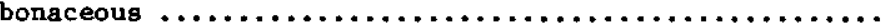

2. Claystone, sandy; medium brown1sh yellow (weathers to Iight gray); slightly bentonitic. Contains smokey quartz ....... 5.8

1. Claystone, bentonitic; medium yellowish-greenish gray (weathers

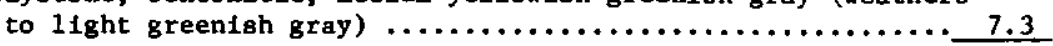
Total measured thickness $\ldots \ldots \ldots \ldots \ldots \ldots \ldots \ldots \ldots \ldots \ldots \ldots . \ldots \ldots 9 . \ldots \ldots$ 


\section{LOCALITY 361. BEACON HILL CROSS-BEDS}

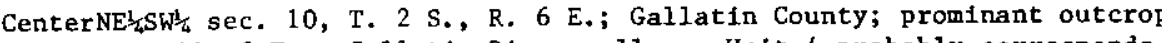
on north wall of East Gallatin River valley. Unit 4 probably corresponds to unit 4 of the stratigraphic section of Glancy (1964, pp. 58-63) In the to early Plfocene age sediments of the Bozeman Group (pp. 9 and 31 ). Strike north $70^{\circ}$ west; age sediments of the Bozeman Group (Pp. 9 and 31). Strike north $70^{\circ}$ wes dip $15^{\circ}$ north.

Unit

Sandstone; light brown to medium gray; medium to coarse gralned, thick. ( $\mathrm{ft}$ ) well sorted, composed of angular glass shards; medium hard, friable; cliff former; porous; internally laminated to very thin bedded, whth large sorale cross-bedso 1 .

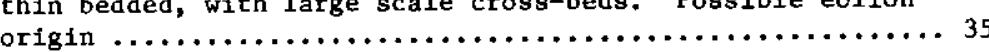

3. Siltstone $(86 \%)$, tuffaceous, locally conglomeratic; compact. Forms upper $1 / 3$ of unit and $80 \%$ of lower $2 / 3^{\text {'s }}$ of unft. In lower $2 / 3^{\prime}$ s of unit, the siltstone occurs in 2 to 5 foot beds, interbedded with sandstone and conglomerate ..................... Sandstone $(7 \%)$, tuffaceous; similar to unit 1 . Interbedded with conglomerate and siltstone. Occurs in lower $2 / 3$ of unit. Conglomerate $(7 \%)$; similar to unit 2 . Occurs in lower $2 / 3$

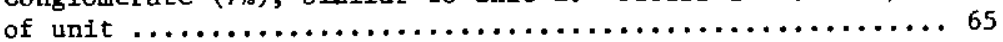

2. Conglomerate; with a matrix of medium to fine grained, poorly sorted, quartz sand.............................. 9

1. Sandstone, tuffaceous; 11ght brown; fine grained; friable .... 4

Total estimated thickness

\section{LOCALITY 362. LITTLE HORSESHOE BASIN}

$\mathrm{NE}_{4}^{1} \mathrm{SW}_{2}^{1} \mathrm{NE}_{4}^{\frac{1}{4}}$ sec. 27 , T. 3 N., R. 4 E.; Gallatin County; on west-facing slope at east end of basin. Hand level used to estimate thickness. The rocks are of O1fgocene age (Klemme, 1949, P. 69; Verrall, 1955, p. 172-173). Strike north $11^{\circ}$ east; dip $10^{\circ}$ east.

$\frac{\text { Unit }}{7 \text {. }}$

Estimated

thick. (ft) 11 tstone; medium orangish brown; medium hard; cliff former;
calcareous and sandy at the top $\ldots \ldots \ldots \ldots \ldots \ldots \ldots \ldots \ldots \ldots, 8$

6. Siltstone; brown to grayish brown; medium hard, friable; very thinly bedded and calcareous at top $\ldots \ldots \ldots \ldots \ldots \ldots \ldots \ldots .6 .5$

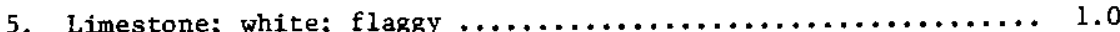

4. Siltstone; porous. Contains distinctive $1 / 4$ to $1 / 2$ inch

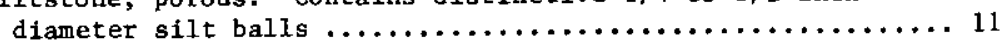

3. Siltstone; ledge former. Root casts. Lower 3 feet covered... 5

2. Sandstone; medium orangish brown; very fine grained; slightly calcareous, 6 inch bed of 1 imestone at top ............. 15
LOCALITY 362. (continued)

$\frac{\text { Unit }}{1 .}$

Limestone; 1ight yellowish gray; laminated; fissile thick. (ft)

Total estimated thickness

87.5

\section{LOCALITY 364. MILLIGAN CANYON ROAD EXIT No. 4}

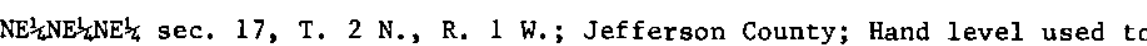
estimate thickness. Climbing Arrow Formation of Robinson (1963, pp. 69-77, P1. 1). Strike north $2^{\circ}$ west; dip $5^{\circ}$ east.

$\frac{\text { Unit }}{10 .}$ Sandstone, pebbly; coarse grained. Contains petrified wood... $\frac{\text { thick. }(\mathrm{ft})}{8}$

9. Claystone, bentonitic; westhers to medium yellowish gray. 0.5 foot thick lenses of sandstone make up less than $5 \%$ of the

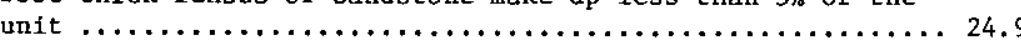

8. Sandstone, pebbly; alternating fine and coarse grained beds; porous; iron-stained; lentic channe1 ................ 5

7. Claystone; medium yellowish green; iron-stained ............

6. Sandstone; light grayish yellow; medium grained, with angular grains. Top 2 inches cemented with fron oxides ........... 10.8

5. Sandstone, conglomeratic, subfeldspathic; weathers to medium brownish red; medium to coarse grained, poorly sorted, with angular grains and rounded pebbles; medium hard; ledge

former. Contains a minor biotite and some smokey quartz ... 1.0

4. Sandstone, conglomeratic; medium to dark orangish brown; coarse grained, poorly sorted, with subangular to subrounded pebbles and cobbles of igneous rocks, metamorphic rocks, and quartz-

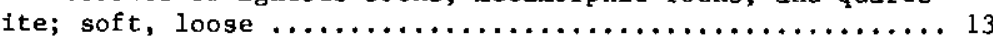

3. Siltstone, clayey, tuffaceous; white. Composed of glass

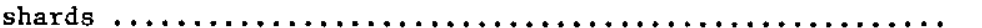

2. Sandstone, light orangish gray (weathers to medium gray); medium grained, poorly sorted. Contalns a 2 foot thick layer of bentonitic clay 8 feet above base. Upper $1 / 2$ of unit is

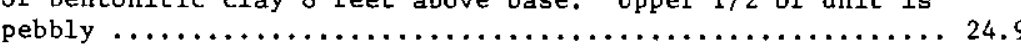

1. Claystone, silty and sandy, bentonitic; dark greenish brown (weathers to medium gray); poorly sorted, with grains of pumice. Several medium thick lenses composed of silt to very poorly sorted, coarse-grained sand make up less than $10 \%$ of

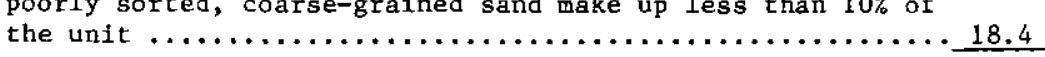

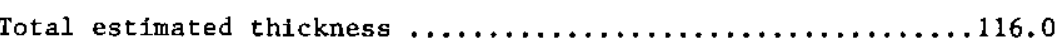


NE $\frac{1}{2} \mathrm{NE}_{2} \mathrm{NE}_{2}$ sec. 19, T. 9 N., R. 1 E.; Broadwater County; south side of gulch. Hand level used to estimate thickness. Basal portion of Tertiary unit 2 of 011gocene age (Mertie and others, 1951, p. 33-35, P1, 1 and 2) and Becraft (1958, pp. 151-159, Pl. 3). Strike north $20^{\circ}$ west; dip $14^{\circ}$ east. Unit Estimated

Sandstone, tuffaceous; white; fine to medium grained; ledge thick. ( $\mathrm{Et}$ )

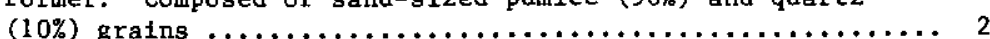

6. Claystone; dark greenish brown (weathers to medium greenish brown); slope former. 2 inches of chalcedony at base; silfciflcation decreases upward $\ldots \ldots \ldots \ldots \ldots \ldots \ldots \ldots \ldots, 8.3$

5. Siltstone; similar to unit $3 \ldots \ldots \ldots \ldots \ldots \ldots \ldots \ldots \ldots \ldots \ldots$

4. Siltstone, tuffaceous; 11ght greenish gray (weathers to white);

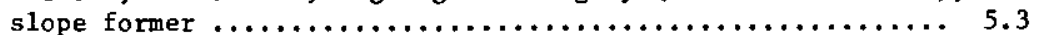

3. Siltstone, sandy, tuffaceous; white, medium hard; ledge former. 1.4

2. Sandstone (upper $1 / 2$ ), tuffaceous; medium yellowish gray; medium size grains of pumice (90\%), quartz, and rock frag-

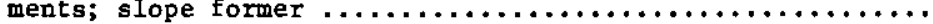
Shale (lower 1/2), dark gray (weathers to 1ight yellowish

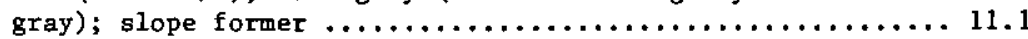

1. Conglomerate, tuffaceous; white; with well rounded pebbles of pumice $(95 \%)$ and subangular to subrounded pebbles to coarsesand-sized grains of dark volcanic rocks $(5 \%)$, in a tuffaceous matrix; medium hard, ledge former $\ldots \ldots \ldots \ldots \ldots \ldots, 4.8$

Total estimated thickness 36.8

\section{LOCALITY 367. RABBIT CREEK ROADCUT}

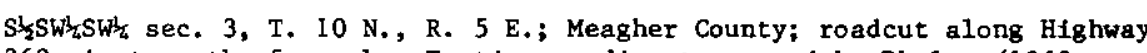
360, just north of creek. Tertiary sediments mapped by Phelps (1969, pp. 27 and 28, Pl. 1); close to contact between the Miocene Deep River and Fort Logan Formations of Koerner (1939, P1ate XXVI). Th1s un1t is character1stic of the Tertiary in the Smith River Valley.

$\frac{\text { Unit }}{1 .}$

Siltstone, medium brown; medium hard, compact; internally massive; porous; slightly calcareous; composed of glass

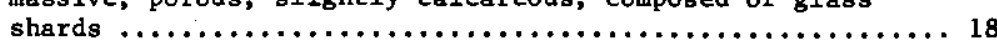

Estimated thick. $(f t)$

\section{LOCALITY 368. BEAVER CREEK ROADCUT}

NW $\frac{1}{6} \mathrm{SWBNE}_{4}^{\frac{1}{4}}$ gec. 3, T. 11 N., R. 4 E.; Meagher County; along road just north of creek. Tertiary sedfments mapped by Hruska (1967, pp. 43-51, P1. 1) and 18 considered "most likely to belong to the Fort Logan Formations" (p. 49) of early Miocene age (Koerner, 1939, pp. 30-36).

\section{$\frac{\text { Undt }}{1 .}$ tstone to fine gralned sandstone, tuffaceous; medium brown medtum hard, compact; massive; predominately glass shards. Contains medium thick gray ash or tuff bed ..............35-40}

\section{LOCALITY 369. UNNAMED GULLY}

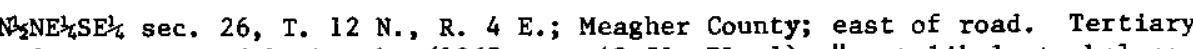
sediments mapped by Hruska (1967, pp. 43-51, P1. 1); "most 11kely to belong to the Fort Logan Formation" (p. 49) of early Miocene age (Koerner, 1939, pp. 30-36).

Unit

Estimated

thtone to fine grained sandstone; medium brown; medium hard, compact; generally massive, but thin bedding locally visible. Contains thick lens of soft, loose, medium grained quartz sand that fines upward into the siltstone $\ldots \ldots \ldots \ldots 20$

\section{LOCALITY 372. HIGHWAY 12 INTERSECTION}

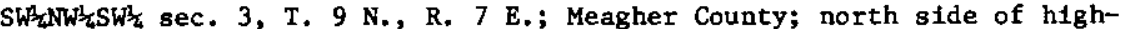
way, just east of highway maintenance building. Mapped as Tertiary sediments by Dahl $(1971$, p. 23, P1. 1) and as Miocene Deep River Formation by Tanner (1949, pp. 87-90, P1. 1).

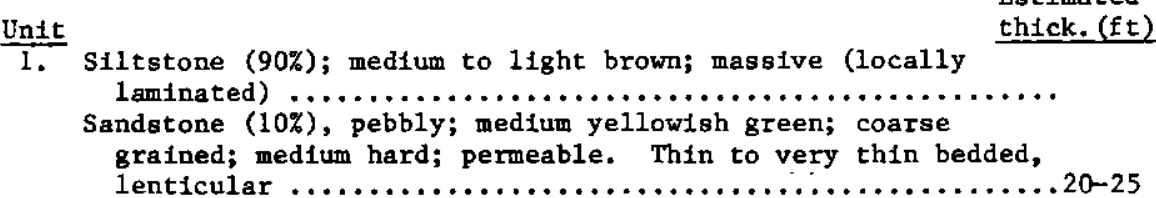

\section{LOCALITY 373. CAMAS CREEK SECTION}

$\mathrm{NW}_{4} \mathrm{SW}_{4} \mathrm{SE}_{\frac{1}{4}} \mathrm{sec} .26$, T. $11 \mathrm{~N} .$, R. 4 E.; Meagher County; approximately 75 yards north of house, on west bank of creek. Hand level used to estimate thickness. Mapped as Miocene tuffs by Birkholz (1967, pp. 26-28, P1. 1). Strike north $66^{\circ}$ east; dip $6^{\circ}$ east.

$\frac{\text { Unit }}{3 .}$ Siltstone, sandy, and very fine grained sandstone; light

Estimated brown; permeable. Lower contact gradational thick. (ft)

2. Siltstone; medium gray; permeable; composed of glass shards.

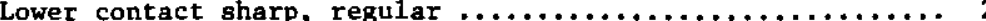

1. Siltstone; dark brown (weathers to 11 ght brown), permeable.

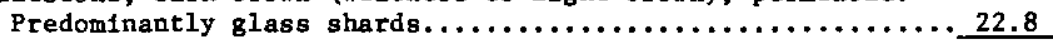
Total estimated thicknesa $\ldots \ldots \ldots \ldots \ldots \ldots \ldots \ldots \ldots \ldots \ldots, \ldots \ldots . . \ldots$ 


\section{LOCALITY 374. ROCK SPRINGS CREEK SECTION}

$\mathrm{NW}_{\frac{1}{4}} \mathrm{NW}_{\frac{1}{4}} \mathrm{NWW}_{4}$ sec. 9, T. $10 \mathrm{~N}$., R. 5 E.; Meagher County; on southeast side of point. Hand level used to estimate thickness. Unit 1 described below probably corresponds with the lower Miocene Fort Logan Formation of Koerner (1939, pp. 29-36, Pl. XXVI); units 2 and 3 probably correspond to the upper Miocene Deep River Formation of Koerner (p. 29, pp. 46-54, P1. XXVI).

$\frac{\text { Unit }}{3}$

Siltstone and very fine grained sandstone; brown; medium har

Estimated

hick. ( $\mathrm{ft}$ )

to soft, frlable; steep slope former; generally massive

(bedding becomes more distinct near base). Lower contact

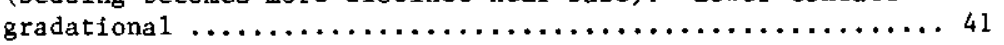

2. Sandstone, pebbly; coarse to very coarse grained, with angular grains, with angular flat pebbles of shale; parallel even thin beds interbedded with fine grained sandstone; cliff former. Lower contact erosional, unconformable on unft $1 . . .8$

1. Siltstone; light medium brown to light brownish gray; soft to medium hard, friable; steep slope former; permeable, locally calcareous; massive; very thick bedding; predominantly

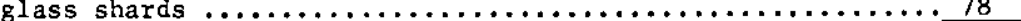

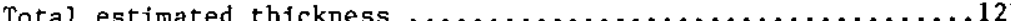

\section{LOCALITY 375. WHITETAIL DEER CREEK GULLY}

$\mathrm{NW}^{\frac{1}{4}} \mathrm{SE}^{\frac{1}{4}} \mathrm{SW} W^{\frac{1}{4}} \mathrm{sec} .8$, T. 11 N., R. 5 E.; Meagher County; east side of gully that parallels road. Mapped as Tertiary sediments by Phelps (1969, Pp. 27-28, P1, 1) and as lower Miocene Fort Logan Formation by Koerner (1939, pp. 46-54, P1. XXVI).

Unit

Siltstone; tuffaceous; very hard; ledge former; calcareous

Estimated cemented. Manganese oxide dendrites ................ 7-8

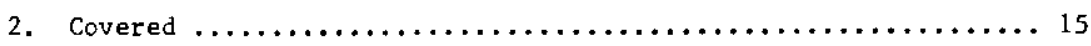

1. Siltstone; soft, frlable, slope former; Internally medium to thick bedded. Medium thick ash beds make up 25-30\% of unit. 35

Total estimated thickness $. .57-58$

\section{LOCALITY 376. WHITETAIL DEER CREEK KNOB}

$\mathrm{N}^{\frac{1}{2}} \mathrm{NE}^{\frac{1}{4}} \mathrm{SW}^{\frac{1}{4}} \mathrm{sec}$. 17, T. $11 \mathrm{~N}$., R. 5 E.; Meagher County; knob on east side of gully west of road. Mapped as Tertiary sediments by Phelps (1969, pp. 27-28, P1. 1) and as the lower Miocene Fort Logan Formation by Koerner (1939, pp. $46-54, \mathrm{Pl}$. XXVI).

\section{LOCALITY 376. (continued)}

$\frac{\text { Unit }}{1 .}$ Siltstone; 1ight to medium brown; medium hard; $30 \%$ of beds thick. (ft) calcareous; internal parallel even, medium beds. Predominantly glass shards. Relatively resistant, gray, fine grained tuff beds make up $20 \%$ of lower half of unit ......60-70

\section{LOCALITY 377. HARRISON CEMETARY}

$\mathrm{SW}^{\frac{1}{4} \mathrm{NW}} \frac{1}{4} \mathrm{SE} \frac{1}{4}$ sec. 24, T. 1 S., R. 2 W.; Jefferson County; west-facing slope. Mapped as Tertiary "Lake Beds" by Berry (1943, p. 22, P1. 1).

Unit

Estimated

1. Siltstone, sandy; medium hard, brittle thick. (ft)

\section{LOCALITY 378. NORTHERN PACIFIC RAILROAD CUT}

$S W^{\frac{1}{4}} \mathrm{NE}^{\frac{1}{4}} \mathrm{NE}_{\frac{1}{4}} \mathrm{sec}$. 23, T. 1 S., R. 2 W.; Jefferson County; railroad cut north of county highway $359,100-200$ yards west of intersection of highway and railroad. Mapped as Tertfary "Lake Beds" by Berry (1943, p. 22, P1. 1).

Unit

Estimated

2. Sandstone, pebbly; soft, loose (locally hard, brittle; silica. (ft) cemented); slope former. Anomalously radioactive. Contains trace of petrified wood with secondary uranium mineralization

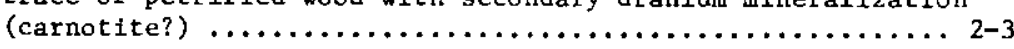

1. Siltstone; light greenish gray; medium hard; porous; internally massive. Locally pebbly, bentonitic ............. 10

Total estimated thickness $.12-13$

\section{LOCALITY 381. POLE GULCH CONGLOMERATE}

SW $\frac{1}{4} \mathrm{NW}^{\frac{1}{2}} \mathrm{NW} \frac{1}{4} \mathrm{sec} .5$, T. 3 N., R. 3 E.; Gallatin County; on north wall of gulch. Mapped by Robinson (1967) as the rounded sand and gravel member of the Miocene and Pliocene age Sixmile Creek Formation.

$\begin{array}{ll}\text { Unit } & \text { thick. ( } \mathrm{ft} \text { ) }\end{array}$ moderately sorted, with angular grains; hard; ledge former cross-bedded. Minor heavy minerals.

Conglomerate $(40 \%)$; with well rounded pebbles and cobbles of quartzite and quartz (75\%), and subordinate amounts of granite, metamorphic rocks and volcanic rocks in a matrix of calcareous-cemented sandstone; hard; ledge former.

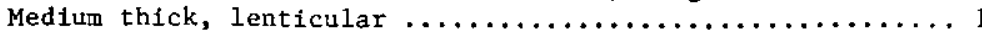



APPENDIX B

SELECTED STRATIGRAPHIC AND LITHOLOGIC DATA FOR STRATIGRAPHIC SECTIONS DESCRIBED IN THE LITERATURE 
APPENDIX B

STRATIGRAPHIC SECTIONS DESCRIBED IN THE LITERATURE ${ }^{a}$

\begin{tabular}{|c|c|c|c|c|c|c|c|c|c|c|c|c|c|c|c|c|c|c|}
\hline \multirow[b]{2}{*}{$\begin{array}{l}\text { Section } \\
\text { number }\end{array}$} & \multirow[b]{2}{*}{ ence } & \multirow[b]{2}{*}{$\begin{array}{l}\text { Section name } \\
\text { or number }\end{array}$} & \multirow[b]{2}{*}{$\mathrm{Age}^{\mathrm{b}}$} & \multirow{2}{*}{ 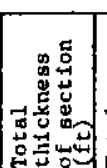 } & \multirow{2}{*}{ 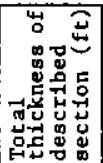 } & \multicolumn{6}{|c|}{ Potential host rocks ${ }^{c}$} & \multicolumn{2}{|c|}{$\begin{array}{l}\text { Organic } \\
\text { material }\end{array}$} & \multirow{2}{*}{ 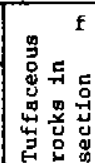 } & \multirow[b]{2}{*}{$\begin{array}{c}\text { Other } \\
\text { characteristics }\end{array}$} & \multirow{2}{*}{\multicolumn{2}{|c|}{ 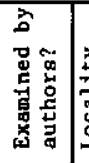 }} & \multirow{2}{*}{ 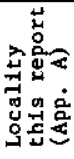 } \\
\hline & & & & & & $\begin{array}{c}\text { \% of desc. } \\
\text { sec. }\end{array}$ & 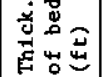 & $\begin{array}{l}\text { Fld } \\
\text { or } \\
\text { ark }\end{array}$ & Sorting $\mathrm{e}$ & 光 & 总 & 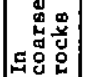 & 天 & & & & & \\
\hline
\end{tabular}

Flint Creek basin

$\begin{array}{ll}\text { Rasmussen, 1969, p. } 159 & \text { B of MV6549 } \\ \text { Rasmussen, 1969, p. 151-155 } & \text { MU6554, Part III } \\ \text { Rasmussen, 1969, p. 155-159 } & \text { MU6554, Part IV } \\ \text { Rasmussen, 1969, p. } 160-167 & \text { MU6558, Part I } \\ \text { Rasmussen, 1969, p. 167-174 } & \text { MU6504, Part II } \\ \text { Rasmussen, 1969, p. 174-180 } & \text { MU6552, Sec. D }\end{array}$

$\begin{array}{cccr}\text { M-P } & 46 & 46 & 100 \\ \text { M-P } & 102 & 102 & 21 \\ \text { M-P } & 174 & 174 & 15 \\ \text { M-P } & 1161.5 & 427.5 & 04 \\ \text { M-P } & 438 & 393 & 04 \\ \text { M-P } & 86.3 & 86.3 & 02\end{array}$

$\begin{array}{ccccll}46 & \text { ark } & \text { VW-VP } & \text { no } & \text { yes } & - \\ 2-10 & \text { ark } & \text { M } & \text { no } & \text { no } & - \\ 1-4 & \text { ark } & \text { W-P } & - & - & - \\ 3-9 & \text { ark } & \text { P-W } & - & \text { yes } & - \\ 3-4 & \text { ark } & \text { P } & - & \text { yes } & - \\ 1 & - & - & - & - & -\end{array}$

\begin{tabular}{cc}
- & $T$ \\
A & S-D \\
- & D \\
- & $D$ \\
- & $D$ \\
\hline & $D$
\end{tabular}

$\begin{array}{lll} & \text { yes } & 110 \\ \text { opalized wood } & \text { yes } & 111 \\ \text { plant fragments } & \text { no } & \\ \text { wood fragments } & \text { no } & \end{array}$

B1tterroot basin

$\begin{array}{ll}7 & \text { McMurtrey and others, 1972, p. } 19-20 \\ 8 & \text { McMurtrey and others, 1972, p. } 15\end{array}$

$\begin{array}{llll}\text { M-P } & 152.1 & 152.1 & 80 \\ \text { M-P } & 227 & 142 & 61\end{array}$

$\begin{array}{ll}2-30 & \text { fld } \\ 5-30 & \text { ark }\end{array}$

$\begin{array}{cr}P & \text { no } \\ P-M & \text { no }\end{array}$

$\begin{array}{llll}\text { yes } & - & \text { T } & \text { - } \\ \text { no } & - & - & \text { S }\end{array}$

$\begin{array}{ll}\text { yes } & 125 \\ \text { yes } & 128\end{array}$

Jefferson River, Beaverhead River, and Lower Ruby River basins

p. 269-270 and Lot

10 Kuen, 1966, p. 269-270

11 Kuenzi, 1966, p. 220-242

Kuenzi, 1966, p. 220-26

Sunlute

Parrot Bench

Parrot Bench

Kuenz1, 1966, p. 277-286

Ruenz1, 1966, p. $277-286$

Kuenz1, 1966, p. 274-276

Kuenz1, 1966, p. 263-26

Kuenz1, 1966, p. 265-266

Petkewich, 1972, p. 300-303

Petkew1ch, 1972, p. 303-308

Petkewich, 1972, p. 308-310

Petkewich, 1972, p. 310-315

Petkewich, 1972, p. 315-318

Petkewich, 1972, p. 318-326

Petkewich, 1972, p. 332-334

Petkew1ch, 1972, p. 334-336

Petkewich, 1972, p. 337

Petkewich, 1972, P. 338-340

Hof fman, 1972, P. $1460-151$

Pof 1972 , P. 146-151

Hoffman, 1972. p. 154

Palisan River

Palisade Cliff

Easter L11y

Pipestone Springs

E-O

$\begin{array}{llr} & 48 \\ \text { Williams Creek sec., } & \text { M-P } & 2130\end{array}$

Williams Creek sec., E-0 $1740 \quad 1310$

segments $A, B$ and $D$

Burnt Hills Reservior E-0 745

Borof sky Ranch sec.,

Plant Locality

Descheemaeker Ranch

Mule Shoe Ditch

Swan Ranch

Confusion

Bliss

Georg1a Gulches

Diamond 0 Ranch A-O

Van Deren Ranch sec.

Biltmore Duck Pond

$\begin{array}{rr}61 & 61 \\ 145 & 145 \\ 2419 & 919 \\ 776 & 776 \\ 965 & 873 \\ 48 & 48 \\ 320 & 292 \\ 275 & 275 \\ 176 & 176 \\ 178 & 173 \\ 48 & 48 \\ 2130 & 780 \\ 1740 & 1310 \\ & \\ 745 & 467 \\ 845 & 687 \\ 198 & 198 \\ 1467 & 657 \\ 740 & 417 \\ 46 & 46 \\ 355 & 140 \\ 64 & 64 \\ 140 & 140 \\ 965 & 881 \\ 87 & 87 \\ 73 & 73 \\ 120 & 120 \\ & \end{array}$

$\begin{array}{rcc}13 & 1-3 & \text { ark } \\ 0 & 0 & - \\ 64 & 1-33 & \text { fld } \\ 10 & 11 & \text { fld } \\ 28 & 1-22 & \text { fld } \\ 91 & 1-38 & \text { ark } \\ 10 & 1-5 & \text { ark } \\ 12 & 1-27 & \text { fld } \\ 01 & 1 & \text { fld } \\ 04 & 7 & \text { fld } \\ 26 & 4-8 & \text { fld } \\ 100 & 5-340 & - \\ & & \\ 01 & 8 & - \\ & & \\ 2 & 5 & - \\ 30 & 1-45 & \text { fld } \\ & & \\ 39 & 26 & - \\ 47 & 47 & - \\ 55 & 1-35 & - \\ 50 & 2-16 & \text { fld } \\ 23 & 12-20 & \text { fld } \\ 100 & 3-29 & \text { fld } \\ 85 & 1-64 & \text { fld } \\ 78 & 1-47 & \text { f1d } \\ 26 & 2-10 & - \\ 10 & 10 & - \\ 26 & 5-16 & -\end{array}$

M-P
-
$P-W$
$P-W$
$M-W$
WP
$M-P$
$M-P$
$P$
$P$
M-P
$P$
$P$
$P$
-
$M-P$
$M-P$
$M-P$
$M-P$
$M-P$
$P$
$P$
$P$
$W-P$
$M-W$
-
-

\section{xes}

$\frac{-12}{2}$

$\bar{T}$

T
A
S
A
A
N
S
A
A
A
T
A
A
A
A
A
S
S
A
A
A
A
S
A
-

yes 201

yes 202

yos 203

yes 204

yes

no

adash means information not avallable.

$b_{M-P}$, Miocene and P1iocene; E-O, Eocene and Oligocene

Medium to coarse grained or conglomeratic.
$d_{\mathrm{PF}}$ - 0-10\% feldspar; f1d - feldspathic; ark - arkosic

$e_{V}$ - very; $W=$ well; $M$ - moderate; $P$ = poor

$f_{\mathrm{P}}=$ present but amount unknown; $\mathrm{T}=$ trace $(<17) ; \mathrm{A}=$ accessory $(1-10 \%)$; 
APPENDIX B (continued)

\begin{tabular}{|c|c|c|c|c|c|c|c|c|c|c|c|c|c|c|c|c|}
\hline \multirow[b]{2}{*}{$\begin{array}{l}\text { Section } \\
\text { number }\end{array}$} & \multirow[b]{2}{*}{ ference } & \multirow[b]{2}{*}{$\begin{array}{l}\text { Section name } \\
\text { or number }\end{array}$} & \multirow[b]{2}{*}{$\mathrm{Age}^{\mathrm{b}}$} & \multirow{2}{*}{ 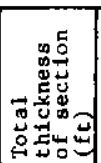 } & \multirow{2}{*}{ 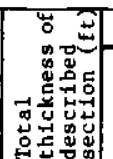 } & \multicolumn{6}{|c|}{ Potentlal host rocks ${ }^{c}$} & \multicolumn{2}{|c|}{\begin{tabular}{|l|} 
Organic \\
matertal \\
\end{tabular}} & \multirow{2}{*}{ 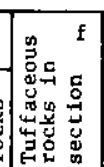 } & \multirow[b]{2}{*}{$\begin{array}{c}\text { Other } \\
\text { characteristics }\end{array}$} & \multirow{2}{*}{ 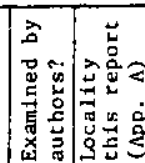 } \\
\hline & & & & & & $\begin{array}{c}\% \text { of desc. } \\
\text { sec. }\end{array}$ & 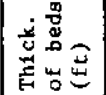 & $\begin{array}{l}\text { Fld } \\
\text { or } \\
\text { ark }\end{array}$ & Sorting & 点 & 总 & 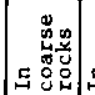 & 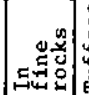 & & & \\
\hline
\end{tabular}

35 Hof fman, 1972, p. 155

Upper Ruby River and Sage Creek basins

37 Dorr and Wheeler, 1964,

38 p. $309-312$

Dorr and Wheeler, 1964,

p. 309-312

Dorr and wheeler, 1964 ,

p. 312-314

Dorr and Wheeler, 1964 ,

p. $314-317$

Dorr and wheeler, 1964,

p. $317-319$

P.

North Bench Gravel PIt

Sweetwater Creek

Sweetwater Creek

Belmont Ranch

Idaho Creek

Barton Creek

Blacktail Deer Creek

Grasshopper Creek and Horse Prairie basin

43 M'Gonigle, 1965, P. 139-140 Table

44 M'Gonigle, 1965, p. 141-146
Three Forks basin

45 Robinson, 1963 , p. 78

46 Feichtinger, 1970,

p. $65-68$

Feichtinger, 1970,

Schne1der, 1970, p. 54-56

Schneider, 1970, p. 59

Schneider, 1970, p. 60-61

Hackett and others, 1960,

p. 37

Hackett and others, 1960

p. $38-39$

Miffin, 1963, p. 17-18

Mifflin, 1963, p. 18-19

Glancy, 1964, p. 58-63

\section{Table 8
Table 9}

Area

sec. I

partial stra

sec. IV

partial stratigraphic
sec. III

partial

partial stre
sec. VI

Section of Unit 1

Section of Unit

Section No. 1

No.

Beacon H111

$\begin{array}{lll}56 & \text { Alexander, 1955, p. xxi1 } & \text { Section } 15 \\ 57 & \text { Alexander, 1955, p. xx11i } & \text { Section } 16\end{array}$

Boulder River basin

Dash mean information not avallable.

$b_{M-P,}$ Miocene and Pliocene; $E-O$, Eocene and Oligocene

cMedium to coarse grained or conglomeratic.
171

272

M-P $\quad 252 \quad 252$

E-O $130 \quad 130$

M-P $\quad 1136 \quad 482$

M-P $\quad 749 \quad 442$

M-P $\quad 369 \quad 369$

$M-P \quad 400 \quad 400$

$\begin{array}{lll}\text { M-P } & 1326 & 1326 \\ M-P & 6181 & 5480\end{array}$

E-0 $315 \quad 260 \quad 20$

E-O $\quad 387 \quad 330$

E $00 \quad 387$

$M-P \quad 289$

M-P 146

M-P 530

$\begin{array}{llll}M-P & 921.5 & 671.5 & 15\end{array}$

$\begin{array}{llll}\text { M-P } & 373 \quad 318 & 30\end{array}$

$\begin{array}{lllr}M-P & 113 & 113 & 0 \\ M-P & 200 & 162 & 07\end{array}$

$\begin{array}{lr}M-P & 200 \\ M-P & 2016\end{array}$

717

$\begin{array}{lll}\text { M-P } & 141 & 141 \\ M-P & 199 & 199\end{array}$

$d_{N F}-0-10 \%$ feldspar; fld - feldspathic; ark - arkosic

$\mathrm{e} V=$ very; $W=$ well; $M=$ moderate; $P=$ poor

$\begin{aligned} f_{P}= & \text { present but amount unknown; } T=\text { trace }(<1 \%) ; A=\text { accessory }(1 \%-10 \%) ; \\ & S=\text { subordinate }(10 \%-50 \%) ; D=\text { dominant }(>50 \%)\end{aligned}$ no

no

no

no 
APPENDIX B (continued)

\begin{tabular}{|c|c|c|c|c|c|c|c|c|c|c|c|c|c|c|c|c|}
\hline \multirow[b]{2}{*}{$\begin{array}{l}\text { Section } \\
\text { number }\end{array}$} & \multirow[b]{2}{*}{ Reference } & \multirow[b]{2}{*}{$\begin{array}{l}\text { Section name } \\
\text { or number }\end{array}$} & \multirow[b]{2}{*}{$\mathrm{Age}^{\mathrm{b}}$} & \multirow{2}{*}{ 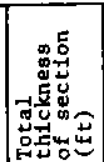 } & \multirow{2}{*}{ 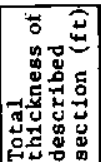 } & \multicolumn{6}{|c|}{ Potent1al host rocks ${ }^{c}$} & \multicolumn{2}{|c|}{ Organic } & \multirow{2}{*}{ 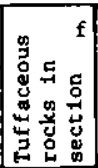 } & \multirow[b]{2}{*}{$\begin{array}{l}\text { Other } \\
\text { characteristics }\end{array}$} & \multirow{2}{*}{ 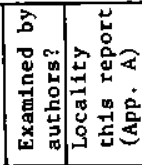 } \\
\hline & & & & & & $\begin{array}{l}\text { tof desc. } \\
\text { gec. }\end{array}$ & 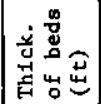 & $\begin{array}{l}\text { F1d } \\
\text { or } \\
\text { ark } d\end{array}$ & Sorting ${ }^{e}$ & 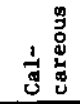 & 总 & 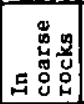 & 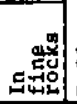 & & & \\
\hline
\end{tabular}

\begin{tabular}{|c|c|c|c|c|c|c|c|c|c|c|c|c|c|c|c|c|}
\hline $\begin{array}{l}\text { Townsend } \\
58\end{array}$ & $\begin{array}{l}\text { and Clarkston basins } \\
\text { Pardee, 1925, p. } 22\end{array}$ & $\begin{array}{l}\text { Section on ridge, north } \\
\text { of Sixmile Creek, sec. }\end{array}$ & E-0 & 624 & 624 & 11 & 70 & - & - & yes & - & - & A & D & $\begin{array}{l}\text { coal in equiv. } \\
\text { beds } 2 \text { miles } \mathrm{SE} \\
\text { (Pardee, 1925, p. 23) }\end{array}$ & no \\
\hline 59 & Pardee, 1925, p. 25 & $\begin{array}{l}12 \mathrm{~T} .5 \mathrm{~N} ., \mathrm{R} .2 \mathrm{E} \text {. } \\
\text { Section north of Greyson } \\
\mathrm{Cr}, \text {, east line of sec. } \\
13, \mathrm{~T} .6 \mathrm{~N}, \mathrm{R} .2 \mathrm{E} \text {. }\end{array}$ & $\mathrm{M}-\mathrm{P}^{\mathrm{B}}$ & 575 & 575 & 23 & $1-50$ & NF & - & yes & - & - & - & D & & no \\
\hline 60 & Klemre, 1949, p. 191-196 & Section 20 , formation $A$ & $E-0$ & 2537 & 2537 & 27 & $2-36$ & - & - & yes & - & - & $\mathbf{A}$ & $\mathrm{s}$ & & no \\
\hline 61 & Klemene, 1949 , p. $188-191$ & Section 20 , formation B & $M-P$ & 2664 & 1664 & 65 & $15-470$ & - & - & yes & - & - & $\mathrm{T}$ & $\mathrm{s}$ & & yes \\
\hline
\end{tabular}

Dash means information not available.

$b_{M-P}$, Miocene and Pliocene; E-O, Eocene and Oligocene cMedium to coarse grained or conglomeratic.

$d_{N F}-0-10 \%$ feldspar: f1d - feldspathic; ark - arkosic
$e_{V}=$ very; $W=$ well $; M=$ moderate; $P=$ poor

$f_{P}=$ present but amount unknown; $T=$ trace $(<1 \%) ; A=$ accessory $(1 \%-10 \%)$; $S=$ subordinate $(10 \%-50 \%) ; D=$ dominant $(>50 \%)$

$\mathrm{g}_{\text {Age determined by subsequent }}$ Investigators. 
APPENDIX C

GAMMA-RAY SPECTROMETRIC ANALYSES OF ROCK SAMPLES 
GAMMA-RAY SPECTROMETRIC ANALYSES OF ROCK SAMPLES

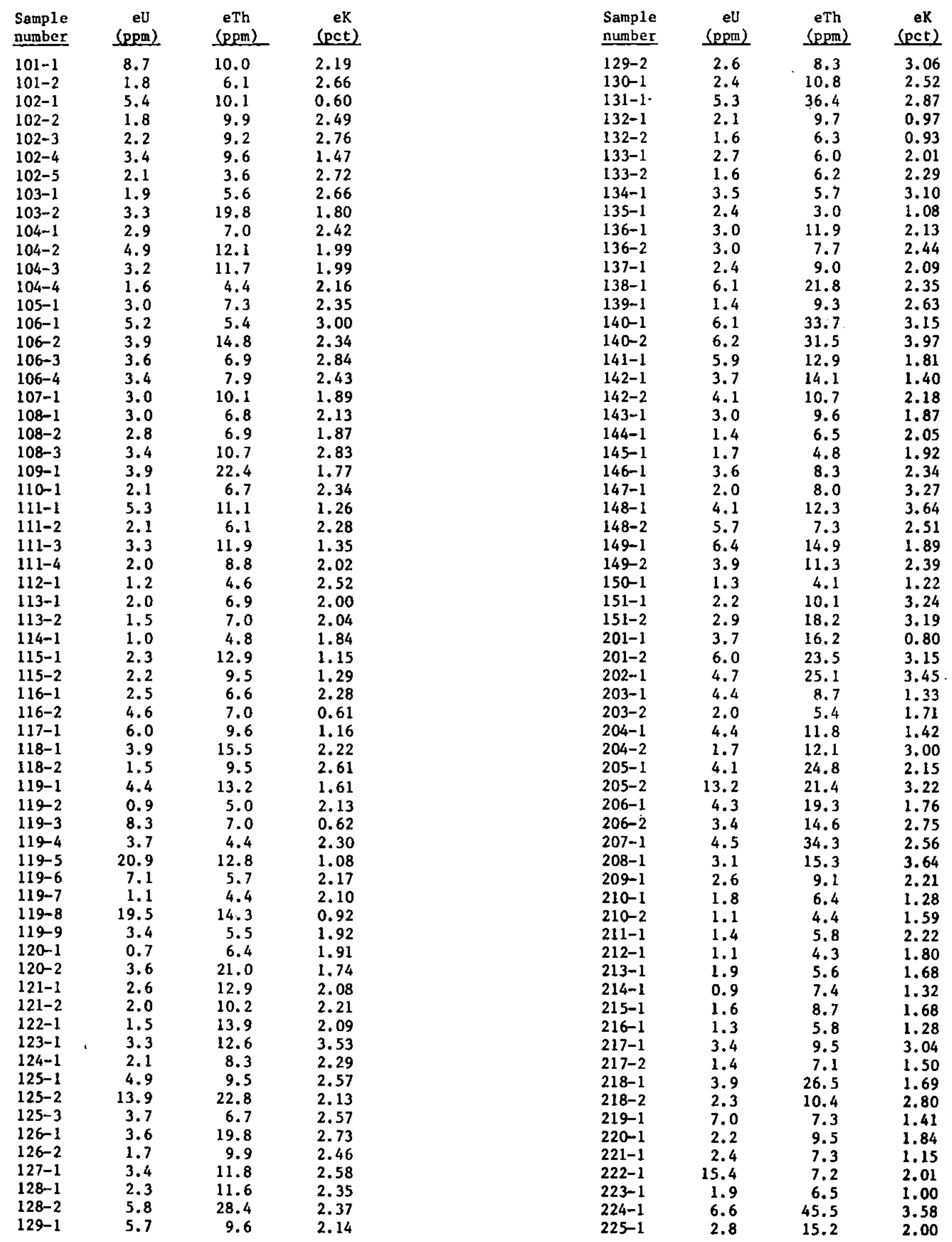


APPENDIX C (continued)

\begin{tabular}{|c|c|c|c|c|c|c|c|}
\hline $\begin{array}{l}\text { Sample } \\
\text { number }\end{array}$ & $\begin{array}{c}\mathrm{eU} \\
(\mathrm{ppm}) \\
\end{array}$ & $\begin{array}{c}\text { eTh } \\
\text { (ppm) }\end{array}$ & $\begin{array}{c}\mathrm{eK} \\
\text { (pct) }\end{array}$ & $\begin{array}{l}\text { Sample } \\
\text { number }\end{array}$ & $\begin{array}{c}\mathrm{eU} \\
\text { (ppm) }\end{array}$ & $\begin{array}{c}\text { eTh } \\
\text { (ppm) }\end{array}$ & $\begin{array}{c}\text { eK } \\
\text { (pct) } \\
\end{array}$ \\
\hline $225-2$ & 2.9 & 15.3 & 2.17 & $302-6$ & 25.8 & 11.3 & 2.79 \\
\hline $227-1$ & 4.1 & 21.8 & 3.51 & $302-7$ & 2.6 & 7.7 & 3.32 \\
\hline $227-2$ & 1.5 & 6.1 & 1.26 & $302-8$ & 4.8 & 9.1 & 2.93 \\
\hline $227-3$ & 1.8 & 10.5 & 1.50 & $302-9$ & 4.0 & 12.1 & 2.25 \\
\hline $227-4$ & 7.0 & 38.5 & 4.58 & $303-1$ & 40.6 & 69.5 & 2.73 \\
\hline $229-1$ & 2.2 & 9.4 & 2.96 & $303-2$ & 6.4 & 3.3 & 3.45 \\
\hline $229-2$ & 3.1 & 7.7 & 2.47 & $304-1$ & 7.7 & 23.3 & 1.61 \\
\hline $230-1$ & 5.6 & 30.2 & 4.40 & $304-2$ & 3.9 & 17.0 & 3.45 \\
\hline $231-1$ & 2.0 & 20.0 & 3.03 & $304-3$ & 14.6 & 79.2 & 2.15 \\
\hline $232-1$ & 4.8 & 12.5 & 1.65 & $304-4$ & 16.9 & 80.1 & 2.30 \\
\hline $232-2$ & 3.4 & 13.3 & 1.12 & $305-1$ & 5.8 & 11.1 & 2.79 \\
\hline $232-3$ & 2.1 & 9.5 & 1.92 & $305-2$ & 57.8 & 12.8 & 2.54 \\
\hline $233-1$ & 9.6 & 13.7 & 1.54 & $306-1$ & 7.4 & 12.7 & 3.05 \\
\hline $233-2$ & 3.6 & 3.6 & 2.35 & $309-1$ & 3.6 & 33.0 & 1.45 \\
\hline $234-1$ & 3.7 & 12.9 & 2.95 & $309-2$ & 2.3 & 15.9 & 2.95 \\
\hline 235-1 & 1.4 & 4.9 & 1.88 & $309-3$ & 11.5 & 39.0 & 3.33 \\
\hline $236-1$ & 2.7 & 1.4 & 1.84 & $310-1$ & 14.8 & 41.2 & 3.16 \\
\hline $237-1$ & 1.4 & 10.1 & 2.86 & $310-2$ & 13.9 & 14.9 & 1.72 \\
\hline $238-1$ & 107.0 & 13.3 & 1.65 & $310-3$ & 8.8 & 15.0 & 2.41 \\
\hline $239-1$ & 8.9 & 5.0 & 1.19 & $310-4$ & 9.3 & 24.2 & 2.85 \\
\hline $240-1$ & 3.4 & 14.7 & 2.77 & $311-1$ & 1.9 & 7.4 & 2.25 \\
\hline $240-2$ & 0.8 & 6.0 & 2.10 & $312-1$ & 303.4 & 10.6 & 0.02 \\
\hline $241-1$ & 0.3 & 4.6 & 0.50 & $312-2$ & 46.3 & 1.9 & 0.02 \\
\hline $242-1$ & 3.3 & 11.7 & 2.25 & $313-1$ & 1.3 & 17.0 & 1.56 \\
\hline $242-2$ & 1.8 & 9.8 & 2.43 & $313-2$ & 0.6 & 4.3 & 2.05 \\
\hline $243-1$ & 3.3 & 13.6 & 1.93 & $314-1$ & 4.7 & 11.3 & 2.68 \\
\hline $243-2$ & 1.9 & 5.4 & 1.00 & $314-2$ & 31.7 & 7.7 & 1.76 \\
\hline $244-1$ & 1.5 & 5.5 & 0.87 & $314-3$ & 3.1 & 10.6 & 2.11 \\
\hline $245-1$ & 1.8 & 35.4 & 3.71 & $314-4$ & 1.4 & 5.8 & 2.38 \\
\hline $246-1$ & 2.2 & 14.5 & 2.01 & $315-1$ & 3.6 & 10.8 & 2.77 \\
\hline $247-1$ & 0.8 & 2.7 & 0.25 & $315-2$ & 3.4 & 4.8 & 2.56 \\
\hline $248-1$ & 0.9 & 3.6 & 0.30 & $316-1$ & 2.7 & 10.6 & 2.79 \\
\hline $249-1$ & 2.4 & 5.8 & 0.41. & $316-2$ & 22.6 & 6.9 & 2.19 \\
\hline 249-2 & 8.2 & 29.0 & 2.82 & $316-3$ & 4.4 & 6.8 & 2. 58 \\
\hline $250-1$ & 26.6 & 12.7 & 4.57 & $316-4$ & 11.1 & 6.5 & 2.53 \\
\hline $251-1$ & 1.0 & 2.1 & 0.39 & $316-5$ & 6.6 & 7.6 & 2.37 \\
\hline $251-2$ & 1.8 & 1.3 & 0.22 & $317-1$ & 2.9 & 6.4 & 1.60 \\
\hline $251-3$ & -0.1 & 1.5 & 0.18 & $318-1$ & 85.6 & 25.2 & 1.39 \\
\hline $252-1$ & 0.6 & 0.8 & 0.08 & $318-2$ & 2.9 & 4.9 & 2.60 \\
\hline 253-1 & 1.5 & 5.4 & 1.33 & $320-1$ & 25.1 & 3.5 & 0.72 \\
\hline $254-1$ & 5.5 & 25.2 & 3.30 & $321-1$ & 69.8 & 15.8 & 2.44 \\
\hline $255-1$ & 1.3 & 5.2 & 0.81 & $322-1$ & 5.8 & 24.5 & 3.50 \\
\hline $255-2$ & 1.0 & 2.8 & 0.59 & $323-1$ & 9.5 & 49.5 & 3.06 \\
\hline $256-1$ & 0.8 & 4.6 & 1.05 & $324-1$ & 365.8 & 30.2 & 1.13 \\
\hline $257-1$ & 2.5 & 14.5 & 2.19 & $324-2$ & 466.7 & 30.9 & 2.23 \\
\hline $258-1$ & 4.0 & 13.1 & 2.50 & $324-3$ & 73.1 & 12.7 & 3.39 \\
\hline $260-1$ & 6.7 & 24.6 & 1.89 & $325-1$ & 9.5 & 19.7 & 1.81 \\
\hline $261-1$ & 3.8 & 11.5 & 2.65 & $325-2$ & 138.0 & 21.6 & 2.00 \\
\hline $261-2$ & 2.5 & 6.6 & 1.58 & $325-3$ & 155.0 & 21.5 & 1.59 \\
\hline $262-1$ & 1.7 & 12.2 & 1.58 & $325-4$ & 359.3 & 24.3 & 3.25 \\
\hline $262-2$ & 6.0 & 32.7 & 3.77 & $326-1$ & 49.8 & 33.8 & 2.36 \\
\hline $262-3$ & 2.4 & 14.0 & 1.34 & $326-2$ & 73.1 & 16.6 & 2.35 \\
\hline $262-4$ & 1.0 & 5.7 & 0.75 & $326-3$ & 4.0 & 9.9 & 3.33 \\
\hline $301-1$ & 7.9 & 9.8 & 3.28 & $327-1$ & 1.4 & 11.6 & 1.85 \\
\hline $301-2$ & 9.6 & 9.4 & 3.24 & $327-2$ & 1.6 & 10.0 & 1.91 \\
\hline $301-3$ & 4.5 & 15.0 & 2.71 & $328-1$ & 2.5 & 17.0 & 2.84 \\
\hline $301-4$ & 5.3 & 13.0 & 2.62 & $328-2$ & 1.5 & 12.1 & 3.22 \\
\hline $301-5$ & 3.8 & 12.7 & 2.42 & $329-1$ & 3.1 & 10.0 & 2.26 \\
\hline $301-6$ & 15.7 & 11.2 & 2.78 & $330-2$ & 604.4 & 42.1 & 2.57 \\
\hline $302-1$ & 11.9 & 7.6 & 2.98 & $330-3$ & 10.5 & 44.8 & 3.70 \\
\hline $302-2$ & 3.5 & 7.9 & 3.17 & $330-4$ & 25.3 & 47.5 & 3.90 \\
\hline $302-3$ & 2.3 & 5.8 & 3.53 & $331-1$ & 21.7 & 31.7 & 4.33 \\
\hline $302-4$ & 4.3 & 19.1 & 1.71 & $332-1$ & 17.7 & 55.7 & 3.68 \\
\hline $302-5$ & 6.1 & 18.9 & 1.60 & $333-1$ & 18.2 & 100.4 & 3.33 \\
\hline
\end{tabular}


APPENDIX C (continued)

$\begin{array}{lrrrr}\begin{array}{c}\text { Sample } \\ \text { number }\end{array} & \begin{array}{c}\mathrm{eU} \\ \text { (ppm) }\end{array} & \begin{array}{c}\mathrm{eTh} \\ \text { (ppm) }\end{array} & \begin{array}{c}\mathrm{eK} \\ \text { (pct) }\end{array} \\ 334-1 & 1.4 & 9.5 & 2.51 \\ 335-1 & 3.5 & 35.7 & 1.43 \\ 335-2 & 28.8 & 100.7 & 4.66 \\ 336-1 & 24.9 & 90.6 & 3.84 \\ 336-2 & 30.9 & 104.2 & 4.77 \\ 339-1 & 1.8 & 8.0 & 1.61 \\ 340-1 & 24.2 & 13.5 & 1.90 \\ 341-2 & 9.4 & 12.1 & 1.90 \\ 341-3 & 8.1 & 5.6 & 1.84 \\ 341-4 & 16.7 & 8.7 & 2.94 \\ 341-5 & 8.7 & 6.8 & 2.45 \\ 342-1 & 2.0 & 6.4 & 1.83 \\ 342-2 & 15.6 & 22.2 & 1.40 \\ 342-3 & 7.7 & 12.9 & 1.87 \\ 342-4 & 18.2 & 9.0 & 2.31 \\ 343-1 & 1.4 & 8.2 & 3.73 \\ 343-2 & 3.5 & 12.5 & 2.00 \\ 343-3 & 2.3 & 7.2 & 2.83 \\ 344-1 & 1.7 & 9.7 & 3.38 \\ 346-1 & 1.1 & 11.7 & 3.32 \\ 346-2 & 3.3 & 16.6 & 2.67 \\ 347-1 & 4.4 & 19.7 & 2.17 \\ 347-2 & 2.7 & 11.7 & 3.00\end{array}$

\begin{tabular}{|c|c|c|c|}
\hline $\begin{array}{l}\text { Sample } \\
\text { number }\end{array}$ & $\begin{array}{c}\mathrm{eU} \\
(\mathrm{ppm})\end{array}$ & $\begin{array}{c}\text { eTh } \\
\text { (ppm) }\end{array}$ & $\begin{array}{c}\mathbf{e K} \\
(p \subset t)\end{array}$ \\
\hline $347-3$ & 9.0 & 32.9 & 3.15 \\
\hline $348-1$ & 4.1 & 13.9 & 2.41 \\
\hline $348-2$ & 1.6 & 9.8 & 3.29 \\
\hline $349-1$ & 3.1 & 16.7 & 2.44 \\
\hline $349-2$ & 1.2 & 6.0 & 2.47 \\
\hline $349-3$ & 1.5 & 9.0 & 3.39 \\
\hline $350-1$ & 0.7 & 18.9 & 0.92 \\
\hline $350-2$ & 0.8 & 9.5 & 3.07 \\
\hline $353-1$ & 3.7 & 15.8 & 2.68 \\
\hline $353-2$ & 1.5 & 8.8 & 3.34 \\
\hline $354-1$ & 2.4 & 5.5 & 1.26 \\
\hline $354-2$ & 1.2 & 10.1 & 1.15 \\
\hline $355-1$ & 12.4 & 12.8 & 2.07 \\
\hline $358-1$ & 169.3 & 27.2 & 3.30 \\
\hline $358-2$ & 28.5 & 39.0 & 1.48 \\
\hline $359-1$ & 18.7 & 32.9 & 2.10 \\
\hline $359-2$ & 13.2 & 13.6 & 3.83 \\
\hline $359-3$ & 66.3 & 28.2 & 1.70 \\
\hline $359-4$ & 24.9 & 16.2 & 3.67 \\
\hline $360-1$ & 205.5 & 15.8 & 0.76 \\
\hline $360-2$ & 11.9 & 35.2 & 2.62 \\
\hline $360-3$ & 21.0 & 24.1 & 2.00 \\
\hline
\end{tabular}

NOTE: The relative precision of the equivalent uranium analyses at the 95 percent confidence level (1.95 standard deviation), based on eight analyses of two standards analyzed repeatedly throughout the project, is $0.6 \mathrm{ppm}$ at a mean level of $1.4 \mathrm{ppm}$ and $0.9 \mathrm{ppm}$ at a mean level of $3.7 \mathrm{ppm}$. The relative precision of the equivalent thorium analyses is $1.4 \mathrm{ppm}$ at a mean level of $1.8 \mathrm{ppm}$ and $1.7 \mathrm{ppm}$ at a mean level of $0.9 \mathrm{ppm}$. 
APPENDIX D

CHEMICAL URANIUM ANALYSES OF SELECTED ROCK SAMPLES 
APPENDIX D

CHEMICAL URANIUM ANALYSES OF SELECTED ROCK SAMPLES

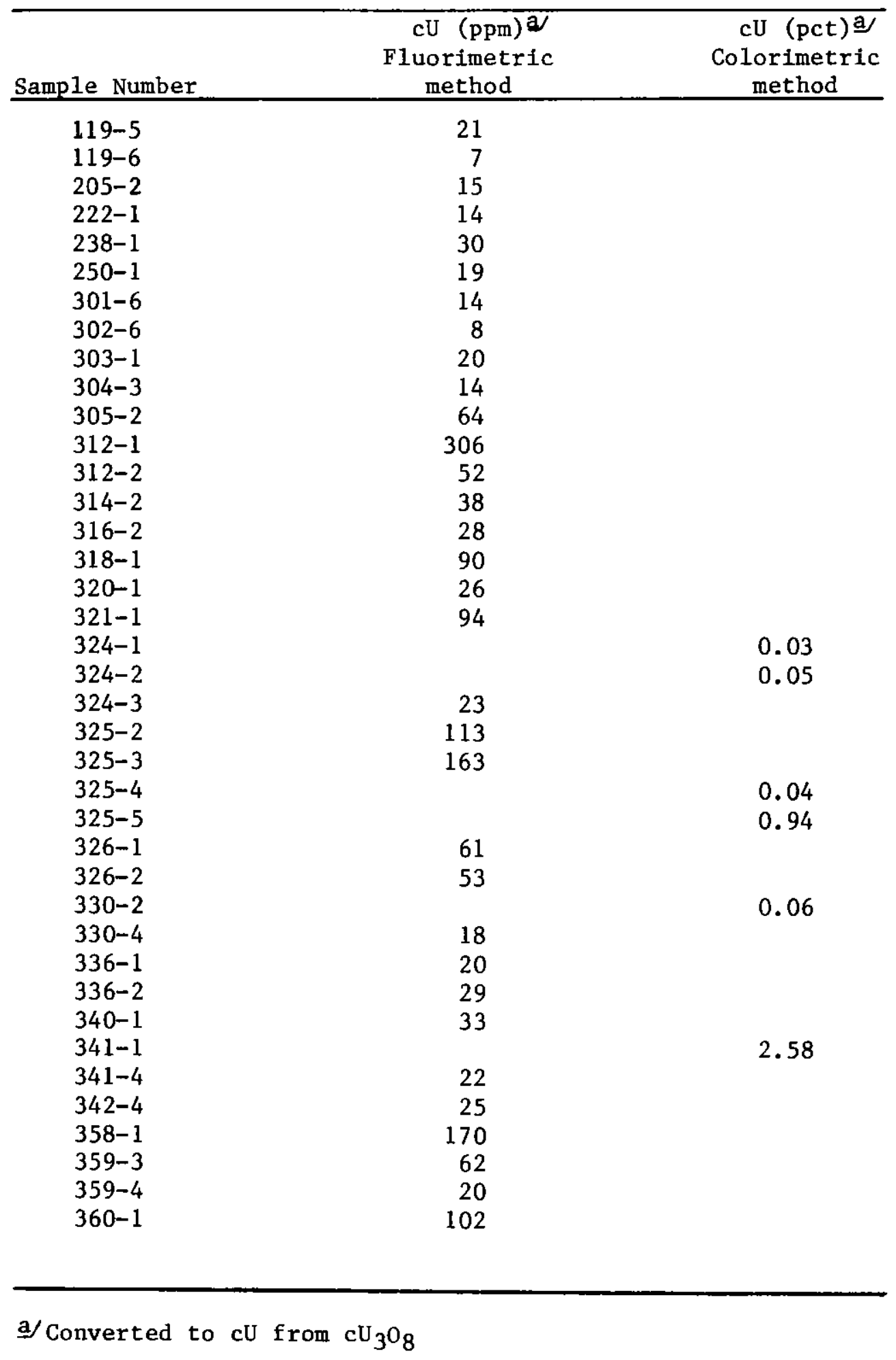




\section{APPENDIX E}

SEMIQUANTITATIVE EMISSION SPECTROSCOPIC ANALYSES OF SELECTED ROCK SAMPLES 
APPENDIX E

SEMIQUANTITATIVE EMISSION SPECTROSCOPIC ANALYSES OF SELECTED ROCK SAMPLES

(in percent)

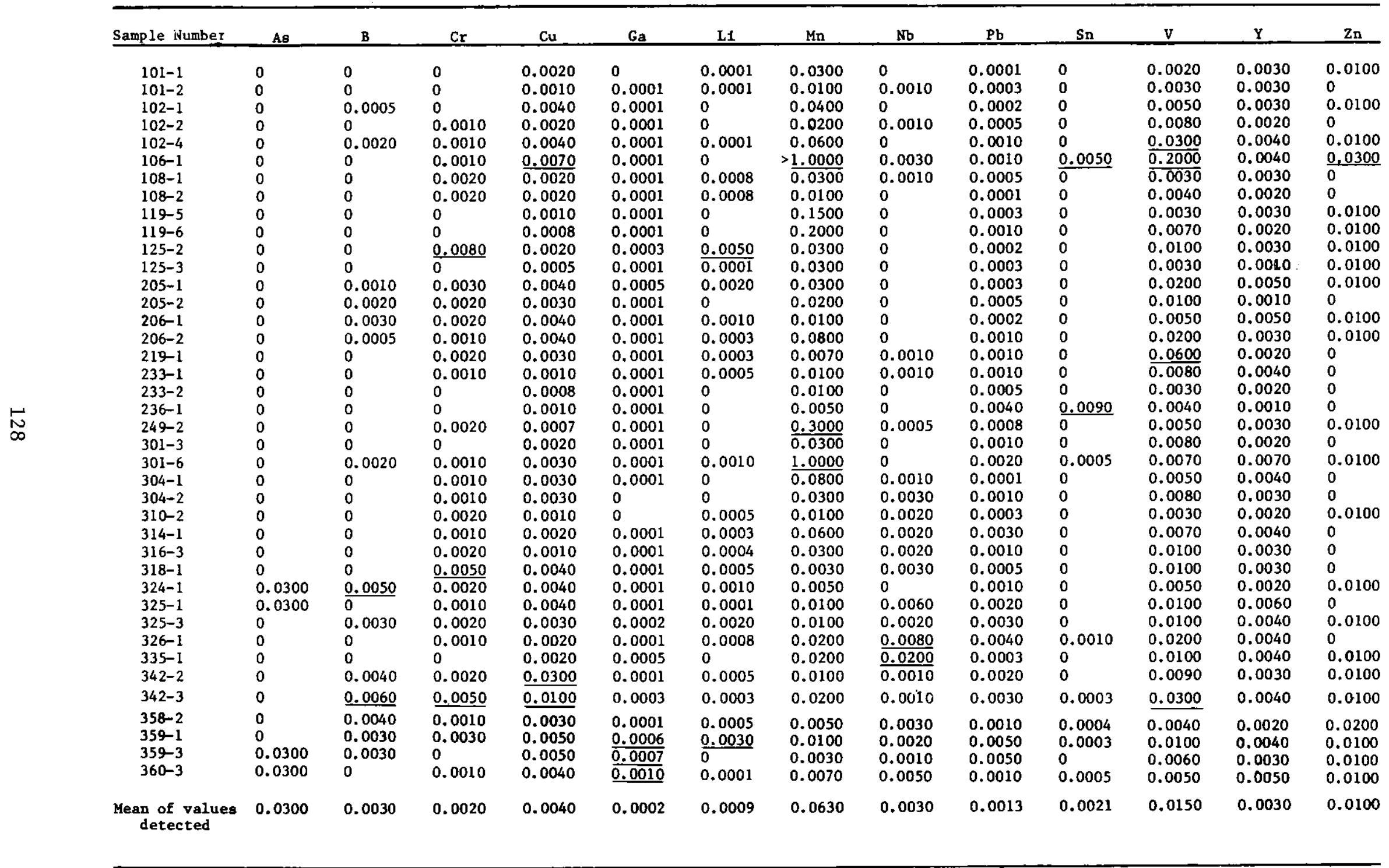

Note: zero value means not detected; underline means anomalous value. 
APPENDIX F

URANIUM ANALYSES OF WATER SAMPLES 


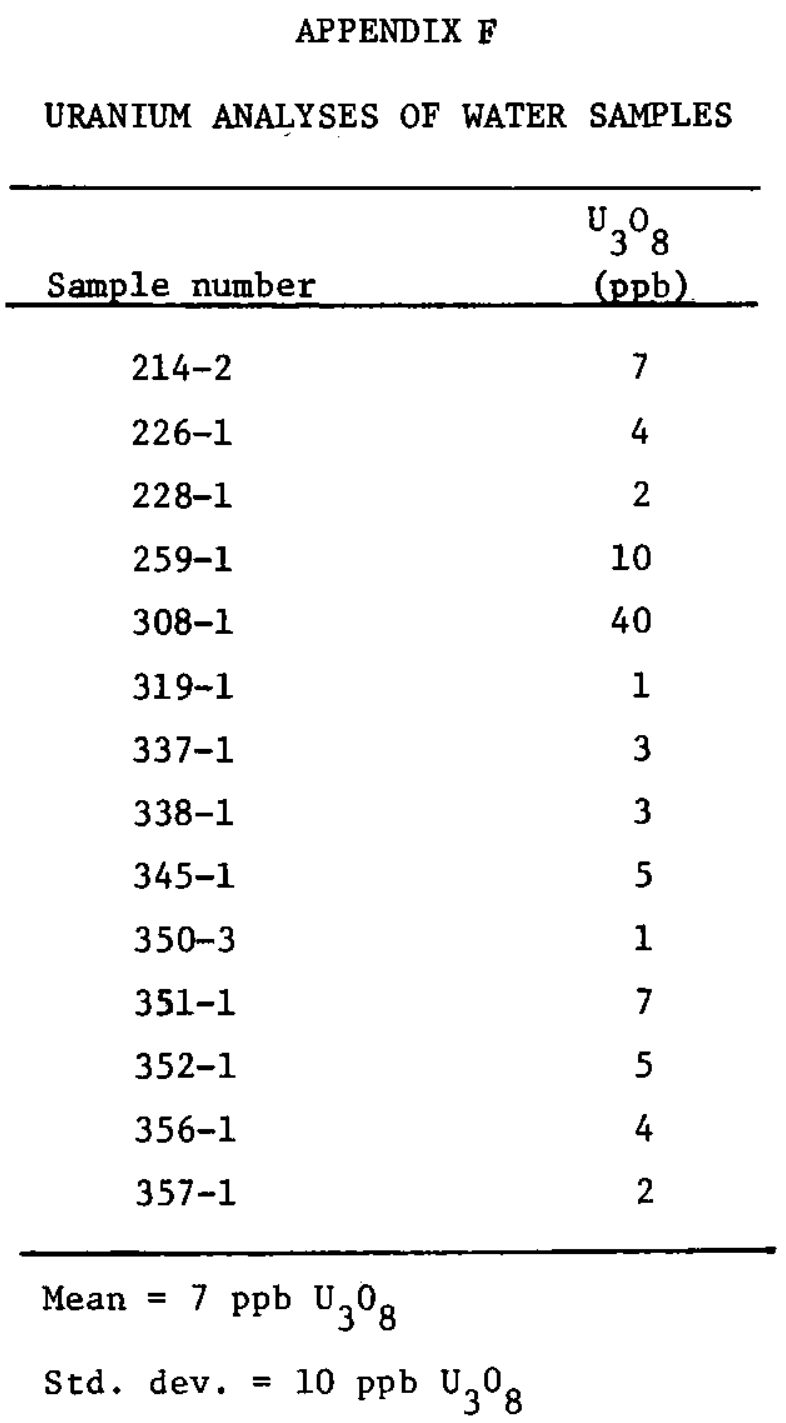


APPENDIX G

LIST OF PETROLEUM TEST WELLS 
APPENDIX G

LIST OF PETROLEUM TEST WELLS

\begin{tabular}{|c|c|c|c|c|c|c|c|}
\hline $\begin{array}{c}\text { Well } \\
\text { number }\end{array}$ & Company and well name & $\begin{array}{c}\text { Year } \\
\text { drilled } \\
\end{array}$ & Location & $\begin{array}{c}\text { Ground level } \\
\text { elev. (ft) }\end{array}$ & $\begin{array}{c}\text { Total } \\
\text { depth }(f t)\end{array}$ & $\begin{array}{l}\text { Depth to pre- } \\
\text { Tertiary rocks } \\
\text { (ft) }\end{array}$ & $\begin{array}{r}\text { Type of } \\
\text { los }(g) \\
\end{array}$ \\
\hline $1^{a}$ & $\begin{array}{l}\text { Ben Ryan } \\
\text { Tom Tice } 1\end{array}$ & -- & $\begin{array}{l}\text { NWbNWENW' oec. 28, T. } 1 \text { N., R. } 2 \text { E.; } \\
\text { Gallatin County }\end{array}$ & 4,180 & -- & 2,300 & -- \\
\hline 2 & $\begin{array}{l}\text { Montana Power Company; } \\
\text { Frances } \$ 2\end{array}$ & 1952 & $\begin{array}{l}\text { NWSWWANW/4 sec. 28, T. } 1 \text { N., R. } 2 \text { E.; } \\
\text { Gallatin County }\end{array}$ & 4,180 & 1,650 & -- & Elect, neutron \\
\hline 3 & $\begin{array}{l}\text { Montana Power Company; } \\
\text { Rice } 12\end{array}$ & - & $\begin{array}{l}\left.\text { CtrNE }{ }_{4 N E}\right\}_{4} \text { sec. } 29, \text { T. } 1 \text { N., R. } 2 \text { E.; } \\
\text { Gallatin County }\end{array}$ & 4,170 & 915 & -- & Gamma, neutron \\
\hline 4 & $\begin{array}{l}\text { Montana Power Company; } \\
\text { R1ce } \sharp 1\end{array}$ & 1952 & $\begin{array}{l}\text { SWB } \text { SB }_{4} \mathrm{NE}_{4}^{1} \text { sec. } 29, \text { T. } 1 \text { N., R. } 2 \text { E.; } \\
\text { Gallatin County }\end{array}$ & 4,180 & 1,182 & -- & Lith, elect \\
\hline 5 & $\begin{array}{l}\text { Dunbar } 011 \text { Company; } \\
\text { Dunbar \#1 }\end{array}$ & 1950 & $\begin{array}{l}\text { SEl }_{4}^{1} \mathrm{SW}_{2} \mathrm{SE}_{2}^{2} \text { sec. 8, T. } 2 \text { N., R. } 1 \text { E.; } \\
\text { Broadwater County }\end{array}$ & 4,065 & 2,124 & 1,661 & Lith \\
\hline 6 & $\begin{array}{l}\text { Elbert Malone; } \\
\text { Roger Hansen } 1\end{array}$ & 1960 & 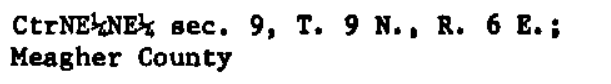 & 4,935 & 1,110 & 1,110 & Lith \\
\hline 7 & $\begin{array}{l}\text { Luhman and other } 8 ; \\
\text { Dunbar } 1\end{array}$ & 1947 & $\begin{array}{l}\text { Jef ferson County } \\
\text { Jef } 2 \text { N., R. } 1 \text { W.; }\end{array}$ & 4,840 & 1,260 & $1,214(?)$ & Lith \\
\hline 8 & $\begin{array}{l}\text { Montana Power Company; } \\
\text { State } 1-1-22\end{array}$ & 1961 & 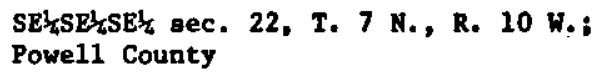 & 5,032 & 2,536 & -- & Elect, gamma \\
\hline 9 & $\begin{array}{l}\text { Buffalo ofl Company; } \\
\text { Nyhart } 1\end{array}$ & 1953 & $\begin{array}{l}\text { CtrNE } \frac{1}{4 N E} \frac{1}{6} \text { gec. } 3, \text { T. } 5 \text { s., R. } 7 \text { W.; } \\
\text { Mad18on County }\end{array}$ & $\begin{array}{l}4,800 \\
\text { est. }\end{array}$ & 2,633 & $2,175(?)$ & Lith \\
\hline 10 & $\begin{array}{l}\text { Farmers Union Central } \\
\text { Exchange; Stratigraph1c } \\
\text { Test } \$ 3\end{array}$ & 1971 & $\begin{array}{l}\text { NEXNEK sec, } 10, T, 7 \text { s., R. } 10 \text { W.; } \\
\text { Beaverhead County }\end{array}$ & 5,736 & 800 & -- & L1th \\
\hline 11 & $\begin{array}{l}\text { Farmers Union Central } \\
\text { Exchange; State } 11-16\end{array}$ & 1971 & 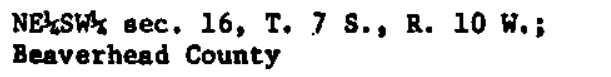 & 5,700 & 960 & -- & Lith \\
\hline 12 & $\begin{array}{l}\text { Beaverhead } 011 \text { and } \\
\text { Production Company; } \\
\text { Hanaen } 1\end{array}$ & 1955 & $\begin{array}{l}\text { CtrSWBSWF aec. 2, T. } 10 \mathrm{~s} ., \text { R. } 12 \mathrm{~W} \text {.; } \\
\text { Beaverhead County }\end{array}$ & 6,390 & 4,130 & -- & Elect \\
\hline 13 & $\begin{array}{l}\text { Able oul Company; } \\
\text { Monforton } 1\end{array}$ & 1954 & $\begin{array}{l}\text { NEל_SWAWty sec, 9, T. } 3 \text { s., R. } 4 \text { E.; } \\
\text { Gallatin County }\end{array}$ & 5,000 & 1,301 & 593 & Lith \\
\hline
\end{tabular}

Davis and others, 1965b, p. 3

bHackett and others, 1960 , p. 184-186 
APPENDIX $\mathrm{H}$

LIST OF WATER WELLS 
APPENDIX H

LIST OF WATER WELLS

\begin{tabular}{|c|c|c|c|c|c|c|c|c|}
\hline $\begin{array}{l}\text { Well } \\
\text { no. }\end{array}$ & Owner or tenant & Driller & $\begin{array}{c}\begin{array}{c}\text { Year } \\
\text { drilled }\end{array} \\
\end{array}$ & Location & County & $\begin{array}{r}\text { Est. } \\
\text { elev. } \\
\text { (ft) }\end{array}$ & $\begin{array}{c}\text { Total } \\
\text { depth } \\
\text { (ft) }\end{array}$ & $\begin{array}{l}\text { Depth to } \\
\text { pre-Tert. } \\
\text { (ft) }\end{array}$ \\
\hline $\begin{array}{l}1 \\
2 \mathrm{a} \\
3 \mathrm{a} \\
4 \mathrm{a}^{\mathrm{a}} \\
5 \\
6 \\
7 \\
8 \\
12 \\
13 \\
15 \\
17 \\
20 \\
22 \\
23 \\
24 \\
25 \\
26 \\
27 \\
28 \\
29 \\
30 \\
31 \\
32 \\
33 \\
34 \\
35 \\
36 \\
37 \\
38 \\
39 \\
40 \\
41 \\
42 \\
43 \\
44 \\
45^{\mathrm{a}} \\
46^{\mathrm{a}} \\
47^{\mathrm{a}} \\
48^{\mathrm{a}} \\
49^{\mathrm{a}} \\
50\end{array}$ & 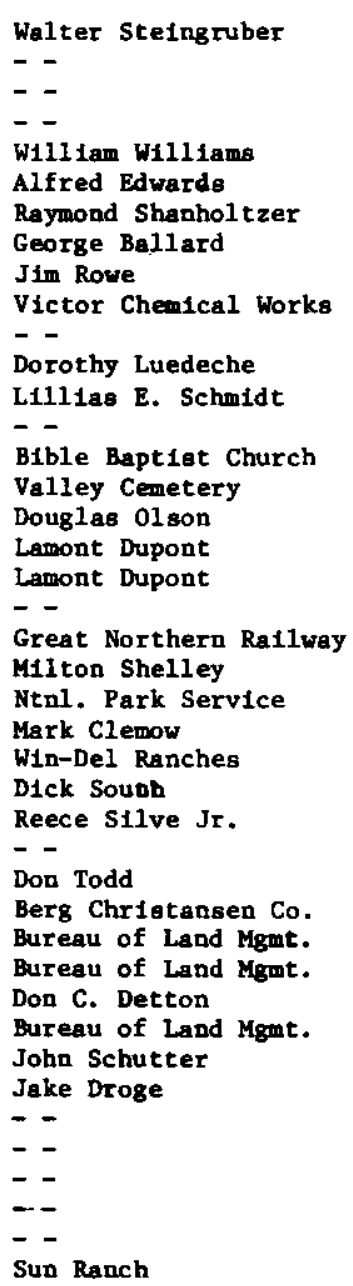 & 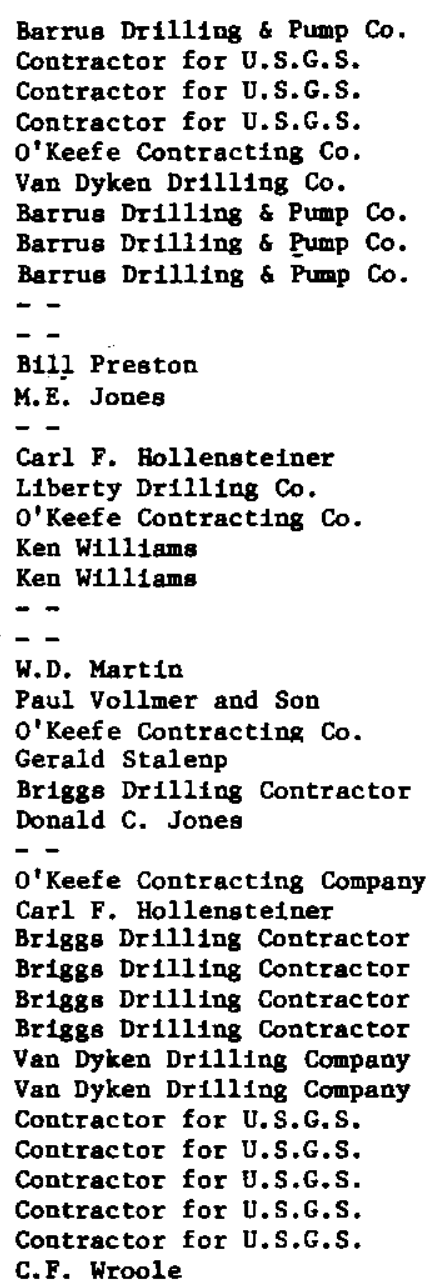 & $\begin{array}{l}1970 \\
-- \\
-- \\
-- \\
1974 \\
1963 \\
1970 \\
1970 \\
1972 \\
-- \\
-- \\
1973 \\
1968 \\
-- \\
1967 \\
1965 \\
1973 \\
1967 \\
1971 \\
-- \\
1943 \\
1972 \\
1965 \\
1975 \\
1962 \\
1973 \\
1970 \\
-- \\
1973 \\
1964 \\
1970 \\
1968 \\
1966 \\
1968 \\
1974 \\
1975 \\
-- \\
-- \\
-- \\
-- \\
-- \\
1959\end{array}$ & 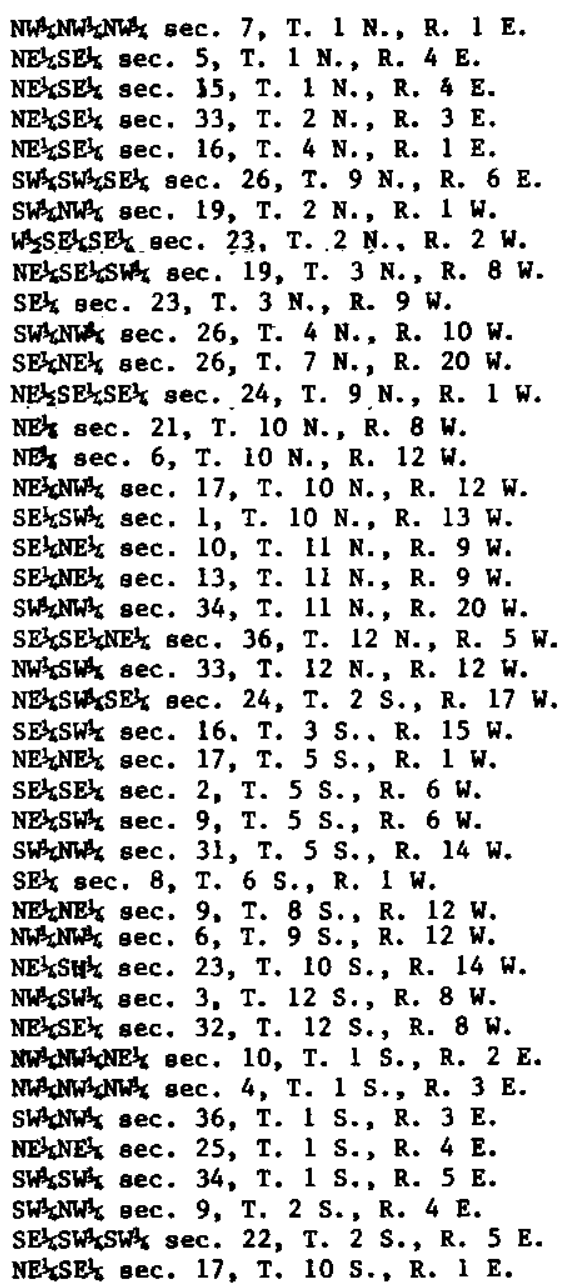 & $\begin{array}{l}\text { Broadwater } \\
\text { Gallatin } \\
\text { Gallatin } \\
\text { Gallatin } \\
\text { Broadwater } \\
\text { Meagher } \\
\text { Jefferson } \\
\text { Jefferson } \\
\text { Silver Bow } \\
\text { S1lver Bow } \\
\text { Deer Lodge } \\
\text { Ravalli } \\
\text { Broadwater } \\
\text { Powell } \\
\text { Granite } \\
\text { Granite } \\
\text { Granite } \\
\text { PowelI } \\
\text { Powill } \\
\text { Misoula } \\
\text { Lewis \& Clark } \\
\text { Powell } \\
\text { Beaverhead } \\
\text { Beaverhead } \\
\text { Madison } \\
\text { Madison } \\
\text { Madison } \\
\text { Beaverhead } \\
\text { Madison } \\
\text { Beaverhead } \\
\text { Beaverhead } \\
\text { Beaverhead } \\
\text { Beaverhead } \\
\text { Beaverhead } \\
\text { Gallatin } \\
\text { Gallatin } \\
\text { Gallatin } \\
\text { Gallatin } \\
\text { Gallatin } \\
\text { Gallatin } \\
\text { Gallatin } \\
\text { Madison }\end{array}$ & $\begin{array}{l}4,200 \\
4,250 \\
4,315 \\
4,200 \\
4,200 \\
4,970 \\
4,650 \\
4,840 \\
-- \\
-- \\
-- \\
-- \\
4,520 \\
-- \\
-- \\
4,200 \\
-- \\
-- \\
-- \\
-- \\
4,335 \\
-- \\
-= \\
6,145 \\
3,000 \\
-- \\
-- \\
-- \\
-- \\
-= \\
-Z \\
-- \\
-- \\
-7 \\
4,300 \\
4,540 \\
4,680 \\
4,575 \\
4,700 \\
4,890 \\
4,990 \\
--\end{array}$ & $\begin{array}{r}200 \\
207 \\
315 \\
450 \\
450 \\
300 \\
160 \\
195 \\
200 \\
400 \\
450 \\
450 \\
400 \\
400 \\
200 \\
125 \\
227 \\
120 \\
136 \\
135 \\
135 \\
250 \\
168\end{array}$ & 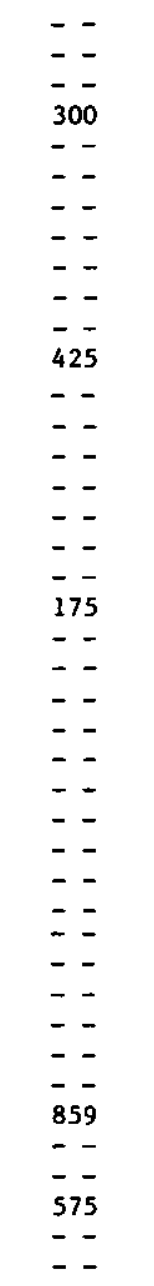 \\
\hline
\end{tabular}

- Backett and othere, 1960, p. 184-203 
APPENDIX I

COMPILATION OF DATA FROM URANIUM EXPLORATION DRILLING PROJECTS IN PARTS OF THE THREE FORKS, TOWNSEND, AND UPPER RUBY RIVER BASINS 
TABLE I-1. URANIUM EXPLORATION DRILL HOLES

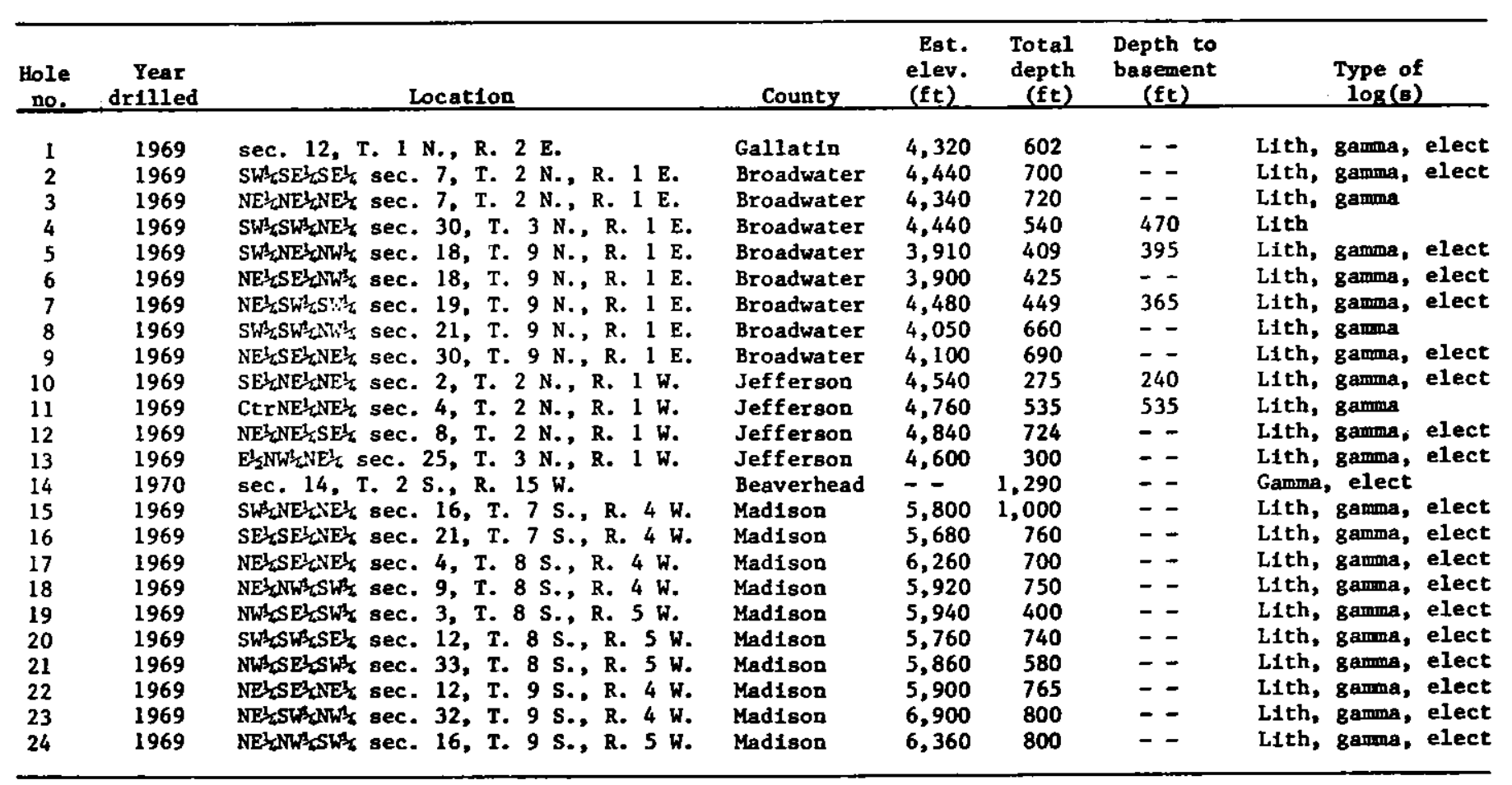


TABLE I-2, SUBSURFACE RADIOACTIVITY ANOMALIES IN PART

OF THE THREE FORKS BASIN

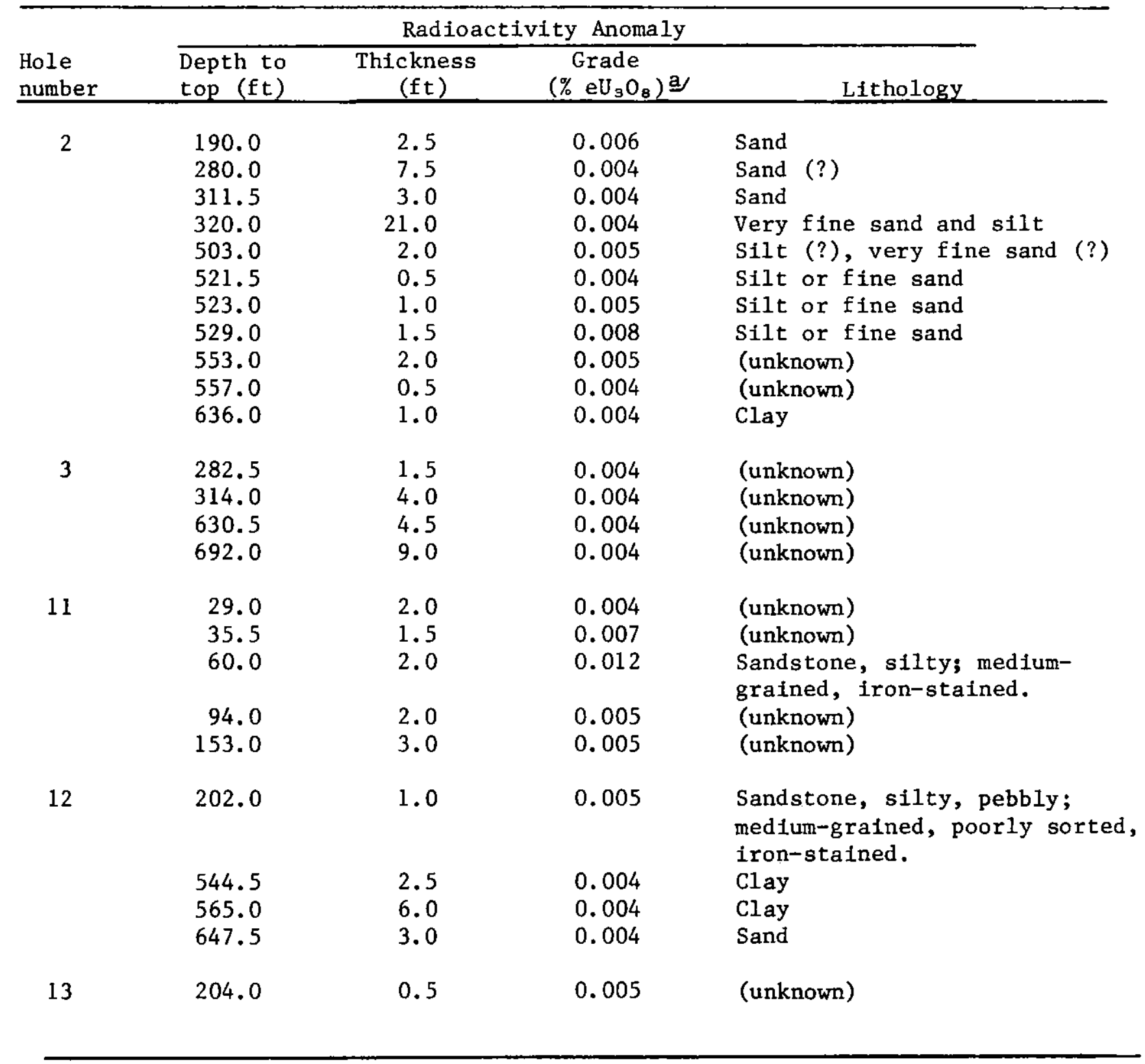

a/ Determined from gamma-ray $10 \mathrm{~g}$ using adaptation of method presented by Scott and others (1960, p. 21-25). Grade considered anomalous if greater than or equal to 0.004 percent. 


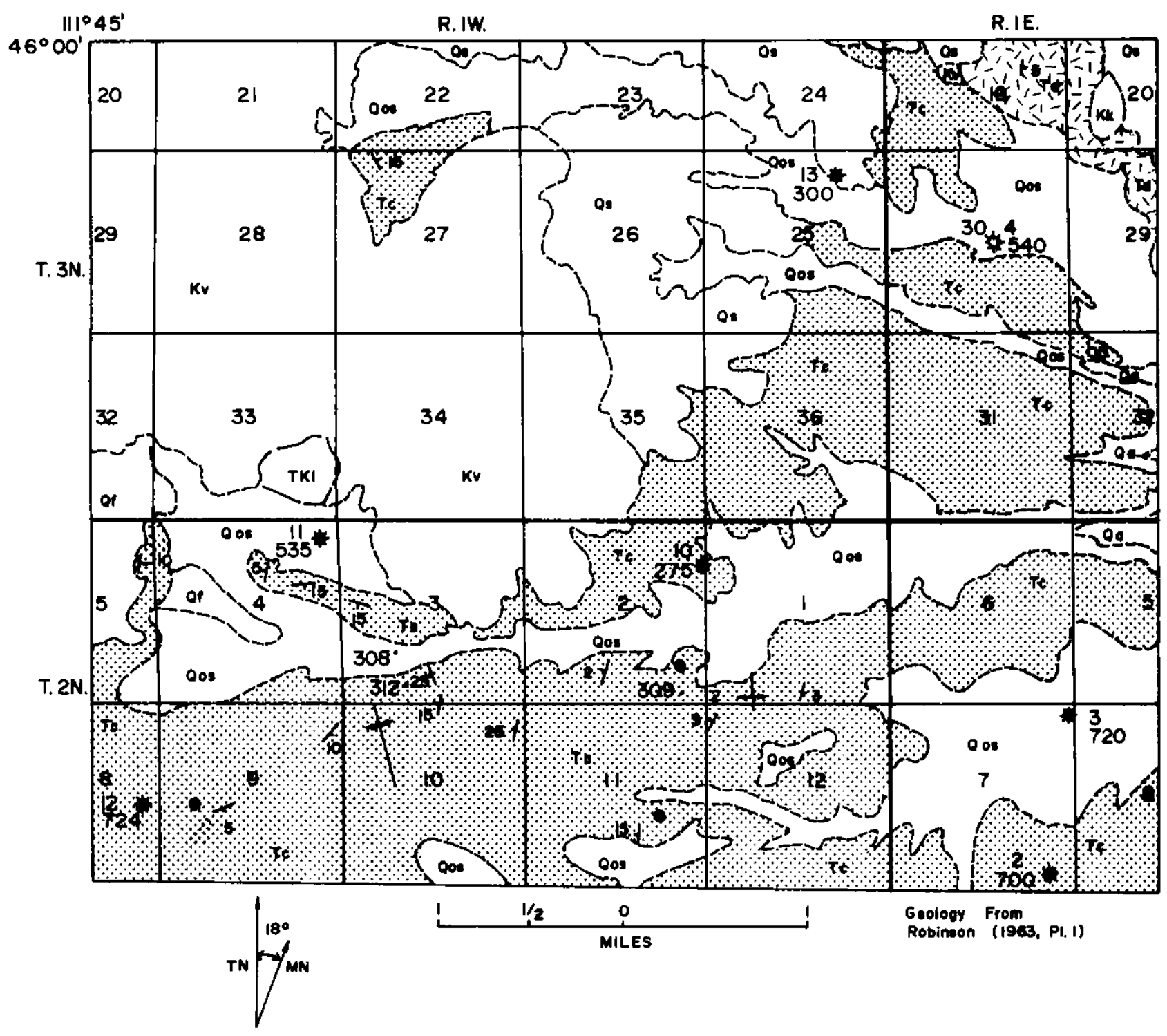

Figure I-1. Location of uranium exploration drill holes and study localities of part of the Three Forks basin. (See Pl. 2 for location of map area.) 


\section{EXPLANATION FOR FIGURE I-I}

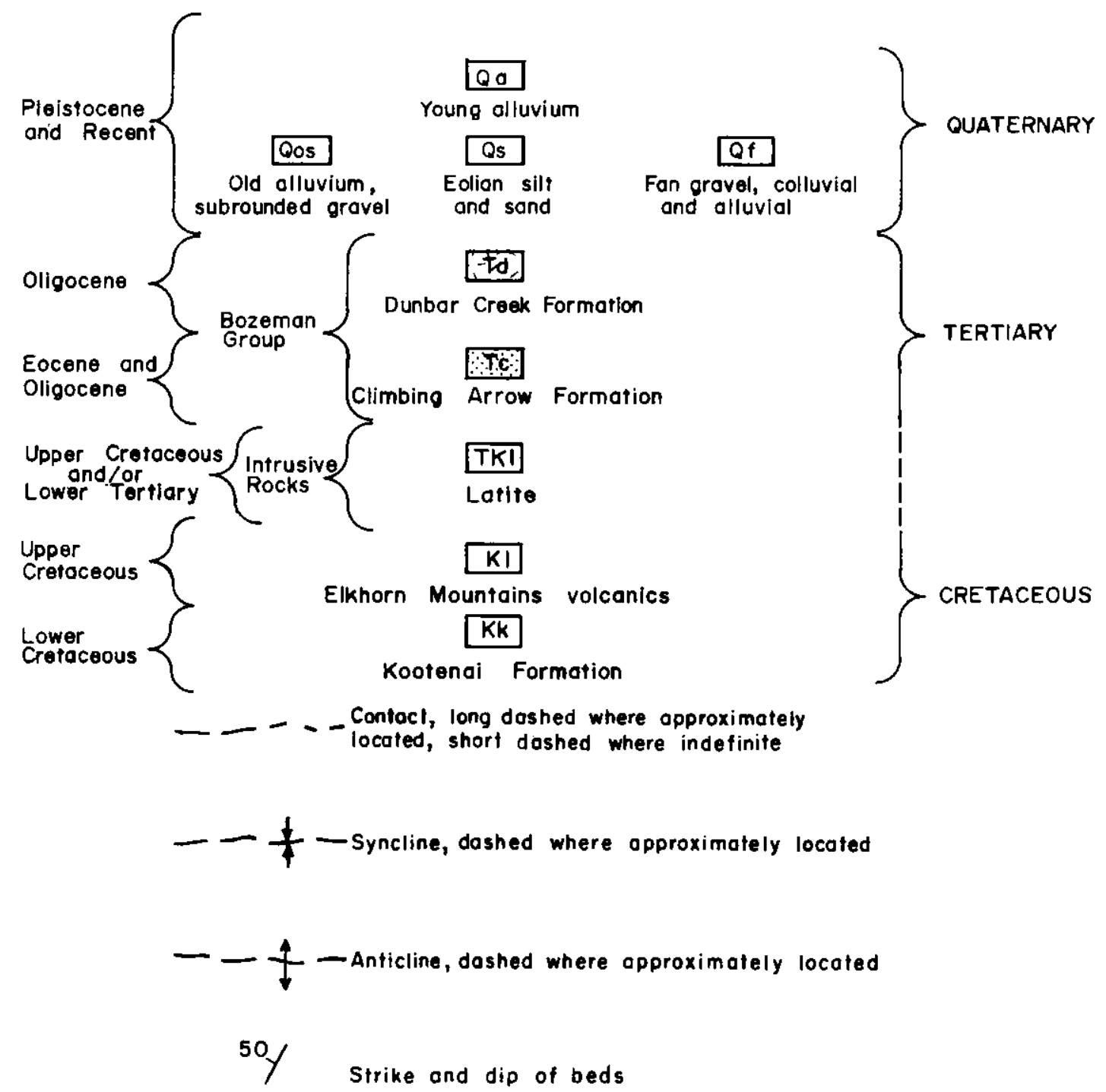

\section{$\bigoplus \quad$ Horizontol beds}

.312 Study locallty, with locality number (App. A).

\$540 Uranium exploration drill hole, gamma-ray log not avallable. Upper number is hole number, lower is total depth in feet (Table I-I).

ty Uranium exploration drill hole, no anomalies on gamma-ray log. Upper number is hole number, lower is total depth in teet (Table I-1).

*535 Uranium exploration drill hole, one or more anomalies on gamma-ray log (Table I-2). Upper number is hole number, lower is total depth in feet (Table $\mathrm{I}-1$ ). 


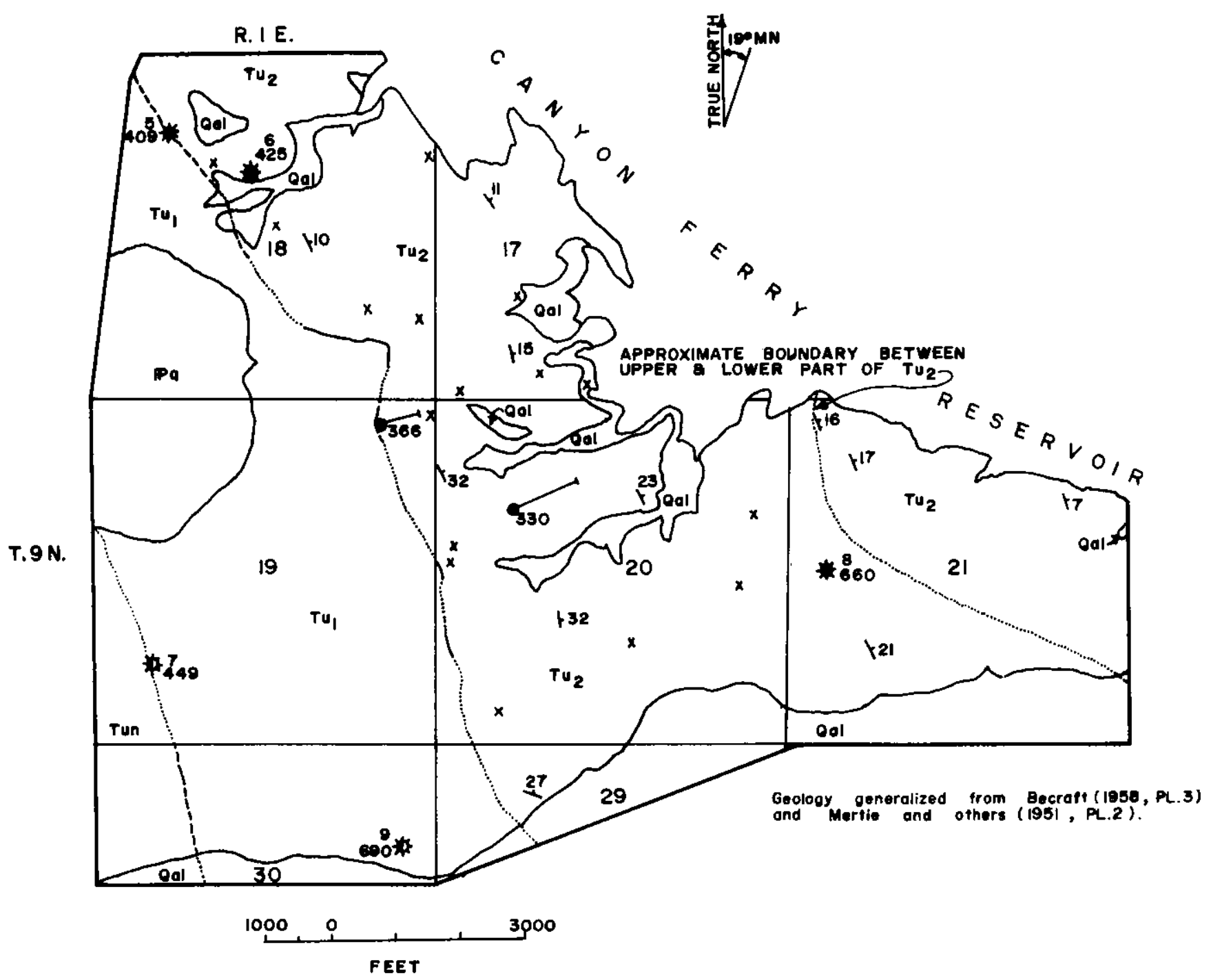

Figure I-2. Location of uranium exploration drill holes, surface radioactivity anomalies, and study localities of an area near Winston, Townsend basin. (See P1. 2 for location of map area.) 


\section{EXPLANATION FOR FIGURE I-2}

\section{Qol}

Alluvium
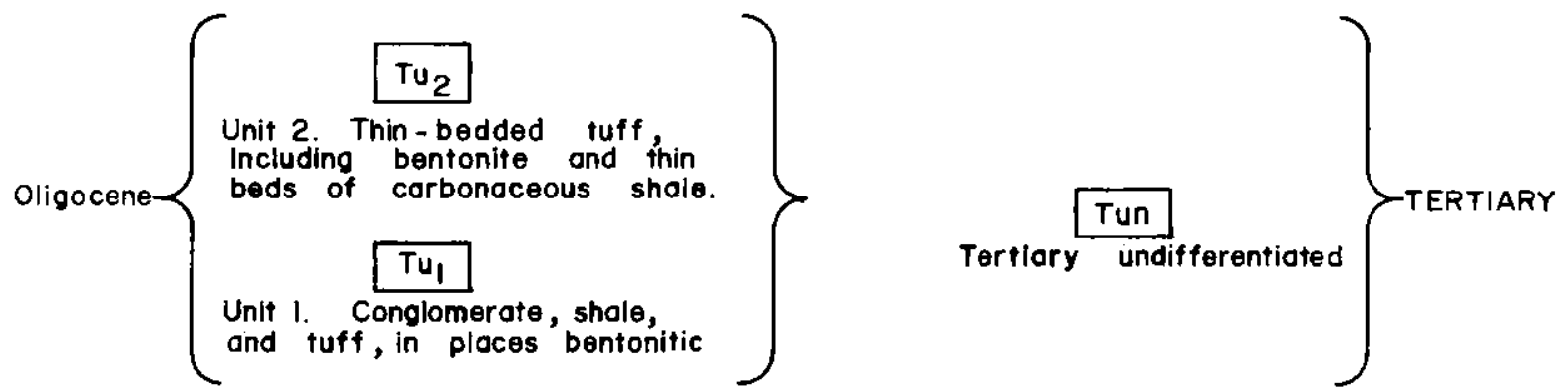

\section{$\mathbb{P q}$}

Quadrant formation undivided.

Quarizlte, in part interbedded

with limestone, sandstone, and

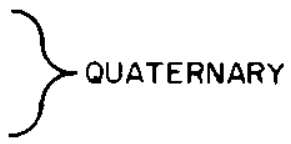

shale.

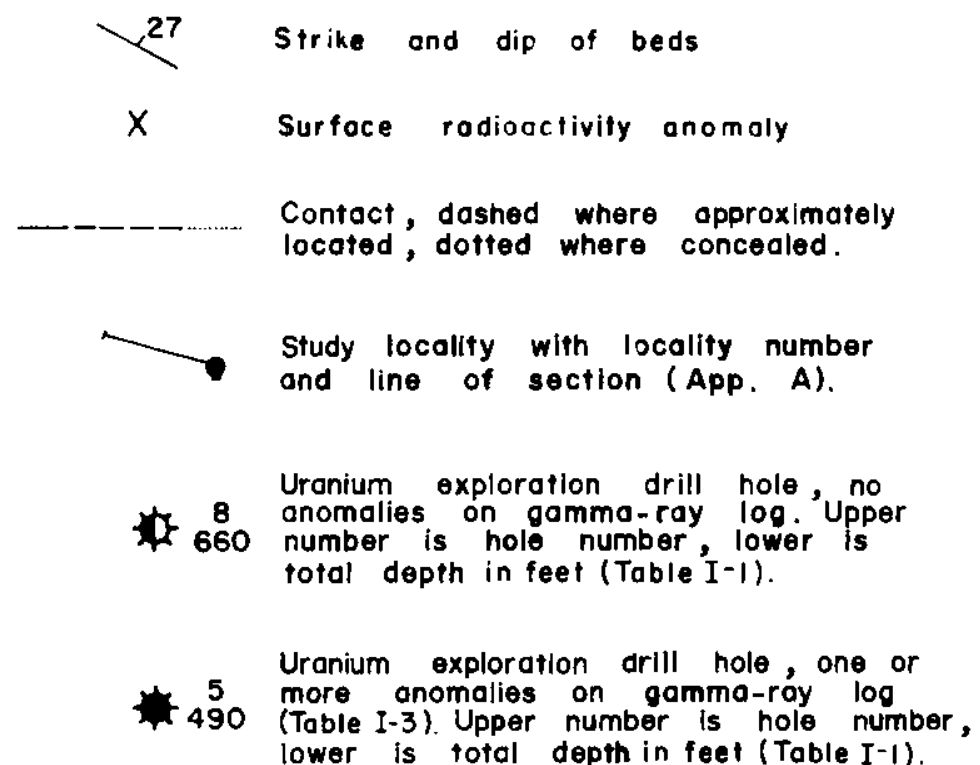


TABLE I-3. SUBSURFACE RADIOACTIVITY ANOMALIES IN AN AREA NEAR WINSTON, TOWNSEND BASIN

\begin{tabular}{|c|c|c|c|c|}
\hline \multirow[b]{2}{*}{$\begin{array}{l}\text { Hole } \\
\text { number }\end{array}$} & \multicolumn{3}{|c|}{ Radioactivity anomaly } & \multirow[b]{2}{*}{ Lithology } \\
\hline & $\begin{array}{l}\text { Depth to } \\
\text { top ( } \mathrm{ft} \text { ) }\end{array}$ & $\begin{array}{c}\text { Thickness } \\
(\mathrm{ft})\end{array}$ & $\begin{array}{c}\text { Grade } \\
\left(\% \quad \mathrm{eU}_{\mathrm{g}} \mathrm{O}_{\mathrm{Q}}\right) \mathrm{a}\end{array}$ & \\
\hline \multirow[t]{14}{*}{5} & 3 & 2.0 & 0.007 & (unknown) \\
\hline & 9.5 & 1.5 & 0.007 & (unknown) \\
\hline & 20.5 & 1.5 & 0.006 & (unknown) \\
\hline & 24.5 & 2.0 & 0.008 & (unknown) \\
\hline & 34.5 & 1.0 & 0.005 & (unknown) \\
\hline & 39.0 & 4.0 & 0.006 & $\begin{array}{l}\text { Sandstone, pumiceous, peb- } \\
\text { bly; coarse grained. }\end{array}$ \\
\hline & 51.0 & 0.5 & 0.004 & (unknown) \\
\hline & 62.5 & 1.0 & 0.004 & (unknown) \\
\hline & 70.5 & 1.5 & 0.004 & (unknown) \\
\hline & 81.5 & 2.0 & 0.008 & (unknown) \\
\hline & 119.0 & 0.5 & 0.005 & (unknown) \\
\hline & 136.5 & 1.0 & 0.005 & (unknown) \\
\hline & 157.5 & 1.0 & 0.006 & (unknown) \\
\hline & 216.5 & 1.0 & 0.005 & (unknown) \\
\hline \multirow[t]{11}{*}{6} & 49.0 & 1.5 & 0.004 & (unknown) \\
\hline & 55.0 & 4.0 & 0.006 & (unknown) \\
\hline & 65.5 & 3.0 & 0.005 & (unknown) \\
\hline & 86.0 & 2.0 & 0.011 & (unknown) \\
\hline & 94.5 & 1.5 & 0.008 & (unknown) \\
\hline & 98.0 & 1.0 & 0.007 & (unknown) \\
\hline & 174.5 & 1.5 & 0.011 & (unknown) \\
\hline & 180.0 & 3.0 & 0.006 & (unknown) \\
\hline & 188.0 & 1.0 & 0.012 & (unknown) \\
\hline & 233.0 & 9.0 & 0.005 & (unknown) \\
\hline & 261.0 & 21.5 & 0.004 & Volcanic ash \\
\hline \multirow[t]{12}{*}{8} & 259.0 & 1.5 & 0.000 & (unknown) \\
\hline & 270.0 & 2.5 & 0.005 & (unknown) \\
\hline & 591.0 & 1.0 & 0.007 & (unknown) \\
\hline & 599.0 & 2.0 & 0.007 & (unknown) \\
\hline & 607.0 & 1.5 & 0.004 & (unknown) \\
\hline & 612.5 & 1.0 & 0.014 & (unknown) \\
\hline & 615.0 & 1.5 & 0.008 & (unknown) \\
\hline & 623.0 & 1.5 & 0.008 & (unknown) \\
\hline & 625.5 & 1.0 & 0.005 & (unknown) \\
\hline & 639.5 & 1.0 & 0.005 & (unknown) \\
\hline & 645.5 & 1.0 & 0.004 & (unknown) \\
\hline & 651.0 & 3.0 & 0.006 & (unknown) \\
\hline
\end{tabular}

a/ Determined from gamma-ray $\log$ using adaptation of method presented by Scott and others (1960, p. 21-25). Grade considered anomalous if greater than or equal to 0.004 percent. 
TABLE I-4. SUBSURFACE RADIOACTIVITY ANOMALIES IN PART OF THE UPPER RUBY RIVER BASIN

\begin{tabular}{lccll}
\hline & \multicolumn{4}{c}{ Radioactivity Anomaly } \\
\cline { 2 - 4 } $\begin{array}{l}\text { Hole } \\
\text { number }\end{array}$ & $\begin{array}{c}\text { Depth to } \\
\text { top }(\mathrm{ft})\end{array}$ & $\begin{array}{c}\text { Thickness } \\
(\mathrm{ft})\end{array}$ & $\begin{array}{c}\text { Grade } \\
\left(\% \mathrm{eU}_{3} \mathrm{O}_{\mathrm{B}}\right)\end{array}$ & \multicolumn{1}{c}{ aj } \\
16 & 48 & 1.5 & 0.004 & Clay cemented gravel \\
20 & 63 & 5.0 & 0.004 & $\begin{array}{l}\text { (unknown) } \\
\text { (unknown) }\end{array}$ \\
21 & 79 & 6.0 & 0.005 & Silty sandstone \\
23 & 265 & 2.0 & 0.010 & Volcanic ash
\end{tabular}

a/ Determined from gamma-ray $\log$ using adaptation of method presented by Scott and others (1960, p. 21-25). Grade considered anomalous if greater than or equal to 0.004 percent. 


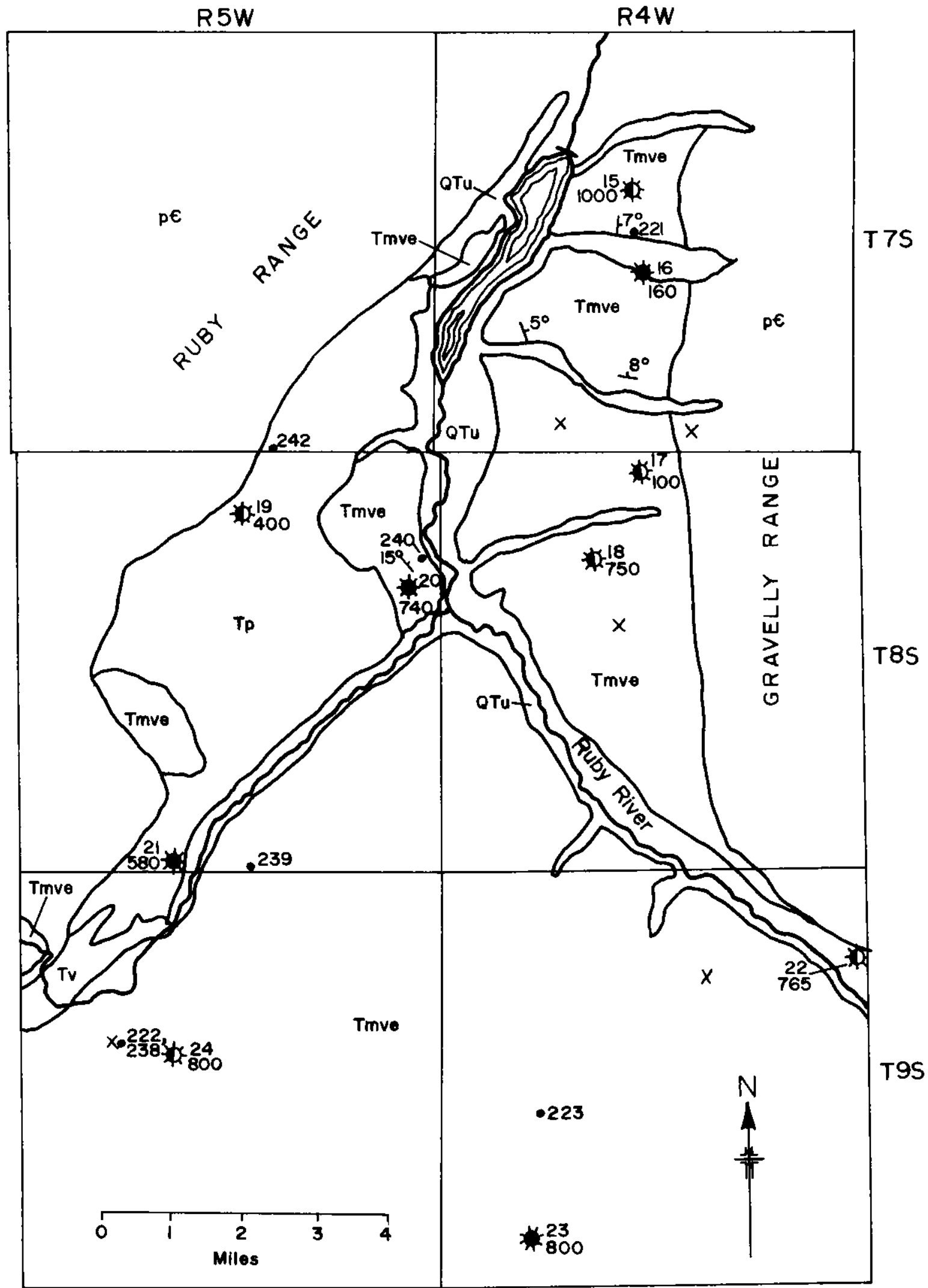

Figure I-3. Location map of uranium exploration drill holes, surface radioactivity anomalies, and study localities of part of the Upper Ruby River basin. (See P1. 2 for location of map area.) 


\section{EXPLANATION FOR FIGURE I-3}
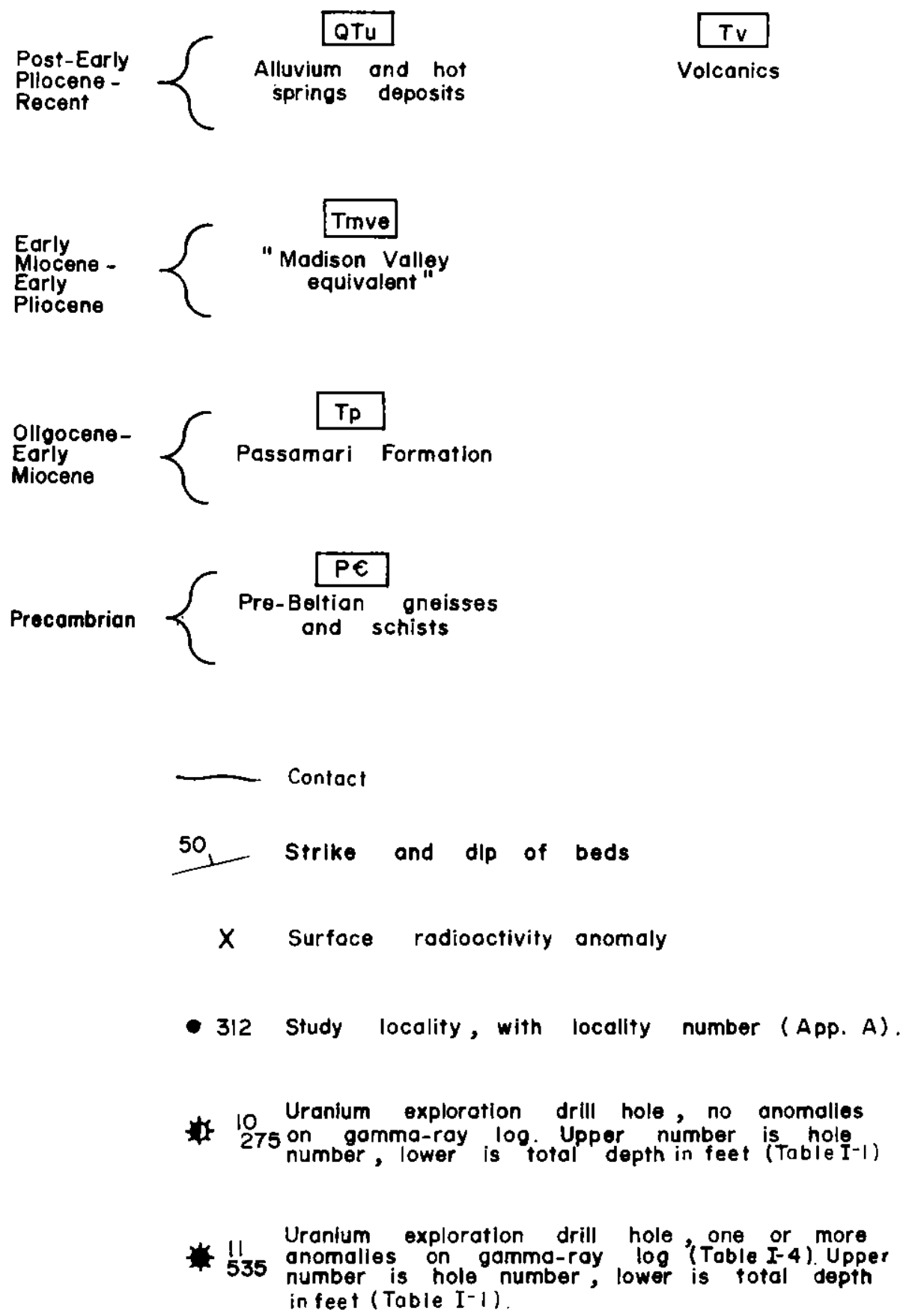

APPENDIX J

URANIUM OCCURRENCES DESCRIBED

IN PUBLISHED AND OPEN-FILED REPORTS 
APPENDIX J. URANIUM OCCURRENCES DESCRIBED IN PUBLISHED AND OPEN-FILED REPORTS

\begin{tabular}{|c|c|c|c|}
\hline $\begin{array}{c}\text { Identification } \\
\text { no. }\end{array}$ & Location & Reference & $\begin{array}{r}\text { Number of } \\
\text { occurrences }\end{array}$ \\
\hline$I$ & $\begin{array}{l}\text { Secs. } 17,18,20,21,28 \text {, and } 34, \mathrm{~T} . \\
9 \text { N., R. } 1 \text { E.; Broadwater County }\end{array}$ & $\begin{array}{l}\text { Becraft, 1958, p. 152-159, } \\
\text { P1. } 3\end{array}$ & 21 \\
\hline 2 & $\begin{array}{l}\text { On east-west section line between } \\
\text { secs. } 1 \text { and } 2 \text { and secs. } 11 \text { and } 12 \text {, } \\
\text { T. } 2 \text { N., R. } 1 \text { W.; Jefferson County }\end{array}$ & $\begin{array}{l}\text { Becraft, } 1958, \text { p. 162-163, } \\
\text { Fig. } 19\end{array}$ & 2 \\
\hline 3 & $\begin{array}{l}\text { Secs. } 2 \text { and } 10, \underset{T}{\mathrm{~T}} ; 2 \text { N., R. } 1 \text { W.; } \\
\text { Jefferson County }\end{array}$ & Pruitt, I955b & 1 \\
\hline 4 & $\begin{array}{l}\text { Sec. } 22, \text { T. } 2 \text { N., R. } 5 \text { W.; } \\
\text { Jefferson County }\end{array}$ & Moen and Hetland, 1953 & 1 \\
\hline 5 & $\begin{array}{l}\text { Secs. } 1,2 \text {, and } 3, \text { T. } 3 \text { N., R. } 1 \text { W.; } \\
\text { Jefferson County }\end{array}$ & $\begin{array}{l}\text { Becraft, 1958, p. 161-162, } \\
\text { Fig. } 18\end{array}$ & 4 \\
\hline 6 & $\begin{array}{l}\text { Sec. } 31, \text { T. } 3 \text { N., R. } 1 \text { W.; } \\
\text { Jefferson County }\end{array}$ & Jarrard, 1955 & 1 \\
\hline 7 & $\begin{array}{l}\text { Secs. } 28 \text { and } 29, \text { T. } 11 \text { N., R. } 2 \text { W.; } \\
\text { Lewis and Clark County }\end{array}$ & $\begin{array}{l}\text { Becraft, 1958, p. 160-161, } \\
\text { Fig. } 17\end{array}$ & 4 \\
\hline 8 & $\begin{array}{l}\text { Sec. } 17, \text { T. } 9 \text { S., R. } 5 \text { W.; } \\
\text { Madison County }\end{array}$ & $\begin{array}{l}\text { Jarrard and VanAlstine, } \\
1954\end{array}$ & 1 \\
\hline 9 & $\begin{array}{l}\text { Sec. } 18, \text { T. } 10 \text { S., R. } 13 \text { W.; } \\
\text { Beaverhead County }\end{array}$ & Pruitt, 1955a & 1 \\
\hline
\end{tabular}

a/ Location provided by authors of the present report; location given in cited reference is in correct. 
APPENDIX $\mathrm{K}$

RESULTS OF URANIUM DISEQUILIBRIUM STUDIES 
The equivalent uranium (eU) and chemical uranium (cU) values from 37 selected rock samples were plotted on Figure $\mathrm{K}-1$ in order to ascertain which of the samples, if any, were in disequilibrtum. For the purposes of this report, a sample is considered to be in disequilibrium if it plots clearly outside of the 99 percent confidence envelope of analytical precision. A sample is considered to be in possible disequilibrium if it plots on the edge or barely outside of the 99 percent confidence envelope. Table $\mathrm{K}-1$ shows the distribution of the selected rock samples by basin and by degree of disequilibrium.

of the 37 samples 6 are in disequilibrium and 7 are in possible disequilibrium. All 6 samples in disequilibrium and 3 samples in possible disequilibrium exhibit eU values that are higher than their respective cU values. Of these 9 samples 5 are from the western part of the Three Forks basin, and 1 each of the remaining 4 samples is from the Townsend, Helena, Upper Ruby River, and Horse Prairle basins, respectively.

The other 4 samples, of the 7 that are in posstble disequilibrium, exhibit eU values which are lower than their respective cU values. Of these 4 samples 3 are from the western part of the Three Forks basin and 1 is from the clarkston basin. 


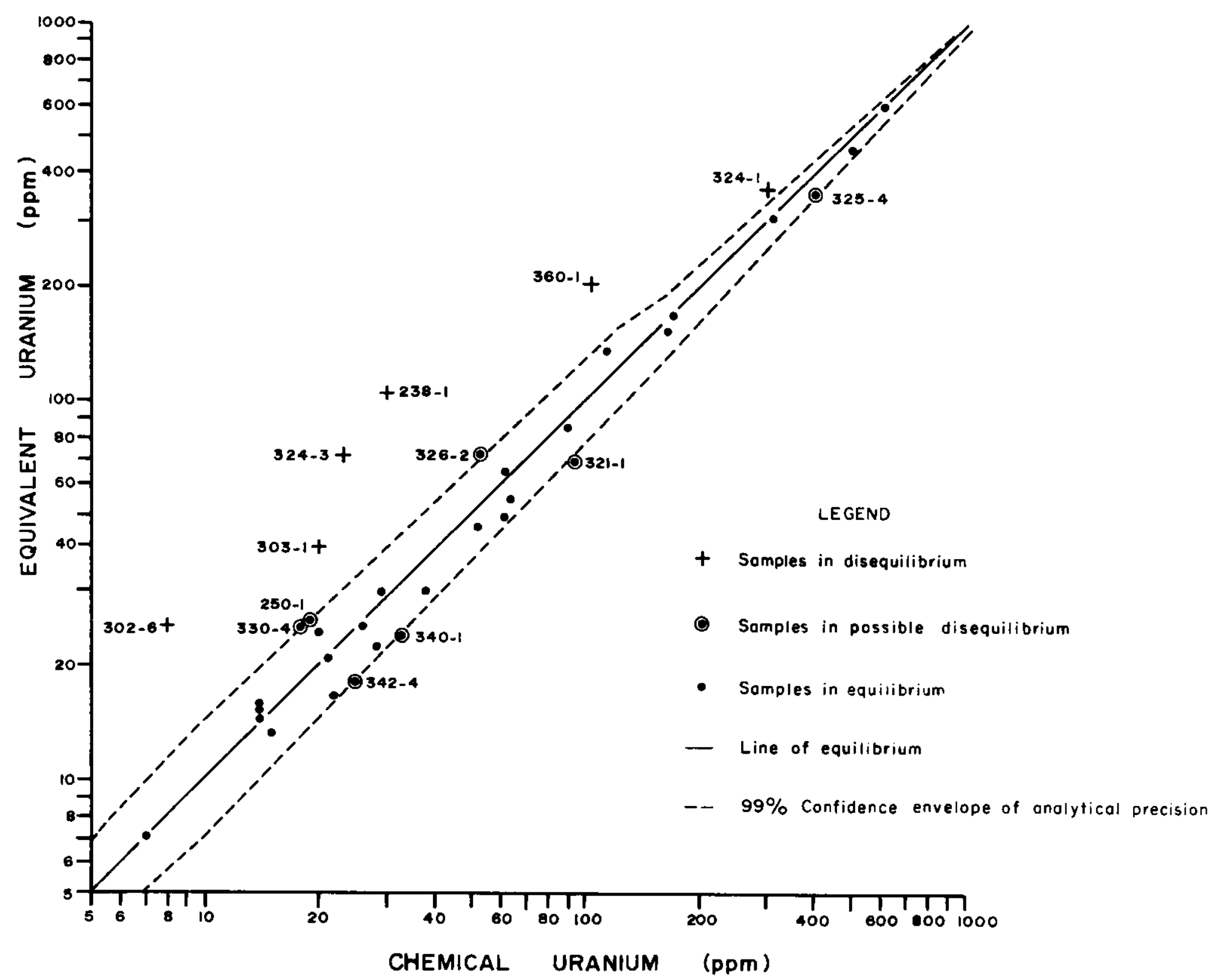

Figure K-1. Plot of chemical uranium versus equivalent uranium for selected samples from southwestern Montana. 
TABLE K-1. DISTRIBUTION OF SAMPLES ANALYZED FOR URANIUM DISEQUILIBRIUM, BY AREA AND DEGREE OF DISEQUILIBRIUM

\begin{tabular}{|c|c|c|c|}
\hline Basin(s) & $\begin{array}{c}\text { Number } \\
\text { analyzed }\end{array}$ & $\begin{array}{c}\text { Number in } \\
\text { disequilibrium }\end{array}$ & $\begin{array}{l}\text { Number in } \\
\text { possible } \\
\text { disequilibrium }\end{array}$ \\
\hline Three Forks basin, western part & 20 & 4 & 4 \\
\hline Three Forks basin, eastern part & 1 & 0 & 0 \\
\hline Townsend and Clarkston basins & 4 & 0 & 2 \\
\hline Helena basin & 4 & 1 & 0 \\
\hline Smith River basin & 2 & 0 & 0 \\
\hline $\begin{array}{l}\text { Jefferson, Beaverhead, and Lower } \\
\text { Ruby River basins }\end{array}$ & 1 & 0 & 0 \\
\hline Upper Ruby River basin & 2 & 1 & 0 \\
\hline $\begin{array}{l}\text { Grasshopper Creek, Horse Prairie } \\
\text { Medicine Lodge Creek, and Big } \\
\text { Sheep Creek basins }\end{array}$ & 1 & 0 & 1 \\
\hline Big Hole River basin & 2 & 0 & 0 \\
\hline Total number & 37 & 6 & 7 \\
\hline
\end{tabular}




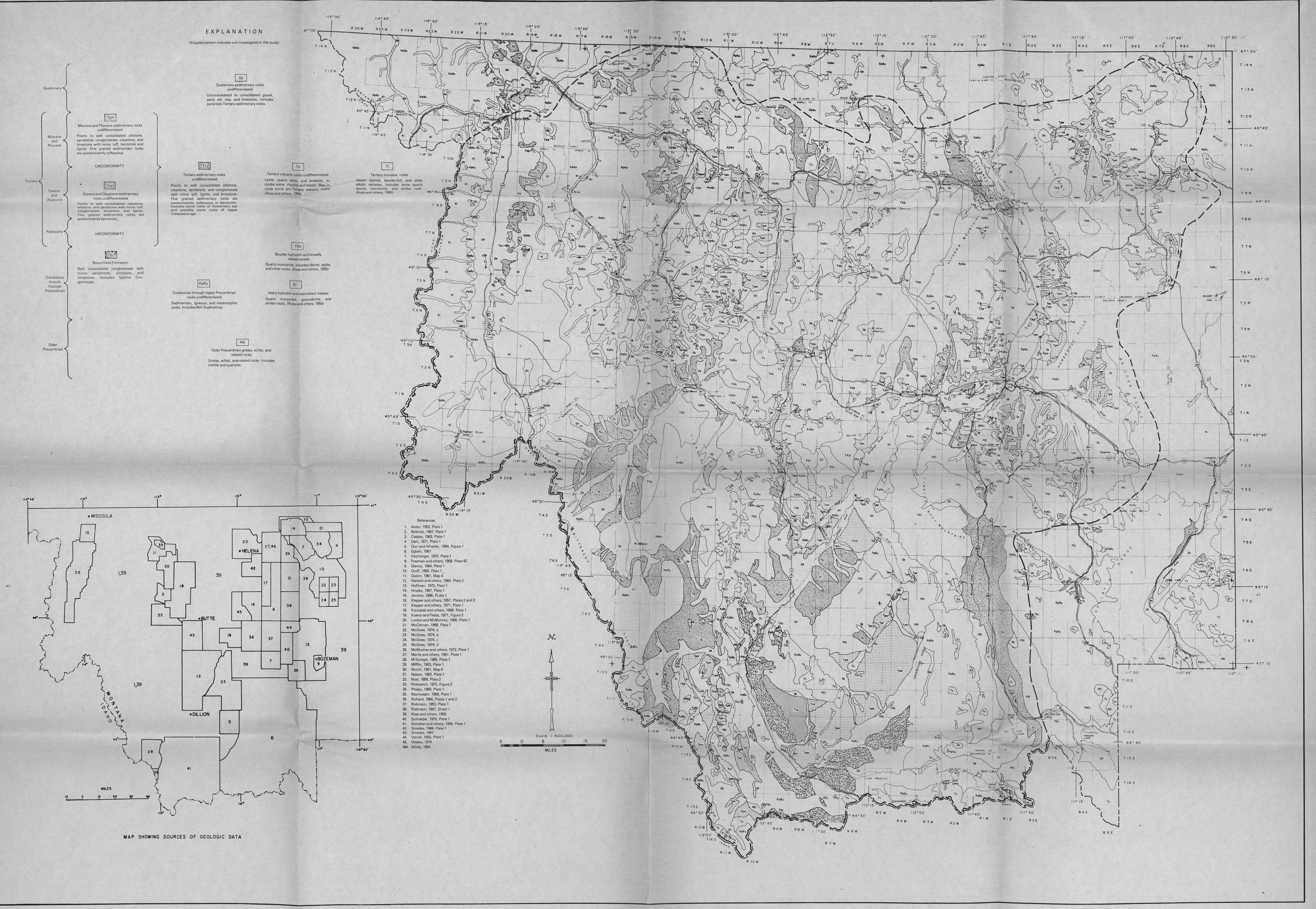





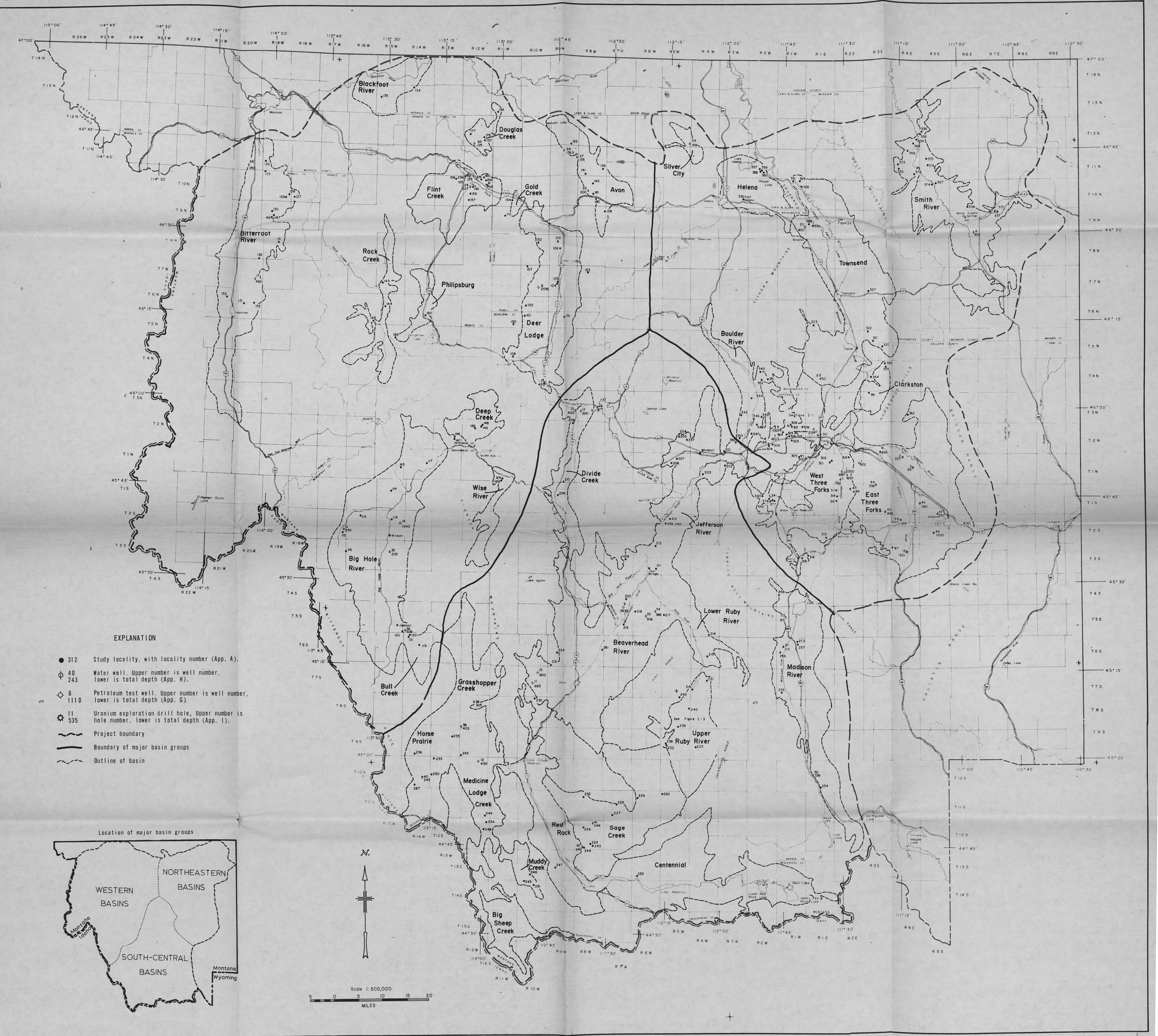




